\title{
Tradição Oral, Narrativa e Sociedade
}

\section{Waldemar Ferreira Netto}

https://doi.org/10.4322/85-99829-94-3

\section{Paulistana \\ - Editora}

São Paulo, 2017 
Copyright by Autor

Editora responsável

Adélia Maria Mariano da S. Ferreira

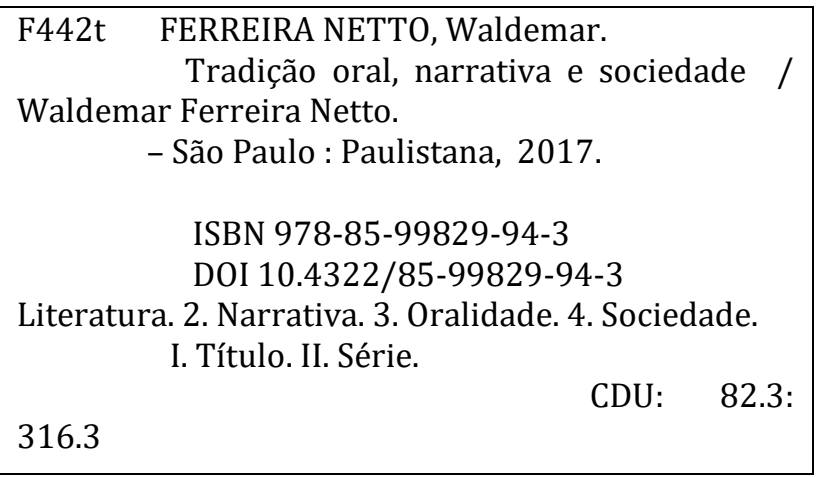

Índice para catálogo sistemático:

Maria José O. Souza CRB 8/5641

Literatura: 82

Narrativa: 82.3

Sociedade - Mudança Social: 316.3

Nenhuma parte desta publicação pode ser reproduzida ou transmitida por qualquer processo eletrônico, mecânico ou fotográfico, incluindo fotocópia, xerocópia ou gravação, sem a autorização prévia e escrita da Editora.

As informações desta publicação são de inteira responsabilidade do seu autor.

Todos os direitos desta edição reservados à

\section{Paulistana}

- Editora -

www.editorapaulistana.com.br

[2017] 


\section{SUMÁRIO}

Introdução .......................................................................... 1

Formação e mudança social ........................................... 9

Senso comum.....................................................................53

Individuação ....................................................................103

Formação simbólica ....................................................139

Narrativas......................................................................1

Algumas análises ...........................................................219

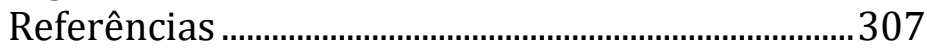

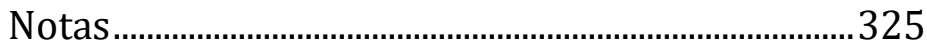

\section{ÍNDICE DE TEXTOS}

Texto 1: Ser Mãe................................................................ 81

Texto 2: A terra foi criada desta maneira ................. 96

Texto 3: Os homens sempre serão tristes se não fizermos alguma coisa.................................................... 98 Texto 4: Vindo da casa da pitanga (Lukas) ............184 Texto 5: Fui fazer ovo frito.............................................200 Texto 6: Fiz ovo mexido ................................................201

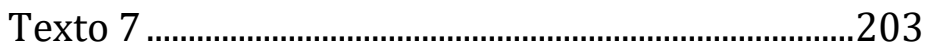

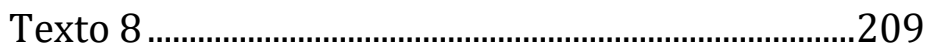

Texto 9: fragmento de "As relações com o Paí" ...211

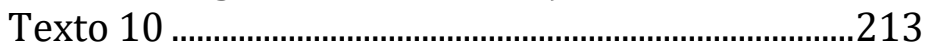

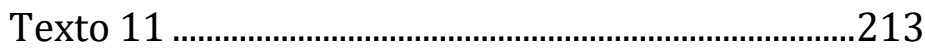

Texto 12: A cabeça sem corpo....................................219

Texto 13: 0 menino abandonado.................................232

Texto 14: Idn Kamni derruba a árvore Ye..............236

Texto 15: 0 mito do Sol.................................................241

Texto 16: A mãe das cobras...........................................250 
Texto 17: As relações com o Paí...................................253

Texto 18: Popoca ..............................................................26

Texto 19: O homem e a filha .........................................274

Texto 20: Os segredos da nossa casa..........................280

Texto 21: Como a língua sobreviveu aos dentes.284

Texto 22: É bom não ter cabeça ................................289

Texto 23: Aviso de mãe ..............................................294

Texto 24: A moedinha de cinquenta centavos e o repelente eletrônico........................................................300

Texto 25: Super-Homem................................................302 


\section{Introdução}

A análise de narrativas, no sentido mais extenso que esse termo pode assumir, tem recebido uma atenção cada vez maior nos últimos tempos. Um dos autores que mais fortemente contribuiu para isso foi Jerome Seymour Bruner (1915-2016), que deu argumentos convincentes para que a nossa própria identidade pudesse ser entendida como um fenômeno narrativo. Não há como decidir se essa hipótese é a definitiva, isto é, se tem uma correspondência exata com a realidade, mas é viável aceitá-la como plausível, sobretudo porque permite explicar um conjunto muito significativo de fatos sociais como se verá adiante. Por isso, este livro se pretende como uma introdução à análise de narrativas, especialmente voltada para os que se empenham nos estudos da linguagem.

Certamente que todos os leitores serão bem-vindos, mas muitos deles não encontrarão novidades aqui, ou ainda, não terão interesse nas novidades que encontrarem. Mesmo os que estudam a linguagem poderão não se interessar, porque a proposta é a de ser um livro introdutório voltado aos neófitos. Assim, há intenção de esclarecer conceitos e teorias conforme vão aparecendo nas discussões, supondo sempre que o leitor ainda não teve acesso a elas. Isso talvez tenha deixado a leitura um tanto cansativa, mas não havia como não fazer. 
O sentido mais amplo do termo "narrativa" é aquele que não diferencia as grandes obras literárias de quaisquer outras. ${ }^{1}$ Essas grandes obras são tomadas como apenas uma das possibilidades da expressão narrativa. Os grandes autores são os que se sobressaem dentre todos e, talvez por isso mesmo, sejam pouco representativos do homem comum. Assim como os medalhistas olímpicos, melhores do mundo, não podem ser tomados como estereótipos do cidadão comum, pode-se entender que os grandes escritores e suas grandes obras são justamente o que foge a esse padrão de normalidade. Isso, obviamente, não desmerece em nada suas obras; ao contrário, servem de meta, mas praticamente inatingível. Para que essa meta possa ser conhecida e admirada pela maioria, é importante que se torne um objeto de reflexão, que seja interpretada e difundida numa linguagem acessível à maioria. Jacques Le Goff (1924-2014) foi bastante esclarecedor quanto a isso.

Não foram as ideias de São Tomás de Aquino ou de São Boaventura que conduziram os espíritos, a partir do século XIII, mas nebulosas mentais, das quais ecos deformados de suas doutrinas, trechos empobrecidos, palavras malogradas sem contexto tiveram importância. ${ }^{2}$

São essas nebulosas mentais pairando sobre todas as cabeças e ilustrando-as - muitas vezes, equivocadamente - que formam os parâmetros para a autorreflexão social feita pelo homem comum. É essa autorreflexão do homem comum que interessa aqui, pois o contraste entre o que suas 


\section{Introdução}

narrativas preconizam e a realidade que ele experiencia será o motor de possíveis mudanças ou de conflitos não resolvidos

A concepção do livro baseia-se em partir do mais geral para o mais particular. Assim, a discussão parte da formação social, que é o conjunto maior, portador de todas as informações humanas, para o senso comum, que é exatamente o conjunto das informações que a sociedade procura manter; daí para a formação dos indivíduos, que são aqueles cujo conjunto reunido sob o mesmo senso comum forma a sociedade e, então, para a maneira particular como os indivíduos adquirem e portam esse conjunto simbólico, com que constroem a si mesmos e a sociedade. Finalmente aparecerão as narrativas e as suas possibilidades de abordagens que, conforme a hipótese inicial deste trabalho, serão a única base material para a compleição social. É bem verdade que outras bases podem se distinguir para isso, como o discurso científico ou o discurso jurídico, mas esses não serão objeto, senão muito tangencialmente, aqui.

Ainda que cada abordagem tenha seu início a partir das primeiras propostas teóricas, remontando à antiguidade clássica, isso deve ser interpretado somente como uma demonstração de como foi o nascimento da hipótese em questão. Essa abordagem histórica objetiva chamar a atenção do leitor neófito para o fato de que todas as ideias sempre têm uma outra bem parecida que a antecedeu e é bem possível, ainda, que as primeiras 
hipóteses tenham sido precedidas por outras não documentadas. Essa é uma informação perdida.

Seja como for que as primeiras hipóteses tenham aparecido, só sabemos das que chegaram até nós e são elas que nos interessam. E interessaram a todos. É obviedade dizer que todos os que discutiram as hipóteses que serão discutidas aqui também leram os que os antecederam. Assim, embora algumas das hipóteses possam não ter uma relação imediata entre si, elas formam uma cadeia de pensamentos que levou cada um dos outros a propor suas próprias teorias. Todos esses autores deveriam ser extremamente cultos e leitores contumazes. Não há nenhum motivo para pensar que eles todos não tiveram notícias mútuas de suas teorias. A citação e as referências exaustivas são algumas das benesses da modernidade. Mas isso não parece que era uma prática corriqueira até há muito pouco tempo. Provavelmente os autores pressupunham que todos os seus leitores eram cultos e leitores contumazes como eles mesmos; a rede de pensamentos formava-se automaticamente. Hoje, entretanto, não é assim, pois o volume de textos disponíveis para serem lidos é infinitamente grande. Atualmente, como bem definiu Gellner, vivemos num mundo de sensibilidades únicas, um mundo de especialidades e, por isso, vamos diretamente ao autor, ao artigo, ao número da página.

Para a formação social, a hipótese da diferenciação entre sociedades formadas por solidariedade mecânica e por solidariedade orgânica — respecti- 


\section{Introdução}

vamente aqui consideradas como sociedades tradicionais e sociedades modernas - de Durkheim, apresentadas em Da divisão do trabalho social, será a base de toda a discussão. A hipótese da diferenciação entre status adquirido e status atribuído de Ralph Linton, em seu livro $O$ homem. Uma introdução à antropologia, complementará a discussão. Essas hipóteses permanecerão ativas até a discussão final, na análise de narrativas. Vão perpassar a discussão do senso comum, da individuação e da formação simbólica.

Para a discussão sobre o senso comum, não haverá um texto base, mas sim um conjunto de obras de cunho antropológico. Essa hipótese, entretanto, vai culminar nas imagens de Gellner e de Mário de Andrade que apresentarão suas hipóteses da imersão do homem comum num sistema de crenças que lhe obscurece sua própria percepção da realidade.

Para a individuação, ainda que o ponto de partida sejam as ideias de Aristóteles, serão as ideias de David Hume que servirão de base para as discussões posteriores. George Mead servirá como ponto de passagem para a discussão de Gerard Genette, em relação à separação entre narrativa de ficção e as demais.

A formação simbólica, que é o capítulo em que finalmente a linguagem terá um papel predominante, terá como ponto de partida e base para todas as discussões, mesmo retroativamente, as ideias de 
Chales Sanders Peirce e Gottlob Frege. Serão suas concepções de símbolo que farão o enlace final de tudo o que se discutiu para, somente a partir delas, ter início a análise das narrativas.

Antes de falarmos das análises de narrativas, é importante ressaltar que a expressão "moderna" difere daquela que reclama o nome de Idade Moderna para o período histórico que tem seu início no final do século XVI. A modernidade a que se refere aqui tem seu início na revolução industrial cujas primeiras manifestações ocorreram no século XVIII, na Inglaterra, mas passariam a caracterizar boa parte do mundo ocidental somente a partir do século XIX. No Brasil, bem como em muitas partes do mundo pós-colonial, a industrialização em conjunto com a modernidade só ocorreria no início do século XX; e, mesmo assim, apenas parcial e pontualmente em algumas das grandes cidades desse momento, expandindo-se muito lentamente para outras regiões. Ainda hoje há um contraste acentuado em diversas regiões em que convivem sociedades tradicionais e sociedades modernas muito proximamente. 0 agronegócio, que promoveu a industrialização da zona rural, encostou nas fronteiras das sociedades tradicionais. Atualmente ambos competem pelo mesmo espaço.

0 fato que ora vai nos interessar, mais do que o contato, a fricção das fronteiras, é a superposição dessas duas características. A Tradição Oral manifesta pela internet nas redes sociais é, sem sombra de dúvida um fenômeno importante, mas o 


\section{Introdução}

que nos interessará será mais especificamente o conflito das tradições impressas nas mais diferentes narrativas sociais com a necessidade de implementação das novidades. Se vivemos sob o império da dimorfia sexual, da separação de raças por cor de pele ou de religião, da divisão entre divindades, profanidades e indiferença, e mesmo da desigualdade pela acumulação máxima e pela escassez absoluta de riquezas, dentre infinitas outras classificações humanas que podemos imaginar, tudo isso se esbarra e se manifesta nas formas narrativas como resultados de reflexões críticas que a sociedade faz sobre si mesma.

Procuraremos, então, além de apresentar alguns modelos de análise de narrativas, em geral, que estarão baseados nas propostas de Labov e Waletzky (1967), Labov (1997) e Bruner (1991), tentar estabelecer diferenças entre aspectos das narrativas que preconizem a descrição e a manutenção de comportamentos e os que preconizem a inovação pela reflexão crítica do comportamento tradicional.

$\mathrm{Na}$ medida em que o estabelecimento de papéis sociais é extremamente diversificado em relação às sociedades que estabelecem suas narrativas, também esse aspecto será considerado.

Sempre que possível, tentamos colocar todas as citações em seu formato original, quando estavam em português, ou, se estivesse em outra língua, procuramos traduções ou nós mesmos as tradu- 
zimos, deixando o original disponível nas notas apresentadas no final. Entretanto, nem sempre foi possível encontrar ou apresentar o original, sobretudo quando era numa língua que não conhecemos; estiveram nessa situação os textos de Humboldt, Frege, Freitag, Pavlov, Propp, Wertheimer. Ainda houve casos em que só conseguimos nos valer de traduções, como a tradução espanhola de Humboldt, a inglesa de Freitag e de Wertheimer, a portuguesa de Propp, por exemplo. 


\section{Formação e mudança social}

A criação de hipóteses sobre a mudança social, bem como sobre a própria formação das sociedades é fato que ocorre desde os mais longínquos tempos gregos. Aristóteles entendia que a sociedade era uma composição de subagrupamentos humanos. ${ }^{3}$ Segundo ele, várias famílias formariam um povoado ou uma aldeia quando suas necessidades iam além daquelas mais corriqueiras; vários povoados formariam uma comunidade; várias comunidades formariam uma cidade.

No entanto, a ideia aristotélica de sociedade ia bem além disso. A sociedade era entendida como algo que ultrapassava a esfera do indivíduo e das suas formações mais particulares, como clã e a família. A sociedade manifestava-se num nível superior, como o conjunto inseparável de todas essas instâncias. Para ele, além de preexistir ao indivíduo, a sociedade não dependeria de seus membros, tomados isoladamente. 0 inverso, entretanto, não seria verdadeiro. Cada um dos indivíduos seria sempre dependente da comunidade ou da cidade, sendo essa uma das características que o diferenciariam dos deuses e dos animais. Desse ponto de vista, Aristóteles propunha que o ser humano era essencialmente social.

Essas posições de Aristóteles vão servir de base para muitas discussões sobre a formação das sociedades 
- como a de um conjunto de comunidades, bem como dessa condição humana essencialmente social - que se farão durante muitos séculos, quiçá, até muito recentemente, com muito poucas variações. ${ }^{4}$

Argumentando em relação a isso, Aristóteles, citando a Odisseia de Homero, estabeleceu um início para a formação social dos tempos primitivos em que se viveria em famílias dispersas, como os Ciclopes, sem formar comunidades. Mas a sistematização da mudança social iria ocorrer somente a partir do século XVIII, com Jean-Antoine-Nicolas de Caritat, marquis de Condorcet (1743-1794). O autor imaginava dez estágios sucessivos de desenvolvimento social. 0 primeiro deles assemelhava-se à descrição que faz Aristóteles quando trata das aldeias.

0 primeiro estado de civilização em que se tenha observado a espécie humana é aquele de uma sociedade pouco numerosa de homens subsistindo da caça e da pesca, conhecendo apenas a arte grosseira de fabricar suas armas e alguns utensílios domésticos, de construir ou de escavar habitações, mas tendo já uma língua para comunicar suas necessidades, um pequeno número de ideias morais, das quais eles deduzem regras de conduta comum, vivendo em famílias, conformando-se a usos comuns que lhes fazem as vezes de elites e tendo até uma forma grosseira de governo. ${ }^{5}$

Condorcet (2009) acreditava na evolução do homem primitivo ao homem europeu, especialmente o europeu. Diferentemente de Aristóteles que buscava 


\section{Formação e mudança social}

o homem primitivo dentre as descrições míticas dos ciclopes homéricos, para Condorcet, a associação entre povos primitivos - os primeiros homo sapiens - e os povos com os quais os viajantes dos séculos $\mathrm{XV}$ e XVI tinham entrado em contato era demasiadamente tentadora para não ser levada em consideração. Sua hipótese era a de que os povos descritos pelas narrativas seiscentistas ainda estariam na primeira etapa.

Na primeira, em que as narrativas dos viajantes nos mostram o estado da espécie humana nos povos os menos civilizados, estamos limitados a adivinhar por quais degraus o homem isolado, ou antes limitado à associação necessária para se reproduzir, pôde adquirir esse grau de aperfeiçoamento cujo último termo é o uso de uma linguagem articulada. ${ }^{6}$

Essa hipótese de que os povos indígenas das Américas, ou os aborígenes da Oceania, ou os negros da África, dentre outros, seriam remanescentes dos povos primitivos persistiu em praticamente todas as discussões sociológicas e antropológicas do século XIX e, possivelmente, persiste para muitos até hoje. Assim como a ideia de que o europeu seria o ápice dessa evolução. ${ }^{7}$

Não há como se sustentar essa hipótese com nenhum argumento, uma vez que todos os povos existem desde o mesmo momento. Obviamente todos passaram por mudanças decorrentes tanto do intercurso que tiveram com o ambiente como do contato entre eles, mas somente alguns as deixaram registradas. No entanto, a hipótese do evolu- 
cionismo social de Condorcet (2009) obscureceu quaisquer outras interpretações possíveis, até que a virada para o século XX se concretizasse. Claude Levi-Strauss (1908-2009) foi um dos autores que mais fortemente se opuseram ao evolucionismo social. ${ }^{8}$ Numa passagem que já citei alhures, ${ }^{9}$ mas que pode ser retomada no contexto de nossa discussão, ele chama a atenção para o fato de que não haveria sociedades em diferentes etapas de desenvolvimento, uma vez que todas teriam a mesma idade. De forma bem-humorada ele lembrou que a diferença entre as sociedades é que algumas teriam escrito seus diários de infância e de adolescência e outras, não. ${ }^{10}$

A ideia de evolução como um fenômeno orientado do mais imperfeito para o mais perfeito presente no evolucionismo social de Condorcet também se fez presente no evolucionismo biológico de Jean Baptiste de Monet, chevalier de Lamarck (1743-1794). Para este, os seres mais simples seriam também os mais imperfeitos e os mais complexos, ou com organização mais composta, os mais perfeitos. ${ }^{11}$ Obviamente, os seres mais perfeitos seriam os humanos.

Essa hipótese de evolução em que seres mais imperfeitos estariam na ponta mais distante e no início do processo seria facilmente retomada a partir da proposta de Condorcet. Os povos primitivos, nesse processo evolucionário, eram os mais imperfeitos e os europeus os mais perfeitos. Willhelm von Humboldt (1767-1835), por exemplo, 


\section{Formação e mudança social}

estabeleceu uma sequência natural para a evolução das línguas - aglutinantes, isolantes e flexivas, nessa ordem - que se caracterizava pela priorização da sintaxe. ${ }^{12}$

Sua hipótese era a de que a sintaxe marcada na flexão seria a forma própria do raciocínio analítico evoluído. As formas aglutinantes, como ele falava da língua mexicana, caracterizariam a origem da linguagem humana. Segundo ele, essa língua original confundiria palavra e frase, na medida em que o conteúdo de uma frase poderia se expressar por meio de uma só palavra, cuja formação morfológica aglutinante daria conta do sentido completo. Nas línguas flexivas, segundo ele, mais adequadas ao pensamento analítico do homem evoluído, do homem civilizado e racional, os sentidos que se acumulavam numa só palavra nas línguas aglutinantes seriam mais propriamente interpretados analiticamente, dado o caráter abstrato que eles teriam, inacessível pela aglutinação. ${ }^{13}$

Isidore Auguste Marie François Xavier Comte (1778-1857), coevo a Humboldt, fazia proposta semelhante. Para ele, a humanidade, na sua evolução se desenvolveria também do ponto de vista de suas próprias concepções de mundo, a partir de um pensamento primitivo até o pensamento que ele chamou de positivista. 0 pensamento primitivo envolveria a crença no sobrenatural. Em sua primeira fase, a teológica, seria inicialmente fetichista, depois politeísta e, finalmente, monoteísta. Em seguida, na segunda 
fase, a metafísica, a crença no sobrenatural seria abandonada, partindo para a busca das verdades diretamente na natureza. Segundo ele, esta fase não seria nada mais do que a simples modificação geral da primeira, em que agentes sobrenaturais se substituiriam por forças abstratas, entidades (abstrações personificadas) inerentes aos diversos seres do mundo, e concebidas como capazes de engendrar por elas próprias todos os fenômenos observados, cuja explicação consistiria, então, em determinar para cada um uma entidade correspondente. ${ }^{14} \mathrm{~A}$ terceira fase, a positiva, seria então a definitiva.

Enfim, no estado positivo, o espírito humano, reconhecendo a impossibilidade de obter noções absolutas, renuncia a procurar a origem e o destino do universo, a conhecer as causas íntimas dos fenômenos, para preocupar-se unicamente em descobrir, graças ao uso bem combinado do raciocínio e da observação, suas leis efetivas, a saber, suas relações invariáveis de sucessão e de similitude. A explicação dos fatos, reduzida então a seus termos reais, se resume de agora em diante na ligação estabelecida entre os diversos fenômenos particulares e alguns fatos gerais, cujo número o progresso da ciência tende cada vez mais a diminuir. ${ }^{15}$

Mas será com Herbert Spencer (1820-1903) que a analogia entre a evolução biológica e a evolução social será mais radicalizada. Spencer definiu a evolução, ou progresso, como ele fala: 


\section{Formação e mudança social}

Está fora de qualquer discussão o fato de o progresso orgânico consistir na passagem do homogêneo para o heterogêneo.

Assim, propomo-nos demonstrar, em primeiro lugar que esta lei do progresso orgânico é a lei de todo o progresso; quer se trate das transformações da terra, do desenvolvimento da vida à sua superfície ou do desenvolvimento das instituições políticas, da indústria, do comércio, da língua, da literatura, da ciência, da arte, dá-se sempre a mesma evolução do simples para o complexo, mediante sucessivas diferenciações. Desde as mais remotas transformações cósmicas, de que ainda existem sinais, até aos mais recentes resultados da civilização, vê-se que o progresso consiste essencialmente na passagem do homogêneo para o heterogêneo. ${ }^{16}$

Ora, dessa definição, obviamente baseada nas proposições de Lamarck, para a manutenção da hipótese de que os povos autóctones das Américas, da Oceania e da África não estariam sequer no início do desenvolvimento social, não havia dificuldade:

Como se observa nas tribos bárbaras atuais, a sociedade, nas suas formas mais primitivas e inferiores, é um agregado homogêneo de indivíduos que têm o mesmo poder e exercem idênticas funções: a única diferença observada nesta última é a que acompanha a diferença de sexos. Todos os homens são guerreiros, caçadores, pescadores, fabricantes de utensílios, construtores; todas as mulheres se ocupam em iguais serviços; cada família se basta a si mesma, e, fora dos casos de agressão ou de defesa, pode viver aparte das demais. ${ }^{17}$ 
Ernest André Gellner (1925-1995) chamou a atenção para o fato de que essa tendência do evolucionismo social tenha se tornado argumento para a divisão hierárquica das nações. Ao criticar a discussão teórica de James George Frazer (1854-1941) quanto às diferentes etapas da do pensamento humano, ${ }^{18}$ Gellner afirmou o seguinte:

0 aspecto evolucionário do darwinismo, a ênfase na continuidade da evolução, tornaram pelo menos plausível a suspeita de que os povos pré-instruídos sobreviventes poderiam servir para ilustrar a situação dos povos primitivos do passado, a cuja organização social seria de outro modo extremamente complicado aceder. A esperança no estabelecimento de uma descrição evolucionária para a evolução humana era tentadora, e é evidente que tinha implicações filosóficas e políticas: o padrão da evolução poderia proporcionar um mapa para a hierarquização do poder num mundo dominado por uma nova espécie de império, territorialmente descontínuo, em que os detentores do poder pareciam viver numa "fase" diferente da evolução social relativamente aos que eram governados. ${ }^{19}$

Apesar de a associação entre o homem primitivo e os povos autóctones permanecer como característica do século XIX, na virada para o início do século XX, diversos pensadores formularam hipóteses sobre a formação e o funcionamento das sociedades humanas, que, mesmo hoje, dificilmente são contestadas. Temos Karl Marx (1818-1883), Karl Emil Maximilian Weber (1864-1920), Franz Uri Boas (1858-1942), dentre alguns outros, cuja obra 


\section{Formação e mudança social}

continua sendo referência para os estudos a respeito das sociedades. Interessa-nos aqui as hipóteses estabelecidas por David Émile Durkheim (1858-1917), na sua obra Da divisão do trabalho social.

Muito tempo depois de Aristóteles, mas certamente baseado em sua proposta, já no final do século XIX, Durkheim (2014) propôs que um fato social seja "toda maneira de fazer, suscetível de exercer sobre o indivíduo uma coerção exterior; ou ainda, toda maneira de fazer que é geral na extensão de uma sociedade dada e, ao mesmo tempo, possui uma existência própria, independentemente de suas manifestações individuais". ${ }^{20}$ A proposição de fato social como algo que possui existência própria e é exterior ao indivíduo - devendo ser tratada como uma coisa, ${ }^{21}$ nas palavras de Durkheim - vai exatamente ao encontro da proposição de Aristóteles a que já nos referimos.

A hipótese de mudança social de Durkheim fundava-se na intensificação do contato social que decorreria de movimentos imigratórios de grande porte. Ele entendia que as sociedades eram fatos sociais - pré-existentes, portanto, aos indivíduos que as compunham - que se organizavam segundo dois tipos de solidariedade entre os indivíduos: a similaridade e a complementaridade. 0 primeiro formaria a solidariedade mecânica e o segundo, a orgânica. No caso da solidariedade mecânica, formada pela similaridade entre os indivíduos, haveria uma menor variedade de comportamentos; 
a sociedade estabeleceria, por si só, as funções necessárias para seu funcionamento. A coesão da sociedade se formaria principalmente pelas relações de parentesco e pela transmissão de conhecimento tradicional, isto é, oralmente do mais velho para o mais novo. Essa forma de transmissão oral do conhecimento, atualmente tratada como Tradição Oral, geraria uma maior igualdade entre os membros do grupo, criando uma forte noção de grupo, tendendo à igualdade entre o coletivo e o individual, noutros termos, eu=nós. ${ }^{22} \mathrm{~A}$ sociedade formada por solidariedade mecânica preconizaria, portanto, o conjunto dos indivíduos como um único bloco, em que qualquer opinião ou desejo individual equivaleria à opinião ou ao desejo da coletividade. De forma bastante radical, o autor chegou a propor que nessas sociedades a individualidade simplesmente não existiria. ${ }^{23}$ Para o autor, essas sociedades formariam um bloco coeso pela similitude de suas crenças, e padrões comportamentais de maneira que as fronteiras entre as sociedades seriam marcadas fortemente pela impermeabilidade e pelo isolamento. ${ }^{24}$ E, para usar a expressão de Lévi-Strauss anos depois, para além de suas fronteiras, terminaria a humanidade. ${ }^{25}$

Mesmo que as sociedades formadas por similitude pudessem se caracterizar pela impermeabilidade nas fronteiras, isso não significava dizer que tais sociedades não vissem seus vizinhos, mas sim que se diferenciariam em relação a eles. Como tais fronteiras também seriam fatos sociais, seriam 


\section{Formação e mudança social}

igualmente passíveis às mudanças, conforme fossem as necessidades. 0 contato entre as fronteiras ocorreria em aspectos culturais específicos que, apesar de provocarem mudanças, não transformariam a sociedade em seu conjunto, como veremos mais adiante.

Tendo como ponto de partida a sociedade formada pela similitude, Durkheim propôs que poderia ocorrer uma mudança nesse tipo de sociedade: seria a reconfiguração da solidariedade mecânica para a solidariedade orgânica, isto é, do vínculo social por similitude para o vínculo social por complementaridade. No caso da solidariedade orgânica, a formação social seria diferente. Ainda que fosse decorrência de uma sociedade formada por solidariedade mecânica, sua formação viria do contato entre essas sociedades, por conta da permeabilização das fronteiras e, portanto, do aumento do fluxo migratório de pessoas e de informação. $\mathrm{Na}$ medida em que o deslocamento entre as fronteiras dos grupos se intensificaria, as trocas de informação também se intensificariam trazendo para dentro da sociedade novas crenças, novos comportamentos, novos desejos. Com isso, aumentaria também a divisão do trabalho, na medida em que se desencadeariam novas pressões de sentimentos e de necessidades sociais. ${ }^{26}$ Essa divisão do trabalho é o que caracterizaria as sociedades formadas pela solidariedade orgânica. Porque seria justamente a complementaridade das atividades exercidas pelos membros da sociedade que estabeleceria sua 
própria coesão. Nesse ponto, Durkheim retomou a hipótese de Comte de que seria "a divisão contínua dos diferentes trabalhos humanos que constitui principalmente a solidariedade social, e que é a causa elementar da extensão e da complicação crescente do organismo social...". 27

A divisão do trabalho procedente do aumento e do adensamento populacional e, consequentemente, da maior troca de informações acarretaria mudanças no comportamento dos indivíduos que formariam a sociedade. Porque diferentes pessoas atuariam de forma diferente e complementar a seus pares, haveria um conjunto de comportamentos sociais cada vez mais variado e, portanto, diferente atribuição de valores e de julgamentos a esses novos comportamentos.

Uma sociedade moderna além de criar maior heterogeneidade cultural entre seus membros geraria, também, maior dependência, na medida em que as necessidades de uns teriam de ser supridas por outros. Gilberto Velho (1945-2012) chamou esse tipo de sociedade de "sociedade complexa" e a definiu como

Uma sociedade na qual a divisão social do trabalho e a distribuição de riquezas delineiam categorias sociais distinguíveis com continuidade histórica, sejam classes sociais, estratos, castas. Por outro lado, a noção de complexidade traz também a ideia de heterogeneidade cultural que deve ser entendida como a coexistência, harmoniosa ou não, de uma pluralidade de 


\section{Formação e mudança social}

tradições cujas bases podem ser ocupacionais, étnicas, religiosas, etc. ${ }^{28}$

Sob vários pontos de vista, a proposta de Velho complementa a divisão feita por Durkheim. Ao propor que sociedades modernas resultem da interpenetração de várias sociedades, o caráter tradicional de cada uma delas permaneceria na sociedade resultante, de forma "harmoniosa ou não", impondo o convívio de comportamentos tradicionais arraigados entre os membros do grupo. Não se trataria, portanto, de uma heterogeneidade cultural temporária com tendências entrópicas, isto é, que se harmonizariam pelo convívio no correr do tempo, mas a manutenção e a incorporação das diferenças teriam de ser administradas por algum ou alguns dos membros dessas próprias tradições.

Seguindo de perto a proposta aristotélica de que o ser humano precisaria viver em sociedade, por não ser deus nem fera, Durkheim propôs que a diferença entre homens e animais decorreria do aparecimento de fatos sociais. Para ele, os fatos sociais criariam e desenvolveriam os fatos psíquicos, ou seja, seria o fato de viver em sociedade que criaria relações afetivas entre os indivíduos e não o oposto. ${ }^{29} 0$ argumento de Durkheim para corroborar sua hipótese era o de que as relações afetivas entre pai e filho tal como são conhecidas - ao que parece, em sua própria sociedade - adviriam de um tipo específico de relação de parentesco, pois, noutras sociedades, cujo tipo de relação de parentesco fosse diferente, outras relações afetivas se manifestariam. 
Em que pese o fato de Durkheim, como homem do século XIX, associar os povos autóctones das Américas, da África e da Oceania ao primitivo algumas páginas antes, ele afirmava que foi a mudança social, de solidariedade mecânica para orgânica, que fez a diferença entre o selvagem e o civilizado, ou, da "sensibilidade confusa" do primitivo para a "faculdade de ideação" —, o autor já esboçava um princípio de relativismo social, tirando as diferenças étnico-sociais do jugo exclusivo da evolução. Apesar de ele não ir muito longe nisso, como o faria posteriormente Cliffort James Geertz (1926-2006), ${ }^{30}$ Durkheim deu condições para novas formas de reflexão sobre isso. Em relação ao exemplo, advém a dúvida relativa a quais seriam o os instrumentos culturais geradores do "amor paterno" ocidental.

Ainda nessa mesma linha de raciocínio pré-relativista cultural, Durkheim não parecia ser muito otimista com os resultados da mudança social. Ele entendia que a civilização não era uma "finalidade que move os povos pela atração que exerce sobre eles," 31 mas uma necessidade imposta aos homens "porque não há para eles outra maneira de viver nas novas condições em que estão colocados". ${ }^{32}$ Desse ponto de vista, o progresso tecnológico em várias áreas seria "útil ou, pelo menos, utilizado", mas seria, principalmente, um ajuste, uma correção que repararia as perdas causadas por ele mesmo. ${ }^{33}$ Durkheim inverte, dessa forma, os sinais do processo de mudança social, tratando as sociedades 


\section{Formação e mudança social}

modernas como resultados de um desequilíbrio social, por romper a homeostase das sociedades tradicionais, como se verá mais adiante.

Durkheim ainda modalizou suas posições mais extremadas na relação que procurara estabelecer entre homem e sociedade. Ele mesmo considerou exagerado dizer que a vida psíquica só começaria com a social. ${ }^{34}$ Para ele, a vida psíquica adquiriria extensão e atuaria mais intensamente nos "terrenos que o instinto deixou de ocupar ou, então, aqueles em que ele não pode se estabelecer". ${ }^{35}$ Embora o autor não tenha dado exemplos desses instintos e dos espaços em que não se estabeleceriam, sua hipótese permitiria interpretar o homem do ponto de vista social e biológico, seja quanto às integrações que o caracterizassem, seja quanto aos conflitos que o incomodassem.

Apesar de as oposições teóricas adotadas por Durkheim não mostrarem coerência absoluta, são imprescindíveis para a compreensão da maioria das discussões que se farão posteriormente sobre as mudanças sociais. 0 primeiro aspecto que devemos ressaltar aqui de suas propostas é o encadeamento de dois tipos básicos de sociedade: o que se formou por similitude, o da solidariedade mecânica, e o que, decorrente deste, se formou por complementaridade, o da solidariedade orgânica. Às sociedades do primeiro tipo, convencionou-se chamar por sociedades tradicionais; enfatizando, como se verá, seu traço mais característico de transmissão de conhecimento dos mais velhos para os mais novos. 
Às sociedades do segundo tipo convencionou-se chamar por sociedades modernas. ${ }^{36}$

Ao estabelecer esses dois tipos de sociedade, em que a moderna seria decorrência da tradicional, ele também não eliminou a possibilidade de sua coexistência. ${ }^{37}$ Podemos entender que, para ele, seriam dois conjuntos de forças em sentido contrário, quais sejam, a consciência coletiva das sociedades tradicionais que conflitaria a todo tempo com a consciência individual das sociedades modernas. Essa hipótese nos permite ainda entender que a supressão de uma dessas forças contrárias provocaria a reconfiguração total das sociedades humanas, tal como as conhecemos. Assim, embora uma pressão atuante mais forte ou mais fraca em um ou em outro sentido possa ser prevista, não há que se imaginar, a partir dessa proposta, que uma dessas pressões pudesse desaparecer completamente. Assim, uma sociedade nunca seria totalmente moderna ou totalmente tradicional.

Durkheim propôs que três fatores pudessem ocorrer para forçar o desequilíbrio dessas pressões contrárias: as variações das condições de vida, que não seriam as mesmas em toda parte; a perda da autoridade das tradições pelo contato intersocietal e, finalmente, a diminuição do controle coletivo sobre o indivíduo.

0 primeiro desses fatores dizia respeito à consequência da expansão territorial, do aumento 


\section{Formação e mudança social}

populacional e das variações ambientais e culturais que, tomados juntos ou separados, desencadeariam experiências pessoais diversificadas, que não seriam compartilhadas pelo grupo. Dessa maneira, haveria um crescimento da consciência individual em detrimento da coletiva, que teria de contentar-se, para manter a unidade, ou com generalizações ou com um conjunto cada vez menor de informações comuns a serem transmitidas.

0 segundo fator decorreria diretamente desse primeiro, na medida em que diria respeito à manutenção da tradição como fonte principal do conhecimento. As novas experiências pessoais adquiridas pelo contato com novos ambientes e novas culturas não teriam mais como seguir os preceitos tradicionais, tanto porque estes perderiam seu alcance sobre os novos fatos, isto é, não teriam mais a eficácia de outrora; como porque a expansão territorial e populacional exigiria a sua substituição.

0 terceiro fator envolveria exatamente a possibilidade de os novos conhecimentos adquiridos poderem ser efetivamente aplicados. Desse ponto de vista, o que estava em jogo era a liberdade individual como decorrência tanto da expansão territorial e populacional quanto da substituição do conhecimento tradicional pelo moderno.

Segundo Durkheim, o controle social sobre o comportamento individual perderia sua força e as inovações sociais poderiam ser efetivamente 
aplicadas, seja por conta da distância física entre os indivíduos seja por conta do aumento numérico dos mesmos. Com isso, podemos imaginar que o reforço contrário a esses três fatores - i) a promoção da experiência coletiva, ii) a manutenção das tradições e iii) o controle da aplicação das inovações atuaria no sentido de aumentar a pressão da consciência coletiva de maneira a evitar o domínio da consciência individual.

Como pudemos ver até agora, ao se verificarem as condições necessárias para a mudança social, que transformaria sociedades tradicionais em modernas, se desencadearia uma mudança profunda no conjunto dos conhecimentos, crenças e padrões comportamentais que garantiam a própria similitude dos membros formadores da sociedade. Esta mudança provocaria, por sua vez, não só a divisão do trabalho social, como também o processo de individuação característico da sociedade moderna.

Ralph Linton (1981) chamou aos diferentes padrões comportamentais que ocorrem numa sociedade de status e papéis. A noção de status compreenderia o conjunto de deveres e direitos de um indivíduo em uma sociedade. A noção de papel compreenderia a efetiva realização do status numa sociedade. De maneira bastante grosseira, podemos dizer que o status seria o rótulo que se atribuiria aos papéis a serem desempenhados na sociedade. Os papéis, por sua vez, se caracterizariam por se tratar de um conjunto de conhecimentos, crenças e padrões comportamentais que se esperaria que fossem 


\section{Formação e mudança social}

realizados pelos indivíduos que tivessem o status correspondente a eles. Podemos entender, portanto, que as informações referentes ao desempenho dos papéis fariam parte da competência dos membros de uma sociedade. Logo, tais competências teriam de ser adquiridas socialmente quer seja por meio de um ensinamento formal ou não. Seja como for, os membros da sociedade teriam de saber como pensar e agir antes de fazê-lo.

Ainda conforme a proposta de Durkheim, nas sociedades tradicionais, essa transmissão de crenças e de conhecimentos ocorreria, especialmente, pelo intercurso das gerações mais velhas com as mais novas. Desse ponto de vista, seriam tratadas institucionalmente como fatos sociais, que sobre-existem aos membros do grupo. É o caso, por exemplo, das relações de parentesco. Se o status pai ou o status mãe é comum às sociedades, as regras estabelecidas pelas diferentes sociedades implicam em diferenças comportamentais bastante variáveis. Nesse caso particular, as relações de parentesco envolvem diferentes categorizações que, por sua vez, promovem diferentes relacionamentos entre as portadoras desses status. Se entre nós, como fato social, a irmã da mãe é tia, entre grupos da família linguística tupi-guarani essa não é uma categorização válida, sendo a mãe e a irmã da mãe ambas categorizadas pelo mesmo parentesco. Essa categorização gera, entre eles, deveres e direitos ao marido que, eventualmente, tem de assumir as duas como esposa, tendo a obrigação de sustentá-las e de 
protegê-las. ${ }^{38}$ Nesse caso, ainda que o status vá rotulado linguisticamente, o papel tem de ser conhecido pela própria tradição.

Linton (1981) propôs também que os status pudessem ser atribuídos pela sociedade ou adquiridos pelos indivíduos. Os status atribuídos decorreriam tanto do próprio nascimento e de suas relações de parentesco - as categorizações de homem, mulher, filho, irmã, etc. - como de fatores decorrentes do crescimento do indivíduo no interior do grupo - as categorizações de esposa, pai, criança, velho, etc. Os status adquiridos dependeriam das aptidões do indivíduo. Nesse caso, teriam de ser escolhidos e pressuporiam um esforço pessoal para sua aquisição - é o caso de cacique, curandeiro, contador de história, etc. Qualquer pessoa poderia se declarar cacique ou curandeiro, mas seu status só seria reconhecido pelo grupo se ele de fato fosse capaz de desempenhar esses papéis, isto é, se fosse capaz de exercer a liderança do grupo e de curar os doentes.

Se conjugarmos a proposta de Linton (1981) quanto à noção de status e papel com a da divisão do trabalho social feita por Durkheim (1999) que discutimos acima, verificaremos que são complementares entre si. Quanto maior for a divisão do trabalho tanto mais numerosos seriam os papéis a serem desempenhados. Numa sociedade tradicional, em que a divisão do trabalho social é tímida e tem um alcance limitado, não haveria porque se esperar uma multiplicação dos papéis a 


\section{Formação e mudança social}

serem desempenhados. Como os status são em número pequeno e são transmitidos pela tradição, se caracterizariam por serem em sua grande maioria status atribuídos, deixando pouca margem para o esforço individual dos status adquiridos. Disso decorre que, não se exige esforço dos membros da sociedade para a sua atuação social senão nos raros casos em que se tenha que lidar com papéis adquiridos. Pode-se entender que, nesse caso, é a própria sociedade que atua atribuindo funções para seus membros de tal maneira que, enquanto permanecerem as condições externas em que a sociedade se encontra, seus membros poderão desempenhar suas atividades sociais quase automaticamente.

Diferente é o caso da sociedade moderna em que, ao contrário, há predomínio de status adquiridos. Nessa sociedade, seus membros são levados a uma participação intensa, dispendendo uma energia muito maior para a sua atuação social. A divisão do trabalho, por sua vez, exige a seleção de status que, superpostos no mesmo indivíduo, criam um conjunto praticamente exclusivo para cada um. Essa quebra de homogeneidade de comportamentos implica, por sua vez, a quebra da sensação de coletividade, promovendo uma das diferenças mais significativas entre esses dois tipos de sociedades, que é a criação da individualidade: euキnós. 


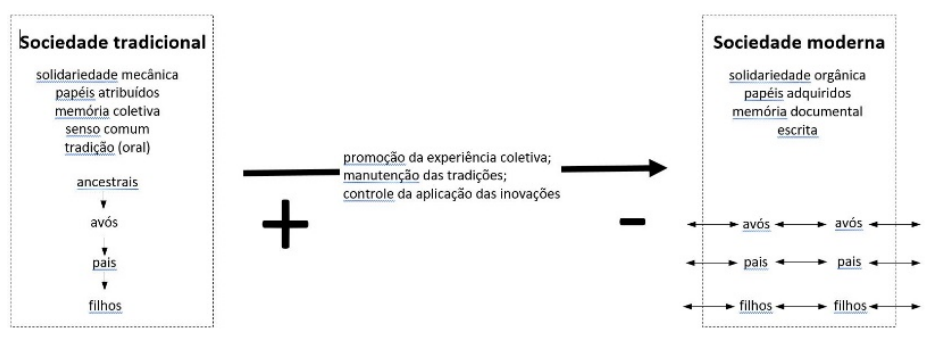

Na figura acima, tentei mostrar características de cada tipo dukheimiano de sociedade: à esquerda, a formada por similitude, ou solidariedade mecânica, à direita, a formada por complementaridade ou solidariedade orgânica. A formação social por similitude, própria das sociedades tradicionais, se caracteriza pela predominância de status atribuídos, memória coletiva e transmissão tradicional (vertical, marcada com setas verticais) de conhecimento. Na medida em que a atribuição de status é um procedimento que decorre da submissão das novas gerações à memória coletiva que lhes transmitem os mais velhos, criando uma situação de homeostase, a coesão social se dá, no eixo vertical, pela aceitação desses status, o que evita o conflito entre gerações, e pelo compartilhamento entre os pares das informações herdadas, o que evita a desigualdade, no eixo horizontal. A formação por complementaridade, característica das sociedades modernas, se caracteriza pela predominância de status adquiridos, de memória individual e transmissão de conhecimento pelos pares (horizontal, marcada com setas horizontais). Como 


\section{Formação e mudança social}

a mudança proposta é decorrente da permeabilidade da fronteira social, os novos membros da sociedade trazem consigo novos status que independem da tradição da sociedade receptora. Novos comportamentos, assuntos e emoções passam a integrar as práticas cotidianas tradicionais, não sem algum conflito. A informação disponível às novas gerações difere daquela tradicional que era conferida pelas gerações anteriores.

A individuação é consequência desse processo. Assim, se nas sociedades tradicionais predominava o homem pronto, capaz de atuar sozinho em quase todas as áreas da sociedade, nas sociedades modernas a especialização impede essa multiplicidade individual de funções. Desse ponto de vista, os indivíduos modernos dependem muito mais de seus pares do que os indivíduos tradicionais. Olhando a nossa volta, é fácil notar que a divisão do trabalho social é realmente significativa, se comparada com as das sociedades tradicionais. Numa lista de profissões do Fundo de Amparo ao Trabalho do Ministério do Trabalho ${ }^{39}$ é possível localizar mais de 10.700 itens que atualmente discriminam diferentes atuações sociais, no trabalho profissional. Somadas essas atuações profissionais aos muitos variados status adquiridos que um indivíduo pode suportar, a combinatória cria um conjunto quase exclusivo para cada indivíduo. Dificilmente poderíamos arrolar todos os status e descrever todos os papéis 
correspondentes de uma sociedade moderna. Assim que terminássemos uma lista, outros status teriam sido criados e muitos papéis teriam sido reformulados. Trata-se de um processo dinâmico que, no entanto, desenvolveu-se de forma gradual. Temos, portanto, que entender tanto essa mudança como a criação de status e a reformulação dos papéis.

No centro da figura, tentei representar os fenômenos cuja participação mais ou menos ativa provoca a mudança de uma sociedade formada por similitude numa formada por complementaridade. Conforme já vimos, sentimento de coletividade, ênfase na tradição e rejeição às inovações atuam no sentido contrário ao da formação de uma sociedade moderna. A possibilidade massiva de novas experiências individuais, a independência das tradições como fonte única do conhecimento e a liberdade para a aplicação das inovações seriam, em conjunto, os fatores principais da mudança. Um dos argumentos mais fortes em relação a isso, pode ser visto no exemplo que Durkheim apresentou:

[...] é um fato conhecido que o culto da idade vai se debilitando com a civilização [sociedade com divisão do trabalho social]. Tão desenvolvido outrora [nas sociedades gregárias], reduz-se hoje a algumas práticas de polidez, inspiradas por uma espécie de piedade. Os velhos são muito mais objeto de pena do que de temor. 40

A tradição que preconizava uma forma de transmissão de informações através das gerações dá 


\section{Formação e mudança social}

lugar à troca de informação entre os pares. Assim, a permeabilização das fronteiras traz consigo um conjunto novo de informações que não se transmite dos mais velhos para os mais novos, mas advém dos recém-chegados; colocando as gerações mais antigas à margem do processo.

Muito recentemente, Robert Malcolm Ward Dixon propôs aplicar às sociedades - no caso, especialmente, à língua - o modelo de "equilíbrio pontuado" [punctuated equilibrium] que Niles Eldredge e Stephen Jay Gold (1941-2002) propuseram para a mudança biológica. Nessa proposta, as mudanças ocorreriam por "pontuação" [punctuation] ou por "difusão". ${ }^{41}$ As mudanças por difusão seriam aquelas decorrentes das trocas miúdas entre fronteiras, que causam mudanças, mas o fazem lentamente. Dixon (1997) entende que esse processo de mudança social geraria grandes áreas culturais homogêneas - lembrando sempre que ele refere principalmente às mudanças linguísticas tais como ele encontrou no oeste australiano ou nas terras baixas da Amazônia. As outras mudanças, que ocorreriam por pontuação, decorreriam de grandes e repentinas mudanças ambientais, tais como inundações, invasões, terremotos, descobertas tecnológicas, epidemias, etc. Essas mudanças afetariam as sociedades em seu conjunto de uma só vez, obrigando a todos encontrarem soluções rapidamente para as novas necessidades.

As mudanças por pontuação criariam situações sociais dramáticas, promovendo, até mesmo, o fim 
da sociedade. Essa situação pode ser facilmente compreendida se nos ativermos à presença europeia na região costeira do Brasil, sobretudo no Nordeste, onde esse contato foi mais intenso. Em que pese um primeiro momento de coexistência entre europeus recém-chegados e os habitantes locais, o fluxo imigratório incessante dos europeus promoveu um contato muito intenso entre as sociedades. 0 aparato tecnológico dos europeus dava conta de qualquer iniciativa de resistência dos habitantes locais conta os imigrantes. Os hábitos culturais dessa população local face à população imigrante eminentemente masculina provocou novas gerações de mestiços. ${ }^{42}$ Assim, sobraram poucas alternativas para a população local: fugir, assimilar-se ou ser escravizada. As três opções, infelizmente, ocorreram concomitantemente, provocando, em grande parte dessas sociedades seu completo desaparecimento. ${ }^{43}$

As mudanças por difusão, propostas por Dixon, são difíceis de serem descritas porque envolvem um processo secular de contato entre sociedades. Podemos imaginar, no entanto, que a difusão de sementes como as do milho, ou a difusão de outros cultivos, como a mandioca, tenham decorrido desse tipo de processo. Na região das cabeceiras do rio Xingu, onde diferentes sociedades promovem trocas diversas, pode-se encontrar coisa parecida. No começo do século XX, Franz Uri Boas (1858-1942) já havia proposto que uma ideia pode tornar-se efetiva 


\section{Formação e mudança social}

sempre que as condições étnicas sejam favoráveis à sua adoção e ao seu desenvolvimento. ${ }^{44}$

Podemos ainda buscar exemplos em que o contato pela fronteira entre sociedade com diferença na origem e no tamanho não provocou necessariamente mudanças sociais dramáticas como as que a pontuação pressupõe. É comum entre as sociedades tupi-guarani enterrarem seus mortos na própria casa onde viveram. Paralela a esse costume, há a crença de que as almas desses mortos, quando desorientadas por algum motivo em seu percurso post-mortem, perambulem pelas aldeias, provocando grandes problemas e, inadvertidamente, até mortes dos que eram, então, entes queridos. Quando isso ocorre, e não é possível fazer com que a alma perdida encontre seu rumo, é comum que se abandone a aldeia para se estabelecerem noutro local. A escolha do novo local exige que não tenha sido ocupado anteriormente, caso contrário, o perigo das almas perdidas seria o mesmo. Dessa maneira, ocorre um rodízio constante que não provoca nenhuma "superocupação" da terra, pois o novo local ou terá de ser mata virgem ou de mata cujos resíduos de ocupação já tenham desaparecido completamente. Quando há terra disponível, esse rodízio pode ser realizado, mas com a diminuição do espaço, pela concorrência territorial com outras sociedades, não há como ser realizado. A criação de cemitérios mudou o lugar de enterrar os mortos para longe das aldeias, evitando assim a possibilidade de almas perdidas 
perambularem em local próximo à vida cotidiana das aldeias. Trata-se de uma solução estabelecida por um novo hábito que não provocou grandes mudanças na sociedade, senão o fato de não terem mais esse motivo para abandonarem a aldeia para fundarem nova em local de mata virgem. Apesar do novo hábito, as fronteiras étnicas permaneceram impermeáveis, garantindo a identidade grupal.

A presença continuada de missionários entre os diversos grupos indígenas no Brasil foi responsável por grande parte da mudança social desses grupos. Desde o século XVI, novas crenças a respeito das relações entre homens e mulheres foram divulgadas com apoio de muita retórica e de muito castigo para concorrer com as crenças tradicionais. Em certa ocasião em que estive junto aos guaranis, pude verificar que a proposição da monogamia como única alternativa conjugal desencadeou uma geração de mulheres solteiras que buscaram parceiros fora de seu grupo, trazendo-os para dentro de sua aldeia, por ser uma sociedade matrilocal. Conforme se verá mais adiante, as relações próprias entre genro e sogro não se mantiveram como preconizava a tradição. As novas famílias elementares se reduziram a pais e filhos e se multiplicaram na mesma proporção desses casamentos híbridos. A distribuição comunal da terra perdeu espaço para a sua divisão em pequenas porções familiares, inacessíveis aos demais. A correção para esse desajuste provocado pela inserção da crença monogâmica numa sociedade 


\section{Formação e mudança social}

matrilocal teve de ser feita por meio de intermináveis discussões que resultaram às vezes no acordo entre as partes, às vezes na expulsão dos resistentes, às vezes na proibição da matrilocalidade para as mulheres que buscavam seus parceiros fora do grupo.

Desse ponto de vista, a mudança social promovida pela inserção de novas crenças, de novos hábitos ou de novas tecnologias nas culturas tradicionais não desencadeia por si só a modernização da sociedade receptora. Ainda que esses exemplos apontem para a mudança social decorrente de inserções de crenças no grupo pelo contato intercultural, trata-se especialmente de fenômenos de hibridação. Néstor García Canclini definiu esses fenômenos como "processos socioculturais nos quais estruturas ou práticas discretas, que existem de forma separada, se combinam para gerar novas estruturas, objetos e práticas". 45 A absorção das novidades que pode gerar formas híbridas é uma das formas de refazimento homeostático para a manutenção da sociedade.

Se tomarmos a proposta de Dixon de forma conjugada com a de Durkheim, a exemplo do que já fizemos em relação a Linton, podemos entender a mudança de uma sociedade formada por similitude para uma formada por complementaridade como um dos processos de pontuação que se desencadeiam por motivos vários. Assim, embora essa mudança ocorra no eixo do tempo, ela é apenas uma dentre as muitas que poderiam ocorrer. Sua 
importância decorre apenas do alcance extremado que teve no mundo ocidental. A passagem de sociedade tradicional para moderna parece, então, ter ocorrido somente em algumas sociedades ocidentais, fato que não justificaria sua generalização.

Desse ponto de vista, temos que tratar as sociedades em geral, não como uma sequência evolutiva do simples para o complexo, mas como fatos sociais que se superpuseram uns aos outros em momentos diferentes com intensidade variável. A migração isolada desses fatos sociais gera hibridismos, tal como os propôs Canclini e se mostra como um processo de difusão; a migração massiva de fatos sociais, entretanto, pode causar mudanças profundas, como foi o caso da formação da sociedade moderna.

Em que pese o fato de Durkheim ter proposto esse modelo de mudança para todas as sociedades de forma universal, praticamente, isso ocorreu exclusivamente na sociedade ocidental. Com o propósito apenas de compreender esse processo particular de mudança social, podemos pensar que a relação que se estabeleceu entre a sociedade moderna e a tradicional da qual ela procedeu seria a de um recheio de bolo que cresce mais do que a massa e se torna a massa e a massa o recheio. Tratou-se de uma eclosão interna à própria sociedade. As demais sociedades, ao que parece, se modernizaram por difusão. 


\section{Formação e mudança social}

O motor da mudança entre os tipos de solidariedade social é, como vimos, o crescimento e adensamento populacional e a consequente intensificação na troca de informação que se produz. Podemos entender que a multiplicação de papéis envolve não só a recategorização dos status, como também as suas formas de transmissão e de manutenção.

Ainda que a intensidade da troca de informações promovesse a divisão do trabalho social e, portanto, a especialização dos indivíduos às novas atividades, por conta do aumento da densidade populacional, Durkheim entendeu que esse adensamento só promoveria a divisão do trabalho se fosse acompanhado de um aumento populacional. Sua hipótese principal para o aumento populacional vir acompanhado de densidade populacional recaia especialmente sobre a imigração, ou seja, a chegada massiva de estrangeiros na sociedade tradicional receptora. As cidades, resultados desse processo, "não se formam por uma espécie de crescimento espontâneo, mas por imigração". ${ }^{46}$

Um exemplo que pode corroborar a hipótese de Durkheim é a transformação por que passa a cidade de São Paulo no final do século XIX até as primeiras décadas do século XX. De uma sociedade tradicional eminentemente agrária, com total dependência econômica da atividade cafeeira, em trinta ou quarenta anos, a cidade de São Paulo se desenvolveu de forma crescente para uma sociedade industrial moderna. Caio da Silva Prado Junior (1907-1990) salientou que a partir de 1880, a maior parte das 
fazendas de café contaria quase exclusivamente com trabalhadores livres.

0 progresso da imigração no último quartel do século será rápido. Ela começa a crescer depois de 1871, atingindo em 1886 pouco mais de 30.000 indivíduos. No ano seguinte, quando a abolição do regime servil se mostrava já iminente, salta bruscamente para 55.000; e no próprio ano da abolição [...] sobe para mais do dobro deste número ... (133.000). Daí por diante, e até o fim do século, a imigração se conservará sempre num nível médio anual largamente superior a 100.000 .47

A se considerarem os números apresentados pelo autor, podemos supor algo em torno de um milhão de imigrantes no estado de São Paulo, nesse período. Essa presença massiva de imigrantes, por sua vez, caracteriza o adensamento populacional. Richard McGee Morse (1922-2001) chamou a atenção para o fato de que no final do século XIX era patente o influxo de fazendeiros para a cidade bem como o maior número de mulheres nas profissões liberais. Ainda desse ponto de vista, ele ressaltou o "abandono das ocupações rurais pelas comerciais, industriais, burocráticas e intelectuais". ${ }^{48}$ Para ele, "era a imigração estrangeira a fonte das novas ocupações comerciais e técnicas". 49 João de Scantimburgo (1915-2013) também foi taxativo ao afirmar que "os cafeicultores não se converteram em industriais" 50 corroborando a opinião que já havia sido manifesta por Prado Jr. de que "a maior parte da indústria brasileira encontrou-se logo nas mãos de adventícios de recente data ou de seus 


\section{Formação e mudança social}

sucessores imediatos". ${ }^{1}$ Vale lembrar que o mesmo autor afirmava que São Paulo se tornaria rapidamente o maior produtor industrial do Brasil com $40 \%$ do total. Morse mostrou que em 1886 a população estrangeira na cidade de São Paulo era em torno de $25 \%$ do total, devido tanto à migração da zona rural para a cidade como à própria imigração estrangeira vinda diretamente à cidade. ${ }^{52}$

O aumento populacional da cidade de São Paulo ao longo desses anos, aliado às condições econômicas favoráveis pelo acúmulo de capital proveniente da indústria cafeeira, foi responsável pela transformação de uma sociedade tradicional agrária numa sociedade moderna industrial. Esse fato não corrobora somente a hipótese de Durkheim, mas também aquela de Boas, de que seria preciso haver condições étnicas, que podemos chamar de culturais, favoráveis à implementação de novas tecnologias. No caso em questão, o benfazejo final do trabalho escravo promoveu uma mudança cultural que permitiu a implementação de novas ideias. Prado Jr. comenta que a presença de imigrantes alemães, suíços, portugueses e belgas em fazendas cafeeiras, ainda em meados do século XIX, teve um desfecho lastimável. ${ }^{53}$ Segundo o autor, os proprietários acostumados a lidar com a truculência abusiva própria do regime escravagista mostraram-se totalmente ineptos para lidar com trabalhadores livres em suas propriedades. ${ }^{54}$

A mudança cultural promovida pelo adensamento populacional atingiu diretamente os costumes da 
população urbana. Uma citação de Warren Kempton Dean é bastante ilustrativa a esse respeito.

Nem a elite rural nem o grupo de negociantes nascidos no país conheciam muita coisa das preferências dietéticas, indumentárias ou arquitetônicas dos europeus. Alguns fazendeiros construíram moinhos para fabricar farinha de mandioca e de milho que eles e suas próprias classes inferiores estavam acostumados a comer, mas não apareciam no negócio da moagem da farinha de trigo. Comerciantes italianos, portugueses e sírios importavam o bacalhau salgado, os chapéus de feltro, a pasta, o azeite de oliva, a cerveja, as especiarias e o vinho de que os europeus gostavam e logo principiaram a manufaturá-los, ao lado de outros produtos, cuja importação da Europa teria sido excessivamente dispendiosa, como trabalhos ornamentais de mármore e móveis de madeira. ${ }^{55}$

A modernização que se viu na cidade de São Paulo, decorrente de sua industrialização, não representa necessariamente uma melhoria na qualidade de vida da população. Ainda que novos hábitos fossem implementados, o mesmo autor ${ }^{56}$ chama a atenção, para a algumas fotografias de época que apresentam "uma horda de espectros descarnados e andajosos, apinhados à saída, precedidos de crianças descalças e raquíticas, com os rostos inexpressivos voltados para a câmara ou para o chão". ${ }^{57}$ Essa situação e outras semelhantes desencadeariam diversos movimentos para formar associações de trabalhadores além da formação do Partido Comunista Brasileiro nesse período, fatos que 


\section{Formação e mudança social}

corroboram a hipótese da necessidade da "correção reparadora" tal como proposta por Durkheim.

Ainda desse ponto de vista, será proveitoso retomar o conjunto de associações de trabalhadores de São Paulo, que participaram do congresso fundador da COB - a Confederação Operária Brasileira —, em 1906, conforme o detalhamento de Hermínio Linhares: Sindicato dos Trabalhadores Gráficos, União dos Chapeleiros, Liga dos Trabalhadores em Madeira, Liga dos Pedreiros e Anexos, Sindicado dos Trabalhadores em Veículos, Sindicato dos Metalúrgicos, Sindicato dos Trabalhadores em Fábricas de Tecidos, Sindicato dos Transportadores de Tijolos, Sindicato dos Trabalhadores em Pedra Granito, Liga dos Pintores, Liga das Costureira em Carreação, Sindicato dos Trabalhadores em Olarias, Sindicato dos Oficiais Alfaiates ${ }^{58}$, dentre outros que atuavam em outras cidades do estado de São Paulo. Ainda que durante os períodos colonial e imperial tenham ocorrido inúmeras revoltas de trabalhadores escravizados no Brasil, essas associações fundaram movimentos trabalhistas característicos das sociedades modernas industrializadas. Saliente-se que esse conjunto de associações aponta para um crescente aumento da divisão do trabalho social. A modernização decorrente, num primeiro momento, da imigração para São Paulo e, num segundo momento, da industrialização mostrou-se como um processo sem volta.

A tensão que se formou entre as forças rurais reacionárias e os movimentos industriais caracte- 
rizaram precisamente o conflito entre a consciência coletiva das sociedades tradicionais com a consciência individual das sociedades modernas, ou, nos termos de Gellner, o movimento de transformação do próprio Estado Agrário para um Estado Industrial. ${ }^{59}$ Os Estados seriam fortemente estratificados e estabeleceriam funções características para os seus membros segundo critérios fortuitos ou tradicionalmente definidos. A partir do grupo que comande as instituições do poder, se estabeleceriam todos os modelos de prestígio e a sua necessidade de divulgação e preservação. Os Estados Industriais se definiriam pela consideração geral de que todos os seus membros se caracterizariam apenas como mão de obra, efetivos ou potenciais, tendo de ter o conhecimento mínimo necessário para atuar apenas como força de trabalho de acordo com as necessidades do momento. Assim, o Estado Industrial desconsideraria diferenças culturais e imporia suas necessidades a toda a população.

No que diz respeito à linguagem, haveria de se considerar tão somente a necessidade de veiculação rápida e eficaz de todo tipo de informação à população. Nesse caso, por exemplo, seria de fundamental importância a homogeneização da linguagem bem como a sua ampla divulgação. Os grupos culturalmente diferentes que coexistiram no Estado Agrário teriam de se submeter à homogeneização como fator primordial para a sua sobrevivência como conjunto de indivíduos, ainda 


\section{Formação e mudança social}

que isso implicasse o seu desaparecimento como grupo diferenciado dos demais.

Ainda segundo Gellner, seria nos Estados Industriais que a escola assumiria o seu papel mais transformador. ${ }^{60} \mathrm{Na}$ medida em que teria de tornar todos os cidadãos aptos para exercerem seu papel, a despeito das características tradicionais de seus grupos, a escola seria o único meio, ou pelo menos o mais privilegiado, de inserção do indivíduo no mercado de trabalho. Seria na escola que o cidadão obteria as habilidades e conhecimentos mínimos necessários para que pudesse assumir seu papel de mão de obra na indústria ou no comércio. A rejeição à escola acarretaria a marginalização e a impossibilidade de obter o sustento pelas vias da legalidade mantida pelo Estado. Nesse caso ainda se poderiam acrescentar os meios de comunicação como o meio alternativo transformador do indivíduo, para torná-lo apto a assumir as suas funções no mercado de trabalho.

A distinção entre o Estado Agrário e o Estado Industrial, entretanto, não se mostraria como um limite bem definido, mas permite conceber que ambos estivessem imbricados, entrevendo-se, neste, formas que caracterizassem aquele $\mathrm{e}$ vice-versa. Em relação a essa mudança de estado agrário para estado industrial, Dean reproduziu a opinião de um europeu, a passeio em São Paulo, que a descreveu "de maneira nenhuma comparável à sociedade dos velhos povos". ${ }^{61}$ Segundo Dean, ele 
encontrou um sistema de classes "nada fechadas, sem quaisquer semelhanças com castas".

Para Durkheim, as sociedades tradicionais poderiam eventualmente ocorrer de forma patológica, constituindo o que ele chamou de "divisão do trabalho anômica". Tais sociedades poderiam, por sua vez, constituir-se em dois tipos "mórbidos": um que se basearia na divisão por classes e castas e outro que se basearia no regime de escravidão. 0 Estado Agrário brasileiro, até o final do século XIX, baseava-se em ambos os tipos mórbidos. A sociedade paulista caracterizava-se pela divisão social em classes ou castas. Basicamente como o próprio Gellner descreveu o Estado Agrário, a sociedade paulista compunha-se até o final do século XIX, de fazendeiros ricos, inclusive portadores de títulos de nobreza, militares, religiosos e, um pequeno conjunto de profissionais liberais e de trabalhadores livres. Além disso, também se caracterizava pela divisão social entre homens e mulheres livres, dentre os quais eram todos os descritos acima, e homens e mulheres escravizados, que eram os negros e seus descendentes e os índios. Segundo Durkheim, essas condições sociais não seriam suficientes para a divisão do trabalho social e, portanto, não promoveriam a transformação de uma sociedade tradicional para uma moderna. ${ }^{62}$

[...] a divisão do trabalho só produz a solidariedade se for espontânea e na medida em que for espontânea. Mas, por espontaneidade, 


\section{Formação e mudança social}

deve-se entender a ausência, não apenas de qualquer violência expressa e formal, mas de tudo que pode tolher, mesmo indiretamente, a livre expansão da força social que cada um traz em si. 63

Ainda que possamos tomar a proposta de Durkheim por demais otimista - ele mesmo, logo adiante, salientou que não existiria espontaneidade perfeita e que a hereditariedade comumente atravessaria o caminho da "livre expansão da força social de cada um" 64 - tratava-se de uma proposição bastante coerente com a situação social paulista que sucedeu a sua transformação. A partir daí, é fácil perceber o paralelismo entre sociedade tradicional-sociedade moderna e Estado Agrário/Estado Industrial desenvolvendo-se em São Paulo.

A imigração não tinha como motivo a mudança cultural do mundo agrário para o industrial, mas tão somente substituir a mão de obra no meio rural; no entanto, como previa a hipótese de Durkheim, a ocorrência numerosa da imigração acarretou mudanças, desencadeando a própria industrialização em São Paulo. As mudanças por sua vez não se confinaram na área econômica. Como já vimos, a culinária encerra um ciclo de farinha de milho e de mandioca tradicionais na região e dá a vez para a farinha de trigo, com todas as novas receitas que ela traria consigo. Também nas crenças, podemos encontrar a figura do saci que, de um ente maléfico próprio das narrativas tradicionais do ambiente rural, vem para a cidade com forma fixa determinada por José Bento Renato Monteiro 
Lobato (1882-1948), devidamente moldada em três dimensões por Victor Brecheret (1894-1855). 65 Além disso, outros aspectos poderiam ser salientados. Vamos priorizar a educação escolar como um dos fatos sociais que mais fortemente foram influenciados pela mudança que se observou.

Conforme já vimos, a escola para Gellner seria um dos meios de transmissão de conhecimento que teria um papel preponderante no Estado Industrial. Sua função principal seria a de fornecer à grande massa populacional a ser disponibilizada como mão de obra um conjunto mínimo de habilidades e conhecimentos para que todos estivessem minimamente preparados quando fossem chamados para o mercado de trabalho. Esse conhecimento mínimo seria exatamente a alfabetização, a matemática e as relações formalmente instituídas do poder. Podemos entender melhor isso, retomando as ideias de George Simmel (1858-1918) na passagem do século XIX para o XX.

[...] uma diferença de nível entre a massa e o indivíduo só pode surgir e ser concebida desde que no indivíduo, as mesmas qualidades e modos de comportamento com os quais ele "forma a massa" - e com o qual ele se introduz no espírito comum - sejam separadas das demais, que simultaneamente constituem sua propriedade privada e com os quais ele, como indivíduo, se separa do contexto partilhado com todos os demais. 66 


\section{Formação e mudança social}

A hipótese de Simmel é de que haja um comportamento coletivo mínimo, ou seja, um padrão comportamental mínimo compartilhado por todos os indivíduos formadores da "massa". Esse padrão comportamental mínimo e comum a todos é o que caracterizaria a sociedade, isto é, que orientaria as ações da sociedade como um todo, que formaria os propósitos da sociedade, com plena objetividade. ${ }^{67} \mathrm{~A}$ origem desse padrão foi proposta não só em sentido biológico, mas também por "elementos espirituais que se objetivariam em palavras e conhecimentos, em inclinações afetivas e normas de vontade e juízo e que penetrariam o indivíduo como tradições conscientes e inconscientes". ${ }^{68} 0$ autor entendia que esse conjunto de "elementos espirituais objetivados em palavras e conhecimentos em inclinações afetivas e normas de vontade e juízo" fariam parte do conhecimento interiorizado dos indivíduos que comporiam a sociedade. De certa maneira, esse conjunto de elementos espirituais seria o mesmo que o senso comum de Geertz e os demais conceitos semelhantes propostos por outros autores. A hipótese de Simmel era a de que esse senso comum formasse uma base coletiva que sustentasse a sociedade e que aparecesse de forma extremada quando houvesse a reunião de vários indivíduos no mesmo espaço. A individualidade só se manifestaria, pois, acima desse senso comum, por meio de "palavras e conhecimentos, inclinações afetivas e juízos" que não fossem compartilhadas por todos. 
Podemos entender que, a partir da hipótese de Simmel, a escola se tornou um dos principais formadores desse senso comum que possibilita num Estado Industrial a uniformização dos cidadãos. Assim, quanto mais eficaz no sentido de levar essa formação mínima a todos os cidadãos, tanto melhor terá cumprido sua função de formar a mão de obra adequada ao mercado de trabalho. Portanto, a escola, no Estado Industrial, inverteu o sentido da modernidade ao promover a homogeneização e o controle da informação básica substituindo as funções que eram próprias da tradição. A individuação característica da modernidade ficaria, portanto, além da escolarização, numa situação de formação diferenciada entre os cidadãos.

0 crescimento da escola pública em São Paulo teve um aumento significativo a partir da primeira década do século XX. Ana Maria Catelli Infantosi da Costa apresentou dados indicando que, em 1908, eram 3\% da população que estavam matriculados na escola primária e, em 1923, esse número aumentou para 6,8\%. A concentração dos estudantes ocorria, entretanto, especialmente no ensino primário o que, segundo a autora, indicava que a proposta do ensino público na época estava voltada especialmente para a alfabetização. Segundo ela "A escola primária ao restringir sua contribuição ao nível mínimo, isto é, limitar-se ao ensino das técnicas de ler, escrever e contar, permitiu aos poderes constituídos ampliar 


\section{Formação e mudança social}

significativamente a oferta de serviços educacionais." 69

Considerando-se a proposta de Gellner para o contraste entre um Estado Agrário e um Estado Industrial, saliente-se que, durante os períodos de colônia e de império, o ensino promovido pelas escolas particulares, mormente as de cunho religioso, era voltado principalmente para os filhos da aristocracia paulista e ia muito além do ensino elementar e que o ensino popular era praticamente inexistente. Isso caracterizaria a divisão mórbida em classes e castas e, ainda pior, em livres e cativos. Nos primeiros anos da Primeira República brasileira (1889-1930), houve a proposta de que a escola pública ensinasse o mínimo necessário, o que seria um sinal claro da mudança em questão. Costa apresentou dados que mostraram que, na cidade de São Paulo, em 1920, a população alfabetizada com 15 anos ou mais atingiu o patamar de $71,4 \%$ do total. ${ }^{70}$ Podemos dizer que a industria-lização, como elemento próprio da modernidade em São Paulo, criou também a figura do analfabeto que, até então, não existia ou não precisava existir.

Numa sociedade tradicional inexistem analfabetos. Saber ler e escrever é apenas uma atividade marginal que, eventualmente pode servir para estabelecer algum contato entre os povos. 0 desenvolvimento de novas tecnologias em sociedades tradicionais não se mostra como um fator de mudança por si só. Em trabalho anterior, ainda nos anos 90, pude verificar que, "após quase 500 anos de 
contato com a língua escrita, novamente os Guarani mantêm-se completamente alheios a ela". ${ }^{71}$ As condições culturais, em São Paulo mostravam-se extremamente favoráveis ao ensino das primeiras letras, da matemática e das relações de poder. Neste caso, não só por meio das comemorações cívicas, mas também por meio de disciplinas como as de história e geografia cujo conteúdo voltava-se para uma versão oficializada dos fatos. Podemos pensar que, a despeito de uma ou outra meritosa exceção e de inúmeras tentativas de mudanças, a escola pública permaneceu até hoje com esse mesmo caráter. A dificuldade de implementação do ensino de uma língua estrangeira, por exemplo, é bastante sintomática. 0 conhecimento de uma segunda língua, mesmo que seja o inglês, ainda é um diferenciador individual que traz vantagens significativas para o ingresso no mercado de trabalho. E é, de fato, uma das diferenças que contrapõem o ensino público e o privado no Brasil. 


\section{Senso comum}

A expressão "senso comum", cunhada por Thomas Paine (1737-1809) em 1776, num panfleto que leva esse mesmo nome, aparece tão somente três vezes, além do título, no texto que escreveu. 0 propósito do panfleto era o de convencer o leitor de que a independência da colônia britânica na América era uma necessidade premente para o bem de toda a população. No texto, a expressão aparece pela primeira vez quando o autor pretende caracterizar sua própria argumentação: "Nas páginas seguinte não ofereço nada além de fatos simples, argumentos e senso comum..." 72 .

Por enumerar conceitos - fatos, argumentos e senso - podemos aventar a hipótese de que se trata de uma sequência processual em que o "senso comum" é o ponto de chegada. Assim, ainda nessa mesma hipótese, podemos também imaginar que o autor apresentará fatos, em seguida, argumentos e, então, considerações sobre eles. Desse ponto de vista, essas considerações serão feitas sem o uso da sofisticação própria que se esperaria numa discussão dessa natureza. Por exemplo, o autor apresentou como fato a proteção que a Grã-Bretanha daria à sua colônia na América, o argumento era que a proteção feita não seria contra os inimigos da colônia, mas contra os inimigos da própria Grã-Bretanha. Nesse caso, as considerações envolviam a objetivação de que tais inimigos seriam 
inimigos da Grã-Bretanha e não de sua colônia na América e, portanto, com a independência, os americanos poderiam ter amizade com países que, até então, eram tidos como inimigos.

A segunda vez que a expressão ocorre tem a ver novamente com a forma da argumentação que será feita: "Examinaremos essa ligação e a dependência com base nos princípios da natureza e do senso comum. " 73

O próprio paralelismo - natureza e senso comum - estabelecido pelo autor vai no mesmo sentido do raciocínio que fizemos; de certa maneira, o senso comum opõe-se à natureza e é, ao mesmo tempo, complementar a ela. Uma vez que o "princípio da natureza" poderiam ser os fatos que caracterizariam a ligação e a dependência propriamente ditas da colônia com a Grã-Bretanha, poderíamos mais uma vez aventar a hipótese de que o senso comum seria para o autor a reflexão que se poderia fazer quanto a isso. Portanto, temos novamente a ideia de que a expressão "senso comum" foi utilizada como o processo que permite a objetivação dessas reflexões. 0 autor ainda usou a expressão mais uma vez com essa mesma proposta.

Dirão alguns talvez que, após entrarmos em paz com a Grã-Bretanha, ela nos protegerá. Podemos ser tão insensatos a ponto de pretender dizer que ela manterá para tal fim uma frota em nossos portos? O senso comum nos dirá que o poder que tentou submeter-nos é, dentre todos, o menos indicado para nos proteger. ${ }^{74}$ 


\section{Senso comum}

Trata-se do próprio raciocínio baseado na experiência que a expressão procura focalizar. Nesse exemplo, a expressão "senso comum" opõe-se à outra que carrega o sentido de "insensatos", como na tradução, mas poderia ser também "imprudentes". Esta aponta para uma reflexão malfeita, que não avalia os fatos conforme a experiência, isto é, o conhecimento acumulado por todos. Na medida em que o senso comum de Paine parece considerar o conhecimento acumulado pela experiência, podemos acrescentar à nossa hipótese de que se trata de uma reflexão especialmente indutiva. Assim, a partir de fatos e argumentos disponíveis no conhecimento acumulado, seria possível extrair alguma regra geral acertada. Em relação a esse tipo de raciocínio, Karl Raimund Popper (1902-1994) afirmou que:

O estágio inicial, o ato de conceber ou inventar uma teoria, parece-me não reclamar análise lógica, nem ser dela suscetível. A questão de saber como uma ideia nova ocorre ao homem trate-se de um tema musical, de um conflito dramático ou de uma teoria científica - pode revestir-se de grande interesse para a psicologia empírica, mas não interessa à lógica do conhecimento científico. ${ }^{75}$

As ideias novas, portanto, tal como foram tomadas pelo autor, qualquer natureza que tenham, não decorreriam de um raciocínio dedutivo. Tratava-se de uma aproximação grande da noção de senso comum que aqui procuramos definir, a partir do uso que Paine (2005) fez dela. Esse estágio inicial 
intuitivo em que se concebeu ou se inventou uma teoria, uma regra geral para o mundo não se confundiria, pois, com o próprio conhecimento acumulado, ainda que fosse consequência dele. Popper foi ainda além disso, afirmando que "ideias arriscadas, antecipações injustificadas, pensamento especulativo, seriam os únicos meios de que poderíamos lançar mão para interpretar a natureza: nosso único organon, nosso único instrumento para apreendê-la." $76 \quad 0$ senso comum seria, aparentemente o instrumento a que Popper se referia.

0 procedimento especulativo, entretanto, não é nem um pouco seguro e, por isso mesmo, requer uma atenção especial. Certamente é o senso comum a principal fonte de preconceitos, de violência, de injustiças sociais e, por isso, a sua versão correta, o "bom senso", também precisa ser considerada. De fato, o bom senso seria, pelo menos entre nós, a tentativa de aplicação correta do pensamento especulativo: é o senso comum que dá certo, o que está de acordo com o bem-estar de todos. Seja qual for a expressão, embora tenhamos clara preferência pela de senso comum, elas terminaram historicamente por se contrapor à de pensamento científico. Novamente recorremos a Popper.

A partir de uma ideia nova, formulada conjecturalmente e ainda não justificada de algum modo - antecipação, hipótese, sistema teórico ou algo análogo - podem-se tirar conclusões por meio da dedução lógica. Essas conclusões são, em seguida, comparadas entre si 


\section{Senso comum}

e com outros enunciados pertinentes de modo a descobrir-se que relações lógicas (equivalência, dedutibilidade, compatibilidade ou incompatibilidade) existem no caso. ${ }^{77}$

Vê-se que, nessa proposta, à geração de ideia nova, qualquer que tenha sido a forma de concebê-la, deveria seguir um segundo procedimento que visasse ao reconhecimento da existência de relações lógicas entre essa ideia nova e outras já existentes. Portanto, ela deveria ser coerente com o conhecimento que já foi produzido. Essa comparação, no entanto, que consistiria na prova da teoria, vai além da mera coerência. Popper propôs quatro momentos: 1) a comparação lógica propriamente dita; 2) a verificação da forma lógica da teoria, em que se confirmaria não se tratar de tautologia, isto é, de pensamento circular; 3) a comparação com outras teorias, no sentido de se confirmar se a ideia seria realmente nova e, finalmente, 4) a aplicação empírica das conclusões que se possam extrair dela, com o propósito de confirmar ou infirmar sua capacidade de fazer previsões. ${ }^{78}$ Podemos dizer que no senso comum apenas parcialmente o primeiro desses quatro momentos seria aplicado. 0 que nos leva a entender que, desse ponto de vista, o senso comum é uma precipitação do raciocínio, ou seja, propõe a regra geral antes de ela ter sido efetivamente testada e comprovada. A oposição entre pensamento científico e senso comum tem sido amplamente discutida por filósofos diversos. ${ }^{79}$ Por não se tratar de nossos propósitos, não vamos nos aprofundar aqui nessa questão. Vamos somente 
selecionar alguns autores para destacar suas propostas e, então, utilizá-las.

Antes disso, porém, é conveniente explorarmos o conceito de "cultura", uma vez que ele está intimamente relacionado com o de senso comum. De forma muito minuciosa, Roque de Barros Laraia (2004) fez um levantamento das diferentes con-cepções que diversos antropólogos têm ou tiveram desses termos, ainda que sua conclusão seja desanimadora. ${ }^{80}$

Para os propósitos desta nossa abordagem, vamos assumir conjuntamente duas definições. Roger Martin Keesing (1935-1993) propôs que a corrente antropológica neoevolucionista, que trata a cultura como um sistema adaptativo, em que pesem suas diferenças, concorda que:

Culturas são sistemas (de padrões de comportamento socialmente transmitidos) que servem para adaptar as comunidades humanas aos seus embasamentos biológicos. Esse modo de vida das comunidades inclui tecnologias e modos de organização econômica, padrões de estabelecimento, de agrupamentos social e organização política, crenças e práticas religiosas, e assim por diante. 81

A proposta de que as culturas são "padrões de comportamento socialmente transmitidos" coere precisamente com nossas considerações a propósito das sociedades tradicionais e mesmo das modernas. Os padrões comportamentais socialmente transmitidos implicam a manutenção temporal da sociedade, mas podem ser colocados em risco assim que 


\section{Senso comum}

novos padrões sejam acrescentados pela permeabilidade das fronteiras. Em relação ao senso comum, podemos entender, com alguma boa vontade, que poderia encaixar-se tanto na noção de crenças, quanto na incômoda expressão "assim por diante".

Uma outra corrente, a que trata da cultura como sistemas simbólicos, é descrita por Keesing:

[...] a cultura deve ser considerada não um complexo de comportamentos concretos, mas um conjunto de mecanismos de controle, planos, receitas, regras, intenções (que os técnicos de computadores chamam de programas) para governar o comportamento. ${ }^{82}$

Ainda que grosseiramente, podemos entender que a distinção entre a cultura como sistema adaptativo e a cultura como sistema simbólico se assemelharia àquela entre a competência e o desempenho, e as relações que eles mantêm entre si. ${ }^{83}$ As descrições dos desempenhos, tais como dos padrões de comportamentos socialmente transmitidos, se associariam a um complexo conjunto de instruções cognitivas para sua realização. Tais comportamentos, entretanto, seriam continuamente monitorados, uma vez que não ocorreriam no vazio, mas entre um conjunto de outras pessoas, que também teriam seus padrões comportamentais. Haveria, portanto, um mecanismo de autoavaliação social constante definido por Geertz como um mecanismo de controle - muitas vezes rigoroso, muitas vezes, não. 
Com a bênção de Popper, podemos propor a hipótese de que o senso comum age especialmente nesse procedimento de autoavaliação social, constituindo-se, pois, como uma parte própria do que se chamaria de cultura, nos termos em que a estamos tomando aqui. Se pendermos para o propósito da adaptação, entenderemos que o critério a ser aplicado ao senso comum é o de verificar se a adaptação está ocorrendo. Parece-nos o caso da noção de senso comum de Paine que, pela avaliação feita por seu próprio senso comum, entendeu que a situação de dependência em que ele e seus conterrâneos se encontravam não teria como continuar até um bom termo e, portanto, seria inadaptativa.

Nigel Barley (1983) escreveu uma passagem significativa em seu relato de quando esteve entre os dowayo, na República dos Camarões. Ao ser levado por um fazedor de chuva ao local onde este escondia os segredos de sua mágica, foi-lhe revelado que a peça principal, chamada de "pedra", com que podia fazer chover era uma "bola de gude azul de criança, das que se compram em qualquer lugar". ${ }^{84}$ 0 fazedor de chuva atribuía-lhe imenso poder e assegurava tratar-se de um objeto que pertenceu a seus antepassados e que estava atualmente em seu poder. 0 autor relatou que esteve posteriormente na cidade e comprou uma bola de gude azul de criança idêntica àquela que lhe foi mostrada. Ao levá-la para o fazedor de chuva, teve, com ele, o seguinte diálogo: 


\section{Senso comum}

- É igual a esta? - Entreguei a bolinha de gude

e ele começou a examiná-la contra a luz assombrado.

-É igual. As nuvens de dentro são mais escuras.

- Você poderia fazer chover com essa pedra?

Olhando-me perplexo, respondeu:

- Como você quer que eu saiba? Para ver se funciona, eu teria que testá-la. Não posso dizer até que a tenha testado. 85

Esse diálogo nos leva para além da descrição do desempenho ou da avaliação adaptativa do desempenho. Trata-se de uma questão essencialmente simbólica, isto é, as condições materiais apresentadas - bola de gude azul de criança - eram as mesmas, eram idênticas entre as pedras, mas não havia como saber se a nova pedra tinha o poder desencadeador da chuva que a antiga sabidamente tinha. A argumentação de Barley conduz para a forma cognitiva de se perceber o mundo e não somente a sua materialidade.

Agnes Heller chamou o senso comum de "saber cotidiano" e o definiu como "a soma de nossos conhecimentos sobre a realidade que utilizamos de um modo efetivo na vida cotidiana da maneira mais heterogênea (como guia para as ações, como temas de conversas, etc.)". ${ }^{86}$ Para ela, seria uma categoria tanto objetiva como normativa, sujeita às variações de época, de estratos sociais, dentre outras. Seria normativa, segundo ela, porque os indivíduos deveriam apropriar-se desses conhecimentos para poderem integrar-se a seu estrato. A proposição de Heller, portanto, era a de que o saber cotidiano não 
tivesse de ser o mesmo para todos no conjunto de uma sociedade, isto é, ele acompanharia a organização social interna da sociedade. A heterogeneidade cultural de Velho acompanha muito de perto essa proposição de Heller, corrobo-rando a hipótese de que as sociedades complexas seriam conflituosas.

Retomando a hipótese de Simmel, podemos entender que as mesmas qualidades e comportamentos mínimos que formariam a massa fariam parte desse mesmo saber cotidiano, mas que não se sujeitariam às diferenças de gênero, estrato social, idade, dentre muitos outros aspectos que se impõem em uma sociedade qualquer. Vimos no capítulo anterior que esse conjunto de crenças é transmitido entre as gerações no caso das sociedades tradicionais e, nas sociedades modernas, é transmitido tanto entre as gerações como entre os pares. Neste último caso, podemos entender como transmissão horizontal tanto a escola como as diferentes formas de fazê-lo pelos meios de comunicação disponíveis, como livros, filmes, histórias em quadrinhos, animações, canções, etc.

Esse conjunto de conhecimentos e habilidades partilhado pelos membros de uma sociedade, tal como propõe Heller não é imóvel. Ao contrário, sujeita-se a quaisquer vicissitudes sociais, sofrendo um constante processo de adaptação. Podemos imaginar, portanto, que não há razão para o tomarmos como um sistema coeso e coerente de 


\section{Senso comum}

crenças, apesar de ele se mostrar suficientemente estável para sua aplicação durante algum tempo.

Trazer à tona esse senso comum não é um procedimento corriqueiro nem isento de dificuldades. Por se tratar de crenças e habilidades comuns a todos, o senso comum passa despercebido como fato cultural e, para usar uma expressão de Gellner, é tratado como se fizesse parte da "natureza das coisas". Assim, a distribuição dos indivíduos entre os status de homem e mulher parece fazer parte da natureza dos indivíduos, bem como os diferentes papéis que se atribui a essa divisão; o mesmo ocorre com os status de criança, adolescente e adulto, ou entre os de trabalhador e patrão, ou entre trabalhador livre e trabalhador escravo, dentre muitas outras atribuições de status. Por se tratar de uma percepção condicionada socialmente desde a infância, seu portador não se dá conta de sua existência, que lhe parece natural como a fala ou a respiração. Seu reconhecimento só se torna possível quando ocorre o contraste entre crenças diferentes ou quando a própria realidade não se comporta como era prevista pelo senso comum.

Geertz tratou dessa questão, apresentando uma situação em que a distribuição dos status de homem e de mulher não era suficiente para dar conta dos fatos. Retomando os trabalhos de Edgerton (1964) e de Hill (1935), Geertz propôs que os grupos distribuíssem status diferentes para os membros de suas sociedades conforme sua percepção da configuração dos órgãos genitais. 
Por se tratar de um fenômeno físico característico que, segundo a concepção de Blackless e outros (2000), alcança $1,7 \%$ dos nascidos vivos, a intersexualidade, ainda que relativamente rara, manifesta-se de forma regular nas sociedades. $\mathrm{Na}$ medida em que quebra o paradigma do dimorfismo sexual, ela teria de ser incorporada no conjunto de saberes cotidianos, isto é, teria de fazer parte do senso comum na sociedade.

Entre os Polkot, um grupo étnico do leste africano, atribui-se à intersexualidade o status especial de um desvio da formação fisiológica, impossibilitando seu portador de receber seja o status de homem, seja o de mulher e, por consequência, de exercer quaisquer de seus papéis. Trata-se, pois, de um indivíduo que deve receber atenção, sobretudo no que diz respeito à sua manutenção. Quanto ao senso comum desse grupo, o dimorfismo sexual faz parte como fato objetivo, ainda que possa haver casos que fujam à regra, isto é, as exceções são tratadas como casos especiais.

Entre o Navajo, grupo étnico que vive no sudoeste da América do Norte, a atribuição de status sexuais a seus membros prevê uma terceira opção relativa à intersexualidade. Nesse grupo, esses indivíduos recebem os status de homem e de mulher simultaneamente e são tratados com deferência especial na medida em que são capazes de conhecer e desempenhar ambos os papéis. Segundo Geertz, ostentar essa característica seria motivo de 


\section{Senso comum}

prestígio, uma vez que tais indivíduos intersexuais trariam "boa sorte e riquezas".

Situação diferente ocorreria na sociedade estadunidense. Ainda segundo Geertz, no período em que Edgerton fez seu levantamento, constatou-se que a intersexualidade era tratada como uma anormalidade que deveria ser corrigida o quanto antes possível. 0 dimorfismo sexual concebido por essa sociedade se superporia à própria realidade que deveria transformar-se a fim de adequar-se a suas próprias concepções, ou seja, não haveria como encaixar um intersexual no conjunto de crenças disponíveis, não sendo, portanto, possível atribuir-lhe algum status.

A diferença entre essas três concepções de mundo relativas a essas três sociedades diferentes diz respeito, segundo Geertz, a diferenças no senso comum entre cada uma dessas sociedades. Trata-se, pois, de um conjunto de crenças transmitidas entre as gerações e pelas gerações.

Voltamos, portanto, à hipótese de Durkheim quando propunha uma maior homogeneidade para as sociedades tradicionais e uma maior heterogeneidade para as sociedades modernas. 0 conjunto de informações que são transmitidas entre as várias gerações, numa sociedade formada predominantemente por solidariedade mecânica, ou pelos pares, numa sociedade formada predominantemente por solidariedade orgânica, constitui um corpo de conhecimento partilhado pelos membros de uma 
mesma sociedade. Durkheim chama esse conhecimento partilhado de "consciência comum" ou de "consciência coletiva". Para ele a consciência comum estaria diretamente associada à força dos vínculos sociais entre os indivíduos, sendo maior quando a consciência coletiva fosse maior do que a individual. ${ }^{87}$

Charles Sanders Peirce (1839-1914) propôs que seriam quatro os métodos de as crenças se fixarem entre os indivíduos. 0 primeiro método - que chamou de método de tenacidade - seria o do hábito, o da resposta repetida constantemente e que nos faria apegar a tudo que pudesse conduzir àquela crença e nos faria desviar "com desgosto e irritação de tudo quanto possa perturbá-la". O segundo método - que chamou de método da autoridade decorreria do poder institucional. Seria, segundo ele, um dos meios principais para sustentar doutrinas teológicas e políticas: "o massacre de todos os que não pensem de certa maneira tem-se mostrado meio muito eficaz de igualar as opiniões em um país". ${ }^{88} 0$ terceiro método - que chamou de método a priori - estaria relacionado às inclinações do indivíduo ou da sociedade; seria o de optar entre alternativas igualmente viáveis, ainda que sem qualquer justificativa. Finalmente, o quarto método - o da ciência - o autor propôs como o único que deveria ser levado em conta, pois seria o único a introduzir realidade.

Na medida em que o método científico de fixação de crenças se estabeleceria apenas em círculos sociais 


\section{Senso comum}

muito restritos, somente os três primeiros métodos atuariam diretamente na formação do consciente coletivo proposto por Durkheim. Podemos pensar no método da tenacidade e no da autoridade como os principais no contexto de uma sociedade formada predominantemente por solidariedade mecânica. ${ }^{89}$

Uma das figuras híbridas tradicionais que se desenvolveram no Brasil foi o saci, particularmente na zona rural da região sudeste brasileira. De tradição, sobretudo portuguesa, do Pesadelo e do Fradinho da Mão Furada, por sua vez originados dos Koboldes germânicos, 90 o saci ganhou cor preta, perdeu uma perna e vive nos bambuzais. Trata-se de uma figura maléfica, um anjo demoníaco, ainda que modernamente não se lhe atribua esse caráter. No entanto, permanece para muitos como figura maléfica e vingativa. Sua imagem concorreu à de mascote da Copa do Mundo de Futebol no ano de 2014, mas não foi vitoriosa; venceu a imagem de um tatu chamado Fuleco, que não fez muito sucesso. Como não poderia deixar de ser, atribuiu-se a derrota vergonhosa da seleção brasileira ao caráter vingativo da figura do saci, exatamente pelo número de sete gols, o que seria claramente a marca deixada pelo autor da vingança.

Por ser a crença na figura do saci o que garante a coerência entre eventos que aparentemente não teriam relação entre si - a seleção da figura da mascote, a falta de jogadores importantes na seleção brasileira, a habilidade do time adversário, a quantidade de gols sofridos, dentre outras - 
somente a demonstração de falsidade lógica seria capaz de quebrar esse conjunto de fatos que coerem entre si especialmente pela intermediação do sobrenatural. Como se verá mais adiante, a figura do saci é um símbolo icônico, criado discursivamente, que não tem referência (Bedeutung). Demonstrar que algo inexistente é de fato inexistente é logicamente impossível, fenômeno conhecido como regressão infinita ${ }^{91}$, pois sempre haverá a possibilidade de se criar um fato ainda mais primitivo que daria origem a outro, e novamente a outro, e assim sucessivamente. 0 que corrobora essa crença no sobrenatural é sua flexibilidade para a organização dos fatos sob um mesmo ponto de vista.

Durkheim propôs que a transmissão de crenças e práticas sociais entre as gerações atuaria no sentido de intensificar o consciente coletivo do grupo. Essa transmissão poderia dar-se tanto pelo método da tenacidade como pelo da autoridade peircianos. A imposição de crenças exigiria a institucionalização das mesmas, isto é, a criação de um estado, de uma igreja ou de, pelo menos, de um embrião dessas instituições. Também exigiria a seleção de um representante, dentre os da sociedade, que assumisse essa posição de liderança. Durkheim propôs que, num caso de despotismo não patológico, essa dominação decorreria da própria sociedade que optaria pela organização centralizada naquele que melhor encarnasse as crenças e os sentimentos comuns da sociedade. Dessa maneira, o líder despótico não patológico seria uma espécie de 


\section{Senso comum}

cidadão prototípico detentor de todo o conhecimento que cada um possuiria apenas parcialmente. ${ }^{92}$

Já discuti alhures 93 a hipótese de Maurice Halbwachs (1877-1945) de que esse conhecimento pode decorrer da experiência pessoal do falante, caso em que podemos pensar em memória individual, ou pode decorrer de uma composição grupal, em que podemos pensar em memória coletiva. A memória individual seria caracterizada pelo testemunho do indivíduo dos fatos que serão recuperados. ${ }^{94}$ Entretanto, dada a característica fragmentária dessa memória individual humana, ${ }^{95}$ as recordações não só precisariam de um constante apoio de técnicas de memorização, como também de ser consolidadas a partir de seu cotejo constante com os pares que testemunharam os mesmos fatos. Halbwachs chamou de memória coletiva esse conjunto de informações compartilhadas por todos indi-víduos de uma mesma sociedade. Assim, a memória coletiva se comporia pela coincidência de lembran-ças comuns decorrentes das mesmas experiências e pela troca de informações individualmente memorizadas.

Comparando a hipótese de Durkheim de consciência coletiva e a de Halbwachs de memória coletiva, podemos entender que abordam fenômenos cuja semelhança é imensa. No entanto, Halbwachs propôs que a memória individual se compusesse também de dados cujo portador não teria sido testemunha direta. Assim, mesmo a memória individual seria resultado do intercurso de diversos 
indivíduos. Ainda que essa hipótese seja coerente com a proposta de Durkheim quanto às sociedades tradicionais, ela oferece um detalhamento desse processo que nos permite abordar a transmissão de conhecimento seja pelo processo da tradição seja pelo da comunicação entre pares de forma mais eficiente. 0 ideal é partirmos das formas tradicionais.

O apoio de técnicas de memorização da memória coletiva dá-se pelas formas mais diversas. Podemos pensar num fenômeno corriqueiro, que estabelece status para todos os membros do grupo e que, ao mesmo tempo, é universal, na medida em que decorre diretamente da fisiologia dos indivíduos no processo de procriação; trata-se especificamente da formação da família. No heredograma abaixo, em que bolinhas são mulheres e quadradinhos são homens, a associação direta dessas figuras por traço horizontal aponta associação conjugal, a associação indireta dessas figuras por um traço vertical subordinado a um horizontal aponta associação fraternal, a associação vertical associada a uma associação conjugal aponta filiação. A cor preta nas figuras marca parentesco consanguíneo, a cor branca marca parentesco por afinidade. ${ }^{96} 0$ heredograma mostra uma formação familiar conhecida como de tipo iroquês ${ }^{97}$ ou dravidiano, ${ }^{98}$ que são bastante comuns entre grupos da família linguística tupi-guarani no Brasil. ${ }^{99}$ Ainda que estejamos acostumados a pensar numa família elementar como aquela formada somente por pais e 


\section{Senso comum}

filhos - marcada no heredograma pelo quadrado de linhas pontilhadas, ao centro - no sistema iroquês a família elementar, ou grupo de siblings pela definição de Alfred Reginald Radcliffe-Brown (1881-1955), ${ }^{100}$ é a que tem todas as figuras pretas. $\mathrm{Na}$ discussão sobre esse tipo de análise de parentesco, esse autor chamou a atenção para o fato de que "há normalmente algum elemento de atitude ou de comportamento considerado como apropriado a todos os parentes designados por este termo e não aos outros". ${ }^{101}$ Nesse sistema, o que chamaríamos de irmão(s) do pai e irmã(s) da mãe são igualmente tratados como pai e mãe, respectivamente. Assim, todos os que têm o(s) mesmo(s) pai(s) e a(s) mesma(s) mãe(s) são tratados como irmãos ou irmãs. Nenhuma forma de relacionamento conjugal é permitida entre eles. As figuras que têm cor preta com uma marca branca não são tratadas da mesma maneira, pois o sexo dos parentes a que se irmanam é diferente. Assim, irmã(s) do pai ou irmão(s) da mãe não são considerados nem pai nem mãe, portanto não fazem parte da família elementar. Também não fazem parte da família elementar todos os descendentes da(s) irmã(s) do pai ou do(s) irmão(s) da mãe. Pode haver relacionamento conjugal entre qualquer um desses marcados em rosa, com qualquer um dos membros da família elementar, marcados na cor preta. 


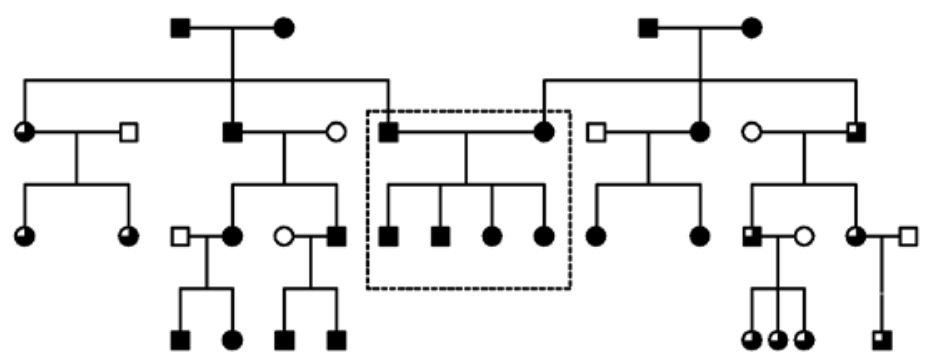

A associação conjugal nesse tipo de formação familiar é estabelecida desde o nascimento e não precisa ocorrer necessariamente entre indivíduos de mesmo nível familiar. Note-se que os homens da família elementar têm apenas duas opções para casamento pelo lado paterno e quatro opções pelo lado materno. As mulheres não têm nenhuma opção pelo lado paterno e têm somente três opções pelo lado materno. Neste último caso, como dois dos homens do lado materno já estão casados, resta às mulheres apenas uma opção. Se a associação conjugal for um fato obrigatório, como costuma ser, os homens do lado paterno terão de associar-se conjugalmente com as mulheres solteiras, ou viúvas, da família elementar, estabelecendo uma poligamia praticamente obrigatória nessa sociedade.

Por se tratar de um sistema complexo que não permite falhas, a manutenção das relações sociais, mesmo que os membros da família elementar vivam distantes uns dos outros, dá-se pela nomenclatura de parentesco. É comum que, nessas circunstâncias, os indivíduos refiram-se uns aos outros pelo nome de parentesco e não por qualquer nome individual 


\section{Senso comum}

que tenham. Eventualmente alguns apelidos ocorrem entre indivíduos de mesmo nível familiar. Entre os guaranis, por exemplo, é possível verificar a ocorrência de mais de três dezenas de termos de parentesco. 102 Ainda que a terminologia de parentesco sirva de técnica mnemônica no grupo, o reconhecimento dos graus de parentesco pode dar-se pela vida cotidiana quando todos os membros da família maior convivem numa mesma aldeia. Em ambos os casos, trata-se do próprio consciente coletivo de Durkheim, ou a memória coletiva de Halbwachs, que forma um sistema complexo de crenças e conhecimentos compartilhados entre todos os membros do grupo.

Esse sistema de crenças que se transmite entre as gerações, bem como as relações que cada indivíduo tem de ter com os demais parentes, garante, dentre outros fatos, a coesão do grupo e a possibilidade de se estabelecer relações de troca com outros grupos. As figuras marcadas em branco, no heredograma acima, que representam o parentesco não consanguíneo, caracterizam o ponto de entrada no sistema e, portanto, no próprio grupo.

O sistema de parentesco é uma das formas que as sociedades tradicionais, e mesmo as modernas, têm que podem ser usadas para manter a coesão grupal, pela manutenção dos status e de seus papéis correspondentes. Dean chamou a atenção para o fato de que "as fontes potenciais de mútua hostilidade social" entre fazendeiros e industriais foi amenizada durante a Primeira República em São 
Paulo por causa das alianças matrimoniais que se estabeleceram entre eles. ${ }^{103}$ De maneira geral, pelos dados apresentados pelo autor, a estratégia foi a de estimular o casamento entre filhas de fazendeiros e filhos de imigrantes, baseada no princípio de casamentos exogâmicos e nas trocas matrimoniais. A partir desse tipo de aliança, a tradição aristocrática e a modernidade industrial fundiam-se numa classe relativamente estável que manteria amplo poder político na região.

Numa sociedade do grupo linguístico tupi-guarani, em que o sistema de parentesco pode ser classificado como iroquês ou dravidiano, como o caso que exemplificamos acima, ao obter o status de genro em relação a outro que, por sua vez, obtém o status de sogro - , o indivíduo passa a ter de desempenhar um papel específico, prescrito para esse status, ou pelo menos, é isso que a sociedade espera dele. 0 genro, que passa a morar na casa da família de sua esposa, matrilocalidade, assume o compromisso de prestar serviços ao sogro.

Numa narrativa tenharim coletada em Humaitá, AM, o locutor fez uma pequena digressão para explicar ao ouvinte a relação que se estabelece entre o genro e o sogro.

Eu vou contar a história do mukura. Esses mukura... Não tem mukura? Mukura. É. A filha... Ele tinha uma filha. Ele tinha uma filha. Ele tinha uma filha, aí, ele foi casar com... com... mutuca. Você conhece aquele mutucão? Aquele grandona, né? Mutucão... Ele casou com mutuca: a filha do 


\section{Senso comum}

mukura, né? Aí, ele falou para... para o... mutuca... marido... era marido... era marido da... marido dela. Ele falou assim:

- Vamos tirar mel para o meu pai? Meu pai está querendo mel. - Porque nós... o costume nosso, do Tenharim, por exemplo, quando casa com a filha de algum homem, nós tem que fazer de tudo para o pai dela. Se o pai dela está precisando, está precisando de lenha, nós, não precisa mandar, nós temos que ir. Aí, nós vamos tirar lenha. Outra vez, está querendo comer, aí, nós temos que ir. Quando ele espera que não, nós já estamos chegando com alguma coisa para ele. Esse é que é o costume nosso. ${ }^{104}$

Numa situação cotidiana, em que se produziria essa narrativa, a digressão seria totalmente desnecessária, bastando, pois, a mera apresentação dos eventos para que os mesmos servissem como exemplo do comportamento esperado para o status em questão. Na transcrição de uma narrativa Kamayurá, também da família linguística tupi-guarani, que trata da origem da mandioca, o herói Pakuẽ casa-se e vai morar com sua esposa. Na aldeia da esposa não há comida.

Pakuẽ fez roça, como daqui lá no aeroporto. Fez roça grande. Plantou. O pessoal de Pakuẽ veio, plantou para ele. Depois nasceu muita mandioca, ficou bom para ele comer. Mulher de Pakuẽ, o pai dela achou bom Pakuẽ arranjar beiju e mandioca. ${ }^{105}$

O herói Pakuẽ, entretanto, faz sexo com a cunhada, deixando-a grávida. Por isso é expulso pela sogra. 
Ele pede para que os de sua aldeia arranquem toda a mandioca que ele havia plantado.

Pakuẽ voltou para esconder três ramas para a mulher dele, que já estava "buchada". Ele disse que ia embora, e disse que a rama estava escondida: para quando o filho nascer, o pai da mulher plantar; ela encontrou a rama de mandioca. 0 pai dela plantou. A mandioca nasceu, devagarzinho, fez roça, depois outra e assim foi aumentando. Nasceu muita mandioca. 106

O herói Pakuẽ vai morar na casa do sogro, dá-lhe a mandioca, mesmo a contragosto dos seus pares. Não há essa explicação no texto, há somente os eventos, que servem de modelo.

George Devereux (1908-1985) entendia que a cultura teria um papel ainda mais importante na formação do indivíduo.

0 inconsciente étnico de um indivíduo é aquela parte de seu inconsciente total que tem em comum com a maioria dos membros de sua cultura. Compõe-no tudo o que, de acordo com as exigências de sua cultura, aprende por si mesmo a reprimir e, então, por sua vez, obriga a geração seguinte a reprimir. ${ }^{107}$

Com opinião semelhante, Geertz propôs que o homem não dispusesse pelo nascimento de processos geneticamente programados, como os que podem ser encontrados em animais inferiores. Para ele, o comportamento humano seria tão frouxamente determinado por fontes de informações intrínsecas que as extrínsecas passariam a ser vitais. 


\section{Senso comum}

Assim, como o homem é "o animal mais emocional além de ser o mais racional", é necessário um controle cultural muito cuidadoso dos estímulos de medo, raiva, sugestões, etc. - através de tabus, da homogeneização do comportamento, da rápida "racionalização" de estímulos estranhos em termos de conceitos familiares, etc. - para impedir uma instabilidade afetiva continuada, uma oscilação constante entre os extremos da paixão. Todavia, como o homem não pode atuar eficientemente na ausência de um grau bastante elevado de ativação emocional razoavelmente persistente, são igualmente essenciais mecanismos culturais que assegurem a pronta disponibilidade, e de tipos constantemente variados de experiências sensoriais que possam sustentar tais atividades. 108

Desse ponto de vista, uma das estratégias seria a atribuição de status, como os de homem e mulher, cujo comportamento preconizado socialmente estaria alinhado com essa necessidade. ${ }^{109}$ Verea (2004) lembrou a posição de Tubert (1991) quando esta propôs que seria a identidade de gênero, a classificação nominal como "homem" ou "mulher" que inseriria o indivíduo no discurso de gênero. Essa classificação atribuiria papéis específicos a serem desempenhados e, portanto, geraria também a criação de critérios de avaliação em relação ao desempenho esperado para os status atribuídos. $\mathrm{Na}$ medida em que tais papéis fossem considerados fatos sociais, em termos durkheimianos, seriam anteriores ao indivíduo, pré-existindo a eles conforme reza a tradição. Nesse conjunto de 
comportamentos tradicionais que devem ser desempenhados pelos portadores do status "mulher", estaria o comportamento específico do status "mãe"; um novo status que se atribuiria por eclosão às mulheres que passassem pela sequência, sempre variável interculturalmente: casamento, ato sexual, gravidez, parto e maternidade. ${ }^{110} \mathrm{~A}$ manutenção da sociedade seria um processo decorrente desse conjunto de comportamentos em que cada um contribuiria para a eficácia do processo. Particularmente, ato sexual, gravidez e maternidade seriam necessários, mas não suficientes para a reprodução social. Seria preciso que os três ocorressem subsequentemente para tanto. No que diz respeito à maternidade, Tubert afirmou que

A maternidade é uma construção cultural. É difícil reconhecermos este fenômeno humano, uma vez que há tanto tempo ele é concebido como uma função de caráter instintivo, profundamente arraigada na estrutura biológica feminina, independente das circunstâncias de tempo e espaço que a determinam. 0 fato de ser a procriação um processo natural pode induzir-nos a pensar que ao fenômeno fisiológico de concepção e gestação deve corresponder o desejo de ter um filho e também de determinadas atitudes em relação a ele. Contudo, esta identificação da maternidade social com a reprodução biológica é produto de um sistema de representações. Isto é, de uma ordem simbólica que cria a ilusão da naturalidade, provocando um corte radical na sua própria natureza, instaurado no ser humano pela sua inserção na cultura. ${ }^{111}$ 


\section{Senso comum}

Devereux propôs que as culturas ofereceriam instrumental cognitivo necessário para que os indivíduos, seus portadores, pudessem suportar as adversidades emocionais desencadeadas em diferentes situações. ${ }^{112}$ Para refletir sobre isso, podemos pensar que, apesar da formação social promovida pela tradição ser tomada a partir da supervalorização do núcleo familiar, especial-mente quanto ao papel da mulher na formação desse núcleo, 113 essa relação não precisaria necessariamente ocorrer como tal.

Tem se exagerado socialmente o papel da mulher mãe e, quanto a sua relação com o filho, não parece muito acertado que as mulheres tenham desenvolvido o "instinto" ou a necessidade da maternidade. Prova disso é que, desde sempre, se tem buscado uma maneira de se evitar a gravidez, fato percebido nas diversas civilizações da humanidade. Tudo o que se tem demonstrado é que essa imagem santificada da mulher como mãe não é autêntica. Esse falso ídolo não pode perdurar e continuar subestimando as mulheres como pessoas, sacralizando o que é puramente biológico, o que não a diferencia de nenhuma outra fêmea mamífera, o que não se constitui, na maioria das vezes, um acidente inesperado e uma limitação. ${ }^{114}$

É comum que se veja a rejeição materna aos filhos. $\mathrm{Na}$ medida em que não haja envolvimento emocional entre mãe e recém-nascido, não haveria qualquer relação simpática dela em relação a ele. Não se poderia pensar em rejeição, pois seria ausência de simpatia, ausência de qualquer sen- 
timento. Rejeitar seria uma reação emocional que promoveria uma atitude de separação, de expulsão ou de morte, mas o que se vê é mera apatia, desconhecimento. Em algumas sociedades, motivos muito variados podem gerar antipatia social pelo recém-nascido: gravidez decorrente de relação sexuais impróprias (incesto ou com estrangeiro, por exemplo); malformação congênita, gêmeos, albinismo, garantia de prole 115 e, ainda, a depressão pós-parto. Em nossa sociedade podemos pensar em outras tantas ainda como gravidez indesejada (estupro, sexo casual, adolescente), 116 depressão pós-parto, 117 barriga de aluguel, 118 etc. Numa das cartas de José de Anchieta (1534-1597), ainda no século XVI, descreve-se uma situação em que a ausência de simpatia pelo recém-nascido é evidente.

Estando eu [...] em uma cabana de palma, onde o padre costumava a celebrar missa, [...] ouvi junto dela falar e cavar, e como ali as índias costumavam a fazer louça, pensei que seria isso e não me quis distrair; mas, acabadas as orações, [...] chegou-se ali uma índia, e lhe perguntei o que faziam, e mo disse que enterravam um menino. Pensando eu que haviam morto algum, contou-me ela o que se passara e era que uma havia parido [...] e acabando de nascer dela um menino mui fremoso, o enterrara vivo a velha sua sogra, porque sendo aquela moça prenhe de um que havia por mulher, sendo dele deixada, com outro se casou, de maneira que, segundo a opinião dessa gente, ficava o menino mestiço de duas sementes. ${ }^{119}$ 


\section{Senso comum}

Como a simpatia parece ocorrer apenas depois do parto, ela precisaria ser, de alguma maneira, estimulada para ter o seu início. Pode-se perceber que o estímulo à simpatia pelo recém-nascido é um fato cultural que deve ser promovido pela sociedade. Um poema que se tornou muito conhecido, especialmente pelo verso final - "Ser mãe é padecer num paraíso." - em que Henrique Maximiano Coelho Neto (1864-1934), mais conhecido como Coelho Neto, ainda na Primeira República, apresenta um pequeno roteiro do papel a ser desempenhado pelas mulheres que receberam o status de mãe.

\section{Texto 1: Ser Mãe de Coelho Neto}

Ser mãe é desdobrar fibra por fibra o coração! Ser mãe é ter no alheio lábio que suga, o pedestal do seio, onde a vida, onde o amor, cantando, vibra.

Ser mãe é ser um anjo que se libra sobre um berço dormindo! É ser anseio, é ser temeridade, é ser receio, é ser força que os males equilibra!

Todo o bem que a mãe goza é bem do filho, espelho em que se mira afortunada, Luz que lhe põe nos olhos novo brilho!

Ser mãe é andar chorando num sorriso! Ser mãe é ter um mundo e não ter nada! Ser mãe é padecer num paraíso! ${ }^{120}$

Particularmente na última estrofe, quando o autor se desdobra para colocar conceitos antagônicos 
numa mesma frase - chorando num sorriso, ter um mundo e não ter nada, padecer no paraíso - , são previstas as dificuldades a serem enfrentadas no desempenho desse papel. De certa maneira, é possível verificar a intenção no texto de "dourar a pílula", tendo em vista o reconhecimento de que suportar as adversidades emocionais não são, nem seriam, fáceis de serem contornadas. ${ }^{121}$ Já no século XIX, o Decreto n. 847 - de 11 de outubro de 1890 que promulgou o "Codigo Penal dos Estados Unidos do Brazil" em que se previa o delito atualmente chamado de abandono de incapaz.

Art. 292. Expor, ou abandonar, infante menor de 7 annos, nas ruas, praças, jardins publicos, adros, cemiterios, vestibulos de edificios ou particulares, emfim em qualquer logar, onde por falta de auxilio e cuidados, de que necessite a victima, corra perigo sua vida ou tenha logar a morte:

Pena - de prisão cellular por seis mezes a um anno.

$\S 1^{\mathrm{o}} \mathrm{Si}$ for em logar ermo o abandono, e, por effeito deste, perigar a vida, ou tiver logar a morte do menor:

Pena - de prisão cellular por um a quatro annos.

$\S 2^{\circ}$ Si for autor do crime, o pae ou mãe, ou pessoa encarregada da guarda do menor, soffrerá igual pena com augmento da terça parte. [...] . ${ }^{122}$

Dessa maneira, mais do que adversidades emocionais, o caráter materno preconizado por Coelho Neto joga os extremos máximos à condição da maternidade - da condição angelical sobre o berço para a de prisioneira numa cela de penitenciária - sem quaisquer meios-termos. 


\section{Senso comum}

Posição semelhante vai descrita no poema de Anna Lins dos Guimarães Peixoto (1889-1985), conhecida como Cora Coralina, "Meias impressões de Aninha (mãe)"123 que normatiza com veemência a condição da maternidade: "Cria teus filhos,/ não os entregues à creche./Creche é fria, impessoal./Nunca será um lar/para teu filho./Ele, pequenino, precisa de ti./ Não o desligues da tua força maternal". O pleito é quase o mesmo do Código Civil de 1890, a não ser pelo fato de ter sido produzido muitos anos depois, na segunda metade do séc. XX. A avaliação dos próprios desejos da mulher que recebeu o status de mãe, entretanto, parece ser ainda mais severa: "Que pretendes, mulher?/ Independência, igualdade de condições.../ Empregos fora do lar?/És superior àqueles/que procuras imitar./ Tens o dom divino/de ser mãe". 0 caráter normativo - evidente no poema de Cora Coralina mas apenas subentendido no de Coelho Neto - define os roteiros que se terão de seguir para o desempenho do papel de mãe. A insistência no fato é por si só significativa quanto às possibilidades de desempenho possíveis. Como já se viu, a simpatia pelo recém-nascido é um fenômeno que precisa ser estimulado, para que se fixe como um comportamento natural, que "faz parte da natureza das coisas". Nesse caso, é o método da tenacidade, tal como a proposta de Peirce (1975). No entanto, a versão legal desse estímulo é método da autoridade. Assim como a configuração dos status sexuais segue o princípio do dimorfismo sexual exclusivamente em algumas sociedades, a configuração do status da 
mulher que tenha de desempenhar o papel de mãe, também não oferece outras alternativas. Trata-se, pois, de um fato socialmente definido que se permite tomar no conjunto dos saberes cotidianos e tratá-lo como senso comum.

Retomando a frase de Tubert (1996), "a maternidade é uma construção cultural", lembramos que nas sociedades, como naquelas que já vimos, em que as relações de parentesco seguem um padrão iroquês ou dravidiano, a maternidade se distribui entre as várias mães de um mesmo indivíduo. Essa solução de responsabilidade, prevista no próprio status de mãe, possibilita que o comportamento individual, seja da mãe geradora, seja de qualquer outra mãe, tenha uma flexibilidade muito maior do que o que vai preconizado no poema de Coelho Neto e no de Cora Coralina. 0 vínculo entre a geração biológica e a maternidade num só indivíduo é, novamente retomando Tubert (1996) "um produto de um sistema de representações [...] de uma ordem simbólica que cria a ilusão na naturalidade".

Gellner (1972), quando analisou a passagem histórica da humanidade da vida em comunidade para a vida em sociedade, propôs que a base para essa mudança comportamental fosse o resultado de uma mudança cognitiva. Segundo ele, para o homem que vive em comunidade, poucos contatos com a realidade são "puros"; de maneira geral, esses contatos se confundem com os interesses sociais próprios da comunidade em que se inserem e, assim, têm de ser interpretados simultaneamente por 


\section{Senso comum}

múltiplos pontos de vista previamente estabelecidos. Segundo ele, o homem, nesse caso, estaria imerso num sistema de crenças inter-relacionadas, que apresentaria umas poucas aberturas para o contexto imediato com a realidade. Para ilustrar essa interpretação, Gellner (1972) usa da metáfora de um submarino cultural com múltiplos periscópios. O homem estaria dentro desse submarino cultural, mas teria, vez ou outra, possibilidade de observar a realidade por meio dessas aberturas periscópicas. Dessa maneira, a interpretação dos fatos reais seria sempre mediada por esse conjunto de crenças e se sujeitaria ao reconhecimento coletivo de suas conclusões. Além de reclamar coerência entre as próprias crenças, também seria condição necessária que as crenças fossem comuns a todos do mesmo grupo. 0 reconhecimento e a interpretação da realidade seriam feitos, de um lado, pela coerência entre as crenças, tomadas coletivamente, e, de outro, nos raros momentos em que a realidade se sobressai a esse sistema de crenças e se permite observar diretamente.

Mário Raul de Morais Andrade (1893-1945), ou simplesmente Mário de Andrade, foi um dos que, no início do século XX, já tinha sintetizado essa situação, embora se referisse mais especificamente à produção artística. Para ele, estaríamos sempre confinados, não num submarino, mas por uma superposição de véus que atuariam como filtros de natureza vária na percepção da realidade. Como 
vimos no capítulo anterior, o autor se encontrava num momento de mudança social.

Nossos sentidos são frágeis. A percepção das coisas exteriores é fraca, prejudicada por mil véus, provenientes das nossas taras físicas e morais: doenças, preconceitos, indisposições, antipatias, ignorâncias, hereditariedade, circunstâncias de tempo, de lugar, etc... Só idealmente podemos conceber os objetos como os atos na sua inteireza bela ou feia. A arte que, mesmo tirando os seus temas do mundo objetivo, desenvolve-se em comparações afastadas, exageradas, sem exatidão aparente, ou indica os objetos, como um universal, sem delimitação qualificativa nenhuma, tem o poder de nos conduzir a essa idealização livre, musical. Esta idealização livre, subjetiva, permite criar todo um ambiente de realidades ideais onde sentimentos, seres e coisas, belezas e defeitos se apresentam na sua plenitude heroica, que ultrapassa a defeituosa percepção dos sentidos. ${ }^{124}$

Com a divisão social do trabalho, na passagem para a vida em sociedade, essa multiplicidade de interpretações reduziu-se a interpretações específicas e unitárias para cada fato selecionado da realidade. A partir dessa divisão relativa à percepção da realidade, Gellner (1972) estabeleceu que houvesse duas grandes formas de aproveitamento da realidade: o uso da realidade para confirmar as necessidades culturais próprias da comunidade e o uso da realidade como um sistema de referências fixas que não dependem das necessidades sociais. Ele ainda propôs que a divisão social do trabalho, apesar de sua importância, com sua 


\section{Senso comum}

separação de funções e de propósitos, não seria o ponto de partida da humanidade nem formaria um elemento permanente da condição humana. Desse ponto de vista, o aproveitamento da realidade como um conjunto de referências fixas e independentes se restringiria às sociedades cujos membros teriam passado pelos processos próprios de formação cognitiva que envolvem essa perspectiva, como é o caso da memória histórica definida por Halbwacks. 125 Retomando-se a proposição de Peirce, podemos assumir que essa formação está diretamente associada ao método científico de fixação de crenças; os demais parecem relacionar-se mais intimamente com os processos formação do indivíduo para vida em comunidade.

Heller (1977) propôs, na esteira da divisão entre o que já havia sido proposto como a diferença entre o tradicional e o moderno, que o saber cotidiano fosse transmitido, mesmo nas sociedades que se orientem para o passado, as tradicionais, pelo contato entre as gerações sucessivas, como também por acréscimos que poderiam ser de dupla natureza: os que adviriam de novas experiências e os que adviriam das "objetivações genéricas para si". ${ }^{126}$ Os primeiros já foram longamente considerados no primeiro capítulo deste texto; os segundos necessitam de alguma consideração complementar. Para a autora, as atividades "para si" seriam aquelas que derivariam de fontes secundárias tais como a ciência, a religião, a política, a medicina, dentre outras. Essas fontes demandariam instituições oficializadas para 
garantir o direito de fazê-lo. Encaixam-se nesse conjunto de fontes a Escola, a Igreja, os Meios de Comunicação de Massa, por exemplo. O propósito dessas instituições, segundo a autora, seria o de inserir o conhecimento produzido profissionalmente por especialistas no saber cotidiano e, dessa forma, estabelecer as direções do senso comum.

O conhecimento científico, ainda que fosse o único recomendado no conjunto dos métodos de fixação das crenças de Peirce e das criações de referências fixas de Gellner, do ponto de vista de Heller (1977), dissolve-se no saber cotidiano como quaisquer crenças fixadas pelos métodos da tenacidade e o da autoridade. 0 exemplo dado pela autora é o da recomendação do suco de limão "porque contém vitamina C". 127 Essa crença, ainda que em sua origem tivesse fundamentação científica, atingiria o saber cotidiano apenas pela tenacidade por meio de sua divulgação em meios de comunicação de massa e pela própria escola. Uma vez que se saiba que vitamina $C$ faz bem à saúde e que limonada contém vitamina $C$, pelo senso comum se recomendaria que todos tomassem limonada. A informação, correta ou não, chegaria ao saber cotidiano já devidamente selecionada por várias instituições, cujos objetivos poderiam ser os mais diversos: a melhoria da saúde da população ou o aumento da venda de suco de limão industrializado, por exemplo. Uma vez inserido no saber cotidiano, esse conhecimento adquirido por meio de fontes secundárias receberia o mesmo tratamento dos demais e passaria, 


\section{Senso comum}

portanto, a ser transmitido por gerações sucessivas. De certa maneira, esse processo retoma o sistema de crenças inter-relacionadas no qual o homem imerge.

As proposições de Peirce (1975) e de Gellner (1972) têm em comum assumirem que a referência ao real é o motor da mudança cognitiva humana. Para Peirce, os métodos da tenacidade, da autoridade e do a priori prescindiriam da realidade como o sistema de crenças de Gellner. A ausência de realidade seria, então, compensada pelo próprio discurso que atuaria pela manutenção de comportamentos tradicionais sedimentados nas formas culturais próprias de cada comunidade. Essa imersão num sistema de crenças inter-relacionadas pode ser muito mais extensa do que isso. Fiorin salientou que "A identidade nacional é um discurso. "128 Por se tratar de uma crença perfeitamente integrada no saber cotidiano, ela é tomada pelos seus portadores como fosse parte de seu próprio corpo, nas mesmas condições dos status sociais atribuídos. A respeito desse status que, à semelhança do sexual discutido por Tubert (1996), também é simbólico, podemos entender que

[...] as nações não estão inscritas na natureza das coisas, não constituem uma versão política da doutrina dos seres naturais. Nem tampouco os Estados nacionais representam o destino último dos grupos culturais e étnicos. 0 que existe realmente são culturas, muitas vezes agrupadas subtilmente, fazendo sombra umas às outras, sobrepondo-se e entrelaçando-se. ${ }^{129}$ 
Para Gellner, o nacionalismo adviria da formação desses estados pela consolidação de uma unidade cultural, tal como no conjunto mínimo compartilhado por todos proposto por Simmel (2003). No final dos anos 20, do século XX, Mário de Andrade disse que "a nação brasileira é anterior à nossa raça". ${ }^{130}$ Sua preocupação era a respeito da criação de uma arte especialmente brasileira que, segundo ele "não se faz com escolhas discricionárias e diletante de elementos: uma arte nacional já está feita na inconsciência do povo. 0 artista só tem que dar pros elementos já existentes uma transposição erudita que faça da música popular, música artística." ${ }^{131}$ Mário de Andrade já argumentava no mesmo sentido que ora vimos manifesto de que a nacionalidade é uma construção social feita a partir do discurso sobre a realidade. Disse ele em 1928:

0 período atual do Brasil, especialmente nas artes, é o de nacionalização. Estamos procurando conformar a produção humana do país com a realidade nacional. E é nessa ordem de ideias que justifica-se o conceito de Primitivismo aplicado às orientações de agora. É um engano pensar que o primitivismo é estético. Ele é social [...] Pois toda arte socialmente primitiva que nem a nossa, é arte social, tribal, religiosa. É arte de circunstâncias. É interessada. Toda arte exclusivamente artística e desinteressada não tem cabimento numa fase primitiva, fase de construção. É intrinsecamente individualista. E os efeitos do individualismo artístico no geral são destrutivos. ${ }^{132}$ 


\section{Senso comum}

A proposição de Mário de Andrade era a de que um discurso oficial, erudito, confirmaria o elemento nacional; seria preciso oficializar a arte já existente no inconsciente popular para, então, torná-la efetivamente nacional, brasileira. Trata-se, pois, da inserção de crenças no saber cotidiano definindo indivíduos como pertencentes a esta ou àquela sociedade, a esta ou àquela nação.

Ainda baseados nessa hipótese de que status sociais como sexo, maternidade, nacionalidade, dentre outros, seriam fenômenos discursivos é razoável que os tratemos como tais, tomando-os como enunciados performativos. John Langshaw Austin (1911-1960), no final dos anos 50, propôs que enunciados pudessem ser considerados como constatativos ou como performativos. Os enunciados constatativos seriam descritivos e teriam relação direta com a presença ou não de referência: se as referências forem válidas, o enunciado será verdadeiro, se não forem, será falso. 0 sentido do termo "referência" tomado por Austin (1990) é o que foi proposto por Friedrich Ludwig Gottlob Frege (1848-1925), que o denomina Bedeutung. ${ }^{133}$ Émile Benveniste (1902-1976), define referência como "uma noção constante e 'objetiva', apta a permanecer virtual ou a atualizar-se num objeto singular, e que permanece sempre idêntica na representação que desperta." ${ }^{134}$ No caso de um enunciado em que as palavras não tenham refe-rência, Austin, à semelhança de Frege, propôs que se esteja fazendo pilhéria ou escrevendo poemas. ${ }^{135}$ Para ele 
seria sempre necessário distinguir entre enunciados "sérios" e enunciados "fictícios", ou seja, aqueles cujas palavras têm referência seriam sérios, e aqueles cujas palavras não têm referência seriam "fictícios". Especialmente nesse conjunto de enunciados sérios da linguagem haveria, segundo Austin, a possibilidade de se distinguir entre os enunciados constatativos e enunciados performativos.

Como já vimos, as enunciações constatativas seriam meras descrições referenciais que poderiam ser classificadas em verdadeiras ou falsas. As enunciações performativas teriam de ser avaliadas por critérios que extrapolariam seu valor referencial. $\mathrm{Na}$ medida em que teriam de ser sempre sérias, seria o contexto social que definiria sua eficácia. 0 exemplo de Austin é "Batizo este barco 'Queen Elizabeth' ". Além de todas as referências terem de estar presentes em todas as palavras, essa enunciação teria valor se, e somente se, o enunciador estivesse revestido do poder social de dar nome a um barco. Não seria possível a qualquer outro enunciador, à revelia da determinação social, assumir esse papel. Dessa maneira, é condição necessária para o barco receber o nome Queen Elizabeth que seu "batizador" esteja revestido do status social adequado. Caso esse enunciador não esteja revestido desse status, seu enunciado não será sério. Nos enunciados performativos, a condição de referência das palavras seria necessária, mas não suficiente para a seriedade da enunciação. 0 enunciador teria de cumprir determinadas restrições sociais. Lembramos que numa 


\section{Senso comum}

passagem anterior, tratamos de situação semelhante quando tomamos o status de curandeiro ou de cacique, dizendo que esse status só seria reconhecido pelos demais se houver a capacidade de exercer a liderança do grupo e de curar os doentes. A ausência dessa capacidade denuncia a falsidade do status e, portanto, do discurso.

Dificilmente a distinção entre enunciados sérios e enunciados fictícios, entre ações performativas sérias e fictícias pode ser levada a cabo de uma forma exata quando se olha o mundo de dentro do submarino cultural de Gellner. Mesmo no caso dos status atribuídos, em que o discurso da sexualidade parte de referências fixas como a observação dos órgãos genitais e, com base nas diferenças que encontra, atribui status sexual, a realidade, quando é observada diretamente, se sobressai mostrando que a relação entre órgãos genitais e status sexual não é inequívoca. Desse ponto de vista, a atribuição desse status pelo senso comum é tão somente um enunciado performativo em que, embora não haja uma declaração formal do tipo "eu te declaro homem" ou "eu te declaro mulher", ela se documenta formalmente nos mais diferentes enunciados: nomes próprios, certidões, vestimenta, registros... Richard Rorty (1931-2007) questiona essa diferença entre enunciados sérios e fictícios chamando a atenção para o fato de que a atribuição de referências num discurso é apenas o resultado de propósitos interpretativos. 
[...] a noção de que há algo sobre o que um determinado texto realmente é, algo que a aplicação rigorosa de um método irá revelar, é tão errada quanto a ideia aristotélica de que há algo que uma substância é realmente, intrinsecamente, em contraposição ao que ela é apenas aparentemente, acidentalmente ou relacionalmente. A ideia de que um comentador descobriu o que um texto realmente faz - por exemplo, que ele realmente desmistifica um construto ideológico, ou realmente desconstrói as oposições hierárquicas da metafísica ocidental, e não apenas pode ser utilizado para estes propósitos - é, para nós, pragmatistas — só mais ocultismo. ${ }^{136}$

Ao questionar a essência das coisas, incluindo-se aí os textos, Rorty converte a interpretação dos fatos na extração de informações realizada a partir de um propósito social pré-definido. Se houver interesse social na atribuição desta ou daquela nacionalidade, deste ou daquele sexo, então a atribuição será automática. Se não houver interesse social, não haverá atribuição. Mesmo os performativos formais, que atribuem status definitivos, como sexo ou nacionalidade, estão sujeitos ao reconhecimento social. Nomes próprios, consulados, cartórios, hospitais, médicos, dentre outros, são instituições que estão sujeitas ao reconhecimento formal para garantir o direito de atribuírem status. Benveniste ressaltou que "um enunciado performativo não tem realidade a não ser quando autentificado como ato. Fora das circunstâncias que o tornam performativo, esse enunciado não é mais nada". ${ }^{137}$ Trata-se, pois, de situação incômoda, mas semelhante àquela que 


\section{Senso comum}

vimos anteriormente de que sempre haverá a possibilidade de se criar um fato ainda mais primitivo que daria origem a outro, e novamente a outro, e assim sucessivamente.

0 reconhecimento formal do ato, como propôs Benveniste, sempre exigirá uma instância superior que também o reconheça. É comum, entretanto, que essa recorrência de operações etiológicas seja finalizada também discursivamente. ${ }^{138}$ Essa finalização etiológica pode ser definida na forma de um discurso institucionalizado e escrito. A origem legal das coisas do estado é a Constituição, que se autodefine logo no primeiro artigo: "A República Federativa do Brasil, formada pela união indissolúvel dos Estados e Municípios e do Distrito Federal, constitui-se em Estado Democrático de Direito [...]" O reconhecimento do estado, definido discursivamente, tanto pelas sociedades que ele engloba quanto pelas sociedades de seu entorno, envolve desde o estabelecimento de um território cuja ocupação é exclusiva das sociedades que o reconheceram como uma instância superior que as agrega, até o direito de uso da violência quando essa ocupação exclusiva não for respeitada. 0 status da nacionalidade brasileira por sua vez vai definido na mesma Constituição, Art. 12º; nela, definem-se brasileiros natos como

a) os nascidos na República Federativa do Brasil, ainda que de pais estrangeiros, desde que estes não estejam a serviço de seu país; 
b) os nascidos no estrangeiro, de pai brasileiro ou mãe brasileira, desde que qualquer deles esteja a serviço da República Federativa do Brasil;

c) os nascidos no estrangeiro de pai brasileiro ou de mãe brasileira, desde que sejam registrados em repartição brasileira competente ou venham a residir na República Federativa do Brasil e optem, em qualquer tempo, depois de atingida a maioridade, pela nacionalidade brasileira. ${ }^{139}$

0 texto estabelece o conjunto de condições necessárias para que se possa atribuir o status de brasileiro nato a um indivíduo. Uma vez que tais condições estejam satisfeitas, o indivíduo deverá desempenhar o papel referente a esse status social, quais sejam, além daqueles que se mantiveram pela tradição, também os direitos e deveres constituídos pelos códigos legais institucionalizados de forma igualmente discursiva e escrita. A finalização dessas operações pode também realizar-se pela forma narrativa tradicional. Uma narrativa asteca que descreve o início do mundo faz isso.

\section{Texto 2: A terra foi criada desta maneira}

[...] a terra foi criada desta maneira: dois deuses, Quetazcóatl e Texcatlipoca, baixaram a deusa da terra do céu. Ela tinha as articulações totalmente cheias de olhos e bocas, com as quais mordia como uma besta selvagem. Antes de baixarem-na, já havia água, que ninguém sabe quem a criou, sobre a qual essa deusa caminhava. Vendo isso, os deuses disseram um ao outro: "É necessário fazer a terra" e, dizendo isso, converteram-se os dois em grandes serpentes que agarram a deusa, um pela mão direita e pelo pé esquerdo, e outro pela mão esquerda e pelo pé direito, e 


\section{Senso comum}

puxaram-na tanto que a dividiram pela metade. Da metade de trás dos ombros fizeram a terra e a outra metade levaram ao céu. Por isso, enraiveceram-se os outros deuses. Para recompensar a deusa da terra pelo dano que os dois deuses lhe fizeram, todos os deuses desceram do céu para consolá-la e ordenaram que dela saíssem todos os frutos necessários para a vida dos homens. Por isso fizeram de seus cabelos árvores, flores e ervas; de sua pele, ervas bem pequenas e pequenas flores; dos olhos, poços, fontes e pequenas cavernas; da boca, rios e grandes cavernas; dos buracos do nariz, vales de montanhas; e dos ombros, montanhas. E essa deusa chorava algumas vezes durante a noite, querendo comer corações humanos e não se calava até que lhe dessem não aceitando fruta se não estivesse umedecida com sangue humano. ${ }^{140}$

Nessa narrativa, o espaço terrestre asteca caracteriza-se pelas ações de deuses. Não existe a criação dos deuses nem da água e, ao que parece, também não dos humanos. Não há antecedente para eles, mas há para o mundo onde vivem os astecas. Trata-se, pois, do ponto inicial da história, uma referência fixa para as interpretações que se venham a fazer a respeito disso. Os astecas eram os homens cujos corações alimentavam a deusa da terra, que comiam as frutas originadas de seus cabelos, bebiam as águas originadas dos seus olhos e andavam pelos vales originados de suas narinas. Ainda que também não houvesse uma declaração formal - "eu te declaro asteca" - , a narrativa, por si só, assume o caráter de um discurso performativo se participar do conjunto mínimo de conhecimentos 
que forme uma base coletiva para a formação da sociedade, retomando novamente Simmel (2006). Aqueles que se reconhecessem como descendentes desses primeiros homens assumiriam, pois, o status de asteca e, consequentemente, se sujeitariam a desempenhar o papel que esse status encerrava. Quem não se reconhecesse como tal, não seria asteca e, portanto, não teria de estar entre eles.

Vale notar que, numa sociedade tradicional, a concisão está longe de ser um ideal. A definição dos papéis vai descrita de forma particular, para cada parte especialmente.

\section{Texto 3: Os homens sempre serão tristes se não fizermos alguma coisa}

Os deuses disseram entre si: "Os homens sempre serão tristes, se não fizermos alguma coisa para alegrá-los e para que eles tenham prazer de viver na terra e para que nos celebrem, cantem e dancem. O deus do Vento (Quetzalcóatl) ouviu isso e pensou em seu coração onde poderia encontrar alguma bebida para alegrar os homens e dar-lhes de presente. Pensando, veio à mente uma deusa virgem, chamada Mayahuel que cuidava de uma deusa, sua avó, chaqmada Tzitzímitl. Imediatamente foi até elas, que estavam dormindo, e acordou a virgem e disse: "venho para levá-la ao mundo". Ela ficou imediatamente de acordo e, então, desceram do céu, ele levando a virgem em seus ombros. Logo que chegaram à terra, tornaram-se em uma árvore que tinha dois galhos, um dos quais 


\section{Senso comum}

chamava-se "suco de quetzal", que era o do deus do vento e o outro, "árvore de flores", que era o da virgem. Quando a avó, que dormia, acordou e não encontrou sua neta, chamou rapidamente as outras deusas, também chamadas Tzitzímitl, e desceram todas à terra procurando o deus do vento. Neste momento, os dois galhos da árvore se quebraram e o da virgem foi reconhecido logo pela deusa velha, que o tomou e o quebrou dando a um pedaço a cada uma das outras deusas, que elas comeram. Mas não quebraram o galho do deus do vento, e o deixaram lá; logo que as deusas subiram ao céu, o deus do vento tomou sua forma original, recolheu os ossos da virgem que as deusas tinham comido e os enterrou. Desses ossos saiu uma planta que chamam de metl [agave], com o qual os índios fazem o vinho que bebem e com o qual se embriagam. ${ }^{141}$

Esse sistema de crenças, no qual imergem todos os membros de uma comunidade e que atua no sentido de orientar a todos quanto a seus comportamentos nas diferentes situações da vida comunitária, configura-se como o senso comum, explorado por Geertz (1997). 0 autor, ao tratar do senso comum como um sistema, propõe-no como um conjunto de conhecimentos culturais próprios. Desse ponto, o senso comum é interpretado como o conjunto de conhecimentos transmitidos entre gerações por meio das mais diferentes manifestações orais, bem como por várias outras formas de linguagem, de maneira inconsciente, mas selecionada historicamente pelas sociedades. Nesse caso, estariam não só todas as narrativas como também os mais diferentes 
gêneros utilizados pela Tradição Oral para isso (ditos, piadas, frases feitas...).

A despeito do fato de que já tratamos da proposta de Jan Vansina (1929-2017) em trabalhos anteriores, ela ainda merece considerações. Para Vansina (1982), a Tradição Oral faz uso da linguagem a partir de dois tipos diferentes e complementares entre si: o improviso na sua forma prosódica e o improviso na sua forma lexical. Por tratar de dois aspectos distintos, mas simultâneos, prosódia e léxico assumem nessa proposta um caráter fundamental e interferem na produção linguística desde a fonologia até o discurso. 0 improviso prosódico relaciona-se diretamente com as variações de entoação, velocidade, ritmo, intensidade e qualidade vocal da fala, enquanto que o improviso lexical relaciona-se com a livre escolha de palavras e as consequentes variações fonológicas, morfológicas e sintáticas que dela decorrem. São, portanto, duas habilidades linguísticas distintas que entram em jogo nesse processo. Vansina estabelece uma matriz em que considera os valores prosódicos fixos ou livres nas linhas e os valores lexicais fixos ou livres nas colunas, o que forma dois limites extremos: prosódia fixa e léxico fixo, num extremo, e prosódia livre e léxico livre, no outro extremo. Aos produtos deste, chama de "narrativas" e, aos daquele, "poemas". Embora seja possível encontrar exemplos de poemas entre alguns grupos indígenas no Brasil, como entre os carajás ${ }^{142}$, as canções são um exemplo mais fácil de perceber. Duas ou mais 


\section{Senso comum}

pessoas podem produzir a mesma canção simultaneamente, porque as palavras e a prosódia são invariáveis. Quanto ao outro extremo, as narrativas, que têm forma prosódica livre e forma lexical também livre, há inúmeros exemplos disso que habitualmente realizamos em nossas vidas.

A inserção de novas tecnologias nas sociedades, sobretudo no que diz respeito às formas de documentação da fala, promoveram mudanças nas relações que se estabeleceram entre as práticas de improviso propostas por Vansina. A escrita documenta essencialmente a cadeia lexical, com pouquíssimas possibilidades de documentação prosódica, o que a torna uma forma intermediária, com forma lexical fixa e forma prosódica livre. Ao contrário disso, alguns tipos de música, como o rap e o repente, valem-se de uma forma prosódica fixa e uma forma lexical livre. O cinema, os vídeos na internet, os gravadores de voz, por sua vez, estenderam muitíssimo a quantidade de material com forma lexical e prosódica fixas. A possibilidade de improvisação na forma lexical e na forma prosódica simultaneamente acabou restrita à fala coloquial.

$\mathrm{Na}$ medida em que as narrativas são o suporte linguístico para o sistema de crenças de uma comunidade, entendemos que, a se tomar a proposição de Halbwachs (1990) como verdadeira, as narrativas pessoais serão igualmente o suporte de experiências pessoais e do senso comum, abordadas indistintamente como experiência 
pessoal. Dessa maneira, um sistema de referências, como o de Gellner que permitiria uma narração de fatos reais, substitui-se por um sistema de crenças em que a realidade é atingida apenas pontualmente, sem distinguir-se, no entanto, dos fatos próprios da memória coletiva. 


\section{Individuação}

Da mesma maneira que já havia a preocupação com a formação das sociedades desde os gregos, a formação dos indivíduos também tem ocupado um lugar predominante nas discussões filosóficas até hoje. No diálogo Da Alma, de Platão, Fedón nos conta que Sócrates, em seus últimos momentos, argumentou que a morte tinha de ser considerada de forma positiva pelos filósofos, porque separaria a alma do corpo.

[...] o desligar da alma, segundo afirmamos, é a aspiração principal, constante e própria sobretudo dos que filosofam no sentido próprio da palavra; e a preocupação dos filósofos baseia-se exatamente nisso mesmo, no desligamento e separação da alma e do corpo [...]. Assim, [...] os que filosofam no sentido próprio da palavra se exercitam para morrer e são os homens a quem deve ser menos temeroso estar mortos. ${ }^{143}$

Sócrates afirmava não temer a morte, porque seria o momento de deixar a alma livre das necessidades materiais e poder ocupar-se, então, somente da busca da verdade e do conhecimento. Esse dualismo entre corpo e alma como fenômenos independentes toma a alma como fato isolado que poderia permanecer existindo mesmo desprovida de alguma materialidade que a sustentasse. A alma, nesse caso, seria tomada como algo que pudesse pairar entre as coisas, ser armazenada, ser roubada, migrar entre 
corpos, ocupar corpos de recém-nascidos... Fedón conta no mesmo livro de Platão que Sócrates propunha coisa semelhante.

As almas dos mortos têm existência no Hades ou não? Existe uma tradição antiga, que já mencionamos, que diz que, ao chegar deste mundo no outro, as almas permanecem ali e novamente voltam para cá, nascendo dos mortos. [...] e a prova suficiente de que isso é verdade seria demonstrar de uma maneira evidente que os vivos não têm outra origem senão dos mortos. ${ }^{144}$

A ideia de reencarnação que aparece nesse trecho depende exclusivamente da possibilidade de que as almas possam ser armazenadas e, então, quando for o caso, migrarem para novos corpos. A argumentação que Sócrates daria para justificar isso baseava-se na ideia de que seriam os contrários que se gerariam mutuamente, assim, uma coisa menor geraria uma coisa maior, uma mais fraca geraria uma mais forte, o menor geraria o maior e vice-versa... Da mesma maneira que dormir e acordar gerariam um ao outro, se dos vivos seriam gerados os mortos, os mortos gerariam os vivos. ${ }^{145}$

Assim, podemos convir que também os vivos procedem dos mortos da mesma maneira que os mortos dos vivos, e, sendo assim, parece que há indício suficiente de que é necessário que as almas dos mortos existam em alguma parte, de onde voltem à vida. ${ }^{146}$

Essa hipótese de que as almas pudessem existir separadas de seus corpos permaneceria constante 


\section{Individuação}

em várias discussões no correr dos séculos - e permanece ainda hoje - sobretudo nas discussões que tinham - e têm - caráter religioso. Não há dúvida de que se trata de uma expectativa humana das mais fortes e das que têm ocupado a imaginação de todos em praticamente todas as culturas.

A concepção de alma entre os guaranis também pressupõe que sejam fenômenos independentes e isolados. Os guaranis entendem que as pessoas se formariam com duas almas. ${ }^{147}$ Uma delas, que Cadogan chamou de "telúrica", 148 estaria diretamente relacionada com as condições materiais dos indivíduos, tratando-se, pois, de uma alma que predisporia o indivíduo a todas as necessidades, desejos e comportamentos incontrolados e próprios dos seres vivos. Por se tratar de uma alma terrestre, poderia ser compartilhada por outros seres vivos de natureza diversa. A outra alma, espiritual, estaria relacionada diretamente com as faculdades divinas do indivíduo guarani. Ela seria inserida nas pessoas pelos deuses, com a mediação do pajé.

Para os guaranis haveria quatro deuses: Ñamandu - o principal e criador dos demais - Jakairá, Karaí e Tupã, todos eles relacionados, respectivamente, a quatro princípios que formariam os indivíduos: sabedoria, fumaça, fogo e água. Esses deuses formariam a alma espiritual quando o indivíduo ganhasse seu próprio nome. Os quatro princípios estariam sempre juntos, mas seria de um dos deuses que o pajé reconheceria o nome. A origem divina do 
nome, portanto, estaria diretamente relacionada com o temperamento do indivíduo: os que fossem nomeados por Ñamandu teriam maior apreço pelo conhecimento; os que o fossem por Jakairá teriam mais habilidade nas práticas de cura; os que o fossem por Karaí seriam mais arrebatados; e os que o fossem por Tupã estariam mais capacitados a exercer a conciliação.

A alma espiritual guarani seria uma alma composta. Já a alma telúrica, apesar de una, teria as características próprias dos animais com que seria compartilhada, o que poderia levar à ferocidade da onça ou à imprudência do tapir, por exemplo. Como se dá também em outras religiões, para se atingir a perfeição, os guaranis teriam de conseguir suplantar totalmente as imperfeições impostas pela sua porção telúrica e, assim, ascender à Terra Sem Males ainda em vida.

Ao indivíduo guarani, portanto, não bastaria reconhecer-se como pessoa, mas saber interpretar a si mesmo pela origem divina de sua alma espiritual trazida pelo seu nome e pelo compartilhamento animal de sua alma telúrica. Conhecer-se, nesse caso, implicaria conhecer o animal cuja alma seria compartilhada e esmerar-se na habilidade principal definida pela origem divina de sua alma espiritual. 0 desapego à essa habilidade própria provocaria a saliência de sua alma telúrica com todas as imperfeições que ela manifestaria. Caberia ao pajé fazer a recuperação dessa porção espiritual do enfermo para que, então, o processo de cura 


\section{Individuação}

pudesse ter algum efeito. Após a morte, a alma telúrica permaneceria na terra e a espiritual ascenderia à Terra Sem Males, se não se perder pelo caminho. Neste caso, ambas poderiam existir separada e isoladamente dos corpos em que estivessem contidas, perambulando pelos arredores da sepultura e até os limites da aldeia. Como já vimos anteriormente, seria preciso reconduzi-la para o caminho correto, num caso, ou destruí-la definitivamente, no outro.

No entanto, será a partir das ideias propostas por Aristóteles sobre isso que construiremos nossa discussão. A posição de Aristóteles não segue o dualismo que foi proposto por Sócrates, no Fedón de Platão. Aristóteles não foi o primeiro a abordar o tema. No seu livro "Da alma", ele fez uma longa revisão das propostas anteriores à dele. Para ele, a separação metafísica do indivíduo entre corpo e alma, como fenômenos isolados e separados entre si, não poderia ser levada adiante. Ele entendia que se tratava de abordagens diferentes de um mesmo fenômeno:

Assim, não é necessário perguntar se a alma e o corpo são uma só coisa, da mesma maneira que não é necessário perguntar se a cera e a impressão que faz com ela são uma coisa só, isto é, de maneira geral, perguntar se a matéria de cada coisa é igual à coisa de que ela é matéria. ${ }^{149}$

Segundo essa concepção, a alma seria a forma e/ou a utilidade que se deu à matéria inerte, que deixou de ser inerte por conta disso. Trata-se, pois, de uma 
atribuição que se fez a algo. Em outra passagem, ainda do mesmo texto, Aristóteles deu outros exemplos semelhantes.

Suponhamos que um instrumento ou uma ferramenta, um machado, por exemplo, fosse um corpo natural; a substância do machado será o que faz desse instrumento um machado e ela seria sua alma; suponha que essa alma se separe dele; o instrumento já não será mais um machado a não ser num sentido equivocado [...] Se os olhos fossem um ser vivo, sua alma seria sua visão porque essa é a substância sob a acepção de forma; e se falha a visão, não existe mais nenhum olho, a não ser num sentido equivocado como, por exemplo um olho de pedra ou um olho pintado. ${ }^{150}$

Nesse caso, ele deixou claro que não bastaria ter a forma de um machado, de um olho, mas que seria condição necessária que fossem utilizados como tais. Um olho cego seria, então, um olho sem alma, assim como um machado velho e enferrujado que apenas servisse de suporte. Não se tratava, pois, de coisas separadas entre si, mas de uma abordagem que considerava a atuação humana na atribuição da alma. Quanto ao homem, ele deu o mesmo tratamento, entendendo que a célebre metáfora da alma como o piloto de uma nave não se permitiria evidenciar de nenhuma maneira. ${ }^{151}$

Aristóteles considerou que a alma se caracterizaria pela capacidade de nutrição, sensação, pensamento e movimento do próprio corpo. Ele entendia que, com exceção do pensamento, todas essas partes da 


\section{Individuação}

alma fariam parte do corpo e seriam dependentes dele. 0 pensamento, por sua vez, seria a única parte que admitiria a existência separada do corpo e teria imortalidade. ${ }^{152}$ Além de ser necessário considerar que Aristóteles abordava esse tema partindo somente da especulação teórica - ele estava desprovido de todo tipo de resultados experimentais -, ele tinha de lidar com um vocabulário próprio de sua época. A imortalidade do pensamento, tomada por ele como parte da alma, foi, de fato, uma das hipóteses mais acertadas, sendo que esta nossa discussão sobre as ideias dele corrobora essa hipótese de maneira fortíssima. Aristóteles não descreveu ou não quis descrever a migração do pensamento mediada pela linguagem de um indivíduo para outros ou mesmo para a escrita, quando, então, ganharia ares de imortalidade. Mas, permitiu essa interpretação. Podemos entender que o discurso fazia parte da alma e que, ainda, se sobressairia dela.

Para ele, além do discurso, a alma também se comporia de sensação, movimento e nutrição. Se deixarmos estas duas últimas partes, podemos nos concentrar nas sensações, que foram alvo de longos e detalhados comentários feitos pelo próprio autor. Ao trazer as sensações para a natureza da alma, Aristóteles inaugurou a tradição filosófica que associaria essa capacidade especificamente à formação da alma.

De maneira geral e em relação a todas as sensações, temos de entender que o sentido é o 
que recebe a forma dos objetos sensíveis, sem receber a matéria, da mesma maneira que a cera recebe a impressão do selo de um anel sem o ferro e o ouro, e recebe a impressão do selo de ouro ou bronze, mas não enquanto ouro ou bronze; dessa maneira, em todo caso, o sentido é afetado pelo que tem cor, sabor, som, mas não quanto a cada um desses objetos ser uma coisa em particular, e sim quem enquanto é de tal qualidade e em virtude de sua forma. ${ }^{153}$

Posteriormente, a terminologia vai se dispersar entre diferentes termos relativos a conceitos ora iguais, ora semelhantes. Essa noção aristotélica de alma vai aparecer como "espírito", "mente", "razão", "eu", "ego", "consciência" dentre outras. Os termos utilizados ultimamente são "mente" ou "self", conforme a proposta teórica que se siga. George Berkeley (1685-1753), descreveu o self como

[...] além de toda essa interminável variedade de ideias ou objetos do conhecimento, existe também algo que os conhece ou percebe e que executa diversas operações relativamente a eles, como querer, imaginar ou recordar. Esse ser ativo, perceptivo, é o que chamo de mente, espírito, alma ou eu. Por meio dessas palavras não denoto nenhuma de minhas ideias, mas algo inteiramente diferente delas, no qual elas existem, ou, o que é a mesma coisa, por meio do qual elas são percebidas, pois a existência de uma ideia consiste em ser percebida. ${ }^{154}$

Se mantivermos esse salto de milhares de anos no tempo, como também fizemos quando abordamos as propostas de formação da sociedade, vamos 


\section{Individuação}

encontrar, no século XVIII, a proposta de David Hume (1711-1776).

[...] todas as questões refinadas e sutis acerca da identidade pessoal nunca poderão ser resolvidas devendo ser vistas como dificuldades antes gramaticais que filosóficas. A identidade depende das relações entre as ideias; e essas relações produzem a identidade por meio da transição fácil que ocasionam. Mas, como as relações e a facilidade da transição podem diminuir gradativa e insensivelmente, não possuímos um critério exato que nos permita resolver qualquer controvérsia sobre o momento em que adquirem ou perdem o direito ao nome de identidade. Todas as controvérsias acerca da identidade dos objetos conectados são verbais, exceto enquanto a relação entre as partes gera alguma ficção ou algum princípio imaginário de união. ${ }^{155}$

Ele trouxe o problema da existência ou inexistência do self para dentro da linguagem e atribuiu ao self a mesma propriedade que atribuiu à identidade das coisas.

Passemos agora à explicação da natureza da identidade pessoal [...] É evidente que aqui devemos dar continuidade ao mesmo método de raciocínio que nos permitiu explicar com tanto sucesso a identidade de plantas, animais casas e todas as produções compostas e mutáveis da arte e da natureza. A identidade que atribuímos à mente humana é apenas fictícia, e de um tipo semelhante à que atribuímos a vegetais e corpos animais. ${ }^{156}$

A identificação que Hume fez da mente humana com as coisas, sejam elas naturais ou não, decorre 
especialmente do argumento que ele usou relativo à continuidade das percepções e das relações que se estabeleceriam entre elas: semelhança, contiguidade e causalidade. Para ele, as relações de semelhança estariam diretamente ligadas à memória: "a memória não apenas revela a identidade, mas também contribui para a sua produção, ao produzir a relação de semelhança entre as percepções". ${ }^{157}$ A relação de causalidade estaria baseada no princípio de que a mente humana seria "um sistema de diferentes percepções ou diferentes existências, encadeadas pela relação de causa e efeito, e que produzem, destroem, influenciam e modificam-se umas às outras". ${ }^{158}$ Desse ponto de vista, Hume propôs um dinamismo que não seria compatível com qualquer formação fixa de essência mental, de self, ou outra coisa, mas com uma concatenação multidirecional de causas e consequências alinhadas entre si. Ainda que de forma muito incipiente, a proposição de Hume seria a de que se tratava de uma formação de rede em que o núcleo poderia estar em cada momento, em qualquer parte e, mesmo simultaneamente, em mais de uma parte.

[...] a melhor comparação que eu poderia fazer da alma é com uma república ou comunidade, cujos diversos membros estão unidos por laços recíprocos de governo e subordinação, gerando outras pessoas, que propagam a mesma república pela transformação incessante de suas partes. E assim como a mesma república pode 


\section{Individuação}

mudar não só seus membros, mas também suas leis e constituições, assim também a mesma pessoa pode variar seu caráter e disposição, bem como suas impressões e ideias, sem perder sua identidade. 159

Hume atribuiu toda a responsabilidade da manutenção da identidade à memória, porque só ela que nos faria conhecer a continuidade e a extensão dessa sucessão de percepções e, por consequência, da cadeia de causas e efeitos que constituiria nosso self ou pessoa. Hume, retomou esse aspecto da memória e refez sua afirmação: "a memória não tanto produz, mas revela a identidade pessoal, ao nos mostrar a relação de causa e efeito existente em nossas diferentes percepções". ${ }^{160}$ Assim a memória não seria uma contribuição à formação da identidade, mas uma "revelação" da identidade. Essa afirmação, de certa forma, nos permite imaginar que a identidade decorrente dessa cadeia multidirecional de causalidades é um fato que pode ser analisado isoladamente. Ele ainda disse o seguinte, ao discutir a identidade das coisas:

[...] a controvérsia em torno da identidade não é mera disputa de palavras. Quando atribuímos identidade, em um sentido impróprio, a objetos variáveis e intermitentes, nosso erro não se limita à maneira pela qual nos exprimimos; ao contrário, comumente se faz acompanhar de uma ficção, seja de uma coisa invariável e ininterrupta, seja de algo misterioso e inexplicável, ou ao menos de uma propensão para tais ficções. Para provar essa hipótese [...] basta-nos mostrar, partindo da experiência e da 
observação diárias que os únicos objetos variáveis e descontínuos que supomos continuar os mesmos são os que consistem em uma sucessão de partes conectadas por semelhança, contiguidade ou causalidade. ${ }^{161}$

Hume, nessa passagem, antecipou em mais de cem anos os princípios da gestalt de Max Wertheimer (1880-1943). Do ponto de vista de Hume, bem como no da gestalt, ${ }^{162}$ a identidade seria uma atribuição feita pelo ser humano e, para usar mais uma vez a expressão de Gellner, não faria parte da natureza das coisas. Assim, se tomarmos essa hipótese, teremos que a identidade seria também um fato discursivo, simbólico. Deve, portanto, ser interpretada sob a ótica das teorias dos símbolos e do discurso. $\mathrm{O}$ argumento de Hume antecedeu em muito a criação do cinematógrafo que produz ficção exatamente pelo processo que ele descreveu. A noção de movimento e de identidade, não só das personagens, como do próprio cenário, decorre especialmente da sucessão rápida de quadros semelhantes, sem mudanças abruptas. Trata-se, pois, de uma atribuição de identidade que escapa ao controle da vontade ou da consciência. De fato, não temos nenhum poder sobre isso porque nossos sentidos não são capazes de fazer a segmentação das imagens subsequentes em tempo hábil para que as tomemos como imagens individuais e intermitentes. Para tornar isso possível, teríamos de fazer com que cada uma das imagens fosse apresentada em tempo inferior a 18 imagens por segundo. Nesse caso, 


\section{Individuação}

poderíamos discriminá-las uma a uma e, então, perder a noção de identidade que lhes atribuímos involuntariamente.

Assim, por adiantar os argumentos da gestalt, que viriam somente na virada do século XIX para o XX, Hume teve de valer-se de argumentação metafórica e pouco consistente.

A mente é uma espécie de teatro onde diversas percepções fazem sucessivamente sua aparição; passam, repassam, esvaem-se, e se misturam em uma infinita variedade de posições e situações. Nela não existe, propriamente falando, nem simplicidade, em um momento, nem identidade ao longo de momentos diferentes, embora possamos ter uma propensão natural a imaginar essa simplicidade e identidade. ${ }^{163}$

Ao tentar tratar da sucessão de fatos que ocorreriam em nossa mente, que o autor chamou de diversas percepções, no original "several perceptions", foi necessário valer-se da metáfora do teatro que seria repetida por Goffman (2005) nos anos 60 do século $\mathrm{XX}$. A hipótese de que imagens oriundas dos mais diferentes sentidos apareçam em nossa mente, por sua vez, antecede também em mais de um século a proposta de Peirce, quanto à noção de interpretante. Entretanto, o próprio Hume se incomodou com sua metáfora e reconsiderou:

Mas a comparação com o teatro não nos deve enganar. A mente é constituída unicamente pelas percepções sucessivas; e não temos a menor noção de lugar em que essas cenas são 
representadas ou do material de que esse lugar é composto. ${ }^{164}$

A sucessão de cenas na mente, como propôs Hume, dá prioridade para a visão, fato que foi longamente discutido por David Le Breton em "Antropologia dos sentidos". 165 Quanto à capacidade, ou propensão involuntária de atribuir identidade a essas percepções sucessivas e supor que teríamos uma existência invariável e ininterrupta durante todo o decorrer de nossas vidas, Hume argumentou:

Como apenas a memória nos faz conhecer a continuidade e a extensão dessa sucessão de percepções, devemos considerá-la, sobretudo por essa razão, como a fonte da identidade pessoal. Se não tivéssemos memória, jamais teríamos nenhuma noção de causalidade e, tampouco, por conseguinte, da cadeia de causas e efeitos que constitui nosso eu ou pessoa. ${ }^{166}$

Ao trazer a responsabilidade da atribuição da identidade da sucessão de percepções para a memória, Hume acrescentou um aspecto temporal e comparativo para ela. A identidade de uma percepção qualquer decorreria, portanto, de sua comparação com percepções antigas ou recentes, devidamente memorizadas. De certa maneira, apesar de ter afirmado não ter noção do lugar em que ocorreriam essas percepções, ele parece ter previsto que, de fato, houvesse um lugar para isso, ou mais especificamente, um suporte físico para isso. Ao postular que a memória faria esse papel, 


\section{Individuação}

ressentiu-se do fato de que a memória não fosse, por si só suficiente para tanto.

Mas, uma vez tendo adquirido da memória essa noção de causalidade, podemos estender a mesma cadeia de causa e, consequentemente, a identidade de nossas pessoas, para além de nossa memória, e assim podemos fazê-la abarcar tempos, circunstâncias e ações de que nos esquecemos inteiramente, mas que, em geral, supomos que tenham existido. ${ }^{167}$

Vale lembrar que Rorty (2007) chamou a atenção para o fato de que são os vocabulários de época que definem os pontos de vista. Hume - assim como Aristóteles e, como também veremos, Peirce - não dispunha de um vocabulário que fosse compatível com os conceitos que tentava desenvolver. Assim, ainda que a proposta de Hume tenha sido feita no sentido de argumentar pela inexistência do self, o autor acaba por justificar que, por ser uma construção que se estabeleceu entre a percepção e a memória, o self pode ser tomado como uma unidade formada a um só tempo tanto subjetivamente, pela memória, como objetivamente, pelas percepções.

No início do século XX, o psicólogo social George Herbert Mead (1863-1931) seguiu a proposta de Berkeley (2010), Hume (2009) e Hamilton (1861) ${ }^{168}$. A hipótese de self para Mead (1962) repetia a de Hamilton quanto à possibilidade de se tomar o self tanto como sujeito e como objeto. 
Podemos distinguir bem claramente o self e o corpo. 0 corpo pode estar lá e pode operar de maneira bem inteligente sem ter o envolvimento do self na experiência. 0 self tem a característica de ser um objeto para si mesmo, e essa característica o distingue dos outros objetos e do corpo. 169

A distinção entre corpo e self não era a mesma que se propunha no dualismo platônico entre corpo e alma. Para Mead seria a possibilidade de se tratar o self como objeto que daria a sensação de que o self poderia ser separado do corpo e adquirir existência independente.

[...] eu poderia dizer, o self não é um organismo fisiológico. 0 organismo fisiológico é essencial a ele, mas nós somos ao menos capazes de imaginar um self sem o organismo fisiológico. Pessoas que acreditam na imortalidade, ou que acreditam em fantasmas, ou na possibilidade de o self deixar o corpo, pressupõem um self bem distinto do corpo. Como essas pessoas conseguem manter essas concepções de forma bem-sucedida é uma questão aberta, mas, de fato, separamos o self e o organismo. É justo dizer que o começo do self como um objeto, tanto quanto podemos ver, pode ser encontrado na experiência das pessoas que têm a concepção de um duplo. ${ }^{170}$

Desse ponto de vista, Mead propôs uma explicação coerente para um conjunto significativamente grande de crenças em que se percebem almas, espíritos e duplos, dentre outros fenômenos semelhantes. Seria exatamente a possibilidade de tomar 


\section{Individuação}

a si mesmo como personagem de uma narrativa autobiográfica feita em tempo real que induziria a esse tipo de crença. Porque não se poderia pensar em alucinação mundialmente coletiva, o autor, aparentemente por cautela, propôs deixar a questão em aberto.

Hume (2009) propunha que o self se formasse pela comparação entre as percepções atuais e a as memorizadas, o que formaria uma sequência de causas e consequências tomada como uma unidade. Mead, entretanto, separa as percepções do self. Para ele, seria possível deixar que o corpo agisse separadamente do self.

Quando alguém está correndo para longe de outro que o está caçando, está totalmente preocupado com essa ação, e sua experiência pode ser absorvida pelos objetos em volta dele, de maneira que ele não tenha, nesse momento, absolutamente nenhuma consciência de si mesmo. Precisamos estar, de fato, totalmente ocupados para que isso ocorra dessa maneira, mas podemos, creio, reconhecer esse tipo de experiência em que o self não toma parte. ${ }^{171}$

Desse ponto de vista, o corpo poderia atuar sem a participação do self e, como ele próprio afirmou, o corpo "pode operar de maneira bem inteligente". 0 self, entretanto, não poderia operar de forma independente. A hipótese principal é a de que o self tem uma origem especialmente social.

O indivíduo experiencia a si mesmo, não direta, mas indiretamente tanto de pontos de vista 
particulares em relação aos outros indivíduos membros do mesmo grupo social, como de um ponto de vista generalizado do grupo social como um todo, ao qual ele pertence. Porque ele entra em sua própria experiência como um self ou indivíduo, não direta ou indiretamente, não por tornar-se um sujeito para si mesmo, mas apenas na medida em que ele se torna um objeto para si mesmo, da mesma maneira que os outros indivíduos são objetos para ele ou para sua experiência; e ele se torna objeto para si mesmo somente por tomar as atitudes dos outros indivíduos que eram dirigidas a ele em um ambiente social, em cujo contexto de experiências e de comportamento todos estão envolvidos. ${ }^{172}$

Desse ponto de vista, essa proposta se diferenciaria das anteriores, na medida em que entenderia o indivíduo a partir de uma autorrepresentação, retomando a noção de teatro proposta por Hume (2009).

A importância do que chamamos de comunicação associa-se ao fato de ela apresentar uma forma de comportamento no qual o organismo ou o indivíduo pode tornar-se objeto para si mesmo. [...] Na medida em que esse tipo de comunicação [dirigida não somente aos outros, mas para o próprio indivíduo] é uma parte do comportamento, ela introduz finalmente um self. [...] Mas, é quando se responde à pergunta dirigida ao outro e quando essa resposta à sua própria pergunta torna-se uma parte de sua conduta, quando não apenas se ouve a si mesmo, mas também se responde a si mesmo, fala e retruca a si mesmo como se fosse verdadeiramente outra pessoa respondendo, é 


\section{Individuação}

que temos um comportamento em que os indivíduos tornam-se objetos de si mesmos. ${ }^{173}$

Mead (1962) trouxe o self inteiramente para dentro da linguagem, tratando-se, pois, de um fenômeno desenvolvido a partir das relações sociais que o indivíduo desenvolve durante sua vida. Ele tomou o self como "algo que tem um desenvolvimento, que não está lá desde o início, no nascimento; mas origina-se nos processos das experiências e das atividades sociais". ${ }^{174}$ Ainda que seja uma proposta bastante contraintuitiva, o próprio self seria tratado, portanto, como um fato social, isto é, como um fato simbólico, de maneira semelhante, como vimos, aos status/papéis que um indivíduo acumula durante sua vida. Assim, a noção de self estaria sujeita às mesmas características do conjunto de crenças que formam o senso comum.

Um indivíduo que faça parte de uma sociedade que entende que as pessoas se compõem de duas almas e que uma, a espiritual, que é fugaz, tem o poder de controlar a outra, a telúrica, que é imanente, avalia-se dessa forma e mantém uma preocupação constante na manutenção de sua espiritualidade, caso queira poder controlar-se. Para tanto, seria necessário conhecer suas almas quanto à origem divina e quanto à natureza. Saber-se nominado por Karaí e ser portador de uma alma semelhante à dos tapires, tanto pode levar ao heroísmo como à imprudência suicida. Trata-se especialmente de o indivíduo saber reconhecer o controle que tem 
sobre sua alma telúrica, pela falta de sua alma espiritual. 0 heroísmo, nesse caso, exigiria uma espiritualidade completa, movida pelo arrebatamento próprio de sua alma telúrica. Conhecer-se, portanto, seria conhecer os animais, os deuses, os nomes... De forma semelhante ao fato de se conhecer desse ou daquele gênero, porque se recebe, por exemplo, um nome próprio que faz parte de um conjunto de nomes característicos de um gênero e se é avaliado socialmente pelo desempenho do papel referente a esse gênero, a formação do self, também depende dos sinais externos que são apresentados socialmente aos indivíduos. Ao assumir o status, o indivíduo passa a desempenhar seu papel correspondente, seja quanto a seus comportamentos sociais seja quanto a sua própria avaliação subjetiva.

Stuart Hall (1932-2014), tomando sua própria experiência, descreveu o processo de tornar-se alvo da atribuição de status.

[...] passei por um longo e importante ensinamento político até descobrir que sou "negro". Constituir-se como indivíduo "negro" é um outro reconhecimento do "eu" por meio da diferença - certos extremos e polaridades claros em contraposição aos quais se busca uma autodefinição. Constantemente subestimamos a importância, para certos fatos políticos cruciais que ocorreram no mundo, dessa capacidade que as pessoas têm de se constituírem, psiquicamente, em identidade negra. Há muito tempo se acredita que esse processo é realmente 


\section{Individuação}

simples: um reconhecimento - uma resolução de irresoluções, um vir a descansar em algum lugar que sempre esteve ali nos esperando. 0 "eu real", finalmente.

0 fato é que a identidade "negra" nunca teve exatamente o seu lugar. Tem sido sempre uma identidade instável, tanto no aspecto psíquico como cultural e político. Essa identidade também é uma narrativa, uma estória e uma história. É algo construído, falado, contado, e não apenas encontrado. Hoje as pessoas se referem à sociedade de onde venho de formas totalmente irreconhecíveis. É claro que a sociedade jamaicana é uma sociedade negra, diz-se. $\mathrm{Na}$ verdade, é uma sociedade de indivíduos negros e pardos que passaram trezentos ou quatrocentos anos sem jamais poder se referir a si próprios como sendo "negros". A identidade "negra" precisou ser aprendida, e só pode fazê-la num determinado momento. $\mathrm{Na}$ Jamaica esse momento foi a década de 70.175

Com praticamente a mesma formação discursiva dos status definitivos, como o sexo e a nacionalidade, Hall (1997/1998) estabelece que o status atribuído negro é uma das crenças que atua diretamente no senso comum. Tornar-se negro decorre de um fato social coercitivo que ultrapassa as fronteiras da própria sociedade. A atribuição advém de uma sociedade sobre outra - no caso específico, a sociedade inglesa atribuindo status à sociedade jamaicana - o que, por extensão, atinge a todos os indivíduos que formam a sociedade alvo. Assim, ainda que em sua própria sociedade a cor da pele não seja observada periscopicamente, ela o é 
pela sociedade inglesa que atribui aos indivíduos oriundos de uma sociedade tratada como "de negros" o status correspondente.

Na medida em que os status e papéis seriam fatos sociais, caberia à própria sociedade a responsabilidade de oferecer as condições necessárias para que os indivíduos pudessem adquiri-los para, então, desempenhá-los adequadamente. No entanto, conforme também já vimos no segundo capítulo, quando discutimos o senso comum, essas condições não são oferecidas para todos. A possibilidade de aquisição de status, por si só, não é garantia de desempenho de papéis. A mudança de status atribuído de "trabalhador cativo" para "trabalhador livre", no final do século XIX, no Brasil, deveria ter como consequência a igualdade de condições para o ex-escravo no mercado de trabalho. Soares (2000) procurou verificar a distribuição salarial entre mulheres e homens negros e mulheres brancas, em relação ao salário de homens brancos, nos anos que vão de 1987 até 1998 . Os resultados que obteve mostraram que o salário de homens negros era em 1987, em média, $47 \%$ do salário de homens brancos; o das mulheres negras era 33\% e o das mulheres brancas, $68 \%$. Praticamente dez anos depois, o salário de homens negros era $46 \%$ do salário de homens brancos; o das mulheres negras, $40 \%$ e o das mulheres brancas, 79\%. Essa diferença é significativa, não só porque aponta uma distinção de gênero, isto é, homens recebem salários maiores do 


\section{Individuação}

que mulheres, como também indivíduos brancos recebem salários maiores do que negros. 0 aumento de sete pontos percentuais na média salarial de mulheres negras em relação à média salarial de homens brancos e de 11 pontos percentuais na relação entre a média salarial de mulheres brancas e de homens brancos aponta para o fato de que houve uma preocupação com a questão de gênero. Em relação à variação da média salarial de homens negros e homens brancos, houve uma queda de um ponto percentual, apontando para o congelamento dessa relação entre médias salariais. Uma vez que estamos lidando com uma situação distante em mais de um século do período escravagista, cujas vítimas eram especialmente a população negra, seria de se esperar que essa desigualdade tivesse sido resolvida e que as oportunidades salariais fossem comuns a todos, independentemente de gênero e cor de pele. Campante e seus colegas (2004) corroboram esses dados, mostrando que na região sudeste brasileira, de que tratamos no primeiro capítulo, a relação entre a cor da pele e o mercado de trabalho, refletida na disparidade das médias salariais entre brancos e negros, pode receber uma interpretação diretamente associada às crenças próprias do senso comum.

[...] se o sistema de crenças do empregador diz que trabalhadores negros são menos produtivos do que os brancos, então, este mesmo empregador só contratará negros se o salário deles for menor do que o salário dos brancos. Assim, é como se no Sudeste os empregadores tivessem um sistema de crenças que apontasse a 
educação dos negros como sendo inferior, de menor qualidade. ${ }^{176}$

A mudança no status do trabalhador negro, de "cativo" para "livre", embora positiva, não foi suficiente para que o status "livre" atribuído socialmente aos indivíduos criasse igualdade de condições no desempenho de papéis relativos a seus status profissionais adquiridos. O status de "negro" que obrigava o indivíduo a ser "cativo" passou a obrigar o indivíduo a receber salários mais baixos, independentemente do esforço pessoal dedicado ao status profissional que adquira.

Numa universidade bastante prestigiosa do estado de São Paulo, em que a população autodeclarada como preta ou parda, de um lado, e branca, de outra, tem distribuição de 38\% e 62\% respectivamente, conforme dados de 2010 do IBGE, teve 21\% de pretos ou pardos, e 79\% de brancos (ou amarelos) inscritos para o vestibular de 2016. Na medida em que não há razão para se pensar que houve um decréscimo na população preta ou parda no estado, a diferença de 17 pontos percentuais entre a distribuição da população preta ou parda no estado e a distribuição de inscrições no vestibular tem de ser atribuída à falta de perspectiva de sucesso da própria população autodeclarada preta ou parda para fazer essa tentativa. Da mesma maneira que o self proposto por Mead (1962) decorreria da autorrepresentação, definida socialmente na forma de status e papéis sociais, a perspectiva negativa de ingresso numa universidade prestigiosa decorre, 


\section{Individuação}

nesse caso, de uma autoavaliação também negativa instituída subjetivamente a partir da própria sociedade; para usar as palavras de Mead (1962), repetimos o trecho já citado anteriormente, em que ele afirma que o indivíduo "se torna objeto para si mesmo somente por tomar as atitudes dos outros indivíduos que eram dirigidas a ele em um ambiente social, em cujo contexto de experiências e de comportamento todos estão envolvidos".

O self, para Mead (1934), assim como ser negro, para Hall (1997/1998), ou ser mulher para Tubert (1996), ou ser brasileiro, para Fiorin (2009), também é um fenômeno discursivo.

Eu não sei de nenhuma outra forma de comportamento além do linguístico no qual o indivíduo possa ser objeto para si mesmo e, tanto quanto eu possa ver, o indivíduo não é um self no sentido reflexivo a menos que ele seja um objeto para si mesmo. É esse fato que dá a importância fundamental da comunicação, pois é um tipo de comportamento em que o indivíduo responde para si mesmo. 177

Seguindo essa mesma linha de raciocínio, Benveniste (1976) é quem oferece argumentos mais propriamente linguísticos que corroboram as propostas anteriores. Benveniste propôs que seria a própria forma linguística dos pronomes que estabeleceria a possibilidade de os indivíduos tomarem a si próprios como sujeitos.

A consciência de si mesmo só é possível se experimentada por contraste. Eu não emprego eu a não ser dirigindo-me a alguém, que será na 
minha alocução um tu. Essa condição de diálogo é que é constitutiva da pessoa, pois implica em reciprocidade - que eu me torne tu na alocução daquele que por sua vez se designa por $e u$. Vemos aí um princípio cujas consequências é preciso desenvolver em todas as direções. A linguagem só é possível porque cada locutor se apresenta como sujeito, remetendo a ele mesmo como eu no seu discurso. Por isso, eu propõe uma outra pessoa, aquela que, sendo embora exterior a "mim", torna-se o meu eco - ao qual digo tu e que me diz $t u .{ }^{178}$

Nesse sentido, em que ocorrem os pronomes "eu" e "tu", bem como todas as formas linguísticas portadoras de suas dêixis, a formação discursiva do self decorreria da instauração da segunda pessoa, o "tu" como um interlocutor no diálogo: é o outro que ouve e que participa ativamente das manifestações do sujeito que usa a linguagem naquele momento. Conforme as ideias de Mead (1934) de que já tratamos, seria somente quando couberem no mesmo indivíduo as dêixis de primeira e de segunda pessoa que se poderia entender o self como uma unidade psiquicamente constituída.

Proposição semelhante, mas aplicada às narrativas, foi desenvolvida por Gerard Genette (1971). Para esse autor, a oposição clássica entre a diegesis e a mimeses - respectivamente, o discurso narrativo indireto e o discurso imitativo direto, como nas transcrições de diálogos - não se poderia sustentar. A diferença entre o discurso direto e o indireto estaria na participação de um narrador. Numa peça de teatro, por exemplo, em que somente 


\section{Individuação}

as personagens falam, teríamos uma situação de mimeses, uma vez que os atores estariam imitando o que poderia ser uma situação real. Se houvesse um narrador, não haveria imitação, pois o narrador apenas relataria o ocorrido, sem procurar imitá-lo. Obviamente haveria situações intermediárias, mas que não serão discutidas aqui. 0 argumento de Genette (1979) para questionar essa oposição clássica baseou-se na narrativa ficcional. Segundo o autor, a mimeses só teria sentido se houvesse diferença entre o logos e a lexis, isto é, entre o fato que se narra e a forma linguística usada para narrá-lo. 0 logos seria o conjunto dos fatos que vão representados pela linguagem, que é a lexis. Um diálogo numa peça teatral constitui-se numa lexis, em que o logos seria criado por ela própria. Um diálogo real se constituiria num logos e numa lexis ambos reais, pois não se trataria de uma imitação de diálogo. Uma vez que na narrativa de ficção não há um logos que se imite, ele tem de ser criado pela própria lexis, ou seja, a linguagem é que cria os fatos que ela representa. Dessa forma, no discurso direto, os diálogos deixam de ser imitações e passam a ser representações, tais como no discurso indireto da diegesis. Genette (1971), com esse argumento, demonstra não haver diferenças entre mimeses e diegesis. $\mathrm{O}$ autor, entretanto, deixa uma porta aberta para a mimeses, salientando que, no discurso jurídico, por exemplo, quando se apresenta uma prova concreta de algum fato em julgamento, há um discurso misto com diegesis e mimeses diferenciadas. 
Da mesma maneira que as narrativas de ficção, em que não há um real a se representar, mas é o próprio discurso que cria os fatos representados, as narrativas pessoais podem ser elas próprias tomadas como matrizes dos fatos que representam. Assim, as experiências pessoais narradas que se fixaram pelo método da tenacidade peirciano são representações do passado que se implementaram com inserções cumulativas da memória coletiva. Com isso, as experiências pessoais se tornam fatos discursivos sujeitos às habilidades discursivas próprias de cada indivíduo.

Como se verá no próximo capítulo, a comunicação linguística entre indivíduos pode ser interpretada pela definição de dois polos: um que produz e outro que aceita. Embora esse modelo já tenha recebido diferentes propostas de atualização, de maneira geral, o princípio básico é sempre a dualidade dos interlocutores. Na teoria da comunicação, por exemplo, fala-se em emissor e em receptor; ${ }^{179}$ na teoria da enunciação, fala-se em locutor e alocutário; ${ }^{180}$ ou em enunciador e enunciatário. ${ }^{181}$ Apesar de estarmos falando em dualidade, nada impede que tais polos sejam plurais, e que o enunciador seja um sujeito plural e o enunciatário também.

Benveniste (1974), no quadro em que definiu "enunciação", distinguindo "locutor" de "alocutário", propôs que o locutor fosse a figura enunciativa que atuaria como o ponto de convergência de todas as referências. Linguisticamente, ele se manifestaria 


\section{Individuação}

como o "eu" e poderia ser localizado em todas as formas em que essa dêixis de primeira pessoa estivesse presente. 0 alocutário, por sua vez, se manifestaria pelos termos que referem a dêixis de segunda pessoa, "tu”, caracterizado, sempre, a partir da primeira pessoa. Genette apresentou um argumento forte o suficiente para dividir a figura enunciativa do locutor benvenistiano em "locutor" e "narrador." 182 O argumento apresentado foi o mesmo que já havia utilizado quando propôs que os conceitos de diegesis e de mimesis se confundiriam se fossem aplicados à narrativa ficcional. Genette chamou a atenção para o fato de que numa narrativa ficcional não se poderia pressupor que as formas linguísticas que contivessem dêixis de primeira pessoa estivessem relacionadas com a instância enunciativa do momento de produção escrita ou oral da narrativa. Esses termos se reportariam especialmente à figura do narrador. Genette separou narrador, como figura própria da instância narrativa, e autor, como figura própria da instância do ato de produção escrita ou oral da narrativa. Segundo ele, ainda que tais figuras pudessem alinhar-se, atuariam em instâncias enunciativas diferentes, podendo desalinhar-se sem dificuldade. 0 alinhamento entre o narrador ou a personagem decorreria, portanto, de se estar tratando de um discurso ficcional ou não. Conforme vimos, a diferenciação entre logos e lexis implicaria que poderia haver um discurso em que a lexis criaria o logos, isto é, o pronome "eu", no discurso, não se reportaria a nenhuma figura existente, mas seria 
tão-somente imaginada pelo próprio interlocutor desse discurso. Mas, se não for um discurso ficcional, o pronome se reportaria ao autor desse discurso.

Estabelecendo uma instância intermediária entre o autor e o narrador, Erving Goffman (1922-1982), ao propor a noção de footing, chama a atenção para o desalinhamento possível entre quem seleciona os sentimentos e as palavras que os codificam e quem efetivamente as pronuncia por exemplo em traduções simultâneas, leituras ou recitais de textos memorizados, como fazem atores em peças teatrais.

Agora é necessário examinar o elemento restante do paradigma conversacional, a noção de falante.

Em uma conversa padrão, um dos dois participantes move seus lábios para cima e para baixo, acompanhando seus próprios movimentos faciais (e algumas vezes corporais), e palavras podem ser ouvidas, emitidas do ponto exato da sua boca. É sua caixa sonora em uso, embora em alguns casos ele possa compartilhar essa função físicas com um sistema de alto-falantes ou um telefone. Em suma, ele é a máquina de falar, um corpo envolvido numa atividade acústica ou, se quiserem, um indivíduo engajado no papel de produzir elocuções. Ele está funcionando com um "animador". 183

Desse ponto de vista, Goffman tomou "animador" especialmente como o falante, o indivíduo que dá forma material ao discurso. Trata-se necessariamente, por sua própria natureza, de uma figura que deve ter existência real, ainda que, como ele mesmo disse, possa ser complementado, e até 


\section{Individuação}

substituído, por uma tecnologia auxiliar, como alto-falantes, ou gravadores, filmagens, ou pela participação de outros indivíduos como é próprio em jograis e nos jornalismos radiofônicos e televisivos. Ainda seria possível que esse procedimento ocorresse pela modalidade manuscrita ou pela impressão massiva de texto escrito, dentre muitas outras possibilidades. Seja como for, a figura do falante de Goffman não se confunde com a de autor ou com a de responsável.

Algumas vezes considera-se que há um "autor" das palavras que são ouvidas, ou seja, alguém que selecionou os sentimentos que estão sendo expressos e as palavras nas quais eles estão codificados.

Às vezes, considera-se que um "responsável” (em termos legais) está envolvido, ou seja, alguém cuja posição é estabelecida pelas palavras faladas, alguém cujas opiniões/crenças são verbalizadas, alguém que está comprometido com o que as palavras expressam. Note que, nesse caso, não se lida tanto com um corpo ou mente, mas sim com uma pessoa que ocupa algum papel ou identidade social específica, alguma qualificação especial como membro de um grupo, posto, categoria, relação, associação ou qualquer fonte de auto identificação socialmente referenciada. ${ }^{184}$

Nesse caso, trata-se de uma hipótese que se coaduna com a de Austin ${ }^{185}$ em que o responsável seria o sujeito que cumpre todas as prerrogativas sociais que lhe autorizam a fazer-se autor de enunciado performativo válido. $\mathrm{O}$ autor, apesar de ser figura do 
mundo real, não precisa estar necessariamente visível, audível, pois esse papel caberia ao locutor ${ }^{186}$ - o "animador" de Goffman. Entretanto, o autor tem de ser imaginado pelo interlocutor como se fosse o próprio locutor, inclusive substituindo-o idealmente. Essa é uma das condições necessárias mais importantes para a credibilidade da enunciação. É o caso, por exemplo, de maus atores, cuja atuação não nos convence de que se trata da personagem mesmo e não de um sujeito que finge ser outra pessoa, fazendo caretas e trejeitos inadequados para o papel que está tentando representar. 0 que ocorreu, nesse caso, foi que o ator se tornou saliente, com visibilidade maior do que a que deveria ter sido imaginada pelo interlocutor, que tomaria o autor como a própria personagem. Esse é um fato corriqueiro que será mais bem desenvolvido no próximo capítulo quando tratarmos do modelo simbólico de Peirce.

A proposta de Goffman, associada à de Genette, permite-nos tomar as figuras que atuam na enunciação a partir do texto, isolando o narrador e as personagens como figuras exclusivamente linguísticas, e a partir da enunciação, isolando o ator - o animador de Goffman, ou mais propriamente, o locutor - e o autor como figuras exclusivamente extralinguísticas. A diferença entre narrador, no discurso indireto, e personagens, no discurso direto, é apenas uma questão de estilo, na medida em que não há discurso direto que não possa ser convertido em indireto e vice-versa. No caso de autor e locutor, 


\section{Individuação}

as diferenças entre eles são significativas. $\mathrm{O}$ autor pode alinhar-se com a figura do locutor, falando um texto de sua autoria, seja em tempo real, como improviso, seja a posteriori, como discurso preestabelecido. Em ambos os casos, o autor é o próprio locutor de seus textos. No entanto, como é comum, o autor pode ser desconhecido, como ocorre quando se conta uma história anônima, ou quando se lê um texto cuja autoria não vai ali marcada. 0 autor pode estar morto, pode ser um grupo de pessoas e pode, mesmo, ser parcialmente o próprio locutor em coautoria com outro qualquer que não está lá. Uma narrativa pessoal autobiográfica pressupõe que todas as três figuras estejam alinhadas: autor locutor e narrador - como uma mesma figura. Na maior parte das vezes, entretanto, esse alinhamento não se mantém homogêneo durante a enunciação.

Desse ponto de vista, os usuários da língua têm dois acessos à enunciação fisicamente: o primeiro é o texto propriamente dito, por meio do narrador, o segundo é a imagem/sensação que temos, seja acústica e/ou visual, por meio do locutor. Ambos os acessos são simultâneos e exigem que sejam apreendidos simultaneamente pelo interlocutor para que a enunciação ocorra. A enunciação é gerada pelo interlocutor ao considerar essas duas figuras enunciativas simultaneamente. Será somente a partir dessa dupla depreensão que as figuras do enunciador e do narrador poderão ser induzidas. Geralmente o interlocutor alinhará locutor e narrador, imaginando-os como uma coisa só. E 
disso resultará a possibilidade de manipulação que pode ser feita pelo autor. Em relação ao locutor, o que dá vida à enunciação, produzindo-a como fenômeno material, sua relação com o autor é inteiramente definida pelas suas relações extratextuais. A princípio será importante estabelecermos alguns parâmetros que possibilitem o reconhecimento do locutor na enunciação.

O locutor não precisa ser, necessariamente, o autor de seus enunciados. Muito embora o alinhamento entre essas figuras seja corrente, o interlocutor tende a acentuar esse alinhamento. Dessa maneira, é possível valer-se disso para um grande número de atos alocutários. Um exemplo fácil é o das propagandas para a venda de produtos, quando é feita por algum ator ou atleta famoso, admirado pelo público que faz a interlocução com a propaganda. Esse público tende a fazer o alinhamento entre $o$ locutor e o autor, presumindo que o enunciado seja verdadeiramente um conselho daquele herói famoso, sempre cheio de boas intenções. 0 desalinhamento entre autor e locutor é também facilmente percebido na leitura em voz alta. Salienta-se, pois, que é função precípua do locutor, e não do autor, estabelecer a prosódia - entendendo-a aqui como ritmo, entoação, pausas e intensidade, podendo haver outros elementos, mas não a cadeia segmental gerada pelo léxico (isso será visto mais adiante) para aquela enunciação. Numa leitura em voz alta que se faça de Machado de Assis, a prosódia é do leitor porque ele é o locutor daquele enunciado. A 


\section{Individuação}

prosódia de Machado de Assis ocorreu somente naquele momento em que o próprio Machado fez aquela enunciação. 0 interlocutor, entretanto, precisa continuar com a ilusão de que locutor e autor estão alinhados. Se a prosódia falha na leitura e o interlocutor se dá conta do desalinhamento, todo o aparelho formal da enunciação se desfaz.

Não há motivo para que tais figuras não se multipliquem horizontalmente. Pode haver muitos autores e muitos enunciadores para um mesmo texto. Na medida em que tanto narrador quanto personagens são ambos igualmente personagens, cabendo a diferença somente quanto à forma de tratamento estilístico que recebem, pode haver multiplicação horizontal e vertical de todos eles. Um diálogo será necessariamente composto por dois narradores, por exemplo, um monólogo por um só. No entanto, não há como não haver todas essas figuras enunciativas no texto enunciado. 0 mesmo se dirá do leitor. 0 desaparecimento dessas figuras decorre tão-somente do alinhamento que se faz delas.

Retomando a proposta de Mead (1962) de que seria somente a partir do comportamento linguístico que o indivíduo poderia ser objeto para si mesmo, podemos tomar as narrativas, dentre outras formas de expressão linguística disponíveis, como uma das estratégias possíveis para a configuração discursiva do self. 
Waldemar Ferreira Netto 


\section{Formação simbólica}

De uns tempos a esta parte, o estudo da capacidade cognitiva humana tem recebido uma atenção especial. Um dos aspectos dessa capacidade que merece atenção especial é seu caráter simbólico. Assim, paralelos aos estudos que buscam descrever diretamente o comportamento neurocognitivo, há que se descrever sua contrapartida simbólica, ou perceptiva. 0 uso de uma linguagem é a contrapartida mais evidente. Na medida em que se forma por conjuntos de representação simbólicas definidas socialmente e por regras de associação definidas, minimamente pela natureza humana, mas na sua maior parte pelas próprias convenções sociais, a linguagem é especialmente o objeto que merece maior compreensão quanto a seu caráter simbólico. Dentre as mais diferentes linguagens, a língua tem sido tomada como um dos principais meios de contato entre os indivíduos de uma mesma sociedade. Seu caráter simbólico é evidente por si só.

0 presente capítulo tem por objeto fazer a comparação entre as principais proposições de símbolo que foram feitas até agora. Para tanto, serão abordadas as proposições de Sexto Empírico, Humboldt, Peirce, Frege, Pavlov, Saussure, Watson, Shannon e Jakobson, entendendo-as como algumas das que mais influenciaram os estudos do simbolismo até hoje. Uma comparação dessa natureza poderá estabelecer novas hipóteses para a 
abordagem cognitiva humana, na medida em que, como se verá, vários aspectos dos símbolos são abordados a partir de recortes teóricos diferentes. Tais diferenças teóricas, por tentar descrever o mesmo fenômeno, coerem em vários pontos entre si e ainda nos permitem perceber que determinados aspectos podem ser reorganizados hierarquicamente para se adequar aos usos linguísticos, especialmente no que diz respeito às grandes unidades simbólicas.

O estudo da materialidade da língua, seja a que vai expressa por meio de imagens, seja a que vai expressa por meio de sons vocais, não prescinde da consideração de que tais formas de expressão só se caracterizam como fatos linguísticos se interpretados sob a ótica das manifestações simbólicas humanas. Ainda que, por meio de análises acústicas, seja possível analisar os sons da fala, isso não caracterizaria um estudo linguístico, mas tão somente um estudo acústico, semelhante ao que se faz com quaisquer outros sons da natureza. Os sons da fala só nos interessam no contexto de seu uso como símbolo. Desse ponto de vista, a interpretação do símbolo é fundamental para a compreensão dos sons da fala.

Ainda que esse estudo não tenha uma preocupação historiográfica, podemos localizar na tradição das discussões linguísticas algumas das primeiras hipóteses que se teve sobre a natureza dos símbolos usados na linguagem. Nos anos setenta, Todorov 


\section{Formação simbólica}

(1939-2017) fez um levantamento minucioso dessas hipóteses. ${ }^{187}$

Uma dessas hipóteses é a dos estoicos, que foi retomada e divulgada por Sexto Empírico. Segundo ele, o signo seria formado por um significante (semaînon), um significado (semainómenon) e por um objeto (tynchánon). Desses elementos, dois - o significante e o objeto - seriam corporais e um - o significado - seria incorporal. Esse significado incorporal estaria associado nessa hipótese à ideia de lektón. Maria Helena de Moura Neves (1987), referindo-se à mesma passagem de Sexto Empírico, disse que o lektón é "o que há de espiritual no som, aquilo que é designado por ele, que não é, porém, simplesmente, a representação que o objeto da percepção provoca na mente (phantasía)". ${ }^{188}$ Mais adiante, ela completou "sem ele [o lektón], haveria um simples som, sem conexão com o referente (tynchánon); não haveria léxis como elemento significante (semaînon)". ${ }^{189}$ Desse modo, é possível encontrar logo no início da era cristã uma hipótese de símbolo que o considerava formado por três elementos específicos: dois corpóreos e um incorpóreo, como já dissemos.

Dizem os estoicos que três coisas estão ligadas: o significado, o significante e o objeto. Dessas coisas, o significante é o som, por exemplo, "Dion"; o significado é a coisa mesma que é revelada e que apreendemos como subsistente na dependência do nosso pensamento, mas que os bárbaros não compreendem, embora sejam capazes de ouvir a palavra pronunciada; ao passo 
que o objeto é o que existe no exterior; por exemplo, Dion em pessoa. Duas dessas coisas são corporais: o som e o objeto, enquanto uma é incorporal, a entidade que é significada, o dizível (lekton) que é verdadeiro ou falso. 190

Ao falar do lektón, Sexto Empírico propôs que a característica simbólica de ser verdadeiro ou falso seria própria somente do próprio lektón, que é incorpóreo. 0 autor descarta, dessa maneira, o significante e o objeto de receber esse tipo de avaliação. Usando as palavras de Moura Neves (1987), somente o que há de "espiritual" no símbolo é que poderia ser avaliado. Pode-se entender por "espiritual" o fato de ser um elemento produzido pelo próprio homem e, portanto, não natural. Como Richard Rorty diria muitos séculos depois, a natureza não pode ser avaliada usando-se dos critérios de verdadeiro ou falso.

A verdade não pode estar dada - não pode existir
independentemente da mente humana - porque
as frases não podem existir dessa maneira, ou
estar aí. O mundo existe, mas não as descrições
do mundo. Só as descrições do mundo podem ser
verdadeiras ou falsas. O mundo em si - sem o
auxílio das atividades dos seres humanos - não
pode sê-lo. ${ }^{191}$ Assim, Sexto Empírico estabeleceu/divulgou uma diferença entre os próprios elementos formadores do símbolo tanto a partir do critério da sua materialidade, quanto do ponto de vista de sua possibilidade de submeter-se a teste de falsidade. Se a relação estabelecida entre dois elementos 


\section{Formação simbólica}

corpóreos poderia ser falseada, então eles comporiam um signo. Se não puder ser falseada, não haveria o que se afirmar a respeito dessa relação.

No século XVIII, George Berkeley (1685-1753) fez algumas proposições que podemos entender como um esboço de teoria do símbolo. Ao tratar do conhecimento humano, ele tratou das palavras como fenômenos que se associariam a ideias e estas a estímulos incidentes em nosso corpo.

Por meio da visão tenho as ideias da luz e das cores em seus diversos graus e variações. Por meio do tato percebo, por exemplo, duro e macio, calor e frio, movimento e resistência e, de todos esses, a diferenças em relação à quantidade ou ao grau. $\mathrm{O}$ olfato proporciona-me odores; o paladar, sabores; o ouvido leva à mente sons em toda a sua variedade de tom e de composição. E, quando se observa que várias dessas ideias se apresentam simultaneamente, elas passam a ser designadas por um nome e, dessa forma, a ser considerada uma coisa. ${ }^{192}$

O propósito de Berkeley (2010) não era a discussão sobre o símbolo, mas indiretamente ele acaba tratando disso. Separando as sensações dos nomes atribuídos a elas quando ocorressem simultaneamente e, finalmente, o reconhecimento como uma "coisa", o autor retomou o símbolo de Sexto Empírico. Quase que antevendo a argumentação de Pavlov no início do século $\mathrm{XX}$, como se verá mais adiante, Berkeley propôs que, a partir de estímulos externos, se desencadeariam sensações ou ideias que se permitiriam relacionar a um nome qualquer. 
Desse ponto de vista, têm-se, de um lado, pelos estímulos visuais, auditivos, táteis, etc., e pelo próprio nome que se atribui a isso as materialidades do símbolo bem definidas; de outro, sua subjetividade na forma de uma "coisa", definida pela percepção simultânea, as ideias, decorrente desses estímulos.

Esse mesmo esquema de três elementos dos signos, seria retomado por Friedrich Wilhelm Christian Karl Ferdinand Freiherr von Humboldt (1767-1835), conhecido como Wilhelm von Humboldt e, depois, por Charles Sanders Peirce e por Gottlob Frege.

A designação do conceito por meio do som é uma conexão de duas coisas cuja natureza jamais permitirá uma união verdadeira. E, no entanto, o conceito é tão incapaz de livrar da palavra como o homem de prescindir de seus traços faciais. [...] A união dessas duas naturezas diversas que são o conceito e o som, mesmo esquecendo por inteiro a vibração material deste último, precisa de um terceiro que se faça de mediador entre ambos em no qual ambos possam se encontrar. 193

A hipótese de Peirce retomou a de Sexto Empírico estabelecendo um signo com três elementos. Peirce, no entanto, discutiu sobre esses três elementos do signo fazendo, em dois momentos distintos, duas propostas. Na primeira ele falou em objeto (object), sentido (meaning) e interpretante (interpretant). ${ }^{194}$ Essa parece ser a primeira proposta. 0 autor entendia que o objeto é o que é representado, o sentido, o que o suporta e, finalmente, o interpretante, o que lhe dá lugar. Mais adiante, em seus escritos, ele 


\section{Formação simbólica}

refez essa terminologia; sua divisão tripartida do signo ficou então definida por um representamem que é o que pode ser usado em lugar de outra coisa - um objeto - que é o que foi substituído - e um interpretante - que é o efeito mental ou o pensamento gerado por essa substituição de um objeto por um representamem. ${ }^{195} \mathrm{Em}$ relação ao signo de Sexto Empírico, tanto o representamem quanto o objeto peircianos se aproximariam muito das noções de semaînon e do tychánon. A diferença, dificilmente depreensível, estaria exatamente no que Sexto Empírico chamou de incorpóreo: o semainómenon e o interpretante de Peirce. Este falou em pensamento e efeito mental, mas Sexto Empírico falou em "algo fixado na nossa mente", pela tradução de Moura Neves, ou, pela tradução de Todorov, "a coisa... que aprendemos como subsistente em nosso pensamento". Os dois autores retomaram a ideia de que a relação estabelecida entre dois elementos corpóreos teria de ser mediada por um elemento incorpóreo, aprendido e que subsistiria no pensamento.

Uma classe muito ampla e importante de caracteres triádicos [consiste de] representações. Uma representação é o caractere de uma coisa por meio do qual, para a produção de um certo efeito mental, ele pode ficar no lugar de outra coisa. A coisa que tem esse caractere eu chamo de representamem, o efeito mental, ou pensamento, seu interpretante, a coisa que ela representa, o seu objeto. ${ }^{196}$ 
Peirce, no entanto, ainda foi muito além dessa proposição de signo. Ele criou novas instâncias sígnicas, das quais nos interessa especialmente a que propunha uma diferença entre o que ele chamou de ícone, índice e símbolo. Este último recebeu também o nome de signo. Deixemos a discussão sobre índice para outra ocasião, para que possamos nos concentrar na formação do ícone. Para Peirce, um ícone era um representamem que quase se confundiria com o próprio objeto representado. Um dos exemplos que ele deu foi o do mapa de uma ilha, no qual, quando colocado sobre ela, haveria um ponto que, no chão da ilha, coincidiria exatamente com o mesmo ponto no próprio mapa. Ou ainda outro exemplo, como o de se usar, numa peça teatral, o próprio objeto para representar o objeto. Nesse último caso, um crucifixo, segundo o exemplo dele, seria usado para representar um crucifixo. Assim, o mesmo objeto poderia ser representamem e objeto a um só tempo de um mesmo signo. Sua proposição de ícone ainda se estenderia para um efeito totalmente inovador na proposição de signo. 0 representamem de um ícone não só poderia quase se confundir com o seu objeto, como ser, ele próprio, o objeto, caso o objeto não existisse. Assim, ele deu o exemplo do centauro. Ora, se centauro não existe, não há um objeto para ser representado. Nesse caso, o interpretante tomaria como objeto o próprio representamem, como no caso do crucifixo. 


\section{Formação simbólica}

O ícone é um representamem que preenche essa função em virtude de característica própria que possui, mesmo que o seu objeto não exista. Assim, a estátua de um centauro não constitui (é verdade) um representamem se não existir "esse tal de centauro". Se ainda assim ainda representa um centauro, é em virtude de seu formato; e o formato continuará a tê-lo, exista ou não o centauro. ${ }^{197}$

Essa concepção de símbolo tem um poder explicativo muito mais abrangente do que a mera concepção tripartida do signo. Na medida em que um representamem pode ser o seu próprio objeto e o interpretante continua como um elemento que subsiste no pensamento, a criação de novos signos com essa mesma característica decorre da capacidade de se criar o próprio representamem. Ou seja, será o bastante criar um representamem, pois o interpretante será sua decorrência natural.

Ainda que possamos estender essa capacidade criadora de signos para uma infinidade de figuras, tais como o Chupacabras, as sereias, os Yetis, o Mapinguari, os lobisomens, o Minotauro, o Mão Furada, os monstros marinhos, o Saci de Lobato e o de Brecheret, ou quaisquer outros monstros, é especialmente a criação de signos linguísticos que nos interessa.

Assim, o representamem Capitu 198 decorre de objetos linguísticos lexicais sintaticamente organizados, o interpretante é a personagem que subsiste em nosso pensamento. A diferença na formação do signo Capitu em relação à do signo Saci, ou do sino 
Yeti, está no representamem. 0 signo Capitu tem um representamem linguístico, o signo Saci e o Yeti têm um signo imagético.

Para se conhecer a Capitu deve-se ler o Dom Casmurro de Machado de Assis, para conhecer o Saci ou o Yeti, deve-se ver a imagem deles. Ou, então, ouvir contar as histórias que se conhecem sobre essas personagens todas, e deixar que os interpretantes se formem em nosso pensamento. Em alguns casos, o representamem linguístico não pode ser transformado em imagens, como é o caso da Mula Sem Cabeça que Solta Fogo pelas Ventas. Trata-se de uma expressão cujos itens lexicais sintaticamente organizados não poderiam formar uma imagem coerente. 0 interpretante, por sua vez, está lá, e se permite manipular de forma suficientemente adequada para formar-se como personagem de qualquer narrativa.

Em período concomitante ao de Peirce, Frege (1898) também propôs uma noção tripartida de signo. Para ele, o signo seria composto de um sinal [Zeichen], um sentido [Sinn] e uma referência [Bedeutung]. Era um modelo muito mais próximo do modelo de Sexto Empírico do que do de Peirce. Para ele, o sinal como o referente também seria material, sujeito à própria natureza, ao contrário do sentido, que seria um fenômeno próprio da linguagem.

A conexão regular entre o sinal [Zeichen], seu sentido [Sinn] e sua referência [Bedeutung] é de tal modo que ao sinal corresponde um sentido [Sinn] determinado, e ao sentido [Sinn], por sua 


\section{Formação simbólica}

vez, corresponde uma referência [Bedeutung] determinada, enquanto que a uma referência [Bedeutung] (a um objeto) não deve pertencer apenas um único sinal. 0 mesmo sinal [Sinn] têm expressões diferentes em diferentes linguagens, ou até na mesma linguagem. ${ }^{199}$

Apesar de Frege não dar definições estritas de seus conceitos, sua apresentação por meio de exemplos é bastante esclarecedora. Um de seus exemplos mostrou que o ponto de interseção de dois pares de retas com origem nos ângulos de um triângulo e final no ponto médio do lado oposto a esse ângulo é sempre o mesmo, ou seja, o ponto de interseção entre a reta $a$ e a reta $b$ é o mesmo que o ponto entre a reta $b$ e a $c$. Assim, embora as expressões "ponto de interseção entre a reta $a$ e a reta $b$ " e "o ponto de entre a reta $b$ e a $c$ " sejam diferentes, a referência das duas expressões é a mesma. Ou seja, os sentidos seriam diferentes, mas o referente seria o mesmo.

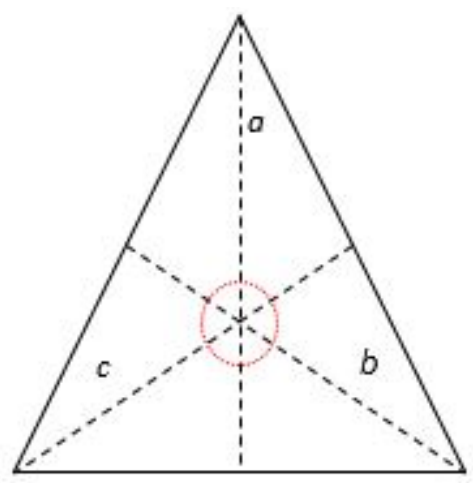


Sejam $a, b$ e $c$ as linhas que ligam os vértices de um triângulo com os pontos médios dos lados opostos, o ponto de interseção de $a$ e $b$ é, pois, o mesmo que o ponto de interseção de $b$ e $c$. Temos, assim, diferentes designações para o mesmo ponto; e estes nomes ("ponto de interseção de $a$ e $b$ " e "ponto de interseção de $b$ e $c$ ") indicam o modo de apresentação e, por consequência disso, a sentença contém um conhecimento real. ${ }^{200}$

Frege levou essa proposta adiante, mostrando que poderia ser aplicada não somente a expressões com referência conhecida, como o caso das expressões geométricas mostradas atrás. Ele apresentou o exemplo de uma expressão desconhecida: "o corpo celeste mais distante da Terra". Apesar de não se conhecer o referente, haveria um signo formado e um sentido devidamente estabelecido. Mesmo que o referente não existisse, como no exemplo "a série que converge menos rapidamente", que não teria referente, uma vez que, segundo ele, sempre existiria uma outra que convergiria menos rapidamente, seria um sinal que teria um sentido, mas não teria um referente. A descrição de Bedeutung, de Frege, para esse caso não é igual à noção de objeto de Peirce. Para Peirce, o objeto e o representamem seriam, nesse caso, o mesmo elemento; para Frege, simplesmente não haveria um Bedeutung. Para Peirce, o interpretante seria um efeito mental, um pensamento; para Frege, Sinn seria a maneira como se arranja o sinal. Assim, para Frege, as expressões $2+2$ e $1+3$ teriam o mesmo Bedeutung, mas Sinn diferentes. 


\section{Formação simbólica}

À semelhança da proposição de Peirce, Frege propôs que os símbolos possam ter ou não um Bedeutung associado. Segundo ele, seria o fato de não ter Bedeutung associado que permitiria considerar um enunciado como falso; definindo, pois, a condição de verdade de um enunciado como a presença de Bedeutung. Enunciados como "Ulisses profundamente adormecido foi desembarcado em Ítaca" (exemplo do autor) não teriam valor de verdade na medida em que o símbolo "Ulisses" não tem Bedeutung; seria uma enunciação de ficção, ou "obra de arte”, como ele chamou. Podemos pensar o mesmo da personagem Capitu, a que já nos referimos. Por não ter Bedeutung, sendo tão somente uma "obra de arte", qualquer discussão que se relacione ao Bedeutung será igualmente falsa ou fictícia; tanto quanto questionar como pode a Mula Sem Cabeça soltar fogo pelas ventas se ela não tem cabeça. Enunciados dessa natureza, segundo Frege, seriam Bild - traduzidos em português por "imagens". Segundo o autor, numa peça de teatro as falas e as palavras dos atores seriam somente Bild, assim como os próprios atores.

Essa noção de Bild, ou imagens, de Frege seria discutida por Bertrand Russel ${ }^{201}$ no início do século $\mathrm{XX}$. Para Russel, as imagens existiriam da mesma maneira que os objetos comuns existiriam. Segundo ele,

[...] se fecharmos os olhos e imaginarmos alguma cena visual, as imagens que estão diante de nossa mente enquanto estamos imaginando 
indubitavelmente aí estão. Elas são imagens, alguma coisa está acontecendo, e o que está acontecendo é que as imagens estão diante de nossa mente, e estas imagens são exatamente uma parte do mundo assim como o são as mesas, as cadeiras e qualquer outra coisa. ${ }^{202}$

A diferença entre imagens e objetos comuns decorreria somente da correlação entre a imaginação e os sentidos: essa correlação inexistiria no caso das ideias mas existiria no caso dos objetos comuns. Desse ponto de vista, as imagens seriam somente coisas que não se adequariam ao mundo físico. Essa proposição de Russel radicalizou o Bild de Frege, no sentido estrito de que poderia ser considerado componente simbólico. Entretanto, Russel não tomou esse conceito em uma proposição de símbolo, como Sexto Empírico, Peirce e Frege, deixando de esboçar uma teoria do símbolo mais completa, mas corroborando as hipóteses anteriores.

A semelhança desse conceito de Bild com o de ícone feito por Peirce é notável. Peirce, no entanto, fez uma diferença entre as partes do símbolo especialmente entre representamem e interpretante - que eliminava todo tipo de materialidade. Frege, por sua vez, manteve parcialmente a materialidade do Sinn, na medida em que o considerava também do ponto de vista da seleção e do arranjo de suas unidades componentes. 0 conceito de Bild, proposto marginalmente em nota de rodapé por Frege, estava além do Sinn, como a definir uma componente intermediária entre Sinn e 


\section{Formação simbólica}

Bedeutung. Assim, teríamos para Frege um símbolo composto por quatro elementos, quais sejam: Zeichen, Sinn, Bild e Bedeutung.

Essa mesma relação entre um fato físico, ou fisiológico, e um fenômeno psíquico, mental, no âmbito da representação material - do semaînon de Sexto Empírico, do Representamem de Peirce ou do Zeichen de Frege - apareceu esboçada também em Ivan Petrovich Pavlov (1849-1936), quando interpretou os dados do que ele mesmo chamaria de reflexo condicionado.

Segundo Pavlov (1903), o reflexo condicionado se desencadearia a partir da concomitância ou da precedência de um fenômeno qualquer em relação a um objeto de desejo, qual seja a comida. No caso de um som, por exemplo, sua antecipação à apresentação da comida, quando ocorresse repetidamente, terminaria por provocar a salivação, a despeito de a comida estar lá ou não. Não se trataria, entretanto, de qualquer som, mas de um som que se repetisse, mantendo sempre as mesmas propriedades, quaisquer que fossem. Poderia inclusive ser uma propriedade muito específica. Dessa maneira, esse processo estabeleceria uma sequência bem definida de associações criadas pela repetição e pela concomitância/antecipação. A primeira associação seria fisiológica (alimento $\rightarrow$ salivação), a segunda seria psíquica (visão do alimento $\rightarrow$ salivação) e a terceira, também psíquica (som associado à visão do alimento $\rightarrow$ salivação). 
Pavlov, em 1903, fez uma distinção clara entre fatos fisiológicos e fatos psíquicos de suas experiências.

[...] nos experimentos fisiológicos, o animal é excitado pelas propriedades absolutas, essenciais, do objeto, com relação ao papel fisiológico da saliva.

Nos experimentos psicológicos, são as propriedades dos objetos exteriores, sem importância para a função das glândulas salivares e, inclusive, completamente ocasionais, as que excitam o animal. ${ }^{203}$

Segundo ele, haveria uma seleção espontânea de propriedade, desencadeada pela simultaneidade inicial recorrente de propriedades essenciais e de propriedades sem importância dos objetos, que estabeleceria o que poderia atuar como estímulo no caso de um reflexo condicionado. Assim, dessa seleção, poderiam restar dos objetos somente uma cor, um tom, um timbre, dentre inúmeras possibilidades. Em particular, as propriedades sonoras são as que nos interessam. Pavlov iria ainda um pouco além em suas conjeturas, entendendo que a "reação salivar do animal poderia ser considerada, na vida subjetiva, como o substractum de uma imagem pura, elementar, isto é, como o substractum do pensamento". 204 Assim, a partir das propriedades essenciais dos objetos, como fatos fisiológicos, o reflexo condicionado se valeria de propriedades sem importância, mas recorrentes, como fatos psicológicos que estimulariam o reflexo salivar do animal, entendido, agora, como um possível substrato do pensamento. Pavlov (1903) diferenciou 


\section{Formação simbólica}

essa reação fisiológica involuntária do impulso que o animal teria para jogar-se sobre a comida. 0 estímulo fisiológico que provocou salivação do animal condicionou a intensidade da reação: alimentos secos provocam salivação mais intensa do que alimentos úmidos. No entanto, o impulso de jogar-se sobre o alimento seria o mesmo, a despeito do estímulo e da reação do reflexo condicionado. Pavlov (1903) estabeleceu como fenômenos sequenciais a reação salivar condicionada e o impulso de jogar-se sobre o alimento.

Numa passagem do Curso de Linguística Geral (CLG), atribuído à Ferdinand Mongin de Saussure (1857-1913) por seus alunos, há uma descrição da situação de comunicação que é chamada de Circuito da Fala, ou Circuite de la Parole, no original. Nesse circuito da fala participariam, como mínimo necessário, dois indivíduos.

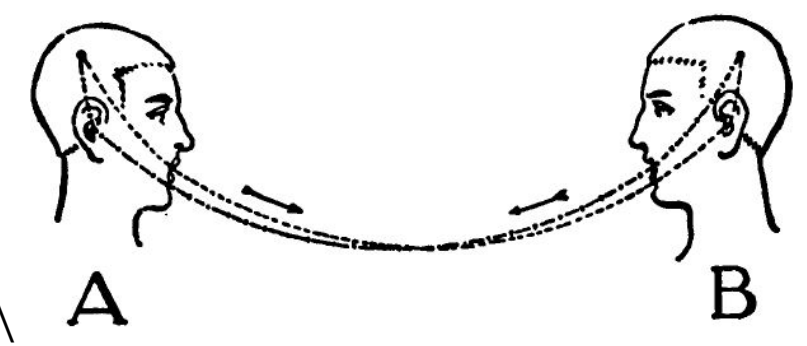

Suponhamos duas pessoas, A e B, que conversam. 0 ponto de partida do circuito se situa no cérebro de uma delas, por exemplo $\mathrm{A}$, onde os fatos de consciência, a que chamaremos conceitos, se acham associados às representações dos signos linguísticos ou imagens acústicas que servem para exprimi-los. Suponhamos que um dado 
conceito suscite no cérebro uma imagem acústica correspondente: é um fenômeno inteiramente psíquico, seguido por sua vez, de um processo fisiológico: o cérebro transmite aos órgãos da fonação um impulso correlativo da imagem; depois, as ondas sonoras se propagam da boca de $A$ até o ouvido de $B$ : processo puramente físico. Em seguida, o circuito se prolonga em B numa ordem inversa: do ouvido ao cérebro... ${ }^{205}$

Ainda que não faça alguma referência a símbolo, esse trecho do CLG retomou a proposição de Sexto Empírico de que fatos de consciência, ou conceitos, seriam fenômenos que subsistiriam na dependência do nosso pensamento. Havia também a proposta de que representações fossem tomadas como imagens acústicas.

A relação que se estabeleceria entre conceitos e imagens acústicas, ou entre fatos de consciência e representações, seria apenas tratada como uma associação: conceitos estariam associados a imagens acústicas; isto é, um "suscita" o outro. No original, o termo utilizado é déclanche, que também poderia ser traduzido como 'provoca, dispara, aciona'. Nessa proposta, não se esclareceu a maneira como os indivíduos converteriam um conceito numa imagem acústica e vice-versa. Um pouco mais adiante, propôs-se que, "na parte psíquica localizada no cérebro, pode-se chamar executivo tudo o que é ativo $(c \rightarrow i)$ e receptivo, tudo o que é passivo $(i \rightarrow$ $c)$ ". ${ }^{206}$ Por $(c \rightarrow i)$ entendemos que um conceito "c" desencadearia uma imagem acústica "i". Nesse caso, isso integraria a parte psíquica executiva. Na direção 


\section{Formação simbólica}

contrária, em que $(i \rightarrow c)$, entendemos que integraria a parte psíquica receptiva. Com essa proposta, podemos supor que seu modelo assumiria uma atividade produtiva e outra perceptiva da fala.

Ainda segundo o CGL, os processos executivos, $(c \rightarrow$ i), em que o estímulo inicial parte do conceito, seriam tomados como fenômenos sob o domínio indivídual do falante e, portanto, definiriam os atos de fala. Os processos receptivos, $(i \rightarrow c)$, em que o estímulo inicial parte da imagem acústica, seriam tomados como fenômenos sob o domínio da própria sociedade e, portanto, definiriam a língua, como um fato social. Do ponto de vista dessa proposta, o processo receptivo seria, além de passivo, alheio ao próprio indivíduo, i.é, o uso da língua faria remotamente o controle do aparecimento de conceitos no cérebro do ouvinte.

No CLG, o signo foi apresentado graficamente como na figura ao lado. As setas laterais, para cima e para baixo, que se vê na figura, parecem representar a seta horizontal que fora apresentada antes $(c \rightarrow i) \mathrm{e}$ $(i \rightarrow c)$. 0 fato de atuarem conjuntamente nessa nova representação do signo se justificaria pela afirmação: "Esses dois termos estão

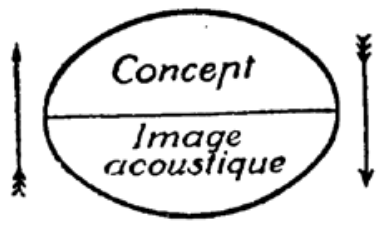
intimamentos unidos e um reclama o outro". ${ }^{207}$ Nesse contexto, a proposição de que processos executivos e processos receptivos (estes, o objeto principal da análise linguística, 
conforme o CLG) seriam diferentes não coere com a proposição de signo ora apresentada. Lembrando que o processo executivo relacionava-se diretamente com a fala e o receptivo, com a língua. Ainda no CLG, afirmava-se que o propósito era a "Linguística da Língua" e que se evitaria, maximamente, confundir os "limites que separariam os dois domínios".208

Do que vimos, o signo linguístico de duas faces, redenominadas "significante e significado" para o que era "conceito" e "imagem acústica", respectivamente, era orientado no sentido do significante para o significado. Uma representação possível para a proposição de signo, que diferenciaria o processo executivo do receptivo, seria $(i /$ arvuri/ $\rightarrow c)$, para o executivo, e ( $c \rightarrow i /$ arvori/) para o receptivo, ou pela terminologia final ( $\mathrm{S} \underline{\mathrm{te}}_{\text {(arvuri) }} \rightarrow \mathrm{S} \underline{\mathrm{do}}_{\text {("árvore") }}$ ).

Quando Peirce estabeleceu que o representamem exigia um interpretante para caracterizar-se como tal, destacadas as diferenças na relação entre representamem e significante, era exatamente o mesmo vínculo obrigatório que se estabelecia entre o representamem e o interpretante, i.é, para a existência de um símbolo qualquer, um representamem precisaria apontar para um interpretante, da mesma maneira que um significante precisaria apontar para um significado.

Embora nenhum Representamem realmente funcione como tal até realmente determinar um Interpretante, torna-se um Representamem tão logo seja plenamente capaz de assim proceder; e 


\section{Formação simbólica}

sua Qualidade Representativa não depende necessariamente de ele alguma vez realmente determinar um Interpretante, nem de ele alguma vez ter realmente um Objeto. ${ }^{209}$

A contribuição do CLG para a teoria dos símbolos, de maneira geral, é precisamente a que extrai do representamem uma unidade psíquica devidamente formalizada. De alguma maneira ainda mal definida, essa ideia já vinha expressa em Humboldt quando afirmara que a vibração material do som poderia ser esquecida, como já vimos. No CLG, havia uma restrição, ao se caracterizar o que foi lá descrito como "signo linguístico". Este se comporia, segundo o CLG, somente de uma parcela das características simbólicas tal como foram descritas. A língua era tratada como um fato social durkheimiano, pré-existente ao indivíduo, descartando-se dessa maneira tudo o que não fosse psíquico. 0 signo linguístico, portanto, ia especialmente reduzido a (i $\leftrightarrows \mathrm{c}$ ). Como nosso objetivo aqui é o cotejo entre teorias do símbolo, e o signo linguístico entra nesse contexto, entendemos que signo linguístico proposto no CLG seria apenas uma análise incompleta destinada a um objeto teórico específico, cuja materialidade foi descartada apenas para fins explicativos.

Um pouco mais adiante, John Broadus Watson (1878-1958) teria uma interpretação desse fenômeno, na formação do quadro teórico behaviorista.

0 estímulo visual simples de uma luz vermelha não provoca que se retire a mão. Nem mesmo a 
luz vermelha causa qualquer reação. [...] Mas, se coloco a luz vermelha e imediatamente a seguir, estimulo a mão do sujeito com uma corrente elétrica e repito esse procedimento um número de vezes suficiente, a luz vermelha provocará, involuntariamente, a retirada da mão. A luz vermelha converte-se agora em um estímulo substituto: provocará $\mathrm{R}$ quantas vezes se estimule o sujeito desta forma. Alguma coisa aconteceu para que se produzisse essa mudança que - conforme já se disse - chama-se condicionamento - a reação permanece a mesma, mas aumentamos o número de estímulos suscetíveis de despertá-la. Com o propósito de expressar esse novo estado de coisas, descrevemos essa mudança falando de estímulo condicionado. ${ }^{210}$

No entanto, apesar de sua explicação ser bastante convincente, sobretudo à luz das descobertas de Pavlov à época, parece que o autor ou confundiu algum E com $\mathrm{R}$, ou eliminou uma $\mathrm{R}$ intermediária, tomando corpo e sensação como o mesmo fenômeno. O psicólogo Wolfgang Köhler (1887-1967), ao criticar a proposta behaviorista de Watson, afirmou que a fórmula psicológica correta deveria ser: padrão de estimulação $\rightarrow$ organização $\rightarrow$ resposta aos produtos da organização. ${ }^{211}$

Definindo $\mathrm{E}_{1}$ como (choque - incondicionado), $\mathrm{E}_{2}$ como (luz vermelha) e $\mathrm{R}_{1}$ (retirada da mão condicionado), o autor propõe que se $\mathrm{E}_{1} \rightarrow \mathrm{R}_{1}$, quando ocorre seguidamente $E_{2}+E_{1} \rightarrow R_{1}$, então $E_{2} \rightarrow R_{1}$. No entanto, quando ocorre $E_{2}+E_{1} \rightarrow R_{1}$ parece que $\mathrm{E}_{2} \rightarrow\left(\mathrm{E}_{1} \rightarrow \mathrm{R}_{1}\right) .{ }^{212}$ Nesse caso, $\mathrm{E}_{2}$ não dispararia $\mathrm{R}_{1}$, 


\section{Formação simbólica}

mas sim a lembrança de que $\mathrm{E}_{1}$ viria a seguir. Essa reinterpretação justificaria o caso do descondicionamento. Se ocorrer seguidamente $\mathrm{E}_{2} \rightarrow \sim \mathrm{E}_{1}$, isto é, $\mathrm{R}_{1}$ poderia não ocorrer, não haveria razão para $E_{2} \rightarrow\left(E_{1} \rightarrow R_{1}\right)$, ou seja, $E_{2} \rightarrow\left(E_{1} \rightarrow R_{1}\right)$ seria falso. Se o estímulo condicionado puder ser falso ou verdadeiro, então ele seria simbólico, seria somente um discurso sobre o mundo e não o mundo. ${ }^{213}$

Também poderíamos imaginar que $\mathrm{E}_{1} \rightarrow \mathrm{R}_{1}$ seria um equívoco, na medida em que parece que haveria um intermediário somático aí: $\mathrm{E}_{1} \rightarrow \mathrm{R}_{d o r}$ e $\mathrm{R}_{d o r} \rightarrow \mathrm{R}_{1}$. Essa reinterpretação de $\mathrm{E}_{1} \rightarrow \mathrm{R}_{1}$, com um intermediário somático, a dor local, poderia justificar melhor a proposição de $\mathrm{E}_{2} \rightarrow \mathrm{R}_{1}$ do autor, uma vez que $\mathrm{E}_{1}$ não estaria presente, quando $\mathrm{E}_{2} \rightarrow$ $\mathrm{R}_{1}$ ocorre. Então, se $\mathrm{E}_{1} \rightarrow \mathrm{R}_{d o r}$, e $\mathrm{E}_{2}+\mathrm{E}_{1} \rightarrow \mathrm{R}_{d o r}$ e $\mathrm{R}_{d o r}$ $\rightarrow \mathrm{R}_{1}$, então $\mathrm{E}_{2} \rightarrow\left(\mathrm{E}_{1} \rightarrow \mathrm{R}_{\text {dor }}\right) \rightarrow \mathrm{R}_{1}$. Também, nesse caso, se ocorrer $\mathrm{E}_{1} \rightarrow \sim \mathrm{R}_{\text {dor }}$ a sequência $\mathrm{E}_{2} \rightarrow\left(\mathrm{E}_{1} \rightarrow \mathrm{R}_{\text {dor }}\right)$ seria Falsa. Logo, $\mathrm{E}_{2} \rightarrow\left(\mathrm{E}_{1} \rightarrow \mathrm{R}_{\text {dor }}\right)$ seria simbólica, pois $\left(\mathrm{E}_{1} \rightarrow \mathrm{R}_{\text {dor }}\right.$ ) seria somente um interpretante peirciano. Novamente, a relação entre $\mathrm{E}_{2} \rightarrow\left(\mathrm{E}_{1} \rightarrow \mathrm{R}_{\text {dor }}\right)$ será simbólica, fazendo parte do discurso sobre o mundo.

Um exemplo interessante que se poderia pensar é o caso da reação de um sujeito adulto qualquer, ao dar uma topada com o pé descalço num pé de mesa. Poderíamos imaginar alguma coisa como Etopada $\rightarrow$ $R_{\text {dor }} \rightarrow$ Rgrito ; se o sujeito estiver sozinho, é possível que Rgrito não ocorra; mas, se estiver acompanhado, possivelmente Rgrito ocorrerá. Temos, pois, 
$\mathrm{e}$

$$
\text { Etopada } \rightarrow \mathrm{R}_{\text {dor }} \rightarrow \sim \mathrm{R}_{\text {grito }}
$$

$$
\text { Etopada } \rightarrow \text { Rdor } \rightarrow \text { Rgrito }
$$

0 que nos leva à condição de $\mathrm{R}_{\text {dor }} \rightarrow \mathrm{R}_{\text {grito }}$ ser simbólica. Desse ponto de vista, o simbolismo independe do fato de o representamem ser igual ao objeto (ícone) ou ser naturalmente decorrente do objeto (índex), mas sim do fato de poder ser falseado, isto é, manipulado. Ainda que Watson (1925) não tivesse externado o mesmo raciocínio, ele parece estar presente no trecho que vai abaixo.

Precocemente, o ser humano tem um substituto verbal dentro de si mesmo para cada objeto no mundo. Assim, ele leva, junto de si mesmo, o mundo ao seu redor por meio dessa organização. Ele pode manipular a palavra mundo na privacidade do seu quarto ou quando ele se deita em sua cama no escuro. Muitas das nossas descobertas vêm por meio dessa capacidade de manipular um mundo de objetos não realmente presentes para os nossos sentidos. [...] Nós carregamos este mundo em torno de nós como organização corporal real, na organização muscular e glandular da nossa garganta, peito, etc. (incluindo, naturalmente, os órgãos dos sentidos nos músculos e do sistema nervoso). Essa organização está pronta para funcionar dia e noite, sempre que o estímulo apropriado é dado. 0 que é este estímulo apropriado? ${ }^{214}$

Ao propor a hipótese da existência de um substituto verbal, Watson (1925) tratou especificamente da diferença entre o que chamamos de intermediário somático e a sensação cognitiva propriamente dita. Tal separação, segundo ele mesmo, seria o que nos 


\section{Formação simbólica}

permitiria manipular um mundo de objetos não presentes aos nossos sentidos.

Vale lembrar que, em meados do século XX, Burrhus Frederic Skinner (1904-1990) questionou essa abordagem de Watson, entendendo que "somente quando os conceitos de estímulo e resposta são usados de forma muito vaga pode o princípio do condicionamento servir como um protótipo biológico de simbolização". ${ }^{215}$ No entanto, retomou essa mesma distinção entre a reação de um reflexo condicionado e o impulso decorrente dela, chamando a este último como "operador discriminado".

Quando a cozinheira anuncia "- Jantar!", o ouvinte pode responder de duas maneiras: (i) salivando, ou respondendo de alguma outra forma com os músculos lisos ou as glândulas, ele demonstra o condicionamento pavloviano; (ii) dirigindo-se à mesa e sentando-se, ele demonstra um operante discriminado reforçado em ocasiões passadas semelhantes. ${ }^{216}$

Muito embora a posição de Skinner já tenha sido largamente questionada, 217 é interessante notar que, nesse caso, a inadequação da proposta vai exatamente na mesma direção da que fora Watson. 0 impulso decorrente de um reflexo condicionado, tomado aí como "operador discriminado", exige uma série de percepções e de padrões comportamentais selecionados pelo sujeito a partir de seu próprio conhecimento acumulado que não se manifestam de forma visível, que vão desde a compreensão da língua falada, da localização dos alvos dos movimentos até as regras de conduta social que 
devem ser mantidas durante o procedimento de sentar-se à mesa e não simplesmente avançar sobre os alimentos. Trata-se, pois, da mesma supressão de respostas intermediárias, inúmeras e variadas, que procuramos acima demonstrar. De fato, o estímulo que desencadeia o comportamento final dos sujeitos bem como esse comportamento teriam de ser expressos na forma de uma equação extremamente complexa que poderíamos resumir como $\mathrm{E}_{\left[3 \tilde{a}^{\mathrm{D}} \text { tár] }\right.} \rightarrow$ $($...?) $\rightarrow$ Rir para a mesa e sentar-se.

Pode-se entender que o impulso motor de Pavlov, ou o operador discriminado, são comportamentos voluntários que ocorrem a posteriori, como resultados proprioceptivos das reações corporais decorrentes de reflexo condicionado. 0 sujeito percebe suas próprias reações e, então, toma as atitudes que elas requerem. Da mesma maneira que vimos para o processo receptivo $(i \rightarrow c)$ no uso da língua, a manipulação do estímulo desse reflexo condicionado permite-nos controlar remotamente as reações fisiológicas, no caso a salivação, tomadas por Pavlov como o substractum do pensamento.

0 estímulo parcial capaz de desencadear comportamentos e imagens permite-nos tomar a percepção humana como um processo indicial e não necessariamente feito por varredura. Assim, além da sequencialidade própria desse processo de condicionamento, também se percebe a capacidade de recomposição integral a partir de estímulos mínimos. 


\section{Formação simbólica}

A percepção indicial permite que estímulos parciais - ou representamina - possam ser rápida e sequencialmente utilizados na formação de interpretantes diversos. A composição de uma cena imaginária, portanto, pode ser feita a partir de um conjunto de estímulos previamente condicionados e sucessivos. De fato, é o que ocorre na fala. 0 trabalho de Jean Matter Mandler (1984) mostrou que a organização dos estímulos perceptivos é fundamental para a memorização e para o processamento, o que, de certa forma, corrobora a ideia de recomposição integral imaginária de uma cena a partir de estímulos mínimos oferecidos pela linguagem. Mandler apresenta, ainda, dois conjuntos de figuras, cujos elementos dispõem-se diferentemente. $\mathrm{Na}$ primeira figura, os elementos estão dispostos segundo uma organização visualmente aproximada do que seria a cena representada cotidianamente. Na segunda figura, os elementos não estão dispostos de maneira que possam representar uma cena cotidiana, mas, ao contrário, parecem espalhados aleatoriamente. ${ }^{218}$ A percepção da primeira figura é feita de forma mais acurada. 0 autor faz o mesmo com conjuntos de frases curtas organizadas de forma que permitem estabelecer uma relação de causalidade temporal em comparação com os mesmos conjuntos de frases curtas, mas, dessa feita, organizadas segundo a semelhança verbal entre elas. As sequências de frases que permitem estabelecer causalidade temporal foram melhor aproveitadas mnemonicamente do que as organizadas por semelhança verbal. A sucessão de 
indícios organizados de acordo com uma "sintaxe" coerente com a cotidiana parece, pois, favorecer grandemente a recomposição integral do interpretante peirciano.

Fazendo um pequeno intervalo em nossas considerações sobre o signo, no século $\mathrm{XX}$, com o as atividades de telecomunicação, desenvolvem-se nos Estados Unidos as pesquisas sobre comunicação; mas do ponto de vista da engenharia da comunicação. Claude Elwood Shannon (1916-2001) propõe, em 1948, para essa área a aplicação de modelos matemáticos, num artigo que se tornaria clássico: "Teoria Matemática da Comunicação". Sua preocupação era especialmente contabilizar a transmissão de informações que era feita por meio de sinais elétricos, eletromagnéticos ou eletrônicos codificados. Essa transmissão, segundo ele, ocorreria a partir de uma mensagem selecionada pela fonte de informações (information source) e codificada em algum tipo de sinal (signal) por um transmissor (transmitter). A esse sinal transmitido por meio de um canal (channel) qualquer ajuntar-se-iam informações indesejadas, chamadas de ruído (noise). A esse conjunto formado pelo sinal codificado e o ruído agregado ao canal, Shannon deu o nome de sinal recebido (received signal). Este seria capturado por um receptor (receiver) que, além de decodificar o sinal, o separaria do ruído, e o enviaria a um destino (destination). Então, a mensagem decorreria da decodificação desse conjunto formado pelo receptor e pelo destino. 


\section{Formação simbólica}

Warren Weaver (1894-1978) descreve o receptor como "uma espécie de transmissor em reverso, transformando novamente o sinal transmitido em mensagem e enviando a mensagem ao seu destino. Quando falo com você, meu cérebro é a fonte de informação e o seu é o destino". ${ }^{219}$ Se relembrarmos a definição de Peirce para o representamem, como efeito mental ou pensamento, podemos compará-la com esse Sistema Geral de Comunicação de Shannon (1948) e verificar que o signo peirciano teve uma redistribuição de seus elementos, mas perdeu a noção do objeto, deixando-o sem referência.

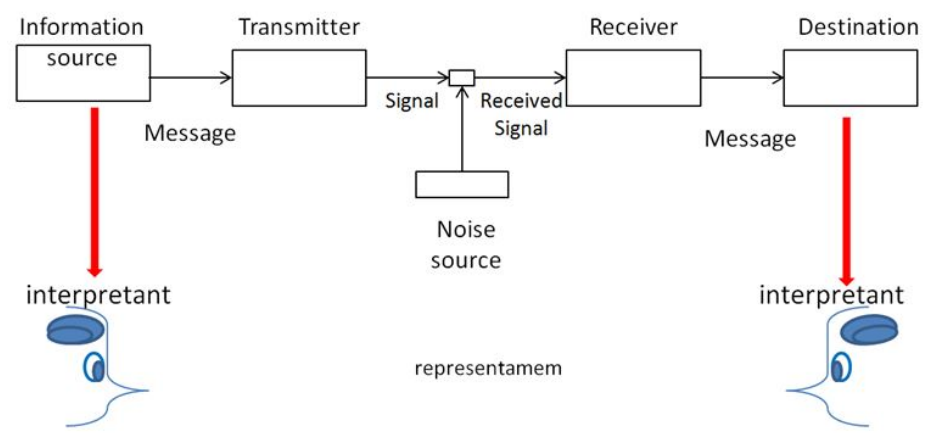

Em discurso realizado em 1956 na Linguistic Society of America, Roman Osipovich Jakobson (1896-1982) retomou a proposta do Sistema Geral da Comunicação de Shannon (1948), adaptando-a às necessidades dos estudos linguísticos. Com rara habilidade, Jakobson (1980) inseriu em seu diagrama a maior parte dos elementos formadores dos signos. Os elementos corpóreos de Sexto Empírico foram retomados como contato e contexto, 
estabelecendo, respectivamente, as funções referencial e fática. 0 sentido de Frege foi retomado como mensagem, estabelecendo a função poética. 0 interpretante de Peirce reaparece, agora separado como remetente e destinatário, estabelecendo as funções emotiva e conativa, respectivamente. No caso do interpretante de Peirce, Jakobson, aparentemente, priorizou totalmente seu aspecto de pensamento e efeito mental, assumindo que tais não poderiam ser senão parte dos participantes da comunicação. De certa maneira, Jakobson reparte a noção que vai proposta em Sexto Empírico que diz respeito à codificação que "os bárbaros não entendem". Assim, como um elemento separado, o signo linguístico do CLG - explícito no sistema geral da comunicação como as partes que se referiam à codificação e à decodificação do sinal, isto é, o transmissor e o receptor - iria como código, que, por sua vez, estabeleceria a função metalinguística. Nesse modelo de Jakobson, o signo assumiria um papel muito mais envolvente, gerando a própria comunicação. 0 signo deixaria de ser um construto teórico independente e se estabeleceria como um fenômeno que poderia inserir-se no conjunto das atividades comunicativas. 


\section{Formação simbólica}

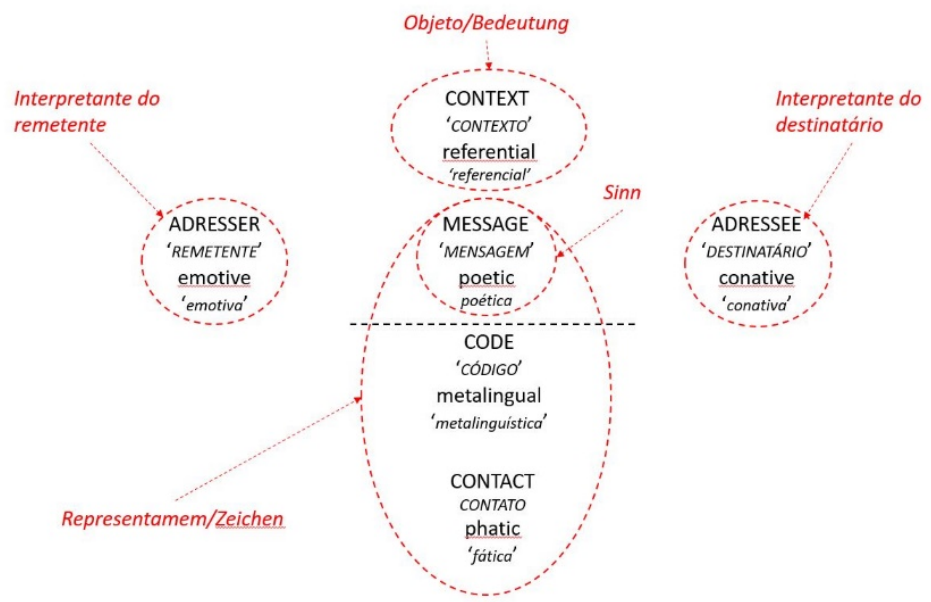

Sinn

A manipulação de símbolos dessa natureza, como afirmou Frege, é fundamental para a criação da arte, da ficção. No entanto, para mais do que isso, esse tipo de símbolo pode aparecer num sem-fim de expressões que praticamente obrigam os receptores a criar referências fregianas, que, na realidade, são apenas a superposição dos valores do representamem e do objeto percianos. Com isso, não somente nos equivocamos na percepção da realidade reagindo emocionalmente a estímulos inexistentes, mas também somos levados a crer na existência dos fenômenos mais impossíveis e incoerentes. 
Waldemar Ferreira Netto 


\section{Narrativas}

Conforme vimos no primeiro capítulo, quando discutimos as sociedades pela hipótese de Durkheim, as sociedades tradicionais podem se caracterizar pela predominância de status sociais atribuídos e, consequentemente, pela maior sensação de coletividade, em que o indivíduo se confundiria com o grupo. Desse ponto de vista, qualquer indivíduo seria prototípico desses status socialmente atribuído: qualquer criança serviria de exemplo para essa categoria, assim como qualquer homem, qualquer intersexual, qualquer pai, qualquer mãe, todos teriam o desempenho de seus papéis realizados de acordo com as expectativas da própria sociedade. Numa sociedade moderna, vimos que a predominância cada vez maior de status adquiridos promoveria uma diversificação também crescente de comportamentos individuais e, consequentemente, uma sensação cada vez menor de coletividade. Nesse caso, pelo aumento progressivo de status sociais disponíveis, uma forma prototípica das categorias definidas pelos status atribuídos seria cada vez mais rara. Dificilmente seria possível encontrar um homem prototípico, uma mãe prototípica, um brasileiro prototípico... Os indivíduos passariam, nas sociedades modernas, a ter de investir cada vez mais na aquisição de seus status e no desempenho de seus papéis correspondentes. 
No segundo capítulo, discutimos a hipótese de que esses status/papéis se configurariam culturalmente na forma de crenças que serviriam de base para as avaliações próprias do senso comum. A observação da realidade por meio das aberturas periscópicas do submarino de Gellner levaria a generalizações precipitadas, características do senso comum, sujeitas a todo tipo de viés diretamente relacionado com as propensões momentâneas da sociedade. 0 senso comum criaria uma ilusão de realidade que nos faria tomar nossas próprias crenças como a realidade que está lá, fazendo parte da natureza das coisas e, então, retomando Mário de Andrade, a realidade nos apareceria distorcida por conta de "preconceitos, indisposições, antipatias, ignorâncias, hereditariedade, circunstâncias de tempo, de lugar", dentre outras coisas.

As hipóteses sobre a formação do indivíduo foram discutidas no terceiro capítulo. Vimos que, de maneira semelhante à proposta de Ralph Linton, a identidade pessoal também pode ser tomada como um dos papéis sociais que desempenhamos na sociedade. Desse ponto de vista, a elaboração da identidade poderia ser vista como a construção de uma narrativa autobiográfica em que podemos tratar a nós mesmos tanto como narradores de primeira ou de terceira pessoas, assumindo-nos a nós mesmos como personagens de uma narrativa que se desenvolve em tempo real. Assim, a linguagem pôde ser tratada como estratégia principal desse processo. 


\section{Narrativas}

A interpretação da linguagem como um conjunto organizado de símbolos foi objeto do quarto capítulo. Vimos que a formação de símbolos poderia ser tomada como um processo que se desencadeasse à revelia de seu portador. Nesse caso, a sequência multidirecional de causalidades decorrentes das diversas percepções, tal como interpretamos em Hume, estaria diretamente associada com o desenvolvimento dos interpretantes de Peirce, que se desencadeariam a partir de representamina devidamente reconhecidos como tais.

Nossa preocupação neste capítulo será justamente a de tentar entender como a linguagem usada em narrativas pode ser efetivamente analisada de maneira a corroborar com todas as hipóteses anteriores. O termo "narrativa" se reporta a um conjunto muito grande de manifestações linguísticas. Geralmente está associado a um texto previamente elaborado que é reproduzido numa enunciação. Ele também se associa a uma produção linguística improvisada durante a própria enunciação. Nesse caso, geralmente podemos imaginar que o improviso possa ser somente da mensagem, ou Sinn - quando já temos todas as referências, ou Bedeutung, memorizados, independentemente de termos sido testemunhas ou não - ou, então, o improviso é completo, em que referências e mensagens vão sendo construídas conforme se desenvolve a própria enunciação. Nos dois casos, podemos ter, de fato, referências fictícias e, então, narrativas de ficção. Seriam, portanto, mentiras. 
José de Souza Martins propôs que a mentira pudesse ser "uma forma de conhecimento crítico da situação social imediata e das relações sociais vivenciadas por quem dela se vale para evitar que a verdade macule quem mente ou quem o uso da mentira pretende resguardar". ${ }^{220}$ Desse ponto de vista, podemos tomar a própria narrativa de ficção como uma reação que o "conhecimento crítico da situação social imediata" desencadeia durante a enunciação. Martins (2014) ainda considera que

Estamos em face do desencontro entre o que a pessoa é e o que a sociedade diz que ela precisa ser. 0 mentiroso mente porque sua concepção das relações sociais é por ele mesmo admitida como frágil, imprópria. Mente para obter vantagens que a insuficiência do seu equipamento cultural de identificação não lhe permitiria obter se não mentisse. Ao mentir, ele reconhece a precedência e a superioridade da concepção do que as coisas deveriam ser, que imputa ao outro, àquele a quem a mentira é dirigida. 221

Desse ponto de vista, qualquer narrativa de ficção pode ser tomada como essa reação tanto ao desencontro entre o desempenho socialmente esperado dos papéis sociais, como à insuficiência do equipamento cultural disponível para o autor da narrativa. Se é somente a figura do narrador que está disponível num texto narrativo, pois o autor será somente um interpretante peirciano gerado pela disposição das palavras usadas para a sua constituição, temos que a mentira tem de ser 


\section{Narrativas}

experienciada tanto pelo interlocutor como pelo próprio locutor do discurso.

Nem sempre é fácil fazer a distinção entre uma narrativa de ficção e uma mentira. Poderíamos simplificar essa questão dizendo que narrativas de ficção são mentiras sofisticadíssimas. Essa definição, entretanto, desconsidera que as mentiras têm de ser tomadas principalmente em seu momento específico de enunciação, isto é, são narrativas de ficção que ocorrem em tempo real e com alinhamento entre autor, locutor e narrador. Assim, essa questão também teria de ser tratada discursivamente.

A opção de tratar uma narrativa como factual ou ficcional, nesse caso, decorreria especialmente da habilidade do interlocutor de fazer comparações de enunciados como vimos nas propostas de Popper (1974). Esse tipo de comparação será imprescindível apenas para alguns discursos, tais como o histórico, o jurídico e o científico. No caso particular das narrativas de entretenimento ou de exemplo, essa comparação será totalmente desnecessária.

A narrativa factual, de maneira específica, seria um subconjunto das narrativas em geral. Por ser necessária uma série de procedimentos para a sua inserção nesse conjunto de discursos narrativos e, como é o caso do discurso científico, longamente discutido por Popper (1974), a narrativa factual seria mais propriamente uma hipótese corroborada pelos argumentos científicos adequados. Como já 
dissemos, essa corroboração é desnecessária e não precisamos fazer a distinção entre fato e ficção, entre mentira e realidade.

Apesar de óbvio, antes de tentar analisar uma narrativa qualquer, temos de ler a narrativa. A leitura, entretanto, deve ser feita como mero entretenimento, apenas deixando que se criem todos os interpretantes e que se forme uma sequência de imagens semelhantes àquelas que temos quando assistimos a um filme mais envolvente. Essa leitura acrítica permite-nos perceber quais eram as intenções finais do autor, qualquer que este tenha sido, que, em conjunto com o locutor, persistem no texto que temos à mão, ou aos olhos, ou aos ouvidos. É especialmente essa leitura que nos possibilita simular nossa experiência como heróis dos eventos narrados e termos as mesmas emoções, mais intensas ou menos intensas, que foram propostas nos textos que nosso equipamento cultural de identificação não nos permitiria ter. Para tanto, seremos obrigados a assumir a postura que o narrador, agora tomado como autor, espera que tenhamos. Essa postura esperada é a que foi proposta por Umberto Eco (1932-2016) como a de leitor-modelo. 0 conceito proposto por Eco (2004) era:

Para "decodificar" uma mensagem verbal é preciso ter, além da competência linguística, uma competência variadamente circunstancial, uma capacidade passível de desencadear pressuposições, de reprimir idiossincrasias, etc. etc. ${ }^{222}$ 


\section{Narrativas}

0 autor do texto, por sua vez, precisaria da sensibilidade de saber de antemão qual é a competência de seu futuro leitor, ou de seu atual ouvinte. A homogeneidade das sociedades tradicionais possibilitaria que as narrativas tivessem um alcance total dentro da sociedade que a produziu. Numa sociedade moderna, a situação seria diferente, pois o autor teria de prever as características de seu leitor.

Para organizar a própria estratégia textual, o autor deve referir-se a uma série de competências (expressão mais vasta do que "conhecimento de códigos") que confiram conteúdo às expressões que ele usa. Ele deve aceitar que o conjunto de competências a que se refere é o mesmo a que se refere o próprio leitor. Por conseguinte, preverá um Leitor-Modelo capaz de cooperar para a atualização textual como ele, o autor, pensava, e de movimentar-se interpretativamente conforme ele se movimentar gerativamente. 223

Eco (2004?) propôs que o autor tenha um tipo previsto de interlocutor. Desse ponto de vista, seria mais do que o conhecimento do código linguístico (ou outro código), mas, especialmente, do compartilhamento do senso comum, como o vimos anteriormente. Essa proposta de leitor-modelo de Eco coaduna-se com a de Bourdieu (1996) quando este afirmou que

[...] o produto linguístico só se realiza completamente como mensagem 224 se for tratado como tal, isto é, decifrado; além do fato de que os esquemas de interpretação que os 
receptores põem em ação em sua apropriação criativa do produto podem ser mais ou menos distanciados daqueles que orientaram a produção. 225

A ideia de Bourdieu quanto a um receptor que coloca em ação seus esquemas de interpretação é muito próxima daquela de leitor-modelo de Eco. Em ambas as hipóteses, os autores atribuem ao interlocutor a responsabilidade de consumar a comunicação efetivamente. Bourdieu vai mais além:

[...] cada receptor contribui para produzir a mensagem que ele recebe e aprecia, importando para ela tudo o que constitui sua experiência singular e coletiva. Pode-se estender tudo o que dissemos sobre o discurso poético apenas porque ele conduz à máxima intensidade quando se sai bem - o efeito que consiste em despertar experiências variáveis segundo os indivíduos. [...] 0 paradoxo da comunicação é que ela supõe um meio comum, mas que só tem êxito ao suscitar experiências singulares, isto é, socialmente marcadas; isso é evidente no caso limite em que se trata de transmitir emoções, como muitas vezes se dá na poesia. ${ }^{226}$

Há uma questão terminológica insolúvel no âmbito dos estudos da linguagem que precisamos salientar. O que Bourdieu, no trecho citado acima, chama de "esquemas de interpretação" é o que entendemos, conforme discutimos no capítulo anterior, como o interpretante de Peirce. Essa aproximação que fazemos permite-nos entender as expressões "despertar experiências", "apropriação criativa do produto", "produzir a mensagem que ele recebe e 


\section{Narrativas}

aprecia" e ainda "suscitar experiências singulares" como a formação de interpretantes. Podemos, ainda, retomar a noção de sistemas de "diferentes percepções ou diferentes existências encadeadas pela relação de causa e efeito que produzem, destroem, influenciam e modificam-se umas às outras" que Hume procurou desenvolver no século XVIII, para inseri-la na discussão atual, na medida em que aceitemos a hipótese de que também se assemelha aos interpretantes peircianos como um sistema desse tipo, mas eminentemente simbólico. Os representamina linguísticos é que desencadeariam esse sistema de diferentes percepções proposto por Hume. Não se trata de um conjunto de alucinações ou de imagens oníricas, mas, ainda que possam manifestar-se de forma semelhante no indivíduo que as produz, tem origem controlada pelo discurso a que ele se permite submeter. Assumir o posto de leitor-modelo é, portanto, semelhante ao que Bourdieu propôs quando definiu a "dominação simbólica".

Toda dominação simbólica supõe, por parte daqueles que sofrem seu impacto, uma forma de cumplicidade que não é submissão passiva a uma coerção externa nem livre adesão de valores. ${ }^{227}$

O objetivo de Bourdieu era o de descortinar uma forma de dominação social que não se manifestaria coercitivamente pelo poder da violência ou da legalidade, mas especialmente por aquele dos fatos sociais que imprimem diferenças desequilibradoras entre indivíduos de uma mesma sociedade ou 
mesmo entre sociedades. Embora estejamos partindo de princípio semelhante, ao aplicar a noção de dominação simbólica às narrativas, entendemos que as consequências desse tipo de dominação não precisam ter o mesmo caráter desequilibrador.

Ao assumir o papel de leitor-modelo, o receptor é levado a assumir todo o conjunto de crenças que o autor propõe, consciente ou inconscientemente, para sua narrativa. Alguns pesquisadores propuseram modelos de como esse tipo de coerção atuaria.

Robert King Merton (1910-2003), procurando entender como um rumor corriqueiro a respeito das condições financeiras de um estabelecimento bancário foi capaz de levar esse estabelecimento à bancarrota, propôs a noção de "profecia autorrealizável". ${ }^{228}$ Esse tipo de profecia autorrealizável decorreria de uma narrativa inverídica que desencadearia um comportamento nos receptores, que a tomariam como verdadeira, capaz de causar o próprio fato profetizado, o que a tornaria verdadeira. No exemplo do autor, o banco faliu exatamente porque o rumor era de que faliria e, então, seus correntistas retiraram o dinheiro de suas contas e de suas aplicações naquele banco, provocando, assim, sua falência.

Podemos aplicar essa mesma hipótese à teoria dos status e papéis de Linton que, então, atuaria exatamente nesse sentido. A eficácia desse procedimento narrativo parece ser sempre muito grande, 


\section{Narrativas}

falhando apenas quando o que se pretende é mudar o senso comum. Assim, se uma pessoa nascer com órgãos genitais masculinos, então a narrativa que se fizer sobre ela vai atribuir-lhe o status de gênero masculino; se ela nascer com órgão genitais femininos, então a narrativa que se fizer sobre ela atribuir-lhe o status de gênero feminino. Essa atribuição de status de gênero é eficaz se quem o recebe estiver de acordo com o senso comum. No entanto, perde sua eficácia por vários motivos, ou porque se trata de intersexualidade, ou porque não se deseja ter o gênero que o senso comum quer lhe atribuir. Se as narrativas que se fizerem sobre ele tratarem-no de acordo com o gênero escolhido, isso será bem-sucedido, ainda que conflituoso, a despeito do gênero que o senso comum tende a lhe atribuir. Note-se que, da mesma maneira que a condição financeira do estabelecimento bancário do exemplo de Merton era insignificante para que a profecia autorrealizável se cumprisse, a configuração do órgão genital do indivíduo, para sua caracterização no status de gênero, também não seria significativa. Em ambos os casos seria a eficácia da narrativa que estabeleceria os comportamentos em geral.

Leon Festinger (1919-1989), nos anos cinquenta do século XX, propôs uma teoria chamada Dissonância Cognitiva, cuja hipótese fundamental era a de que "a realidade que incide sobre uma pessoa exercerá pressões na direção do estabelecimento de 
correspondência entre os elementos cognitivos apropriados". 229

Nesse modelo, Festinger entendia a realidade como quaisquer fatos físicos, sociais ou psicológicos. 0 autor sumarizou esse conjunto sob o rótulo de "cognição", que definiu como as coisas que uma pessoa conhece sobre si mesma, sobre seu comportamento e sobre o meio que a cerca. ${ }^{230}$ Esse rótulo abrangeria inclusive o conjunto de crenças, valores, atitudes de um indivíduo. ${ }^{231}$

Por outras palavras, os elementos de cognição correspondem, em sua maior parte, ao que a pessoa faz ou sente, ou ao que existe realmente no meio ambiente. No caso de opiniões, crenças e valores, a realidade pode ser o que os outros pensam ou fazem; em outras circunstâncias, a realidade pode ser o que é conhecido experiencialmente pela pessoa ou o que outros lhe disseram. ${ }^{232}$

De maneira geral, até mesmo como uma redução grosseira da teoria, o modelo proposto envolveria especialmente o sistema de diferentes percepções encadeadas pela relação de causa e efeito de Hume. Na proposta de Hume, a formação do self decorreria da relação entre percepção e memória. No modelo de Festinger, tudo foi englobado sob o mesmo rótulo de "elementos da cognição", ou simplesmente "cognição". A dissonância cognitiva seria a ocorrência simultânea de elementos cognitivos incompatíveis entre si. Festinger entendia que essa dissonância seria, por si só, uma motivação pessoal 


\section{Narrativas}

suficiente para o indivíduo envidar esforços para resolvê-la.

Quando um indivíduo assume seu papel como leitor-modelo durante a enunciação de uma narrativa, ele permite que um conjunto de crenças seja acrescentada ao seu, por conta da nova personalidade que ele assume, ad hoc. Nesse caso, tanto a teoria das profecias autorrealizáveis de Merton, como a teoria da dissonância cognitiva de Festinger podem ser aplicadas. O leitor-modelo procuraria, pelo menos temporariamente, perfilar-se com as crenças a que vai sendo submetido no decorrer da narrativa. Como não se trata de substituição, mas de acréscimo, cuja duração deveria ser igual à da enunciação da narrativa, a nova personalidade assumida se esvairia com o próprio texto. No caso de se manifestarem dissonâncias cognitiva sérias, em que o herói fosse racista, por exemplo, o indivíduo poderia abandonar seu papel de leitor-modelo, tomando o turno do locutor, se a narrativa estiver ocorrendo num diálogo, ou desviar o olhar do texto, se for uma narrativa escrita, por exemplo.

O que dissemos, entretanto, só é verdadeiro quando sabemos que se trata de uma narrativa de ficção. No caso em que essa informação não esteja presente, ou não seja perceptível, tal como já salientou Bourdieu, nem sempre é possível abandonar o papel de leitor-modelo. Por exemplo, se numa escola uma criança for definida inadequadamente como portadora de défict de atenção, ela passará a ser 
sempre tratada como tal, inclusive por si mesma. Isso pode ser aplicado a quaisquer status atribuídos que uma sociedade possa desenvolver. Naomi Wolf mostrou como o critério de beleza feminina na sociedade ocidental foi criado discursivamente pelos mais diversos meios de comunicação na segunda metade do século XX. Segundo ela, o fato de um número significativo de meninas adolescentes assumirem esse papel provocou o que podemos considerar como uma epidemia de casos de anorexia e bulimia. Essas meninas provocavam, e talvez ainda ocorra, uma verdadeira automutilação, com o único propósito de enquadrarem-se no perfil de beleza que lhes foi proposto. ${ }^{233}$

Esse processo de atribuição de status nem sempre é negativo. Ao saber que seu nome provém de Jakairá, por exemplo, um indivíduo guarani será tratado como alguém que tem propensão para tornar-se pajé. Se ele se interessar por isso e assumir essa propensão como verdadeira, ele se sentirá fortemente motivado para empenhar-se no conhecimento necessário para assumir esse status.

A narrativa que vai no Texto 4, abaixo, tem seus eventos transcorrendo em área urbana. 0 autor pressupõe que o leitor domine, além do próprio código linguístico, uma série de crenças relativas a esse ambiente.

\section{Texto 4: Vindo da casa da pitanga (Lukas) $>$ sec hj \\ $>$ de boa vindo da casa da pitanga}




\section{Narrativas}

$>$ decido comprar um cachorro quente no meio do caminho

>venho comendo o cachorro quente no caminho $>$ feliz pra caralho comendo meu cachorro quente $>$ do nada aparece um mlk gigante gritando PERDEU PERDEU

$>$ tranquei o cu, não passava nem wifi

$>$ fudeu, este filho da puta vai levar meu dinheiro e celular

>pegou o resto do meu cachorro quente e guaraná e saiu comendo

$>$ to até agora sem entender q porra aconteceu cmg

>acho q vou registrar um b.o pra recuperar meu cachorro quente

No Texto 4, é fundamental sabermos que estamos sujeitos a ser assaltados na rua, que não devemos reagir ao assaltante, que o objeto do assalto são preferencialmente telefones, joias e dinheiro. Ora, esse não é o senso comum em sociedades que vivem nas selvas amazônicas, por exemplo, mas faz parte do senso comum de qualquer morador da cidade de São Paulo. É necessário que esse senso comum esteja disponível para que a finalização irônica da narrativa faça algum sentido. Faz parte do anedotário político brasileiro que um dos presidentes, por demais vaidoso, queria alugar um túmulo em Israel por apenas três dias. Trata-se de uma anedota cujo humor só será desencadeado nos interlocutores que conheçam a história cristã da ressurreição, para perceber a autoassociação da personagem com esse evento. Ainda que bastante divulgada, a narrativa bíblica faz parte do senso comum próprio dos seguidores dessa religião. Para que o interlocutor 
possa experienciar as emoções que estariam presentes no texto, seria, portanto, necessário aceitar o senso comum pressuposto ali. É comum também que a ausência desse compartilhamento estabeleça um texto que, apesar de reproduzido, não faça nenhum sentido para o interlocutor. É o caso da quadrinha cantada:

$$
\begin{aligned}
& \text { Eu sou pobre, pobre, pobre } \\
& \text { de marré, marré, marré } \\
& \text { eu sou pobre, pobre, pobre } \\
& \text { de marré deci. }
\end{aligned}
$$

Avelino Medina (2009) explica que a expressão "marré deci" parece ter tido origem no nome do bairro parisiense de Marais [ma' $y \varepsilon$ ] e "deci" da expressão "d'ici" [di'si]. Há uma versão francesa de 1898, que reproduzo:

\section{Je suis pauvre, je suis pauvre \\ Anne-Marie Jaqueline \\ Je suis pauvre dans ce jeu d'ici}

Ainda que não esteja entre nossas preocupações a origem dessa canção, o exemplo aponta para o fato de que a expressão "marré deci" fixou-se a despeito de ter um significado.

As narrativas são um caso notável das manifestações linguísticas. São facilmente reconhecidas em qualquer cultura. Não há como não as produzir. Fazem parte do cotidiano de qualquer pessoa. Talvez fosse necessário estabelecer diferen-ças entre as narrativas que se estudam e se discutem nas academias e as que não parecem ter o mesmo 


\section{Narrativas}

prestígio. Essa diferença, entretanto, apesar de nos estimular maximamente para promovê-la, não é o alvo deste momento.

Um dos que primeiro se dispôs a criar um método formal de análise de narrativa foi Vladimir Propp (1895-1970). Seu objeto eram as narrativas do que ele chamou de "conto maravilhoso". Sua intenção era encontrar variáveis e invariáveis nesses contos. Seu método estabeleceu que as narrativas teriam grandezas variáveis e grandezas constantes, ou invariáveis. Segundo ele, "o que muda são os nomes - e, com eles, os atributos - das personagens; o que não muda são suas ações, ou funções". ${ }^{234} \mathrm{Um}$ pouco mais adiante, o autor insistiu nesse ponto, afirmando que "o que importa é saber o que fazem as personagens. Quem faz algo e como isso é feito já são perguntas para um estudo complementar". 235

Propp chamou a atenção para o fato de que se deveria considerar que "a ação", e, portanto, a "função", não poderia ser definida fora de seu lugar no decorrer do relato. Segundo Propp, "a sequência dos acontecimentos tem suas leis, como também tem suas leis a narrativa literária. 0 roubo não pode ser efetuado antes de se arrombar a porta". ${ }^{236}$ Essa passagem nos permitiria atribuir a "sequência de funções" como um dos elementos que vão além das narrativas de contos maravilhosos. Para estes, ele propôs que a sequência de funções seria sempre idêntica. 
Curiosamente, Propp fez uma pequena ressalva: “É necessário mencionar que a lei citada refere-se somente ao folclore. Não são uma peculiaridade de gênero do conto maravilhoso como tal. Os contos criados artificialmente não se submetem a elas". ${ }^{237}$ 0 que diferenciaria um conto artificial e um conto natural (espontâneo?) não está claro na proposição de Propp. Possivelmente, o autor estaria se referindo a contos com autoria conhecida em contraste com contos sem autoria conhecida ou contos transmitidos oralmente. Pode-se entender que essa ressalva decorresse da proposta, que também aparecerá em Labov e Waletzky (1967) e Labov (1997), de que as narrativas orais teriam tendência a manter uma sequência temporal linear na apresentação de seus eventos.

Podemos pensar que, no modelo de análise proppiano das narrativas, destacam-se

a) grandezas variáveis;

b) grandezas invariáveis e

c) ordem sequencial das grandezas constantes.

A comparação das narrativas "Bóreas e o Sol", compilada por Esopo, e a narrativa taulipang "Onça e Chuva", compilada por Koch-Grünberg (1953), pode ser uma ilustração para essa análise proppiana.

A narrativa de Esopo, "Bóreas e o Sol", tem como personagens dois fenômenos meteorológicos personificados, que disputam entre si quanto a suas 


\section{Narrativas}

forças, tentando despir um homem. Bóreas, o vento, torna-se mais e mais intenso e tudo o que consegue é fazer o homem agarrar-se mais a suas roupas. 0 Sol, ao tornar-se mais intenso, faz o homem despir-se. A narrativa de Koch-Grünberg, "Onça e Chuva", tem como personagens um animal e um fenômeno meteorológico personificado, também disputando entre si quanto a suas forças, mas tentando fazer umas pessoas que haviam saído da maloca tornarem para dentro. A onça passeia pelas redondezas roncando forte para assustar as pessoas, e tudo o que consegue é fazer os homens decidirem flechá-la quando pudessem, sem demonstrar medo; a chuva, entretanto, com facilidade faz as pessoas voltarem à maloca. ${ }^{238}$

Para Propp, Bóreas e Onça, Sol e Chuva seriam a grandezas variáveis. Da mesma maneira, homens despirem-se e entrarem em casa seriam grandezas variáveis devidamente adaptadas às outras grandezas. Estas seriam os atributos daquelas. As grandezas constantes nesse caso seriam a disputa e a intenção de provocar uma mudança de comportamento em humanos. De maneira geral, a adaptação entre as grandezas variáveis poderia estabelecer um princípio de concordância de atributos. Assim, o comportamento da grandeza variável perdedora da disputa seria, num caso, o ronco assustador e, no outro, a temperatura desconfortável. Se no primeiro caso, o ronco desencadearia um comportamento de caça nos homens, no segundo, desencadearia um comportamento de 
proteção contra o frio, agasalhando-se mais e mais. Essa concordância de atributo exige uma reflexão sobre o fenômeno que vai preencher o "slot" da grandeza variável. Trata-se, portanto, de um processo em que a sociedade reflete sobre si mesma. Se a grandeza "ronco da onça" desencadeia um comportamento de caça nos homens, é porque existe a expectativa de que o "ronco da onça" poderia amedrontar mais do que estimular a caça. Nesse caso, é de se pensar que a sociedade entende que o medo possa ser instaurado pelo ronco da onça, mas o que se preconiza é um comportamento diferente, de enfrentamento.

Mesmo que essa narrativa taulipang possa ser uma adaptação de outra, deve-se entender que o propósito com que foi usada não precisa corresponder ao propósito original. 0 suporte narrativo utilizado serve apenas como o mnemônico que garante tanto a possibilidade de se fazer a narrativa, como obter a atenção dos ouvintes por se tratar de uma sequência de eventos consagrados pelo uso.

Em tempos mais recentes, Labov e Waletzky (1967) e Labov (1997) desenvolveram um modelo de análise de narrativa que permite aprofundar ainda mais nossa interpretação. Para eles, da mesma maneira que em Propp, a ordem sequencial das grandezas constantes seria um dos elementos fundamentais da narrativa. Os autores chamaram essa ordem sequencial de juntura temporal. Ou seja, as sentenças que portassem uma grandeza temporal estariam presas entre si por uma juntura temporal. 


\section{Narrativas}

Essa juntura temporal poderia estar manifesta lexicamente ou não. Suas manifestações léxicas seriam como daí, então, depois disso..., dentre muitas outras possibilidades. As sentenças que portassem essas grandezas deveriam estar em modo realis, que seria o modo indicativo passado, ou presente com função de passado. A juntura, entretanto, poderia não estar manifesta no léxico sentencial. Nesse caso a correlação entre ordem cronológica e ordem gráfica das sentenças estabeleceria a juntura temporal. Sentenças que não tivessem juntura temporal seriam livres e poderiam aparecer em qualquer posição da narrativa e não têm um evento descrito em modo realis.

Ao propor a noção de "causalidade" para a análise de narrativas, Labov vinculou-a à de "relatabilidade" [reportability] de um exemplo. Para ele, segundo sua própria definição, “Um evento relatável é aquele que justifica a automática reatribuição do papel de falante ao narrador", isto é, a relatabilidade de um evento seria a qualidade que justificaria a reatribuição automática de turno ao falante que faz uma narrativa. ${ }^{239}$ Labov propôs essa noção de relatabilidade, imaginando que a narrativa estaria ocorrendo em uma situação de fala espontânea, numa conversa; daí a ideia de reatribuição do papel de falante, ou de reatribuição de turno. ${ }^{240}$ De fato, como ele próprio afirmou um pouco mais adiante, tratava-se do interesse que a narrativa desperta nos interlocutores. Ela deveria, portanto, estimular a curiosidade, criando expectativas nos interlo- 
cutores. Retomando, então, a noção de relatabilidade, esta se referiria exatamente ao grau de expectativa que uma narrativa despertaria em seus interlocutores. Se o evento seguinte sempre ocorrer conforme o previsto pelo senso comum, haverá frustração, se não ocorrer conforme o esperado, haverá surpresa e a narrativa, pelo menos até esse ponto, terá sido bem-sucedida.

Conforme já vimos alhures, ${ }^{241}$ Labov (1997), ao reformular a proposta de Labov e Waletzky (1967), propôs que as sentenças de uma narrativa pudessem classificar-se estruturalmente em sentenças resumo, de orientação, de ação complicadora e coda. A sentenças resumo e coda seriam respectivamente a primeira e a última da narrativa. A sentenças de orientação e de ação complicadora merecem comentários mais detalhados.

De forma bastante resumida, Labov (1997) propôs que uma sentença de orientação pudesse resumir-se como:

Uma sentença de orientação dá informação sobre o tempo, lugar dos eventos de uma narrativa, a identidade dos participantes e seu comportamento inicial. 242

Podemos pensar, seguindo essa definição, que as sentenças de orientação têm um caráter eminentemente descritivo. São sentenças que tratam sobretudo do ambiente em que a narrativa vai transcorrer. Na narrativa que vai no fragmento de 


\section{Narrativas}

texto abaixo podemos observar um exemplo de sentença de orientação.

[...] levou a panela para o mato e enterrou-a. Ninguém sabia que ele tinha enterrado no mato uma panela cheia de arroz a não ser ele próprio e a filha.

Após duas sentenças de ação complicadora, o autor acrescentou a informação sobre o fato de que as ações anteriores eram desconhecidas de todos. Podemos perceber que não houve ação aí, mas tão somente um esclarecimento a respeito do que já tinha acontecido. Trata-se de uma informação que permanece constante durante ações anteriores e, possivelmente, futuras, no tempo do discurso, especialmente. Para que essa informação perca seu valor de verdade no contexto narrativo, algum evento teria de ocorrer especificamente para isso. Podemos entender as sentenças de orientação como a descrição de eventos que compõem o cenário da narrativa.

A definição de Labov (1997) para as sentenças de ação complicadora também é muito resumida.

Uma sentença de ação complicadora é uma sentença sequencial que relata um evento seguinte como resposta a uma questão potencial "E [então] o que aconteceu?"243

Na definição, o autor já restringe as sentenças de ação complicadora às sentenças sequenciais, isto é, aquelas que têm juntura temporal. Como nem sempre as junturas temporais estão lexicalizadas, seu reconhecimento suscita algum outro tipo de 
consideração, tal como aparece de forma subjetiva na definição feita do autor feita pela questão potencial: "E [então\} o que aconteceu?"

Bruner (1991) propôs uma característica para as narrativas que intitulou "Canonicidade e violação". Essa característica pressupõe que o desenvolvimento de uma narrativa se baseie no estabelecimento de regras, ou cânones como ele as chamou, que sejam sistematicamente quebradas. Desse ponto de vista:

[...] nem toda sucessão de eventos recontada constitui uma narrativa, mesmo quando é diacrônica, particular, e organizada a partir de estados intencionais. Alguns acontecimentos não justificam que se fale sobre eles e diz-se serem "sem-graça", e não uma história. [...]

Violações de cânones, como os enredos violados, são muitíssimo tradicionais e são fortemente influenciados pelas tradições narrativas. Tais violações são prontamente reconhecíveis como situações familiares humanas: a esposa traidora, o marido corneado, o inocente espoliado, e assim em diante. Novamente, eles são situações convencionais das narrativas. 244

Tomando a proposta de Bruner como complemento à de Labov (1997) - sobretudo quanto à pergunta "e então?" - , podemos entender que canonicidade e violação numa narrativa corresponderiam respectivamente à sentença que antecede e à que sucede uma juntura temporal. De certa maneira, poderíamos esperar que uma juntura temporal não marcada poderia ser lexicalizada pela adversativa "mas" da língua portuguesa. 


\section{Narrativas}

Se tomarmos uma narrativa mínima, isto é, composta por apenas duas sentenças ligadas por uma juntura temporal, podemos entender isso melhor.

Com a quimioterapia, seu cabelo havia caído quase todo. Agora, com a luta vencida, deixou crescer cabelo e barba como um velho hippie. 245

Se segmentarmos essa narrativa em suas sentenças de orientação (o), de ação complicadora (ac) e junturas temporais (jt), teremos o seguinte:

\section{Tabela 1}

$\begin{array}{lll} & \text { jt } & \text { Com a quimioterapia } \\ 1 & \text { ac } & \text { seu cabelo havia caído quase todo. } \\ & \text { jt } & \text { Agora, } \\ & \text { jt } & \text { com a luta vencida, } \\ 2 & \text { ac } & \text { deixou crescer cabelo e barba como um velho hippie. }\end{array}$

Os eventos descritos pela narrativa vão definidos pelos verbos de ação "cair" e "crescer". Tendo em vista que a exigência para que o evento "deixar crescer cabelo e barba" é que eles tivessem sido cortados em evento anterior, tal como vai na expressão "seu cabelo havia caído". Podemos entender, portanto, que a informação dada na sentença 1 é condição necessária para a sentença 2 . A canonicidade que ficaria estabelecida pela sentença 1 é que, "quando os cabelos caem, o indivíduo permanece sem seus cabelos". A sentença 2 viola essa canonicidade informando-nos que o indivíduo não ficou sem cabelos, mas, ao contrário, deixou-os crescer. 
A violação da canonicidade pode decorrer de fenômenos muito diversos. Normalmente ela aponta para o fato de que o evento anterior, por algum motivo social qualquer, teve de sofrer alguma mudança. Quando não ocorrem mudanças entre sentenças presas por uma juntura temporal, e a narrativa segue o senso comum, pode-se esperar que haja perda de interesse do interlocutor pela sequência dos eventos futuros a serem descritos nas sentenças.

Não seria possível nem prudente estabelecer a todas as sentenças sequenciais uma expectativa alta. $\mathrm{Na}$ maior parte das vezes, a expectativa é baixa ou inexistente. No entanto, por se tratar de um ato de narrativa, desde o início reconhecido como tal, há de haver uma expectativa intrínseca ao próprio ato. Labov referiu-se a esses fatos tomando-os como graus de relatabilidade e propôs que toda narrativa deveria conter um evento que seja o menos previsível, portanto de maior grau de relatabilidade. A esse evento específico, ele chamou de "evento mais relatável". Ele o definiu como o evento que é menos comum do que qualquer outro na narrativa e que teria um grande efeito nas necessidades e desejos dos participantes da narrativa. Para Labov, esse evento mais relatável seria praticamente a razão da existência da própria narrativa, ou seja, fez-se a narrativa para narrá-lo.

A posição de Labov para a análise das narrativas pessoais ia bem ao encontro do modelo tradicional de análise do drama, proposto como "pirâmide de 


\section{Narrativas}

Freitag". Segundo esse modelo, proposto por Gustav Freitag (1816-1895), em 1863, o drama se formaria por linhas, estabelecendo uma estrutura piramidal. Cresceria na introdução, com a entrada de forças emocionantes para atingir o clímax e cairia, a partir daí, para a catástrofe. Para ele, o clímax seria o ponto no drama em que os resultados do movimento crescente viriam mais fortes e mais decisivamente; sendo, quase sempre, o ponto culminante em uma cena, que se cercaria de cenas menores de ascensão e queda da ação.

A proposição laboviana de evento mais relatável seria, pois, o clímax freitaguiano aplicado a uma narrativa pessoal, obviamente, guardadas as devidas proporções. Nas obras dramáticas se esperaria que eventos grandes e inesperados ocorressem promovendo emoções igualmente grandes e inesperadas para o júbilo de seus receptores; nas narrativas pessoais feitas pelas pessoas comuns, que não elaborariam nem sofisticariam sua experiência pessoal, não se haveria de esperar emoções elaboradas e sofisticadas, mas, tão somente, as mais comuns e mais adequadas ao próprio momento em que são feitas. No entanto, o tratamento teórico pode ser feito de forma semelhante, o que abre as possibilidades de o modelo de Labov ser aplicado também a outras formas narrativas que não as estritamente pessoais e orais.

A causalidade proposta por Labov para a narrativa teria a ver, portanto, mais especificamente, com a 
expectativa do clímax que será alcançado pelo movimento ascendente das sentenças sequenciais de ação complicadora. De certa maneira, por não ser possível atribuir alto grau de expectativa a cada par sentencial, como já vimos, mas somente àquele que contiver o evento mais relatável, haverá maior dificuldade em se detectar a causalidade nas sentenças de ação complicadoras que antecedam o clímax.

Se partirmos da hipótese que vimos mais atrás de que grande parte dos fatos sociais são fenômenos discursivos, desencadeados pelas propriedades que a linguagem simbólica humana apresenta, o domínio da linguagem torna-se uma das estratégias principais para a vida em sociedade. 0 conhecimento linguístico nesse conjunto de linguagens disponível é um dos que apresenta maior abrangência, sendo devedor somente das lingua-gens que se compõem de várias linguagens a um só tempo, como a das representações teatrais ou a das representações cinematográficas.

0 estudo da língua nesse contexto contribui de forma muito significativa para a compreensão das manifestações narrativas que, conforme nossa proposta neste livro, atuam estabelecendo, mantendo, modificando e destruindo os diferentes papéis correspondentes aos status criados como fatos sociais. 0 trabalho de Labov e Waletzky (1967) se desenvolveu exatamente no sentido de apresentar técnicas próprias para a análise de narrativas pessoais. A restrição referente a 


\section{Narrativas}

narrativas "pessoais" decorreu do fato de sua proposta teórica basear-se especialmente nas narrativas que foram usadas para o desenvolvimento dessa técnica. Os dados que compuseram o material de análise foram extraídos de entrevistas tomadas de indivíduos que se dispunham a falar num gravador como sujeitos de uma pesquisa experimental de sociolinguística. As narrativas, portanto, eram incidentais. Eram indivíduos que não tinham como especialidade fazer narrativa nem mesmo serem contadores de histórias, mas, ao contrário, suas narrativas, bem como sua linguagem, entravam no contexto das sensibilidades múltiplas, bastante adequadas às manifestações orais espontâneas. Eram tão somente falantes proficientes na língua. As enunciações eram todas orais. A proposta de análise era voltada para essas narrativas pessoais, orais, improvisadas.

Nesta nossa proposta, vamos muito além disso. As narrativas que pretendemos discutir têm origem das mais diversas. Envolvem textos advindos de transcrição de narrativas orais tradicionais, narrativas tradicionais reescritas, narrativas escritas na internet, textos literários curtos e letras de música. A aplicação da técnica de análise de Labov e Waletzky (1967) e de Labov (1997) deverá ser feita com algumas adaptações.

Como já vimos, um dos critérios estabelecidos por eles é o da correlação do encadeamento sentencial e a sequência temporal dos eventos. Isso foi objeto de discussão em Genette (1990). A partir dessa 
discussão, Genette concluiu que esse critério de correlação não conseguiria se sustentar na comparação entre narrativas fictícias e narrativas factuais. Tendo em vista que Labov e Waletzky (1967) pressupunham que as narrativas pessoais que estabeleceram como padrão para suas análises eram factuais, entendemos que se possa estender essa conclusão para a indiferenciação entre narrativas pessoais e demais narrativas.

A formalização da ordem das sentenças pelo conceito de juntura temporal estabelece também a articulação entre sentenças sequenciais de ação complicadora. Num exemplo bem simples, como na narrativa abaixo, podemos ver isso.

\section{Texto 5: Fui fazer ovo frito}

Hoje fui fazer ovo frito, mas a gema quebrou; fiz mexido. ${ }^{246}$

Se separarmos as sentenças dessa narrativa, teremos:

\section{Tabela 2}

1 hoje fui fazer ovo frito

2 mas a gema quebrou

3 fiz mexido

Nesse exemplo, temos duas junturas temporais: uma entre as sentenças 1 e 2 e outra entre as sentenças 2 e 3 . A juntura temporal é o que garante a correlação entre a ordem das sentenças e a ordem dos eventos, tal como ocorreu no exemplo. A ordem dos eventos é definida por fatos externos à linguagem, como já salientou Propp, quando tratou 


\section{Narrativas}

da relação entre o roubo e o arrombamento da porta. A ordem das sentenças, por sua vez, é definida por intenções estilísticas que atingem especialmente o Sinn fregiano da narrativa. Poderíamos refazer a narrativa que usamos acima:

\section{Texto 6: Fiz ovo mexido}

Hoje fiz ovo mexido, porque a gema quebrou quando fui fazer ovo frito.

Note-se que, separando as sentenças, a ordem das sentenças inverteu a ordem dos eventos, marcados com número entre parênteses:

\section{Tabela 3}

$\begin{array}{lll}1 & (3) & \text { hoje fiz ovo mexido } \\ 2 & (2) & \text { porque a gema quebrou } \\ 3 & (1) & \text { quando fui fazer ovo frito }\end{array}$

Essa ordem dos eventos faz parte do Bedeutung da narrativa e não do Sinn. Ainda que a narrativa não tenha de ter necessariamente um compromisso com a realidade, ela tem de ter relatabilidade, nos termos de Labov (1997), isto é, o interlocutor tem de ser convencido de que os eventos descritos nas sentenças realmente ocorreram. Lembremos que os interpretantes de uma narrativa ficcional se desenvolvem a partir da iconicidade das sentenças, isto é, são símbolos que têm como objeto seu próprio representamem. No caso das narrativas, tal como as estamos tratando aqui, os interpretantes são gerados pelo fato de os eventos serem as próprias sentenças, com todas suas características linguísticas. Assim, toda a responsabilidade da 
manutenção da relatabilidade da narrativa recai sobre a formação interna das sentenças e pelas articulações das sentenças entre si.

Os eventos de uma narrativa podem ocorrer em momentos sucessivos, de forma linear, ou simultaneamente. A correlação positiva entre a sucessão de eventos e a das sentenças facilita a percepção das junturas temporais não lexicalizadas, pois essas decorrem da mera sequência das sentenças. A simultaneidade dos eventos, entretanto, exige o desenvolvimento de estratégias linguísticas mais específicas. Essas estratégias constituem o que se chama de aspectualização. 0 conceito de aspecto, apesar de ser fundamental para a compreensão de narrativas e fazer parte do conhecimento de qualquer falante proficiente na língua, é pouco explorado nos estudos gramaticais escolares. Vargas (2011) considera a noção de aspecto no discurso:

A necessidade de o falante procurar retratar (no sentido de representar algo, de descrever com exatidão) o que [ele] quer que seu interlocutor interprete ou assimile é sinal de que pretende provocar o ouvinte/leitor, ou seja, de que pretende que esse interlocutor interfira na construção do sentido daquilo que ele, sujeito do discurso, diz. Nesse sentido, essa opção por uma forma aspectual revela-se como um modo de manifestação da subjetividade no discurso produzido.

0 aspecto depende, portanto, de como o falante concebe a situação e de como quer expressá-la. ${ }^{247}$ 


\section{Narrativas}

A autora salienta que o aspecto é uma opção do autor (que é chamado de "sujeito do discurso"), tratando-se, pois, de um recurso de estilo. Se retomarmos o Texto 4, podemos perceber que os eventos descritos nas sentenças 1 e 2 podem ser tratados como simultâneos, como seriam em:

\section{Texto 7}

Hoje, quando estava fazendo ovo frito, a gema quebrou; fiz mexido.

É bastante evidente, nesse caso, a opção do autor pela simultaneidade (cf. Texto 5). Conforme Vargas (2011), essa é uma opção de estilo. A expressão que vai na sentença 1 - "Fui fazer ovo frito" - poderia ser substituída por "quando estava fazendo ovo frito", "assim que comecei a fazer ovo frito", "enquanto eu fazia ovo frito". Há muitas outras opções que envolveriam mudanças no conjunto da expressão "na hora em que o ovo começou a fritar", "enquanto o ovo estava fritando", dentre outras -, cada qual apresentando alguma pequena variação de ênfase numa ou noutra etapa do evento descrito. Todas as variações, entretanto, mantêm a descrição do mesmo evento no mesmo momento do passado.

Tendo em vista que a proposta era a de produzir uma narrativa em que não houvesse evento mais relatável, a opção do autor foi a de deixar o texto quase inteiramente de forma não marcada. Se fizermos um levantamento quantitativo considerando a frequência de uso das conjunções adversativas - mas, porém, entretanto, contudo, todavia e 
no entanto 248 - em textos de autores consagrados, ${ }^{249}$ teremos os seguintes resultados:

\begin{tabular}{|c|c|c|c|c|c|}
\hline & $\begin{array}{l}\text { Lima } \\
\text { Barreto }\end{array}$ & $\begin{array}{l}\text { Euclides } \\
\text { da Cunha }\end{array}$ & $\begin{array}{l}\text { Machado } \\
\text { de Assis }\end{array}$ & $\begin{array}{l}\text { Aluisio } \\
\text { Azevedo }\end{array}$ & $\begin{array}{l}\text { Rui } \\
\text { Barbosa }\end{array}$ \\
\hline mas & 1390 & 462 & 1792 & 1351 & 802 \\
\hline porém & 264 & 212 & 92 & 277 & 131 \\
\hline entretanto & 160 & 103 & 67 & 122 & 61 \\
\hline contudo & 27 & 15 & 40 & 23 & 13 \\
\hline todavia & 0 & 11 & 14 & 72 & 32 \\
\hline no entanto & 7 & 14 & 1 & 22 & 0 \\
\hline & 1848 & 817 & 2006 & 1867 & 1039 \\
\hline
\end{tabular}

Essa tabela, convertida num histograma de frequências, pode dar uma visualização melhor:

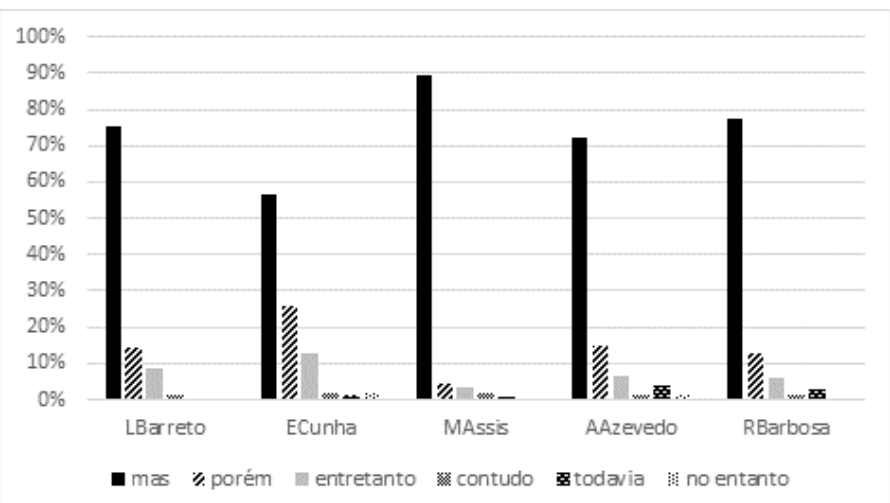

O histograma mostra que o uso da conjunção "mas" é proporcionalmente maior do que o das demais, concorrendo, ainda que com alguma distância, apenas com o uso da conjunção "porém". Ainda que possamos imaginar que se trate de uma opção de cada autor, a unanimidade entre esses autores aponta para o fato de que "mas" é a forma mais comum de se marcar lexicamente a adversidade que 


\section{Narrativas}

se pretende demonstrar entre duas sentenças. É de se esperar que as formas mais comuns sejam imperceptíveis e, portanto, não interfiram na formação dos interpretantes, trazendo o leitor de volta para a locução ou para o locutor. A ausência desse tipo de marca, por sua vez, poderia trazer alguma dificuldade para o leitor na percepção de que se trata da fuga de uma hipotética canonicidade prevista na primeira sentença: "quem frita um ovo, deixa a gema inteira". A quebra da canonicidade foi apontada pelo conectivo. 0 senso comum não necessariamente estabelece que ovos fritos tenham de ter gemas inteiras, que não possam estar quebradas. Nesse caso, específico, pode ser que se trate da marca de uma idiossincrasia desse autor, que mostra suas preferências culinárias. A sentença 2 do Texto 4 é uma sentença de ação complicadora, garantindo a continuidade da narrativa na direção de um evento mais relatável. A solução da narrativa, isto é, o evento mais relatável, apesar de sua relatabilidade fraca, vai na sentença 3 .

No exemplo do Texto 6, a ordem dos eventos apresentada no Texto 5 continua sendo a mesma, apesar de terem sido apresentados numa sequência sentencial que desfaz a correlação positiva prevista para uma narrativa pessoal. A variação estilística que atinge somente o Sinn de Frege, ou a mensagem de Jakobson, pode ter consequências diretas na maneira como as sentenças serão interpretadas pelo interlocutor. 
A proposta de Austin (1990) quanto à noção de força ilocucionária pode ser esclarecedora. Esse autor propôs que houvesse três graus de força ilocucionária: o primeiro, que podemos chamar de grau zero, seria a mera locução, em que o enunciado seria tratado exclusivamente por suas referências específicas que, do ponto de vista que temos usado aqui, seriam o Bedeutung de Frege, ou os objetos de Peirce, ou ainda o referente de Jakobson; o segundo grau, que Austin tratou como ilocucionário, seria aquele sobre o qual incidiriam intenções para além do grau zero da força ilocucionária, ou seja, ultrapassariam a mera consideração referencial, obrigando o interlocutor a interpretar a locução feita a partir de elementos que extrapolariam as referências lexicais do enunciado; o terceiro grau, que Austin chamou de perlo-cucionário - que já vimos anteriormente - , seriam os que envolveriam uma completa mudança de comportamento, apenas por terem sido proferidos.

0 caráter referencial das sentenças narrativas é o dos enunciados descritivos com grau zero de força ilocucionária. As sentenças narrativas se consideram especialmente por sua força ilocucionária de grau zero; é importante frisar isso. As variações estilísticas que envolvem o Sinn, ou a mensagem, da sentença decorrem de fatos que extrapolam o nível referencial. Assim, tanto podem decorrer de variação na própria identidade do falante - por conta de variações dialetais, ou de status social por exemplo - como de variações expressivas - para 


\section{Narrativas}

dar maior destaque a uma ou outra expressão na sentença - ou ainda para propor uma variação de significação, como a ironia. São muitas as possibilidades a serem definidas especialmente no momento de sua ocorrência.

Como vimos no exemplo do Texto 5, sua força ilocucionária de grau zero nos levaria somente a interpretar as referências, mas a força de um enunciado ilocucionário seria atingida ao tomarmos que houve uma intenção malsucedida do narrador, que quebrou a gema de seu ovo e, então, teve de se conformar com ovo mexido. Mais do que as meras referências, será preciso reconhecer aí um caráter emocional de frustração, ainda que muito pequeno, para o usufruto da narrativa como leitor-modelo.

Essa possibilidade de várias interpretações para um mesmo enunciado é uma característica do interlocutor que não precisa ser compartilhada com o autor. É comum que, durante a elaboração do enunciado, o autor tenha de forma clara a informação, o bedeutung, que deseja manifestar. Há casos, como nas manifestações artísticas, por exemplo, em que a duplicidade de sentido é proposital. Não se trata, porém, do uso comum da linguagem. Desse ponto de vista, a ambiguidade é um fenômeno relacionado com o interlocutor. Jakobson foi um dos que tratou desse aspecto da linguagem de maneira bastante esclarecedora.

Grosso modo, o processo de codificação vai do sentido ao som, e do nível léxico-gramatical ao nível fonológico, enquanto que o processo de 
decodificação exibe direção inversa - da soma ao sentido e dos elementos aos símbolos. Enquanto que a orientação ('Einstellung, set') para os constituintes imediatos está em primeiro plano na produção do discurso, para a sua percepção a mensagem é antes de tudo um processo estocástico. 0 aspecto probabilístico do discurso encontra insigne expressão na maneira pela qual o ouvinte considera os homônimos, ao passo que, para quem fala, a homonímia não existe. Quando se diz "vão", sabe-se de antemão se se quer dizer "vão" (adjetivo) ou "vão" (do verbo 'ir'), ao passo que o ouvinte depende das probabilidades condicionais do contexto. Para o receptor, a mensagem apresenta grande número de ambiguidades onde não havia qualquer equívoco para o emissor. As ambiguidades do trocadilho e da poesia utilizam, para a emissão, esta propriedade da recepção. ${ }^{250}$

Será, portanto, responsabilidade do leitor do Texto 5 optar entre os sentidos que ele puder extrair das sentenças e, assim, alcançar o nível ilocucionário do enunciado, em que se reconhecem as intenções do autor/narrador, ultrapassando o nível das referências lexicais. Bruner chamou a atenção para o fato de que a percepção da intenção "não parece requerer para seu reconhecimento nenhum ato interpretativo complexo ou sofisticado por parte de quem a presencia". ${ }^{251}$ Isso, porque ele considerava que as narrativas tratam especificamente das vicissitudes da intenção, ou seja, somente a partir do momento em que o interlocutor consegue decodificar o grau zero da força ilocucionária do enunciado - porque é proficiente na língua - e 


\section{Narrativas}

atribuir uma intenção às atitudes das personagens - porque consegue encontrar similitudes com sua experiência de senso comum armazenada - é que a narrativa atinge seu propósito.

Como vimos no Texto 5 acima, para uma compreensão mínima, é necessário saber que, ao fritar ovos, a gema intacta é preferível, uma vez que a conjunção atua no sentido de salientar que o evento ocorrido não era o esperado. Assim, podemos pressupor o senso comum, tanto do autor como o do interlocutor, de que ovos fritos ideais são os que mantêm a gema intacta. Nesse caso, e somente nesse caso, a narrativa poderia encaixar-se na proposta do site de que seria uma história sem graça, isto é, sem nenhuma informação inesperada.

A ordem dos eventos é imutável e é ela que, a princípio, deve estabelecer a base para a compreensão geral da narrativa. Leve-se em consideração que essa sequência de eventos só pode ser percebida após o término da enunciação da narrativa. Para Labov (1997), esse é um risco a se correr quando houver necessidade de manutenção de turno, diante de interlocutores, ou de manutenção da atenção do leitor. A segmentação da narrativa em suas articulações, entretanto, nem sempre se adéqua à disposição das sentenças. No exemplo abaixo, retirado da narrativa "O mito do Sol" podemos ver isso.

\section{Texto 8}

A velha, pensando que ele morreria, disse: "Bebe, bebe logo". 
São duas sentenças que portam eventos diferentes. A primeira é "a velha disse: 'bebe, bebe logo'” e a segunda, que vai intercalada na primeira, é "pensando que ele morreria". A sentença intercalada é a causa da primeira, ou seja, "porque pensou que ele morreria, a velha disse "bebe, bebe logo'”. A intenção, nesse caso - a de que o sobrinho morresse - , se estabelece apenas pela justaposição das sentenças. A construção de sentenças intercaladas - uma das estratégias sintáticas disponíveis na língua portuguesa - reforça o fato de que o evento descrito na primeira sentença ocorreu durante todo o evento descrito na segunda sentença e é, portanto, uma estratégia estilística que não envolve o bedeutung. A simultaneidade dos eventos, estabelecida para uma mesma personagem, atua de forma semelhante à da sequenciação das sentenças. Para dar esse efeito de simultaneidade de dois eventos, o autor valeu-se do gerúndio que é uma das formas verbais com aspecto imperfectivo cursivo. ${ }^{252}$

Tabela 4

$\begin{array}{ll}1 & \text { (2) a velha disse: "bebe, bebe logo } \\ 2 & \text { (1) pensando que ele morreria }\end{array}$

A segmentação, nesse caso, deve prescindir do percurso temporal ou causal dos eventos, sobretudo porque é a formação da mensagem, do Sinn, que representa a intenção do autor, no momento da enunciação. Nesse caso específico, trata-se de uma oração que pode ocupar diferentes posições em relação à primeira oração. Esse fato garante que a sentença "pensando que ele morreria" tem o caráter 


\section{Narrativas}

de sentença livre de ação orientadora, porque não se articula com a primeira por meio de uma juntura temporal.

Texto 9: fragmento de "As relações com o Paí"

...em casa, descansa na sua rede, aparece de novo

o Paí em forma feminina, quando a mulher do homem está ocupada, e o desafia com audácia...

Nesse outro fragmento, extraído do texto "As relações com o Paí", a situação sintática das sentenças é semelhante.

\section{Tabela 5}

$\begin{array}{ccl}1 & (1) & \text { em casa, descansa na sua rede } \\ 2 & (1) & \text { aparece de novo o Paí em forma feminina } \\ 3 & (1) \sim(2) & \text { quando a mulher do homem está ocupada } \\ 4 & (3) & \text { e o desafia com audácia }\end{array}$

A sequência sentencial é linear, sem intercalações. A sequência dos eventos, entretanto não apresenta a mesma linearidade. 0 momento (1) do evento descrito pela sentença 1 é o mesmo do evento descrito pela sentença $2 \mathrm{e}$, aparentemente, também o do evento descrito respectivamente pela sentença 3 . Pode-se entender que o Paí aparece enquanto o homem descansa na sua rede e sua mulher está ocupada. 0 evento descrito pela sentença 4 tem de ser posterior ao evento descrito pela sentença 2 , isto é, primeiro o Paí aparece, depois ele desafia o homem e tudo isso ocorre enquanto o homem está descansando e sua mulher está ocupada.

Mas, há outra possibilidade, o evento descrito pela sentença 3 é simultâneo ao evento descrito pela 
sentença 4, mas, posterior ao evento descrito pela sentença 2, isto é, o Paí espera que a mulher do homem fique ocupada para, então, desafiá-lo com audácia.

Em qualquer dos casos, é responsabilidade do interlocutor decidir sobre a ordem dos eventos. Obviamente isso pode ser um problema para a manutenção do turno do locutor ou para a manutenção da atenção do interlocutor. A confusão na formação dos interpretantes faz com que o interlocutor passe a considerar somente o locutor, isto é, os representamina de Peirce.

A inversão na ordem dos eventos, pode aparecer marcada por formas temporais como "enquanto", "durante", "antes disso", dentre muitas outras, ou, no caso do português, por formas verbais. É o caso de flexões ou perífrases verbais que diferenciam o que Ilari (1997) chama de momento de referência (MR), momento de realização do evento (ME) e momento de fala (MF) ${ }^{253}$. 0 momento da fala seria mais propriamente o tempo da enunciação, conforme a proposição de Benveniste (1974), que vai representado simbolicamente no texto pela figura do narrador, conforme a proposição de Genette (1972). Desse ponto de vista, o alinhamento entre esses três momentos, isto é, $M F=M R=M E$, apontariam para o tempo presente, aquela fração de segundo que é geralmente definida como a espessura do presente. 254 É um tempo completamente inusual se não vier acompanhado de uma descrição de duração, de aspecto verbal. Em 


\section{Narrativas}

narrativas, a referência a eventos passados é sempre predominante, no entanto, nem todos os verbos vão flexionados dessa maneira, em português. Assim, a flexão verbal da sentença narrativa e o tempo de realização do evento nem sempre têm uma adequação mútua. Nesse caso, o que importa é o tempo de realização do evento.

\section{Texto 10}

Samara acorda de manhã com um telefonema de seus amigos chamando-a para acampar. Ela muito animada diz que sim e vai correndo até a mãe contar a notícia.

No fragmento do texto "Aviso de mãe", temos uma sequência sentencial correlata com a sequência de eventos que descrevem:

$\begin{array}{ll}1 & \text { (1) Samara acorda de manhã com um telefonema } \\ 2 & \text { (2) chamando-a para acampar } \\ 3 & \text { (3) ela muito animada diz que sim } \\ 4 & \text { (4) e vai correndo até a mãe contar a notícia }\end{array}$

Os verbos, nas sentenças 1, 3 e 4 vão flexionados no presente do indicativo "acorda", "diz" e "vai". Tratase de uma opção estilística do autor, possivelmente para obter algum efeito expressivo, como um maior dinamismo na sequência de ações. A opção pela flexão do passado daria o resultado:

\section{Texto 11}

Samara acordou de manhã com um telefonema de seus amigos chamando-a para acampar. Ela muito animada disse que sim e foi correndo até a mãe contar a notícia 
Se aceitarmos a hipótese de que o presente tem uma duração de milésimos de segundo, que seria também hipoteticamente descrita pela própria flexão do presente, podemos imaginar que uma narrativa formada dessa maneira desencadeie interpretantes que simulem uma percepção em tempo real. Comparando o Texto 10 e o Texto 11 entre si, é fácil perceber que o uso das flexões do presente no Texto 10, o original, imprime maior velocidade à realização dos eventos. Vargas (2011) lembra ainda que a substituição das flexões do pretérito pelas do presente "promove, sem dúvida, um marcante efeito de 'presença', ou seja, de construção de sentido compartilhada pelo interlocutor, de modo simultâneo, intemporal." 255 Trata-se, portanto, de uma opção estilística do autor que pode provocar variações interpretativas por parte do interlocutor que não afetam os eventos que vão descritos nas sentenças. Como vimos anteriormente, as variações de estilo atingem somente as sentenças no seu grau mais baixo de força ilocucionária. A sentença tem de ser transparente, assim como seu locutor, caso contrário a narrativa estará comprometida pelo desaparecimento dos interpretantes do interlocutor.

O compartilhamento do mesmo código linguístico e das mais diferentes crenças que compõem o senso comum tem de estar presente para que a narrativa possa atingir seus propósitos. 


\section{Narrativas}

Retomemos o Texto 4, como exemplo. A narrativa apresenta logo no início uma expressão "sec hj" 'século hoje' que não só tem o propósito de datar os acontecimentos, como de servir de marca de início de narrativa pessoal, padronizada pelo grupo no site de relacionamento pessoal de onde foi extraída. Parece ter função semelhante ao "era uma vez...", de contos de fadas, ou ao "essa história aconteceu com um amigo de um amigo meu...", de narrativas cuja veracidade já é dada como incerta desde o início. Enfim, trata-se de um indicativo de que virá, a seguir, uma narrativa.
i) vindo da casa da pitanga
ii) decido comprar um cachorro quente no meio do caminho
iii) venho comendo o cachorro quente no caminho
iv) do nada aparece um mlk gigante gritando PERDEU PERDEU
v) este filho da puta vai levar meu dinheiro e celular
vi) pegou o resto do meu cachorro quente e guaraná e saiu comendo

Labov propôs que a sentença narrativa composta pelas sentenças de ação complicadora pudesse isolar-se de seus acidentes, tais como as junturas temporais expressas e as sentenças de orientação. As sentenças de orientação não têm juntura temporal e atuariam somente para caracterizar a cena e as personagens. No exemplo, há algumas expressões não formadas como sentenças, e também sentenças completas que têm essa função orientadora. Temos as sentenças (1) "sec hj", (5) "feliz pra caralho comendo meu cachorro quente", (7) "tranquei o cu, não passava nem wifi", (10) "to até agora sem entender q porra aconteceu cmg" e (11) "acho q vou registrar um b.o pra recuperar meu 
cachorro quente"; e as expressões em (2) "de boa" e (8) "fudeu"; todas são de ação orientadora e, com exceção da primeira, têm como função apresentar o estado emocional do herói, que, no caso, é o próprio narrador.

Nessa sequência de sentenças, as três primeiras apenas apresentam um evento corriqueiro, quase previsível. Por se tratar de uma narrativa, anunciada em "sec jh", há, desde o início, a expectativa de um evento mais relatável que, de certa maneira, é retardado pelas sentenças de ação complicadora de menor grau de expectativa que o antecedem. Podemos imaginar uma relação de causalidade entre (i) e (ii), estabelecendo uma regra geral do senso comum do tipo "quem vem de algum lugar chega a seu destino". Caso a sentença seguinte a (i) tivesse como evento a chegada ao destino pelo herói, não haveria surpresa, pois a curiosidade era "0 herói chegará ao seu destino?", mas com um grau bem baixo de relatabilidade. A dúvida decorre especialmente do uso do aspecto verbal contínuo, marcado pelo gerúndio \{-ndo\}. Trata-se do prolongamento de uma ação no tempo narrativo, apontando para o fato de que o interlocutor tem de imaginar um evento que está em curso, que ainda não terminou. A sentença (ii) mostra que o herói não chegou ao seu destino porque a ação foi interrompida pelo evento da compra do cachorro quente; o que, por sua vez, gera a curiosidade " 0 herói comerá seu cachorro quente?", pois a regra geral prevista pelo senso comum seria "quem 


\section{Narrativas}

compra um cachorro quente come o cachorro quente que comprou". A sentença seguinte apresenta o evento esperado, mas, novamente, valendo-se do mesmo recurso linguístico do aspecto verbal contínuo para indicar uma ação em curso, o que gera a dúvida: "O que ocorrerá enquanto o herói come seu cachorro quente?". A sentença (vi) descreve as cenas iniciais de um assalto durante o evento em curso descrito na sentença (iii). Um assalto sempre gera tensão por se tratar de um ato realizado com ameaça de violência. A expectativa comum é a que o próprio narrador descreve na sentença (v), na forma de um pensamento não expresso, de que o celular e o dinheiro serão roubados. Caso a sentença seguinte apresente esse evento, não haverá surpresa e a narrativa ou terá continuidade ou terá sido somente um lugar comum que descreve experiências e sensações que todos já conhecem. 0 fato é que a sentença (vi) apresenta o evento inusitado de o herói ter sido roubado somente quanto ao cachorro quente meio comido e ao guaraná meio bebido. Trata-se, portanto, do evento mais relatável, ou seja, o clímax da narrativa, na medida em que era uma consequência totalmente inesperada. 
Waldemar Ferreira Netto 


\section{ALGUMAS ANÁLISES}

\section{Texto 12: A cabeça sem corpo}

Antigamente, quando as pessoas surgiram no mundo, começaram a caçar, até que apareceu uma cabeça que as perseguia. Não tinha corpo, era só cabeça.

Um homem foi caçar. Escureceu no mato, quando o caçador vinha voltando, e a cabeça sem corpo saiu no seu caminho, rolando, correndo. Jogou-se em cima do homem, seu dente mordia, comeu-o todo.

Todos o procuraram, e sua mulher foi lá ver onde ele estava. Aí a cabeça apareceu no meio do caminho. Jogava-se nas pernas das pessoas para derrubá-las, e aí comia tudo. A mulher morreu também.

Os homens, já quase se acabando, perceberam o que acontecia. Resolveram fazer um buraco para acabar com a cabeça. O tuxaua mandou um caçador:

- Vamos fazer um buraco bem fundo. Você tem que correr muito, quando escurecer. Passe o buraco, e fique lá. Quando a cabeça cair, você põe pedra em cima.

Dito e feito. 0 caçador foi. Escureceu, e a cabeça apareceu. 0 homem correu. Quando cruzou o buraco, a cabeça, rolando, caiu. Não tinha pé, nem perna para sair. Os homens jogaram pedra, pau e terra no buraco, e taparam a cabeça. Aí acabaram as mortes. ${ }^{256}$ 
Se observarmos a primeira frase da narrativa, que vai da primeira maiúscula ao primeiro ponto, podemos entender que há sentenças que descrevem eventos efetivamente e que há informações complementares que apenas nos orientam para formar nossos interpretantes desses eventos. Assim, se marcarmos em cinza essas orientações e em preto os eventos de ação complicadora, teremos:

Antigamente, quando as pessoas surgiram no mundo, começaram a caçar, até que apareceu uma cabeça que as perseguia.

As expressões em cinza "antigamente", "quando", "no mundo" e "até que" caracterizam-se como junturas temporais lexicalizadas ou como descritivos de situação, de cenário, em que as ações complicadoras se desenvolverão. É o caso de "no mundo" e "Antigamente". Por iniciar a narrativa, esta última deve ser vista com mais detalhamento.

Da mesma maneira que a narrativa que vai no Texto 4, em que a expressão "sec hj" indicava que a seguir viria uma narrativa, a expressão "Antigamente", na narrativa do Texto 12, tem a mesma função. As sentenças descritivas, livres, que apenas apresentam caráter descritivo são: "Não tinha corpo, era só cabeça"; "[os homens] já quase se acabando" e "Vamos fazer um buraco bem fundo. Você tem que correr muito, quando escurecer. Passe o buraco, e fique lá. Quando a cabeça cair, você põe pedra em cima". Esta última sentença pode ser bem definida como sentença livre porque apresenta seus verbos no modo irrealis, que no português pode ser 


\section{Algumas análises}

caracterizado pelo subjuntivo. Trata-se de eventos que não ocorreram, estão apenas planejados, imaginados no desenvolvimento da narrativa. As sentenças presas são as que vão a seguir.

\section{Tabela 6}

1. as pessoas surgiram

2. começaram a caçar

3. apareceu uma cabeça que as perseguia.

4. Um homem foi caçar.

5. Escureceu no mato

6. o caçador vinha voltando

7. a cabeça sem corpo saiu no seu caminho,

8. rolando,

9. correndo.

10. Jogou-se em cima do homem,

11. seu dente mordia,

12. comeu-o todo.

13. Todos o procuraram

14. sua mulher foi lá ver onde ele estava.

15. a cabeça apareceu no meio do caminho.

16. Jogava-se nas pernas das pessoas para derrubá-las

17. comia tudo.

18. A mulher morreu também.

19. Os homens perceberam o que acontecia.

20. Resolveram fazer um buraco para acabar com a cabeça.

21. O tuxaua mandou um caçador.

22. 0 caçador foi.

23. Escureceu

24. a cabeça apareceu.

25. O homem correu.

26. cruzou o buraco,

27. a cabeça, rolando, caiu.

28. Os homens jogaram pedra, pau e terra no buraco

29. taparam a cabeça

30. acabaram as mortes. 
As sentenças presas estabelecem a sequência dos eventos propriamente ditos. As sentenças 1 e 2 mantêm entre si uma relação de causalidade que faz parte do senso comum do grupo em que a narrativa se produziu. Se existem pessoas, elas devem sobreviver e, para isso, é preciso caçar. A sentença 3, por sua vez, parece muito mais uma sentença livre. Ainda que exiba uma juntura temporal "até que", ela não parece ser uma consequência direta do evento "começaram a caçar". É digno de nota que uma cabeça sem corpo é exatamente o símbolo peirciano que dobra sobre si mesmo, ou o signo sem referência de Frege. 0 que nos chama a atenção é o sentido (Sinn). Qualquer figura monstruosa poderia aparecer e ameaçar a humanidade, mas essa forma escatológica, verdadeiro nonsense, parece ter um alcance um pouco maior no sentido de uma intenção estética, como é o caso da personagem Rubber, que é um pneu, do filme Rubber, ${ }^{257}$ pois nem sempre há somente a preocupação com a origem de todas as coisas, nem sempre as narrativas indígenas têm de ser somente míticas, podendo ocupar-se de outros propósitos, valendo-se de outros recursos linguísticos. ${ }^{258}$

A relação de causalidade entre 5 e 6 seria, aparentemente, óbvia: "quando escurece, o caçador volta para casa". Sem dúvida que isso poderia fazer parte do senso comum, no entanto a caça é profícua durante a noite. Mas, como já dissemos, temos de assumir o papel de leitor-modelo e aceitar o senso 


\section{Algumas análises}

comum que vai proposto na narrativa, acriticamente; pelo menos numa primeira leitura. Como na análise anterior, poderíamos pressupor um nível baixíssimo de relatabilidade: "ele vai chegar em casa?". A sequência previsível para a sentença 6 seria "quem volta para casa, chega em casa". Ora, não foi o que ocorreu. 0 homem que vinha voltando não chegou em casa. A subsequência sentencial 7-12 mostra uma sucessão de eventos inesperados, fortemente imagéticos. A sentença 7 "a cabeça sem corpo saiu no seu caminho" - exige uma solução para o interpretante criado na sentença 3. Não há no senso comum uma regra para o deslocamento espontâneo de cabeças sem corpo, assim a solução seria imaginá-las voando, caindo do céu, escorregando pela lama, ou rolando pelo chão. A sentença 8 supre a nossa dúvida: a cabeça chegou onde estava o caçador rolando rapidamente, como vai expresso, a seguir, na sentença 9. Nesse ponto, nosso interpretante está mais completo: é uma cabeça sem corpo que rola rapidamente pela mata quando escurece. A sentença 10 descreve o ataque: a cabeça é capaz de jogar-se em cima do homem. A cabeça salta! E morde! pelo menos é o que vai na sentença 11. A cabeça não somente morde e machuca, ela come sua vítima! Devora-a toda; é o que nos descreve a sentença 12, que então finaliza o ataque. É perceptível que se trata de uma narrativa, até agora, bem-sucedida. É uma narrativa de ação. Imaginá-la poderia até nos deixar exaustos, assustados. Há uma sucessão de eventos imprevistos, capazes de gerar muita expectativa 
entre os ouvintes. Talvez, nestes tempos em que há uma variedade midiática muito maior do que as disponíveis nas sociedades tradicionais, nada disso chame a atenção. Mas, se essas sequências nos fossem mostradas como filmes, imagens, teríamos uma impressão diferente. David Le Breton lembra-nos que "de longa data nossas sociedades ocidentais valorizam a audição e a visão, mas às vezes dando-lhes valores diferentes e dotando pouco a pouco a visão de uma superioridade que vai se impondo no mundo contemporâneo".

A ação se repete. Para buscar o desaparecido, cuja esposa é que sente sua falta, todos vão para a mata. A linearidade temporal parece ter se perdido, e a relação de causalidade se inverteu. Nem sempre a coerência na correlação entre a sequência das sentenças e a sequência dos eventos se mantém. Obviamente isso pode pesar contra a relatabilidade das sentenças. 0 interlocutor pode perder seus interpretantes todos, e a crença na narrativa, desaparecer. No caso de uma narrativa proposta durante um diálogo importante, o falante narrador arriscaria seu turno e, com isso, a sua narrativa. Mas, na subsequência 15-18, a ação se repete, como dissemos, com novas promessas de ação. A cabeça reaparece no meio do caminho e a expectativa, gerada pela lógica da própria narrativa, é que haja um novo ataque. E há. Conforme o esperado, na sentença 16, a cabeça se joga nas pernas das pessoas, e as derruba. No chão, a cabeça as devora completamente; é o que vai na sentença 17 . E o 


\section{Algumas análises}

ataque culmina com a morte da esposa do primeiro caçador a ser devorado.

A subsequência final 19-29, a mais longa, tem início com a elaboração de uma estratégia para derrotar a cabeça sem corpo. Os sobreviventes entendem o comportamento da cabeça sem corpo. A expectativa gerada pela narrativa é a de que encontrem meios para eliminar o monstro: "se existe um monstro que nos mata, temos de eliminá-lo" é a regra proposta. E é isso o que o narrador nos apresenta na sentença 20, satisfazendo-nos. A estratégia é um buraco. É razoável, porque temos um interpretante que rola pelo chão das matas. Criamos essa imagem ainda na sentença 8. Na sentença 21, retomamos a cena: vai um novo caçador seguindo a ordem do tuxaua. $\mathrm{Na}$ sentença 22, vemos que o caçador obedece a ordem. A relação de causalidade é também evidente: "se o tuxaua manda ir, o caçador vai". É um senso comum duvidoso, pois o autor usa um verbo inadequado para esse tipo de narrativa tradicional, mas, por ora, temos de aceitá-lo. A sequência dos eventos é a mesma. $\mathrm{Na}$ sentença 22, ficamos sabendo que escureceu e, como era de esperar, veio a cabeça sem corpo em seguida, logo na sentença 23. Nossa expectativa divide-se entre a salvação do caçador e a ferocidade da cabeça. Dentre as opções, somos brindados com a fuga, na sentença 25: o homem corre, cruza o buraco e a cabeça rolante cai. Novamente é uma sequência rápida de ações. É preciso correr rápido, pois nosso interpretante tem, desde a sentença 9, a imagem de uma cabeça que rola 
rapidamente pelo chão. E ainda salta. A lógica da narrativa nos permite prever que a cabeça possa sair do buraco e, novamente, devorar o caçador, porque a fizemos saltar na sentença 10. Mas a sentença 28 quebra essa expectativa: os homens jogam "pedra, pau e terra no buraco". E, como vai na sentença 29, a cabeça ficou coberta e não poderá mais sair dali. É o fim do monstro. A sentença 30 nos traz de volta a um mundo sem a cabeça sem corpo que mata os caçadores.

Ao que parece, algumas das relações de causalidade propostas na narrativa não parecem boas. A primeira é a que estabelece que, na caça, quando escurece, volta-se para casa. Pode ser assim, é verdade, mas é um princípio que não parece bom. Nas matas, os animais preferem sair à noite, justamente para evitar seus vários predadores. Obviamente que há os que saem durante o dia. Como são em menor número, é sempre melhor caçar durante a noite. É difícil justificar que uma narrativa tradicional priorize uma exceção como essa. Da mesma maneira, a hierarquia nas sociedades indígenas não se manifesta como a que existe nas sociedades ocidentais. Assim, o princípio de que "se o tuxaua manda ir, o caçador vai" não é necessariamente válido. Obviamente pode-se justificar isso com a dificuldade na manipulação da língua. Isso tanto pode ter ocorrido por se tratar de língua estrangeira ou por ser uma tradução, como pode ser uma tentativa de criar uma lógica na narrativa especialmente para o interlocutor. Seja qual for a 


\section{Algumas análises}

justificativa, o fato é que houve uma coautoria, voluntária ou involuntária, consciente ou inconsciente, que pode ser atribuída ao próprio locutor do texto.

Essa foi uma leitura. Outras tantas poderiam ser feitas. 0 que buscamos nessa leitura é o evento mais relatável, conforme a proposta de Labov (1997). Esse evento é o que vai descrito na finalização, quando o monstro é finalmente derrotado na sentença 29. No fim das contas, fizemos a troca: o locutor nos deu as emoções prometidas e nós lhe demos atenção e tempo de fala, que no caso específico foi tempo de leitura. Junto das emoções vieram também recomendações justificadas: cuidado ao andar pela mata no escuro, armadilhas desse tipo são boas para seres que correm no chão, é preciso estar atento quanto ao retorno dos que foram à mata. Mas também ficamos sabendo que os homens caçam, as mulheres ficam preocupadas com a demora de seus maridos e vão em busca deles, os homens se socorrem mutuamente e em grupo, há um tuxaua que cuida do grupo propondo soluções para os problemas que enfrentam. Não se trata apenas de um texto de entretenimento, há muita informação. A oferta de emoções é somente a estratégia para todo o resto.

As narrativas estabelecem uma reflexão sobre a sociedade feita pela própria sociedade, uma autorreflexão. Nesse caso, a narrativa pode assumir um papel descritivo, que permitirá que se tenha alguma experiência em situações inusitadas, seja 
por conta de uma cabeça sem corpo rolando, com fome, atrás das pessoas, seja por quaisquer outros motivos. As narrativas, nesse caso, sugerem respostas a isso. As narrativas podem assumir um papel normativo também. Nesse caso, elas não sugerem respostas a uma situação inesperada, mas sim estabelecem comportamentos canônicos que devem ser seguidos por todos.

Embora seja óbvio que uma narrativa de ficção "descreve pessoas em ação e o leitor quer saber como essas ações se desenvolvem", ${ }^{259}$ a interpretação de uma narrativa somente por suas sentenças de ação complicadora não parece dar conta por si só da formação dos interpretantes do leitor-modelo. Vimos em diversos momentos que o autor precisa orientar seu interlocutor quanto à composição de seus interpretantes. As estratégias linguísticas da aspectualização, da variação de uso entre expressões mais corriqueiras, comuns a todos os interlocutores, também chamadas de não marcadas, a ordem das sentenças correlatas ou não com a ordem dos eventos, dentre outras possibilidades, têm como função principal orientar o interlocutor em relação ao que o autor deseja que ele imagine. As sentenças de ação orientadora atuam precisamente nesse sentido. No entanto, elas colidem diretamente com o interesse do interlocutor no desenvolvimento das ações.

Eco propôs diferenciar tempo do discurso e tempo de leitura. ${ }^{260}$ Para ele, o tempo do discurso se condicionaria à velocidade das ações desenvolvidas 


\section{Algumas análises}

pelo narrador e/ou pelas personagens. Trata-se, portanto, de uma estratégia de manipulação da linguagem. 0 tempo de leitura seria exatamente o tempo gasto pelo interlocutor para fazer a leitura e a interpretação do texto escrito que ele tem à sua frente. No caso de um diálogo, podemos entender como o tempo que os interlocutores aceitariam ceder de sua atenção para a narrativa que estão ouvindo. 0 conflito entre o tempo do discurso e o tempo de leitura/atenção seria evidente.

Na ficção escrita, com certeza, é difícil estabelecer o tempo do discurso e o tempo de leitura, entretanto, não há dúvida de que às vezes uma grande quantidade de descrição, uma abundância de detalhes mínimos pode não ser tanto um artifício de representação quanto uma estratégia para diminuir a velocidade do tempo de leitura até o leitor entrar no ritmo que o autor julga necessário para a fruição do texto. ${ }^{261}$

Eco trata dos momentos descritivos de uma narrativa. Na medida em que as ações são na maioria das vezes representadas na língua pelos verbos e as imagens por formas nominais, temos que a sequência de verbos e nomes articulados entre si apresentariam maior velocidade de leitura, do que quando há formas que intercalem essa articulação.

Na narrativa que vai no Texto 12 , há momentos de ação rápida, por exemplo, nas sentenças 7 a 12, sobretudo no início:

[...] a cabeça sem corpo saiu em seu caminho, rolando, correndo, jogou-se em cima do homem, seu dente mordia, comeu-o todo. 
As ações vão em sequência, nomes e verbos articulados em frases curtas. Há uma pequena digressão na primeira sentença - "em seu caminho" - e, em seguida, uma sequência de ações. Na sentença, "seu dente mordia", por sua vez, o autor preferiu alongar a ação pela variação de aspecto. Tal como outros casos que já vimos, a interpretação do aspecto cursivo da forma "mordia" será responsabilidade do interlocutor. Essa forma tanto pode se referir a uma ação fixa em que a cabeça sem corpo cerra seus dentes e permanece ali com os dentes cerrados, imóvel durante algum tempo, como pode se referir a uma ação intermitente, numa sequência em que abre e fecha a mandíbula várias vezes. Nesse caso, trata-se de uma ação pontual e dizemos que o verbo é interpretado como télico, que indica uma intenção de realizar uma ação que começa e acaba (ou só começa ou só acaba), ${ }^{262}$ que, no caso, é abrir e fechar a boca fortemente. Se o interlocutor assume que o verbo tem ação pontual, tratando-se de uma forma télica, então seu interpretante será certamente algo como a cabeça sem corpo voando sobre o caçador e dando-lhe mordidas repetidamente, como fosse um ataque de piranhas famintas. Mas, se o interlocutor assume que o verbo tem ação contínua, tratando-se de uma forma atélica, então seu interpretante será uma cabeça sem corpo fixamente grudada no corpo do caçador, imóvel.

A ambiguidade descrita acima se desfaz pela continuação da narrativa que nos informa que o 


\section{Algumas análises}

caçador foi totalmente devorado pela cabeça sem corpo. Note-se que é uma desambiguação retroativa, pois ocorre somente após a formação do interpretante relativo à sentença "seu dente mordia". A interpretação da narrativa, nesse caso, para o leitor que entendeu a forma "mordia" como atélica, deverá perder velocidade, pois ele terá de recompor seus interpretantes, de certa maneira, atrasando, também, o tempo do discurso. No caso de se ter interpretado a forma "mordia" como télica, não haverá mudanças no interpretante e o tempo do discurso não sofrerá atrasos, estabelecendo uma sequência rápida de eventos. Vale a pena ressaltar que, em outras versões dessa narrativa, a cabeça sem corpo se agarra fixamente ao corpo de sua vítima e ali permanece. ${ }^{263}$

A orientação para a composição dos interpretantes que faz o autor de uma narrativa e que, de maneira mais discreta, recebe a ajuda do locutor, atuando em coautoria, não precisa estar necessariamente isolada numa sentença de orientação. Essa orientação pode ser feita durante a própria descrição da ação, como vimos, em que os interpretantes vão se compondo em tempo real, o tempo de leitura de Eco (1994) ou o da atenção que descrevemos mais atrás. A interrupção de uma sequência de sentenças de ação complicadora pela inserção de sentenças de ação orientadora é um recurso viável que, entretanto, corre o risco de, numa enunciação dialógica, perder a atenção dos 
interlocutores e, com isso, o direito de dar continuidade à narrativa.

\section{Texto 13: 0 menino abandonado}

Um menino chorava sempre, na boca da noite.

- Cala a boca, menino! - o pai falava. - Vou te levar para o mato!

Levava o menino e vinha embora. 0 menino vinha embora sozinho.

Um dia, o menino chorava no matão, largado pelo pai, como sempre para aprender a ficar quieto. Aí chegou um Tarupá:

- Vem embora, vamos para casa!

0 pai ficou esperando, na maloca, o menino voltar. Não ouvia mais seu choro:

- O menino calou! - e lembrou:

- Será que o Tarupá carregou meu filho?

Foi atrás, e não encontrou nada, nem choro. Ficaram todos tristíssimos. Desde então, nunca mais alguém abandonou assim uma criança. ${ }^{264}$

\section{Podemos fazer a mesma segmentação que fizemos na narrativa anterior.}

\section{Tabela 7}

1 Um menino chorava sempre, na boca da noite.

2 - Cala a boca, menino! - o pai falava. - Vou te levar para o mato!

3 Levava para o mato e

4 vinha embora.

50 menino vinha embora sozinho.

6 Um dia, o menino chorava no matão,

7 largado pelo pai, como sempre, para aprender a ficar quieto.

8 chegou um Tarupá:

9 - Vem embora, vamos para casa!

10 O pai ficou esperando, na maloca, o menino voltar.

11 Não ouvia mais seu choro: - 0 menino calou!

12 lembrou: - Será que o Tarupá carregou meu filho?

13 Foi atrás 


\section{Algumas análises}

14 não encontrou nada, nem choro.

15 Ficaram todos tristíssimos.

16 nunca mais alguém abandonou assim uma criança.

Bruner considerou que um dos princípios básicos que regeria a construção das narrativas seria o da canonicidade e violação. Ele afirmou que, para se tornar apta a ser contada, uma história precisaria ter um enredo canônico que foi quebrado, violado, ou desviado de maneira a violentar sua legitimidade. ${ }^{265}$ Nesse caso, como vimos acima, a canonicidade é a expectativa presente no senso comum.

A violação da canonicidade dá-se precisamente na relação entre sentenças presas pela mesma juntura temporal. Ainda que a narrativa no Texto 13 não apresente uma abertura como as anteriores, a sentença 1 pode ser tomada como o que Labov (1997) chamou de sentença resumo. Trata-se de uma sentença que apresenta o tema sobre o qual a narrativa vai discorrer. Nessa narrativa, essa sentença resumo acumula a função de ser uma sentença presa, com ação complicadora. Porque ela exprime um evento que tem um caráter negativo, ela, por si só, gera a expectativa de que sentença seguinte venha com a solução para isso. 0 choro infantil é um fenômeno comum, em qualquer sociedade. Via de regra, ele é um aviso de desconforto, um pedido de ajuda. É de se esperar que a solução prevista seja também nesse sentido: "se uma criança estiver chorando, algum adulto deve socorrê-la". No entanto, a sentença 1 
desencadeia uma reação negativa do pai, que lhe promete um castigo na sentença 2. Essa quebra de expectativa tem um certo grau de relatabilidade, pois não era essa a reação esperada. A ira manifesta na sentença 2 provoca a reação descrita nas sentenças 3 e 4, que são a efetivação do castigo. Nesse caso, cumpre-se, parcialmente, o esperado: o pai leva a criança para a mata e volta sozinho. Talvez o castigo fosse exagerado. Deixar crianças sozinhas na mata não parece uma solução adequada, ou, pelo menos, não é coerente com outras narrativas. Ao que parece, nessa relação da causabilidade, o castigo inesperado gera uma expectativa maior. 0 senso comum lembra que coisas horríveis podem acontecer para crianças sozinhas no mato. Mas, na sentença 5, ficamos sabendo que o menino sozinho volta para junto dos pais. Temos aí uma sequência de violações. 0 que temos é de entender se são subsequências sentenciais descritivas ou normativas.

Nas sentenças 6 e 7, recolocamos a criança na mata, mais uma vez castigada pelo pai. Mais uma vez sozinha, à mercê dos perigos que o senso comum conhece. Pela lógica proposta na narrativa, é natural que a criança encontre o caminho de casa. Mas qual! Na sentença 8, ficamos sabendo que um Tarupá chegou onde ele estava. Quem é Tarupá? Tarupás são espíritos maléficos da floresta ${ }^{266}$ que carregam pessoas geralmente para se alimentarem delas. 0 menino foi levado por um desses tarupás. Isso não era do nosso senso comum. Não havia um 


\section{Algumas análises}

interpretante disponível para a palavra "tarupá". 0 turno agora está em risco, porque o locutor se tornou visível novamente. Entretanto, a subsequência 10-15 vem carregada de emoção. Logo na sentença 10, sabemos que o pai se preocupa. Podemos imaginá-lo preocupado, pois o menino não voltou. E agora, pela sentença 11, sabemos que não estava tão longe, pois o pai ouviria o choro de seu filho, se o menino estivesse lá. A expectativa que tínhamos de que o menino voltaria era a mesma do pai, só que o menino não voltou! A relação entre pai e filho, apesar de variar entre sociedades, dificilmente é isenta de emoções, como já salientou Durkheim. Não há a opção de o menino ter se perdido no caminho da volta, o senso comum é claro: não seria razoável pensar que o menino se perderia no mato, pois esse não é o comportamento que se espera dos tuparis, portanto foi um tarupá que o levou, obviamente. E é isso o que vemos na sentença 12. Ora, se foi isso, talvez dê tempo de salvá-lo, pelo menos é o que esperamos que aconteça. E o pai do menino vai atrás dele, na sentença 13. Mas aí já era tarde. A sentença 14 nos faz colocar o pai na mata escura, procurando o filho sem encontrá-lo. 0 menino não estava lá. 0 evento descrito na sentença 15 era previsível, "todos ficaram tristíssimos". Nesse caso, nosso interpretante do pai já está cheio de culpa e de raiva. Isso era óbvio desde o início.

Deixar uma criança sozinha na mata escura não era uma solução adequada, se o menino chorava, pelo 
menos estava por perto, seguro. A sentença 16, chamada de coda, revê isso revelando o caráter perlocucionário da narrativa. 267 Trata-se de um alerta, de uma ameaça. Ainda que possamos imaginar que essa narrativa estabelece um comportamento primordial, ela é também uma narrativa triste que envolve o desaparecimento de crianças. As ações não resultam de heróis civilizadores, mas somente de antepassados. Pode-se, também, entender que o choro do menino seja uma situação inusitada, e pode causar uma reação negativa nos pais. Nesse ponto, é mais um alerta do que uma prescrição. Tanto aos pais quanto aos meninos. Uma das consequências possíveis, mas indesejadas, do choro é a de desencadear a impaciência dos pais e a possibilidade de que tomem uma atitude mais radical decorrente dessa impaciência, como abandonar o filho sozinho no mato. A despeito dos tarupás, a possibilidade de que a narrativa possa ter referência é muito grande. Crianças que choram, pais impacientes, castigos e desaparecimento, nada disso é inverossímil.

\section{Texto 14: Idn Kamni derruba a árvore Ye}

A avô de Idn Kamni mandou-o derrubar a enorme árvore Ye. Idn kamni pintou seu rosto e começou a cortar a árvore Ye. Por dois anos ele cortou a árvore antes que ela começasse a tremer.

Tah! 0 tronco estalou. Glii! Ela inclinou-se para a frente e caiu com barulho. 


\section{Algumas análises}

Então veio uma enchente - como a água subia, todas as pessoas entraram na canoa de Idn Kamni. A água subiu até cobrir os topos das árvores e continuou subindo até que as pessoas tiveram suas cabeças apertadas contra o topo do céu. Então, a água começou a se acalmar. Quando os cimos das árvores apareceram de novo, Idn Kamni disse às pessoas, na canoa, que elas estariam de volta para baixo no mesmo dia.

Depois disso, houve rios neste mundo e seus cursos onde a árvore Ye tinha caído. 0 tronco da árvore Ye é o rio principal e seus galhos os córregos e riachos que correm para ele.

Idn Kamni saiu juntando os galhos finos e as folhas em pilhas que são as corredeiras e as cachoeiras de hoje. ${ }^{268}$

No Texto 14, uma narrativa Maku, grupo do oeste amazônico, há um caráter fortemente descritivo. Trata-se do conto "Idn Kamni derruba a árvore $Y e$ ". Vamos apresentar aqui somente as sentenças de ação complicadora.

\section{Tabela 8}

1

2 jt e

3 começou a cortar a árvore Ye.

Por dois anos

$4 \quad$ ele cortou a árvore

jt antes que ela começasse a tremer.

5 tah! 0 tronco estalou.

6 glii! Ela inclinou-se para a frente

jt e

7 caiu com barulho.

jt Então,

8 veio uma enchente 


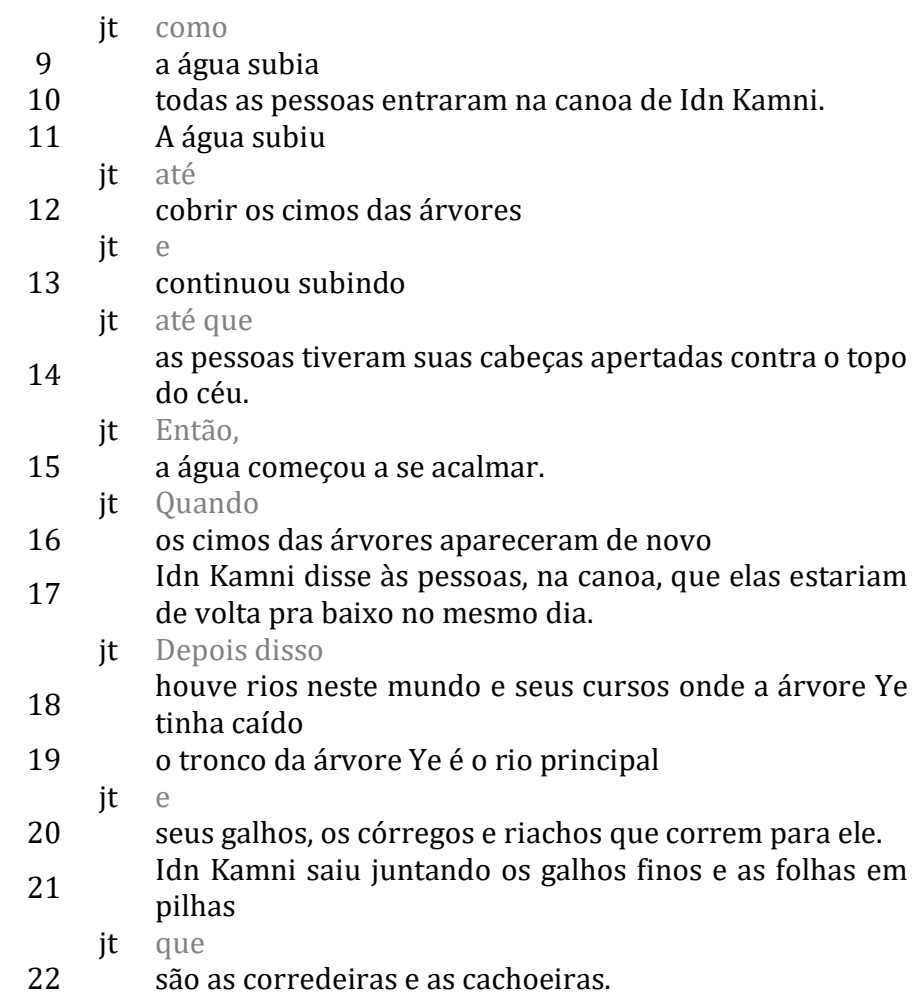

Numa leitura rápida desse conto, temos logo de início a dúvida sobre quem é Idn Kamni, que vai identificado pelo nome próprio. De maneira geral, o narrador pressupõe que ele seja familiar. Logo sabemos que ele tem uma avó, que lhe pede para cortar uma árvore enorme, também chamada pelo nome, que também nos seria familiar. 0 narrador entende que essas informações são partilhadas, que fazem parte do senso comum que nos une a ele. Apesar disso, ele nos ajuda a imaginar a árvore Ye, adjetivando-a como enorme. Com essa imagem, 


\section{Algumas análises}

também somos levados a imaginar as dificuldades que serão enfrentadas por Idn Kamni. A avó quer uma tarefa difícil. $\mathrm{Na}$ sentença 2, somos surpreendidos com uma atitude fora do nosso senso comum, totalmente inesperada. Idn Kamni não foi diretamente realizar sua tarefa; foi pintar seu rosto. Podemos imaginá-lo fazendo isso. Sabemos de antemão que não é uma narrativa cuja trama se desenvolve em nossa sociedade. Apesar de também saírmos de rosto pintado em muitas ocasiões como jogos de futebol, protestos de rua, festas e baladas - não o fazemos para atividades dessa natureza. Mas ele fez e, na sentença 3, ficamos sabendo que ele foi cortar a árvore. Assistimos à realização da tarefa desde o começo. Lá está, como nosso interpretante, Idn Kamni dando machadadas na enorme árvore Ye. Meu interpretante é um machado, mas poderia ser qualquer outro instrumento. Na sentença 4, sabemos que, enfim, ele cortou a árvore. Demorou dois anos, é o que o narrador acrescenta à narrativa. Finalmente a ordem da avó se cumpriu e, na sentença 5, imaginamos os eventos, segundos antes da queda. Uma onomatopeia nos orienta para imaginar isso. $\mathrm{Na}$ sentença 6, a queda efetivamente começa. Também uma onomatopeia nos ajuda na construção desse movimento. Na sentença 7, a queda se finaliza. Foi uma sequência de eventos quase em câmera lenta, fazendo-nos imaginar cada momento da queda. Na sentença 8 , ficamos sabendo que houve uma enchente, mas a relação de causalidade entre a queda da árvore Ye e a enchente parece muito tênue. 
A primeira impressão é que a própria queda da árvore Ye causou a enchente. Ela era enorme. Levou dois anos para ser derrubada. Atualmente podemos imaginar um terremoto seguido de um tsunami, mas a narrativa não faz nenhuma referência a isso.

A reflexão sobre a relação entre a queda da árvore Ye e a enchente não dura muito, pois, na sentença 9, somos levados a imaginar que a água da enchente subia. Trata-se de um verbo com aspecto imperfectivo, de ação inacabada, que cria por si só a expectativa de que a ação vai continuar. Até onde a água vai subir? Na sentença 10 , ficamos sabendo que durante esse processo as pessoas foram salvas por Idn Kamni. Ele tinha uma canoa para isso. Criamos um interpretante com essa informação: é uma canoa com pessoas que vai boiando sobre as águas que iam subindo - é o que vai na sentença 11 . Na sentença 12, podemos imaginar essa canoa de Idn Kamni boiando entre o cimo verde das árvores da floresta, até que desaparecem, porque, na sentença 13 , a informação é a de que a água continuava a subir. Novamente temos a imagem da dúvida: até onde ela pode subir? E a resposta chega logo na sentença 14, que nos faz imaginar que a água pode subir até o céu. E como um acontecimento insólito, somos levados a imaginar as pessoas presas entre a água da enchente e a dureza da abóboda celeste. A abóboda celeste é dura. Sem recursos, as pessoas chegam a bater a cabeça no céu. Mas a bonança vem logo na sentença 15 , que nos faz imaginar que as águas começam a baixar. A enchente cede e segue o caminho inverso. 


\section{Algumas análises}

Se tínhamos imaginado as árvores desaparecendo sob as águas na sentença 12, agora, na sentença 16, podemos inverter, fazendo-as reaparecer. Até que, na sentença 17, Idn Kamni nos acalma a todos, dizendo que em breve, ainda hoje, estaremos a salvo no chão.

Nesse ponto, o narrador nos dá uma série de explicações sobre como interpretar a sequência de eventos que foram narrados. É uma digressão didática que nos faz imaginar o desenho que a queda imprimiu no chão. A imagem que ele nos faz ter como interpretante é a de uma bacia hidrográfica, em que ele associa o tronco da árvore Ye ao rio principal e seus galhos a seus afluentes. Assim, apreendemos que a narrativa era mais uma aula de geografia do que somente a apresentação das peripécias de Idn Kamni. Os interpretantes que fomos levados a criar fizeram-nos ver o mundo num plano cartográfico bidimensional, apesar de ter sido criado por uma narrativa cuja sequência é eminentemente linear, unidimensional.

\section{Texto 15: 0 mito do Sol}

O Sol, antigamente, era um moço forte e bonito. E tinha uma tia que preparava urucu para pintar os tucuna nos dias de festa da Moça-Nova. O Sol era quem partia lenha para a fogueira onde a velha punha para ferver o urucu. A velha era aborrecida e estava sempre pedindo ao Sol mais lenha. O Sol só trazia muirapiranga, porque a tia dele só gostava daquela lenha. Um dia o Sol trouxe muita muirapiranga, muita. E, para acabar com aquele trabalho, pediu à tia que o deixasse 
beber todo o urucu que estava fervendo. A velha, pensando que ele morreria, disse: "Bebe, bebe logo". O Sol bebeu todo o urucu e foi ficando com a cara vermelha como o urucu e a muirapiranga. Depois subiu para o céu e se meteu entre as nuvens. ${ }^{269}$

Se separarmos essa narrativa sentença a sentença, procurando discriminá-las quanto a serem de ação complicadora ou orientadora, teremos:

\section{Tabela 9}

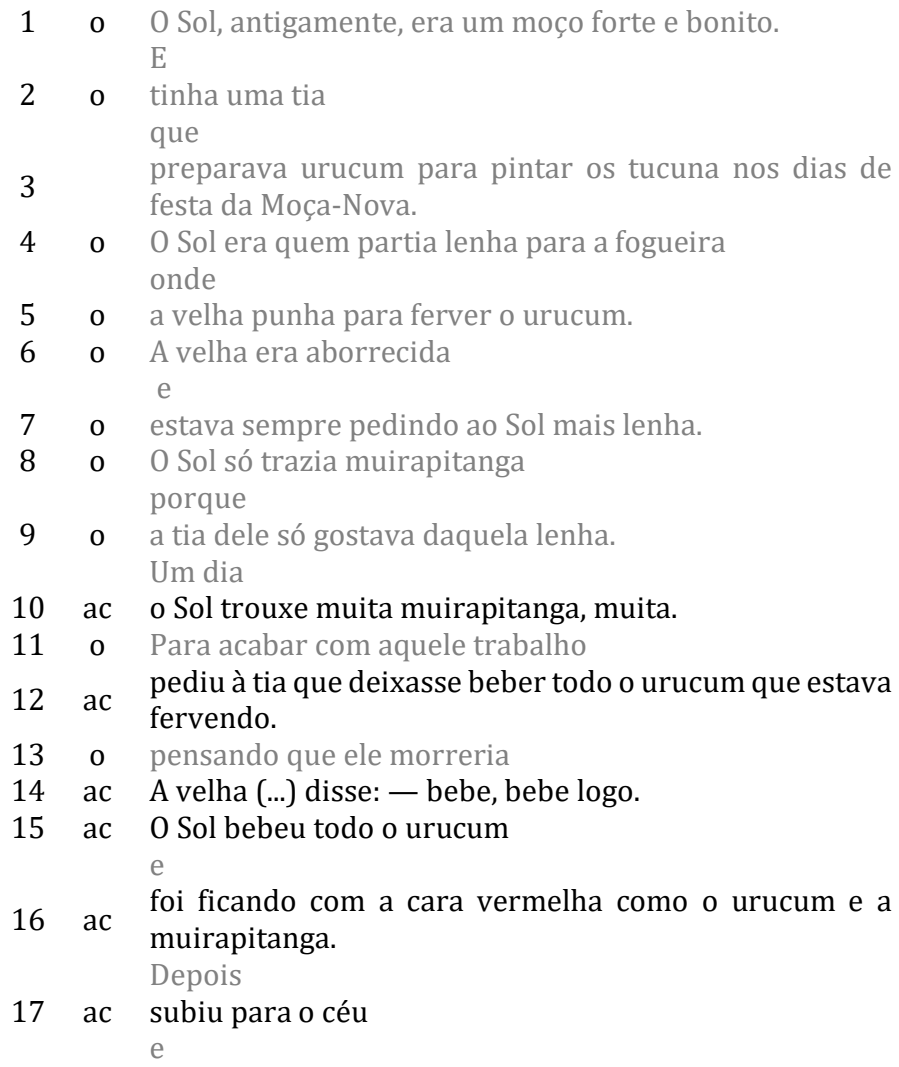

17 ac subiu para o céu e 


\section{Algumas análises}

18 ac se meteu entre as nuvens.

Procurei seguir o critério de um verbo ou de uma perífrase verbal por sentença, ainda que nem sempre isso tenha sido possível ou necessário. Esse é apenas um critério. Poderiam ser definidos outros. Acrescentei a definição de sentença de orientação (o) ou de ação complicadora (ac) logo após a numeração. Como se pode notar, a narrativa faz uma longa introdução orientando o interlocutor quanto ao contexto em que os eventos da narrativa ocorrerão. A narrativa propriamente dita, com suas ações complicadoras, terá seu início somente a partir da sentença 10 .

Podemos notar com facilidade que o autor distribuiu a aspectualização dos verbos de maneira bastante diferenciada nessas duas partes da narrativa. Da sentença 1 até a sentença 9, os verbos estão na forma do imperfectivo - "era", "tinha”, "preparava”, "punha”, "estava”, "trazia”, "gostava” - com exceção de uns poucos que foram usados no infinitivo "pintar", "ferver". Essa opção do autor indica que sua intenção era nos fazer imaginar o cotidiano daquele grupo, em que uns trazem lenha para que outros a usem, como um processo de divisão do trabalho de forma colaborativa, orgânica. Se retomarmos a discussão inicial de Durkheim (1999) e Linton (1981), veremos que se trata de uma sociedade que mantém diferenciação de status, ainda que não sejam suficientes, talvez, para definir uma sociedade 
moderna nos termos em que esse conceito foi proposto.

Na segunda metade da narrativa do Texto 15 , os verbos, em sua maioria, vão na forma perfectiva, especialmente nas sentenças de ação complicadora.

Tabela 10

10 ac o Sol trouxe muita muirapitanga, muita

12 ac pediu à tia que deixasse beber todo o urucum que estava fervendo

14 ac a velha (...) disse: - bebe, bebe logo

15 ac o Sol bebeu todo o urucum

16 ac foi ficando com a cara vermelha como o urucum e a muirapitanga

17 ac subiu para o céu

18 ac se meteu entre as nuvens

Como se pode ver, é uma sequência curta de ações com sentenças longas. A maior quantidade de palavras aumenta o tempo de leitura ou o tempo de atenção do interlocutor, mesmo que o tempo do discurso não sofra nenhuma interferência disso. É importante frisar que o número de palavras usadas se reporta ao Sinn do texto; é um fato eminentemente estilístico. Enquanto o interlocutor estiver atento, as palavras todas terão referências, terão Bedeutung, e, portanto, farão com que o interlocutor mantenha seus interpretantes. Mas, com o alongamento das orientações, elas rapidamente perderão esse efeito orientador e o interlocutor deixará de dar atenção ao locutor ou ao texto, que somente se tornará um barulho incômodo ou rabiscos em uma superfície plana. Todo o valor simbólico da linguagem se perderá. 


\section{Algumas análises}

$\mathrm{Na}$ narrativa do texto Texto 15, temos uma introdução que nos apresenta as personagens que atuarão: o Sol, sua tia, o urucum e a muirapitanga. 0 Sol e sua tia são personificados; o urucum e a muirapitanga, não. Na sentença 1 , o Sol nos é apresentado pelas suas qualidades físicas próprias dos humanos: ser forte e bonito. Intercalada com essa informação, há a definição do tempo em que se passa a história: "antigamente". Imaginamos tratar-se de uma narrativa mítica, sobretudo porque já se conhece o final, isto é, sabemos que o Sol não é mais um moço forte e bonito, mas é tão somente uma bola amarela que está no céu e nos fornece luz e calor. Não sabíamos, entretanto, que ele foi um moço forte e bonito. Além disso, na sentença 2, somos apresentados à segunda personagem humana: a tia do Sol. O Sol tem relações de parentesco com outras personagens, mesmo que o termo "tia" para demonstrar isso não seja uma boa opção. Pelo menos "tia" nos leva a imaginar que se trata de uma personagem mais velha do que o Sol, tendo por isso ascendência sobre ele. Já vimos que, em uma sociedade tradicional, os mais velhos são tratados com deferência, já que são os portadores da tradição. E é justamente o que faz a tia do Sol, como vai descrito nas sentenças 3 e 4 . Era a tia do Sol que dominava a prática tradicional do preparo do urucum usado nas pinturas corporais para os momentos importantes como esse da festa da Moça-Nova. A expressão "festa da Moça-Nova" foi muito feliz, porque é autoexplicativa. Certamente deve referir-se a uma festa de apresentação das 
meninas que se tornaram mulheres e estarão disponíveis para a efetivação de relações conjugais, ou algo assim.

Nas sentenças 4 e 5 ficamos sabendo que o preparo do urucum envolvia fervê-lo e que, para isso, eram, obviamente, necessários lenha e fogo. Apesar de o preparo do urucum ser de responsabilidade da tia, que agora confirmamos ser mais velha, a lenha era responsabilidade do Sol. E, por isso, conforme vai nas sentenças 6 e 7, ele tinha de trabalhar muito, porque a velha tia dele precisava disso, pelo menos pedia o tempo todo. A tia, conforme vai descrito na sentença 9, era seletiva e só gostava de um tipo de lenha, a de muirapitanga, que o Sol, conforme a sentença 8, trazia sempre. Até aqui ficamos sabendo da vida cotidiana dessas personagens, a muirapitanga sendo colhida na mata pelo Sol e usada como lenha por sua velha tia, o urucum sendo fervido, a velha tia preparando a tinta para a festa e o Sol fazendo as vontades da tia.

A narrativa recomeça logo após essa introdução por meio de uma expressão que aponta para isso: "Um dia". Essa expressão tem o mesmo valor da que vimos no Texto 4 "sec hj". A sentença resumo é a sentença 10. Porque descreve uma ação que foge do padrão descrito para as ações cotidianas semelhantes, ela apresenta por si só um grau maior de relatabilidade. 0 Sol sempre trazia lenha, mas, se um dia trouxe mais do que era costumeiro, isso certamente terá um motivo que se espera seja descrito adiante na narrativa. Nossa expectativa 


\section{Algumas análises}

pode ser que ele tenha feito isso porque quis fazer o seu trabalho da melhor maneira possível ou porque sua velha tia exagerou nas suas exigências. $\mathrm{Na}$ sentença 11, o autor nos orienta a interpretar esse evento por um outro ponto de vista. Por se tratar de uma oração intercalada na sentença 12, em que ele pede para beber todo o urucum que estava sendo preparado, somos levados a abandonar a expectativa que tínhamos sobre a intenções do Sol quando trouxe muita lenha, reinterpretando a sentença 10 apenas como descrição. A quantidade excessiva de lenha parece que tem como consequência uma quantidade excessiva de urucum sendo preparado. 0 autor nos apresenta essa relação de forma sutil, por exemplo no uso do quantitativo "todo". Também a oração intercalada atua nesse sentido: "se o Sol beber todo o urucum, o trabalho de trazer lenha estará terminado". Essa lógica interna da narrativa parece que exige informações adicionais. A princípio há 0 estranhamento de beber o urucum que era preparado como tinta, depois a quantidade: bebê-lo todo! Na sentença 13, temos o esclarecimento dessa lógica. Trata-se de uma sentença de ação orientadora que nos leva a crer que a atitude do Sol poderia ser fatal: "quem bebe quantidades excessivas de urucum pode morrer". A narrativa assume, nesse ponto, um caráter um tanto mais dramático, ainda que tenha baixa relatabilidade, pois o Sol ainda existe. Mas somos levados a retomar nossos interpretantes agora atribuindo um desgosto profundo do Sol pela vida que levava 
apenas trazendo lenha para sua velha tia. Tamanho era esse desgosto que preferiu terminar essa sua vida bebendo todo o urucum disponível. Mas também a velha tia agora se nos aparece na sentença 14 definitivamente malvada, pois queria a morte do sobrinho. Não foi apresentado nenhum motivo para esse ódio, ele apenas existia. Na sentença 15, temos o desfecho do desejo do Sol: ele bebeu todo o urucum. Na sentença 16 somos surpreendidos com a transformação do Sol. Não esperávamos que ele morresse, é claro, mas não sabíamos o que aconteceria com ele. Nessa sentença 16, somos levados a imaginar o Sol tomando as cores do urucum e da muirapitanga, que são vermelhos. Novamente o uso do gerúndio nos leva a imaginar um processo em curso e não uma transformação repentina. A transformação foi lenta e culminou, como vai na sentença 17 , na subida do Sol ao céu, para esconder-se entre as nuvens, como vai na sentença 18, que é a final.

Por se tratar de uma narrativa tipicamente mítica, porque apresenta as origens do mundo, não há como ter maior relatabilidade e o próprio evento mais relatável não causa grandes emoções. Ele está nas sentenças 15 a 17, sobretudo na transformação do Sol, na sentença 16. A narrativa, entretanto, apresenta alguns fatos que, talvez, portem mais emoção do que o evento mais relatável. Ao propor que a personagem premeditasse sua morte/transformação para acabar com o sofrimento que lhe era imposto, o autor apresenta a 


\section{Algumas análises}

possibilidade de que, para fugir do desempenho de papéis que conflitem entre si de alguma maneira, tal como propusera Festinger (1975), como vimos mais atrás, atitudes como a do Sol de provocar grandes transformações ou até a própria morte sejam uma opção.

Essa narrativa se apresenta, como já salientamos, o papel duplo, de um lado, de apresentar possíveis consequências de relações conflituosas no desempenho de papéis sociais, além das informações mais corriqueiras como o fato de o urucum e a muirapitanga serem vermelhos, de as mulheres preparem urucum para a pintura corporal, de os homens trazerem a lenha, os sobrinhos prestarem serviço para a velhas tias, de ocorrer pintura corporal na festa da Moça-Nova e de o consumo excessivo do urucum poder ser fatal; de outro lado, de nos entreter com uma narrativa que nos faz conhecer a origem do sol vermelho quando fica entre as nuvens. É de se notar que a estrutura sentencial das ações complicadoras, que são de fato as ações cujo desenvolvimento interessa mais diretamente ao interlocutor, atua exatamente como estratégia para garantir essa atenção.

Labov (1997) chamou a atenção para o fato de que as narrativas que tratem de sexo, morte e humilhações teriam possibilidade maior de obter atenção do interlocutor. 


\section{Texto 16: A mãe das cobras}

A mulher de certo índio cada vez que ia à roça tinha relações sexuais não só com uma cascavel como também com outros ofídios. De uma feita, seu marido foi atrás às escondidas, descobrindo as promiscuidades em que ela vivia com as cobras. Quando deu a luz, nasceram-lhe cobrinhas de todas espécies em grande número. Esses filhotes de cobra separaram-se, enfim, em quatro grupos, dos quais cada um saiu serpenteando numa direção. A última cobrinha que nasceu foi buscar para sua mãe uma tira de envira com a qual esta cingiu o ventre. Depois levou a mulher consigo e esta se transformou em cobra também. 270

Seguindo o exemplo da análise anterior, podemos segmentar a narrativa em suas sentenças de orientação e de ação complicadora.

\section{Tabela 11}

1 ac cada vez que ia à roça

2 ac A mulher de certo índio [...] tinha relações sexuais não só com uma cascavel como também com outros ofídios.

\section{De uma feita}

3 ac seu marido foi atrás, às escondidas

4 ac descobrindo as promiscuidades em que ela vivia com as cobras.

Quando

5 ac deu a luz

6 ac nasceram-lhe cobrinhas de todas espécies em grande número.

7 ac Esse filhotes de cobra separaram-se, enfim, em quatro grupos.

8 ac cada um saiu serpenteando numa direção.

9 ac A última cobrinha que nasceu foi buscar para sua mãe

uma tira de envira

10 ac com a qual cingiu o ventre.

Depois 


\section{Algumas análises}

11 ac levou a mulher consigo

e

12 ac esta se transformou em cobra também.

A primeira sentença da narrativa caracteriza-se pela ação habitual descrita pelo verbo com marca de imperfectivo e pelo distributivo, usado temporalmente nessa sentença, "cada". A forma imperfectiva leva-nos à expectativa de um evento simultâneo que vai logo na sentença 2. Nessa sentença, uma ação complicadora diretamente narrativa apresenta relações sexuais que se realizam entre pessoas e animais, o que, para nosso senso comum, são objeto de grande estranhamento não apenas por serem entre espécies diferentes, mas por serem com cobras. Em que pese sua semelhança com o órgão genital masculino, cobras são venenosas, atacam, podem matar. Nossa expectativa quanto a esse tipo de comportamento apresentado nessa sentença resumo é bastante grande.

Na sentença 3, temos a ação complicadora, com o marido desconfiado das idas de sua mulher à roça. Sua desconfiança vai bem marcada pela expressão "às escondidas". Não há motivo expresso para essa desconfiança, assim somos apenas levados a imaginar um marido desconfiado indo, pé ante pé, atrás de sua esposa. Logo em seguida, como era esperado, somos levados a imaginá-lo, na sentença 4 , entre a folhagem, observando as atitudes de sua esposa. 0 autor nos leva a atribuir a essa 
personagem pensamentos de censura, de julgamento negativo, ao utilizar o termo "promiscuidade". Nosso interpretante desse marido se reconfigura com uma sensação de surpresa indesejada, indignação talvez. Nossa expectativa é a de uma atitude forte dessa personagem, abandonando a esposa, expulsando-a de casa, ou, quiçá, outras mais dramáticas. Mas, nas sentenças 5 e 6, somos levados para um outro lado. Vemos a mulher parindo cobras de espécies variadas. A indignação do marido ficou suspensa por enquanto. Nas sentenças 7 e 8, imaginamos as cobras recém-nascidas se afastando em grupos, quatro grupos, que saem cada qual para um lado. Temos a expectativa de um motivo para esses quatro grupos. Por que quatro grupos? Essa expectativa vai permanecer suspensa também. A informação que nos chega na sentença 9 é que a última cobrinha traz uma tira de envira para sua mãe, que, conforme a sentença 10, usa-a para cingir o ventre. Como há a indicação de que era a última cobra que nasceu, imaginamos o parto já terminado. Deve ter sido longo, pois foram muitas cobras. Cingir o ventre após o parto estabelece a relação "quem pare tem de cingir o ventre com uma corda de envira". $\mathrm{Na}$ sentença 11, a mulher vai embora com sua filha mais nova e, na 12 , ela se transforma numa cobra também.

Embora essa narrativa tenha sentenças com alto grau de relatabilidade, estabelecendo momentos propícios para eventos mais relatáveis, nada disso 


\section{Algumas análises}

acontece. A ação sexual da mulher não foi além dos momentos iniciais da sentença resumo, a indignação do marido foi apenas apresentada e não trouxe nenhuma consequência, a divisão das cobras em quatro grandes grupos não teve qualquer explicação. Nossos interpretantes ficaram apenas disponíveis, mas não foram mais modificados, causando alguma frustração. 0 evento mais relatável ficou restrito à transformação da mulher em cobra. Mas podemos pensar que foi adiantado para o início da narrativa, durante o parto descrito na sentença 4. A sequência das sentenças de ação complicadora apresenta quebras sucessivas em suas relações de causa e consequência, não permitindo que o princípio da canonicidade e violação de Bruner (1991) se estabelecesse. A narrativa se reinicia a todo instante.

Se o conjunto das sentenças de ação complicadora não justifica a narrativa que, por isso, tem, como um todo, grau baixo de relatabilidade, a informação de que maridos desconfiam de esposas que vão à roça, que na roça ocorrem relações sexuais proibidas, que as cobras podem se dividir em quatro grupos, que as mulheres usam uma corda para cingir a barriga após o parto, de certa maneira, cumprem seu papel formativo na enunciação da narrativa.

\section{Texto 17: As relações com o Paí}

Há uma pequena planta, paí-abára=pena de orelha do Paí, cujo caule se divide em dois ramos, cada um dos quais só tem uma única folha avermelhada na ponta. Se alguém se banhar com 
uma infusão de duas dessas folhas, o Paí lhe aparece. Ele toma a figura da esposa ou da amante daquele homem que fez a tentativa. Surge na margem do rio, quando o homem está pescando, e o convida para o coito. Se o homem recusar, o Paí, disfarçado, procura por todos os meios conseguir seu intento. 0 homem, mantendo-se firme, nada pode dizer do acontecido à sua mulher, ao voltar para casa. De um modo ou outro, o Paí depois lhe aparece de novo, ainda na forma de sua amada, tentando todos os meios de sedução; mas o homem deve conservar-se inflexível, e nada dizer. Enquanto, em casa, descansa na sua rede, aparece de novo o Paí em forma feminina, quando a mulher do homem está ocupada, e o desafia com audácia; mas, se o homem não cede, o Paí desaparece logo que sua mulher entra. Caso um homem se deixe seduzir, resulta o mesmo como se tivesse feito, no coito, o papel da mulher: fica grávido, seu ventre incha, e, por não poder parir, morre. Resistindo, porém, a todas as tentações, um dia, durante uma pescaria, aparece-lhe por fim o Paí em figura de homem, louvando-o por sua constância. Ele mesmo pega do remo, senta-se ao leme de sua canoa e manda o homem apanhar o arco e flecha. Rema em direção dos rochedos, e em breve a água fervilha de peixes. 0 homem fisga, a mando do Paí, tantos peixes quantos queira; depois trocam de lugar e o Paí fisga peixes. Então, certo dia, convida o homem para ir à sua casa. Rema com ele para o lugar mais fundo do rio, manda-lhe colocar as mãos nos ombros (do Paí), pula com ele dentro do rio e submerge. Quando o homem, a mando do Paí, abre os olhos, está no seco, no mundo aquático. 0 Paí lhe oferece caxiri e melancias enormes, e ainda lhe dá daquilo para levar. Quando sua mulher em casa lhe perguntar 


\section{Algumas análises}

de onde vieram os frutos, ele não deve responder; se ela suspeitar de relações com o Paí, o homem não deve dar confiança, porque o Paí ouve tudo que se fala dele, e não gosta que se mencione seu nome.

Pessoalmente, Mawaré não conheceu ninguém que tivesse feito a experiência. Disse que hoje ninguém tem mais coragem para tal, desde que um homem tentou o feitiço se deixou seduzir pelo Paí, na crença de que este fosse sua mulher. Seu ventre inchou, ele morreu e foi enterrado. Depois de algum tempo ouviram como o cadáver na cova explodiu com um estrondo surdo. Quando abriram a cova para retirar os ossos, não encontraram nem mais um vestígio do morto. ${ }^{271}$

Se segmentarmos essa narrativa segundo as últimas análises que fizemos, teremos:

\section{Tabela 12}

\begin{tabular}{|c|c|c|}
\hline 1 & 0 & $\begin{array}{l}\text { Há uma pequena planta, paí abara = pena } \\
\text { de orelha de Paí }\end{array}$ \\
\hline 2 & 0 & cujo caule se divide em dois ramos \\
\hline 3 & 0 & $\begin{array}{l}\text { cada um dos quais só tem uma única folha } \\
\text { avermelhada }\end{array}$ \\
\hline 4 & ac & $\begin{array}{l}\text { Se } \\
\text { alguém se banhar com uma infusão de } \\
\text { duas dessas folhas }\end{array}$ \\
\hline 5 & & o Paí lhe aparece. \\
\hline 6 & ac & $\begin{array}{l}\text { Ele toma a figura da esposa ou da amante } \\
\text { daquele homem que fez a tentativa. }\end{array}$ \\
\hline 7 & ac & $\begin{array}{l}\text { Surge na margem do rio } \\
\text { quando }\end{array}$ \\
\hline 8 & ac & o homem está pescando \\
\hline 9 & ac & $\begin{array}{l}\text { o convida para o coito. } \\
\text { Se }\end{array}$ \\
\hline & ac & o homem recusar \\
\hline & ac & $\begin{array}{l}\text { o Paí, disfarçado, procura por todos os } \\
\text { meios conseguir seu intento. }\end{array}$ \\
\hline
\end{tabular}




\begin{tabular}{|c|c|c|}
\hline 12 & ac & mantendo-se firme \\
\hline 13 & o & $\begin{array}{l}0 \text { homem (...) nada pode dizer do } \\
\text { acontecido à sua mulher }\end{array}$ \\
\hline & o & ao voltar para casa \\
\hline & & De um modo ou outro \\
\hline & ac & $\begin{array}{l}\text { o Paí depois lhe aparece de novo ainda na } \\
\text { forma de sua amada }\end{array}$ \\
\hline & ac & $\begin{array}{l}\text { tentando todos os meios de sedução } \\
\text { mas }\end{array}$ \\
\hline 17 & ac & $\begin{array}{l}\text { o homem deve conservar-se inflexível } \\
\text { e }\end{array}$ \\
\hline 18 & o & nada dizer. \\
\hline & o & $\begin{array}{l}\text { Enquanto, em casa, } \\
\text { descansa na sua rede }\end{array}$ \\
\hline & ac & $\begin{array}{l}\text { aparece de novo o Paí em forma feminina } \\
\text { quando }\end{array}$ \\
\hline 1 & o & a mulher do homem está ocupada \\
\hline & ac & $\begin{array}{l}\text { o desafia com audácia } \\
\text { mas }\end{array}$ \\
\hline & & se \\
\hline & ac & o homem não cede \\
\hline 2 & ac & $\begin{array}{l}\text { o Paí desaparece } \\
\text { logo que }\end{array}$ \\
\hline 25 & ac & $\begin{array}{l}\text { sua mulher entra. } \\
\text { Caso }\end{array}$ \\
\hline 26 & ac & um homem se deixe seduzir \\
\hline 7 & ac & $\begin{array}{l}\text { resulta o mesmo como se tivesse feito, no } \\
\text { coito, o papel da mulher: }\end{array}$ \\
\hline & ac & fica grávido \\
\hline 2 & ac & $\begin{array}{l}\text { seu ventre incha } \\
\text { e por }\end{array}$ \\
\hline & o & não poder parir \\
\hline & ac & $\begin{array}{l}\text { morre. } \\
\text { porém }\end{array}$ \\
\hline & ac & $\begin{array}{l}\text { Resistindo (...) a todas as tentações } \\
\text { um dia, durante uma pescaria } \\
\text { por fim }\end{array}$ \\
\hline & ac & aparece-lhe (...) o Paí em figura de homem \\
\hline & ac & louvando-o por sua constância. \\
\hline & ac & Ele mesmo pega do remo \\
\hline & ac & senta-se ao leme de sua canoa \\
\hline
\end{tabular}




\section{Algumas análises}

e manda o homem apanhar o arco e flecha. Rema em direção dos rochedos e, em breve, a água fervilha de peixes.

ac
0 homem fisga a mando do Paí tantos peixes quantos queira depois

$\mathrm{e}$

$\begin{array}{ll}43 & \text { ac } \\ 44 & \text { ac }\end{array}$

\section{Então, certo dia} convida o homem para ir à sua casa.

Rema com ele para o lugar mais fundo do rio

e

manda-lhe colocar as mãos nos ombros (do Paí), pula com ele dentro do rio e

submerge.

\section{Quando}

o homem, a mando do Paí, abre os olhos, está no seco, no mundo aquático.

O Paí lhe oferece caxiri e melancias enormes

\section{e ainda}

lhe dá daquilo para levar.

\section{Quando}

sua mulher em casa lhe perguntar de onde vieram os frutos

ele não deve responder

se

ela suspeitar de relações com o Paí

o homem não deve dar confiança

porque

o Paí ouve tudo que se fala dele e

não gosta que se mencione seu nome.

Pessoalmente, Maraware não conheceu ninguém que tivesse feito a experiência. 


\begin{tabular}{|c|c|c|}
\hline 59 & 0 & $\begin{array}{l}\text { Disse que hoje ninguém tem mais coragem } \\
\text { para tal }\end{array}$ \\
\hline & S & aesale que \\
\hline & & se deixou seduzir pelo Paí \\
\hline 2 & $\mathrm{ac}$ & na crença de que este fosse sua mulher. \\
\hline 63 & ac & Seu ventre inchou \\
\hline 64 & ac & $\begin{array}{l}\text { ele morreu } \\
\mathrm{e}\end{array}$ \\
\hline 5 & ac & $\begin{array}{l}\text { foi enterrado. } \\
\text { Depois de algum tempo }\end{array}$ \\
\hline 66 & $\mathrm{ac}$ & $\begin{array}{l}\text { ouviram } \\
\text { como }\end{array}$ \\
\hline 67 & ac & $\begin{array}{l}\text { o cadáver na cova explodiu com um } \\
\text { estrondo imenso. } \\
\text { Quando }\end{array}$ \\
\hline & ac & abriram a cova para retirar os ossos \\
\hline & $\mathrm{ac}$ & $\begin{array}{l}\text { não encontraram nem mais um vestígio do } \\
\text { morto. }\end{array}$ \\
\hline
\end{tabular}

Trata-se de uma narrativa muito mais longa do que todas as anteriores. Logo no início, o autor faz a descrição de uma planta que ocupa as sentenças de 1 a 3. 0 nome da planta Paí Abara remete a algumas lendas conhecidas em que a figura do Paí aparece. ${ }^{272}$ Não é uma figura que faz parte do senso comum nacional, mas ocorre regionalmente em vários pontos. Esse reconhecimento regional traz, para alguns, um pequeno traço de relatabilidade, na medida em que o Paí Abara já foi associado a algumas outras figuras sobrenaturais cristãs que vão de santos a demônios.

Nas sentenças 4 e 5 , fica estabelecida a relação entre as folhas do Paí Abara e o Paí. Não são sentenças com o verbo no passado, nem perfectivo nem imperfectivo, mas em modo irrealis de uma ação que 


\section{Algumas análises}

não ocorreu. A sentença 4 apresenta a forma verbal infinitiva, atemporal, e a sentença 5 , a forma do presente. É comum que a forma verbal do presente possa indicar também o passado, como já salientou Vargas (2011). No caso em questão, a forma verbal do presente nos leva a um tempo futuro, condicionado pela sentença anterior. 0 aparecimento do Paí será a consequência direta da ação de banhar-se com a infusão das folhas de Paí Abara. A sequência dos eventos vai como proposta de canonicidade, feita pelo próprio autor. Por ter expresso a relação de forma tão detalhada, a pressuposição é a de que o interlocutor não conhece a planta nem as suas propriedades mágicas.

Na sentença 6, há a descrição do comportamento do Paí. Ainda que a forma verbal continue no modo irrealis, de um evento que não aconteceu, a sentença apresenta um evento que dá continuidade lógica ao evento anterior, estabelecendo uma correlação temporal com a ordem das sentenças, isto é, há juntura temporal entre as sentenças, o que confirma o caráter narrativo desse texto. 0 Paí se transforma numa figura feminina desejada sexualmente pelo indivíduo que se banhou na infusão das folhas de Paí Abara. Em seguida, persegue-o na pescaria, como vai nas sentenças 7 e 8 . Ele o procura para relações sexuais, como vai na sentença 9. Pela descrição, o que temos como interpretante é a mulher que, na margem do rio, chama o pescador para o sexo. Sabemos que se trata do Paí, porque vimos isso na sentença 6. Aparentemente imaginamos o Paí como 
figura originalmente masculina, pelo menos é assim que ele vai referido linguisticamente. Mas, até então, não há nenhuma indicação expressa disso.

Na sentença 10, o autor nos apresenta uma sentença de ação complicadora como opção, apontando-nos que a narrativa poderá seguir caminhos diferentes, com duas sequências sentenciais possíveis. 0 primeiro, então, será o da recusa. Nesse caso, temos um pescador rejeitando o convite para o sexo feito pela figura da mulher ao seu lado, que finge ser sua esposa ou amante. A recusa é simples, sem justificativa. Tanto pode ser porque ele já conhece as artimanhas do Paí, como porque aquilo não seria uma prática comum entre ele e sua mulher e, portanto, a negação seria a melhor opção.

O Paí persiste em suas tentativas para convencer o pescador a fazer sexo com ele; é o que vai na sentença 11. Nosso interpretante é, talvez, o de um jogo de sedução, mas um tanto confuso, porque as formas de provocação sexual entre diferentes grupos sociais não são iguais às nossas. Não temos como imaginar isso com facilidade, a não ser apelando para o nosso próprio senso comum, mas isso, certamente, envolveria vestimentas, coreografias, pinturas corporais muito pouco adequadas ao que seria próprio do ambiente descrito na narrativa.

Na sentença 12, a negativa do pescador permanece. De certa maneira, a persistência do pescador em recusar o sexo proposto pelo Paí disfarçado incorre 


\section{Algumas análises}

na definição de uma canonicidade - "se uma esposa ou uma amante oferecer sexo a seu marido ou a seu amante, ele vai aceitar" - que vai violada pela recusa.

Em seguida a essa sequência de eventos, o autor nos alerta para o fato de que se deve manter segredo disso para a mulher, tal como vai expresso na sentença 13. Essa sentença de orientação dirime a dúvida quanto à justificativa da primeira rejeição feita pelo pescador que foi suscitada na sentença 10: o pescador sabia que se tratava de uma artimanha do Paí para conquistá-lo. Essa revelação feita nas entrelinhas pelo autor nos leva a uma nova canonicidade, talvez uma especialização da anterior - "se uma figura feminina oferecer sexo a um homem, ele vai aceitar" —, e, novamente, a violação é a recusa. Nossa expectativa, bem como a do Paí, era a de que o homem aceitaria a oferta de ter relações sexuais com uma figura feminina. Mas isso não ocorreu. E assim a narrativa continua numa sequência de ofertas e rejeições. Nas sentenças 15 e 16, novamente o Paí aparece convidando o moço para o sexo; na sentença 17, o moço rejeita de novo; nas sentenças 20 e 22, o Paí aparece novamente, longe dos olhos da esposa, como vai na sentença 21 , e, na sentença, 23, o moço rejeita a proposta mais uma vez. 0 jogo de sedução é constante e vai manifesto nas sentenças $9,11,15,16,20$ e 22.0 autor usa das expressões "convida para o coito", "procura por todos os meios conseguir seu intento", "tentando todos os meios de sedução" e, finalmente, 
"desafia com audácia". A partir dessas quatro tentativas crescentes em intensidade - podemos até imaginar que o desafio com audácia beire o sexo explícito - que faz o autor para estimular nossa imaginação quanto ao jogo de sedução do Paí, ele termina esse caminho proposto para essa parte da narrativa.

A sentença 26 dá início a outra sequência de eventos, dessa vez desencadeada pelo aceite do convite ao sexo feito pelo Paí disfarçado. $\mathrm{Na}$ sentença 27, ficamos sabendo que, ao aceitar o convite, o homem toma o papel da mulher na relação sexual em que se envolve. Não fica muito claro isso, pois não há indicação de que o Paí tome a forma masculina e o homem tome a forma feminina, ou se o sexo se faz como na relação entre dois homens ou ainda alguma outra possibilidade que não conseguimos rever. 0 fato é que é o homem que recebe a inseminação e engravida, tal como vai nas sentenças 28 e 29 . Na sentença 30 , ficamos sabendo que ele não pode parir, o que nos faz rever nosso interpretante gerado no ato sexual descrito na sentença 27 - o homem não dispõe de órgão genital feminino, logo a relação não deve ter sido como a de homem e mulher, mas como a de dois homens. Por não dispor do mecanismo fisiológico adequado para o parto, o homem morrerá, como vai descrito na sentença 31, que finaliza esse caminho.

Nesse ponto, o autor retoma a primeira sequência de eventos, dando-lhe continuidade. Na sentença 32 é que ocorre essa retomada. Logo em seguida, na 


\section{Algumas análises}

sentença 33, o autor nos leva de volta à imagem do Paí, dessa vez sem disfarce. Ficamos sabendo que o Paí é homem, e não uma figura sobrenatural assexuada que pode se disfarçar de mulher, isto é, a figura masculina não será um disfarce, mas uma figura que faz parte de sua própria natureza.

Na sentença 24, temos uma avaliação positiva do comportamento do homem que resistiu a todo assédio que lhe foi feito. Trata-se de um reforço ao que vimos como canonicidade em relação a isso. Isso nos leva a crer que o autor pressupõe que faz parte da natureza do homem aceitar esse convite ao sexo, caracterizando-se, portanto, como status atribuído, e, por isso mesmo, sua recusa ao sexo seria decorrente da realização do papel de um status adquirido.

Por ser de natureza masculina, o Paí tem atividades próprias desse status. Nas sentenças 35, 36 e 38, ele assume o controle do barco, do comportamento do pescador e dos próprios peixes, tal como vai nas sentenças 37 e 39 . Por ser uma figura sobrenatural, tem poderes igualmente sobrenaturais, capazes de tornar a vida muito mais fácil, tal como vai na sentença 40. Em seguida, nas sentenças 41 e 42, ele novamente assume seu status masculino e desempenha o papel previsto.

A sentença 43 retoma as atividades do Paí, agora amigo do pescador. Nosso interpretante, depois de imaginar uma pescaria agitada, é a de que são dois iguais que novamente saem para uma caça ou 
pescaria... 0 convite do Paí é para irem à casa dele, como está na sentença 43. Eles seguem pelo rio, de barco, como na sentença 44. Nosso interpretante envolve as mesmas imagens que já tínhamos. Apenas nas sentenças 45 e 46 é que ocorre alguma mudança, pois, depois de irem ao lugar mais fundo do rio, na sentença 44 , saltam para dentro dele. $\mathrm{Na}$ sentença 45, o autor nos faz pensar que o Paí tem cuidado com o homem para que ele não se perca e, então, possa se afogar. É um reforço para a relação de amizade que já imaginamos desde a sentença 43.

Nas sentenças 46 e 47, o Paí leva o homem para o rio, no ponto mais fundo que imaginamos. Já sabemos de seu caráter sobrenatural que provocava o homem para ter relações sexuais com ele, transformando-se em figura feminina. Sabemos também que, devido às posições inflexíveis do homem, o Paí desistiu das provocações e estabeleceu uma relação de amizade com ele. Ao levar o homem para o fundo do rio, essa condição dúbia do Paí, que poderia querer levá-lo consigo para as profundezas com intenções distintas daquelas da amizade, cria um certo grau de relatabilidade. 0 senso comum, de maneira geral, entende que as profundezas da terra, dos mares e dos rios são habitadas por seres cujas intenções não são sempre as melhores. Nas profundezas estão os mortos enterrados ou os mortos afogados. A relatabilidade está justamente em descobrir por que alguém quereria ir para lá. 


\section{Algumas análises}

Na sentença 48, ainda sob o comando do Paí, o homem abre os olhos e, na 49, descobrimos que está "no seco, no mundo aquático". Como esse mundo ainda nos era desconhecido, mas possibilitado pela intertextualidade de outras narrativas de ficção, como no livro Viagem ao Centro da Terra, de Júlio Verne, ou na animação "Bob Esponja Calça Quadrada", de Stephen Hillenburg. No entanto, é bem possível que, desprovida dessas imagens prévias, a revelação de um mundo seco sob as águas possa ser surpreendente. Nesse mundo seco, há o mesmo que o homem dispunha na aldeia, mas com as facilidades próprias das coisas sobrenaturais, é 0 que vemos nas sentenças 50 e 51 .

0 homem retorna à casa, mas não sabemos de sua viagem, apenas o imaginamos levando melancia à sua mulher na sentença 52. Em que pese a curiosidade da mulher, ela deverá permanecer alheia às atividades dele com o Paí, conforme as sentenças 52 a 55. Faz parte da natureza do Paí existir às escondidas, mas onisciente. É o que vai nas sentenças 56 e 57.

0 Texto 17 insere uma nova narrativa, que trata do mesmo tema. Mantivemos a numeração das sentenças. Ela tem uma introdução em que o narrador a apresenta como um relato de um terceiro que, por sua vez, faz o mesmo, como seria na expressão "um amigo de um amigo meu". Essa expressão cumpre a função de o narrador, pretensamente autor da narrativa, eliminar-se como 
testemunha do fato, literalmente incrível, que vai ser descrito. Assim, com essa responsabilidade transferida para um anônimo, feita nas sentenças 58 e 59, a narrativa tem sua primeira sentença, a resumo, contando-nos que houve um homem que tentou o feitiço, o que nos faz retomar a narrativa anterior, em que um homem se banharia numa infusão de folhas de Paí Abara e se encontraria com o Paí. É o que vai na sentença 60. Em seguida, imaginamos, porque ele nos conta isso na sentença 61, que o homem fez sexo com o Paí, tomando-o por seu disfarce de mulher, como vai na sentença 62 . Como já sabemos que o disfarce do Paí servia apenas como estratégia de sedução, não temos dificuldade em imaginar a sequência dos eventos e, como tal, as sentenças 63 e 64 nos mostram isso: ele engravida e morre.

Embora a expectativa fosse que essa segunda narrativa terminasse com a morte do homem grávido, pois foi até aí que a narrativa anterior nos fez imaginar, já há alguma surpresa quando ocorre a sentença 65, que descreve o óbvio que é ele ter sido enterrado. A sentença 66 , auxiliada por uma juntura temporal lexicalizada, gera uma nova expectativa, que é a de todos ouvirem algo. 0 que gerou o barulho estrondoso e surdo, da sentença 67, foi a explosão do cadáver enterrado. 0 que nos faz imaginar que a barriga do homem grávido cresce ininterruptamente e, sem conseguir parir, explode. Parece que essa imagem foi compartilhada pelas 


\section{Algumas análises}

personagens, pelo menos é o que o autor nos faz imaginar na sentença 68, em que, para surpresa de todos, ao desenterrarem o corpo para retirar os ossos, não encontram nada ali, como vai na sentença 69 , que finaliza a narrativa.

Essa segunda narrativa atua como se fosse uma ilustração da proposta teórica feita na narrativa principal. Seus verbos vão nas formas do passado e seu evento mais relatável, certamente, é a explosão inusitada do cadáver, que ocorre no final. A narrativa principal, com verbos na forma do presente, apresenta duas sequências de eventos condicionadas à escolha de um comportamento específico do herói. Ela não apresenta relatabilidade acentuada nas sequências sentenciais possíveis. Entretanto, dado que as práticas mágicas para a conquista realizadas pelo Paí envolvem exclusivamente a provocação sexual, a relatabilidade dessa narrativa decorre diretamente desse fato. Os interpretantes estimulados pelo autor tendem a desenvolver-se no sentido daquilo que faz os próprios interlocutores excitarem-se, ainda que, talvez por interferência do locutor, em coautoria, a narrativa não tenha explorado esse aspecto, como se poderia esperar.

O desempenho do papel masculino vai apresentado tanto pelo que seria sua forma hipoteticamente não marcada, isto é, o homem naturalmente se deixa seduzir pela figura feminina, como pela forma hipoteticamente marcada, isto é, condicionada pela sociedade que estabelece que, ao desempenhar o 
papel de status masculino, não se pode deixar seduzir por qualquer figura feminina que se encontre. Esse tipo de restrição ao comportamento sexual masculino pressupõe um conflito a ser resolvido na ocasião em que houver esse desejo. Nesse caso, podemos entender que a comparação entre o evento real e o descrito na narrativa poderá atuar como as profecias autorrealizáveis de Merton e, portanto, fazer com que o indivíduo possa imaginar as consequências futuras das opções comportamentais disponíveis naquele momento.

\section{Texto 18: Popoca}

Um homem, noutros tempos, foi pescar e levou consigo sua mulher.

E querendo pescar noutro lugar, onde havia mais peixes, deixou a mulher ao pé da Serra do Maiari, sentada numa pedra.

Quando o homem já estava longe e entretido em apanhar peixes, apareceu Popoca.

Saltou sobre a mulher, uniu seu corpo ao dela. Depois, pondo-a nos ombros, seguiu pelo mesmo caminho por onde tinha ido o pescador.

O homem já vinha de volta e se encontrou com Popoca.

- Por que vais levando minha mulher: Eu sou o marido dela. Larga-a.

E Popoca, continuando a andar, disse ao pescador:

— Cala a boca, senão eu te flecho!

E o pescador só levava debaixo do braço um covo. Nem arco, nem flechas.

E Popoca era uma fera, que tinha muita força e muita astúcia. 


\title{
Algumas análises
}

0 pescador viu Popoca afastar-se, rindo e cantando.

\author{
Airêrê rarê raruia \\ Iuançará imã \\ Mapaga
}

Em seguida estrangulou a mulher e lhe jogou o cadáver num lago perto de Cantã. E continuou a rir e a cantar.

\author{
Airêrê rarê raruia \\ Iuançará imã \\ Mapaga 273
}

Se fizermos a segmentação das sentenças, teremos a Tabela 16 que vai a seguir:

\section{Tabela 13}

\section{Noutros tempos}

1 ac um homem (...) foi pescar

2 ac levou consigo sua mulher.

$\mathrm{E}$

3 ac querendo pescar noutro lugar

$4 \quad$ o onde havia mais peixes

5 ac deixou sua mulher ao pé do Maiari sentada numa pedra. Quando

6 o o homem já estava longe

7 o entretido em apanhar peixes

8 ac apareceu Popoca.

9 ac Saltou sobre a mulher

10 ac uniu seu corpo ao dela.

Depois

11 ac pondo-a nos ombros

12 ac seguiu pelo mesmo caminho por onde tinha ido o

13 ac O homem já vinha de volta

14 ac se encontrou com Popoca. 
15 ac - Porque vais levando minha mulher? Eu sou marido $\mathrm{E}$

16 ac continuando a andar

17 ac Popoca (...) disse ao pescador: - Cala a boca, senão te flecho.

$\mathrm{E}$

18 o o pescador só levava debaixo do braço um covo. Nem arco nem flecha.

E

19 o Popoca era uma fera

que

20 o tinha muita força e muita astúcia.

21 ac 0 pescador viu Popoca afastar-se

22 ac rindo

23 ac cantando: Airêrê rarê raruia/Iuançará imã/Mapaga E, em seguida,

24 ac estrangulou a mulher e

25 ac lhe jogou o cadáver num lago perto de Cantã. $\mathrm{E}$

26 ac continuou a rir

27 ac cantar: Airêrê rarê raruia/Iuançará imã/Mapaga

A narrativa que vai no Texto 18 tem seu início pela descrição de uma situação corriqueira, própria das atividades que se realizam em sociedades tradicionais. As sentenças 1 e 2 fazem-nos imaginar isso. A sentença 3 apresenta uma ação complicadora cujo verbo em forma aspectual cursiva cria por si só uma expectativa de que outro evento ocorreria simultaneamente. A justificativa para a mudança no sentido dos eventos vai justificada pela sentença de orientação 4, o que aumenta a expectativa que foi estimulada pelo verbo no gerúndio. A dúvida quanto à sequência de eventos descrita decorre de seu 


\section{Algumas análises}

detalhamento excessivo: por que o homem não foi pescar diretamente no lugar onde ele sabia que havia mais peixes? A expectativa aqui foi gerada principalmente pelo excesso de informações. Trata-se de uma consequência do que Grice chamou de "máxima da quantidade". Segundo o autor, o excesso de informações "pode ter um efeito indireto, na medida em que os ouvintes podem ser levados ao engano, ao inferir que há algum objetivo particular no fornecimento de informações". ${ }^{274}$ Nesse caso, o que seria tratado como um problema de comunicação se tornou uma estratégia para manutenção de relatabilidade. Na sentença 5, a ação complicadora é o homem deixar sua mulher sozinha. Essa é uma violação de várias canonicidades possíveis: "Se o marido leva a mulher à pescaria, ele não a deixa para ir pescar sozinho", "uma mudança de planos numa pescaria que se faz acompanhado envolve todos os que vão junto", "não se deixa uma pessoa indefesa sozinha na mata", etc. Apesar dessas canonicidades inobservadas, o pescador seguiu seu caminho solitário, como é o nosso interpretante estimulado pelas sentenças 6 e 7. Essas sentenças articulam-se com as anteriores por uma juntura temporal lexicalizada. A aspectualização, com um caráter inceptivo, ${ }^{275}$ vai marcada antes mesmo do início da sentença, nesse caso acentuando que o evento tinha sido iniciado, o que vai reforçado pelo advérbio "já" e pela forma verbal perfectiva.

Com base nos interpretantes que temos desencadeados pelas sentenças de ação complicadora 5 e 6 , 
há um cenário propício para que grandes problemas possam ocorrer. Trata-se de uma sequência sentencial com um grau de relatabilidade bem maior do que as demais. A sentença 8 cumpre a função de apresentar uma figura que vai referida por seu nome próprio. $\mathrm{O}$ autor entende que essa informação seja comum a seus interlocutores, pois não há detalhamento da personagem Popoca. Faz parte do senso comum seu reconhecimento.

Ainda que não haja detalhamento sobre o Popoca, a sentença 9 nos dá informações suficientes sobre seu caráter. A sentença 10 completa a ação anterior. Trata-se de uma cena de estupro que vai modalizada, talvez pela interferência do locutor atuando em coautoria, pela expressão "uniu seu corpo ao dela". A atenuação da violência, nesse caso, promove uma quebra da expectativa gerada pelas sentenças 5 e 6 . Nossos interpretantes se confundem entre eventos sobrenaturais, como seria, por exemplo, a apropriação de almas por seres malignos da floresta e a união carnal das figuras que imaginamos. A dúvida é, pelo menos parcialmente, desfeita pelas sentenças 11 e 12, que descrevem o Popoca levando embora a mulher como fosse um fardo pesado que se carrega sobre os ombros. Não há muita dúvida de que se trata de um momento bastante dramático, que impõe ao interlocutor, no papel de leitor-modelo, imaginar uma cena de violência desmedida.

Nas sentenças 13 e 14, imaginamos a cena do homem vendo sua mulher sendo levada no ombro 


\section{Algumas análises}

pelo Popoca. Ele se revolta e fala para que a deixe ali mesmo, como vai na sentença 15 . 0 verbo final na fala do marido está na forma do imperativo. Imaginamos tratar-se de uma ameaça. Ao que parece, pelo menos somos levados a imaginar isso pelas sentenças 16 e 17, também o Popoca entende a fala do marido dessa maneira. No entanto, a ameaça não surte nenhum efeito, e o Popoca segue seu rumo e ainda lhe devolve outra ameaça.

Logo em seguida, as sentenças de orientação nos fazem imaginar uma cena de grande frustração e impotência. Se o encontro entre Popoca e o homem tinha apresentado alguma expectativa de confronto entre ambos, ela se desfez numa sensação desagradável de contrariedade, injustiça e impunidade. Resta-nos imaginar o homem, vendo a imagem de Popoca carregando sua mulher, afastar-se vitorioso, como vai nas sentenças 21 a 23, e, num golpe ainda mais dramático e decisivo, descrito na sentença 24, estrangular a mulher e depois atirar seu corpo inerte, como se faria com qualquer resto de comida que se vai dispensar. É o que está na sentença 25.0 estupro seguido de morte vai recompensado pela felicidade do estuprador como consequência da ação impensada do marido ao deixar sua esposa sozinha na floresta e ainda ao andar desarmado, como ficou descrito na sentença 18.

A narrativa que vai no Texto 18 tem um formato típico daquilo que chamamos atualmente de imprensa marrom, que denuncia cenas de violência 
e de impunidade apresentando os eventos quase sempre do ponto de vista das vítimas. Trata-se de uma estratégia cultural de apresentar mecanismos de defesa contra a maldade que faria parte da natureza do mundo: "não se deve deixar mulheres indefesas sozinhas", "não se deve sair desarmado", dentre outras possibilidades não expressas na narrativa. As maldades do mundo, entretanto, não se questionam. Elas, parece que existem por si sós. As entidades maléficas das matas são fortes e poderosas e, por isso, são impunes. Mulheres serem estupradas na floresta seria uma consequência dessa existência. Ao se encontrar um corpo feminino morto e violentado nas matas, certamente isso se justificaria pelo senso comum: foi o Popoca! Ou outro qualquer dessa natureza. A narrativa, portanto, mais que denunciar os perigos da floresta, apresenta justificativa para esses perigos, eliminando, assim, que a suspeita do estupro seguido de morte caia sobre outros que não sejam seres malignos da floresta.

\section{Texto 19: 0 homem e a filha}

Era uma vez um casal que teve uma filha. A mulher morreu pouco depois do parto e a criança foi criada pelo pai. Quando a menina cresceu, o pai anunciou-lhe:

- Minha filha, quero casar contigo! Mas a menina respondeu:

- Isso não é bom. Seremos descobertos pelos outros, pois no mundo não há segredos!

- Sempre quero ver se no mundo não há segredos, disse o pai. 


\section{Algumas análises}

Foi buscar arroz, vazou duas medidas numa panela e cozinhou-o. Em seguida, levou a panela para o mato e enterrou-a. Ninguém sabia que ele tinha enterrado no mato uma panela cheia de arroz a não ser ele próprio e a filha. Tempos mais tarde, apareceram homens com redes para caçar no mato. Eles não sabiam que no local onde caçavam, debaixo de uma árvore, estava enterrada uma panela cheia de arroz. Descobriram, admirados, que formigas brancas saídas da terra junto daquela árvore, transportavam grão de arroz. De imediato cavaram o buraco e encontraram uma panela cheia de arroz cozido. A filha, então, voltou-se para o pai:

— Está a ver papá? Eu não lhe disse que o mundo não tem segredos?! 276

Se segmentarmos esse texto, conforme já fizemos anteriormente, teremos:

\section{Tabela 14}

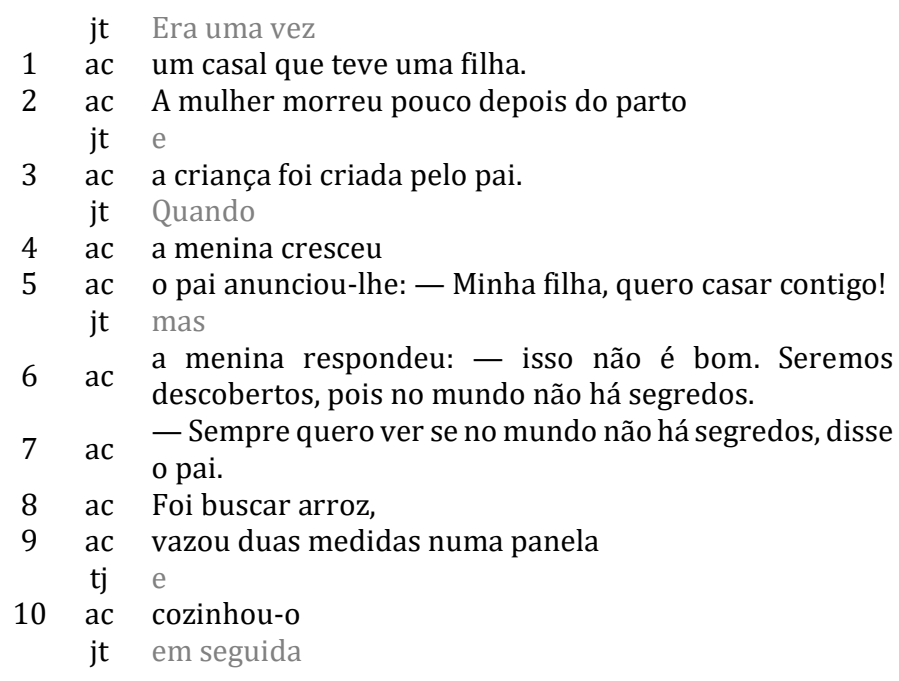


11 ac levou a panela para o mato

jt e

12 ac enterrou-a.

13 o Ninguém sabia que ele tinha enterrado no mato uma panela cheia de arroz a não ele próprio e a filha.

jt Tempos mais tarde

14 ac apareceram homens com redes para caçar no mato.

15 o Eles não sabiam que no local onde caçavam estava enterrada uma panela cheia e arroz.

Descobriram, admirados, que formigas brancas saídas

16 ac da terra junto daquela árvore transportavam grãos de arroz.

jt De imediato,

17 ac cavaram o buraco

jt e

18 ac encontraram uma panela cheia de arroz cozido.

jt Então

19 ac A filha (...) voltou-se para o pai: - Está a ver, papá? Eu não lhe disse que no mundo não tem segredos.

A narrativa que vai no Texto 19 inicia com expressão que aponta para o seu próprio desenvolvimento. A sentença 1 é a sentença resumo que atua como ponto de partida para a ação complicadora disposta na sentença 2 . Era de se esperar que o nascimento de um filho fosse seguido de manifestações de alegria, mas nossa expectativa se quebra com a informação da morte da mãe. Por ser, a princípio, um evento dramático, uma vez que a morte não é bem-vinda, sobretudo quando se trata de mãe de crianças pequenas, a possibilidade de sermos estimulados para gerar interpretantes carregados com emoção de tristeza é bastante forte. Entretanto, esse estímulo se desfaz logo, na sentença 3 , seguinte, pelo aumento da velocidade no tempo do discurso em descompasso com a velocidade do tempo de leitura, isto é, muitos anos se passam na narrativa 


\section{Algumas análises}

enquanto temos apenas uma juntura temporal. Essa estratégia bloqueia o estímulo das emoções de tristeza que seriam gerados pelas sentenças 1 e 2, porque somos levados a imaginar uma filha já crescida na sentença 4, devidamente criada pelo pai. Essa informação, dada na sentença 3, leva-nos a imaginar que o status de pai nessa sociedade envolve a responsabilidade da criação dos filhos, no caso da ausência da mãe. Da mesma maneira, essa informação também nos leva a tomar o status materno como o responsável principal pela criação dos filhos.

A expectativa de uma sequência de eventos guiada pelo senso comum das canonicidades brunerianas vai violada pela fala do pai da menina, agora crescida, ao anunciar que pretende casar-se com ela. De imediato, nosso senso comum é pego de sobressalto porque esse tipo de relação entre pai e filha é tratado como incestuoso e é fortemente reprimido pelo senso comum e pela ação legal do Estado. A narrativa ganha uma relatabilidade altíssima nesse ponto em que a violação da canonicidade é anunciada como um dos próximos eventos possíveis. De certa maneira, nossa expectativa vai para a solução que o autor dará para resolver tamanho conflito que nos foi criado ao ter estimulado a criação desse interpretante. Como já dissemos anteriormente, a condição de leitor-modelo nos faz acrescentar novas crenças às já existentes em nosso senso comum; não as substitui. Estamos, portanto, inseridos na condição 
que Festinger chamou de dissonância cognitiva, em que crenças conflitantes coexistem cognitivamente e nos levam a envidar esforços para resolvê-las. No entanto, numa narrativa, ao atuarmos como leitor-modelo, estamos nos sujeitando ao controle do autor dessa narrativa. Será sua responsabilidade desfazer o conflito criado.

A solução para o conflito ocorre logo em seguida, na sentença 6. Somos levados a entender que, apesar de não manifestar desacordo com a proposta de seu pai, a menina chama a atenção para o fato de que essa proposta não seria socialmente bem aceita, o que resolve nosso conflito pela semelhança da avaliação. Por não negar a proposta paterna, mas reencaminhá-la numa direção inesperada, somos estimulados a revisar o interpretante da menina para tomá-la como uma personagem inteligente e perspicaz.

Logo na sentença 7 , temos a consequência da reformulação do interpretante da menina, o pai tem a sua atenção voltada para outra preocupação, eliminando a questão do casamento incestuoso da narrativa.

$\mathrm{Na}$ sentença 8, a narrativa toma outro rumo, apresentando uma nova sentença resumo. Uma pequena sequência sentencial que descreve eventos próprios de uma ação cotidiana, da sentença 8 à 10 , culmina em sentenças de ação complicadora. $\mathrm{Na}$ sentença 11, quebra-se a expectativa da sequência estabelecida pelas sentenças de 8 a 10 . A 


\section{Algumas análises}

canonicidade envolve o fato de que "quem faz arroz come o arroz que fez". No entanto, o pai leva o arroz para o mato, na sentença 11, gerando a expectativa de que ele comeria seu arroz naquele local. A violação dessa canonicidade vem com a informação de que a panela de arroz cozida foi enterrada, como está na sentença 12. Ninguém comeu o arroz. E tudo foi feito em segredo, como nos orienta a sentença 13.

A narrativa tem, então, outro recomeço. Esse recomeço vai marcado por uma juntura temporal que faz o tempo do discurso correr mais rapidamente do que o tempo de leitura, outra vez. Uma nova sentença resumo nos apresenta os fatos iniciais, na sentença 14. A sentença de ação complicadora 16 já nos adianta o resultado final do teste empreendido pelo pai da menina. De fato, pouca coisa poderia ocorrer depois da descoberta que os caçadores fazem. As sentenças 17 e 18 terminam a ação esperada sem apresentar nenhuma violação. A sentença 19, final, que normalmente seria dispensável, faz o fecho retomando o interpretante que já tínhamos da menina.

De maneira geral, a narrativa do Texto 19 ocorre em sentido contrário ao que poderíamos esperar em termos de evento mais relatável, pois o ponto de maior relatabilidade ocorre logo no início. As sentenças restantes ficam muito aquém disso, tornando a sequência dos eventos pouco atrativa. As informações secundárias, tais como o fato de se caçar com rede, de se observarem formigas brancas, de crianças serem criadas somente pelo pai, além da 
inusitada proposição de um casamento incestuoso e da perspicácia da menina que, sem discordar do pai, evita uma sequência desastrosa, continuam, como nas demais narrativas, sendo prolíficas.

\section{Texto 20: Os segredos da nossa casa}

Certo dia, uma mulher estava na cozinha e, ao atiçar a fogueira, deixou cair cinza em cima do seu cão. 0 cão queixou-se:

- A senhora, por favor, não me queime! Ela ficou muito espantada: um cão a falar! Até parecia mentira... Assustada, resolveu bater-lhe com o pau com que mexia a comida. Mas o pau também falou:

-0 cão não me fez mal. Não quero bater-lhe! A senhora já não sabia o que fazer e resolveu contar às vizinhas o que se tinha passado com o cão e o pau. Mas, quando ia sair de casa a porta, com um ar zangado, avisou-a:

—Não saias daqui e pensa no que aconteceu. Os segredos da nossa casa não devem ser espalhados pelos vizinhos. A senhora percebeu o conselho da porta. Pensou que tudo começara porque tratara mal o seu cão. Então, pediu-lhe desculpa e repartiu o almoço com ele. 277

\section{Tabela 15}

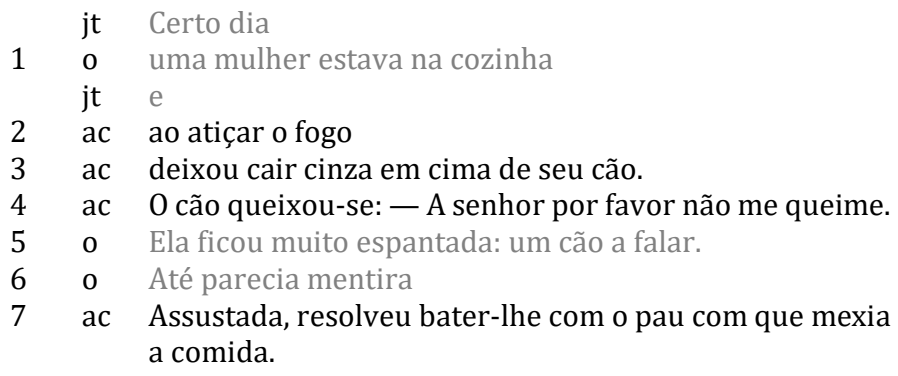




\section{Algumas análises}

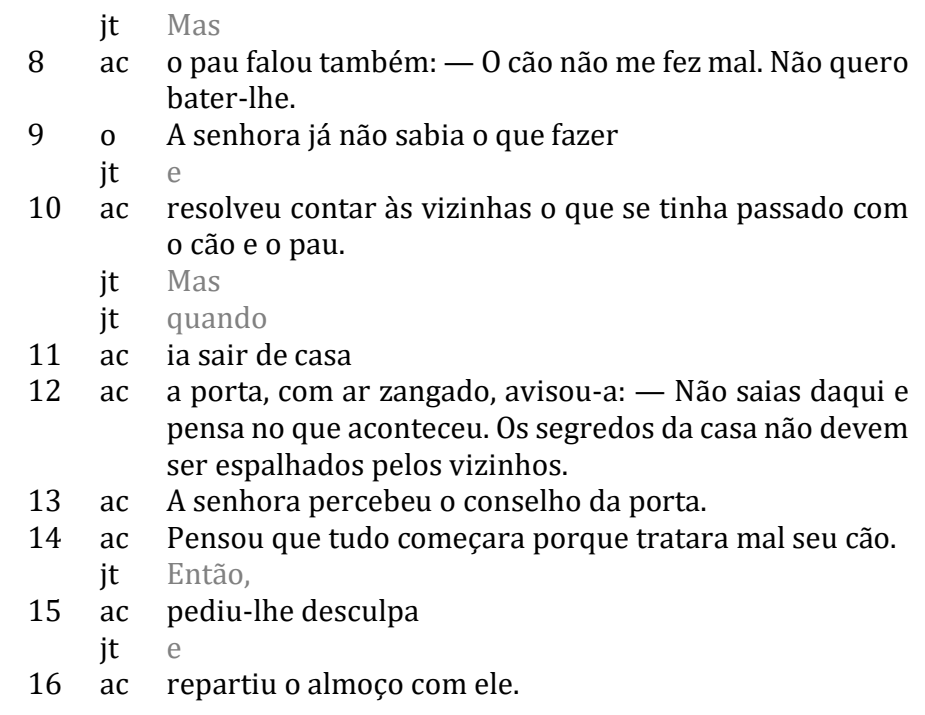

0 início da narrativa do Texto 20 segue o padrão de se estabelecer um momento qualquer para seu desenvolvimento. Esse tipo de início, tal como já vimos, tanto pode mostrar para o interlocutor ou para o leitor-modelo que a seguir vai ocorrer uma narrativa e que, portanto, ele deverá assumir sua posição; como para mostrar que os eventos que serão descritos inserem-se em um contexto temporal indeterminado, mas que não faz parte de um passado imediato em que as testemunhas estejam necessariamente presentes.

A sentença resumo 1 descreve uma situação cotidiana de um ambiente urbano, ou quase isso. A separação de uma habitação em cômodos funcionais é própria da cultura ocidental. A sentença 2 mantém o caráter cotidiano das práticas desenvolvidas nas 
cozinhas, embora caracterizem-se como fatos que talvez tenham ocorrido em ambiente bastante diverso. A sentença 2 é de ação complicadora porque gera uma situação que não era esperada, ainda que possa ser considerada possível. A situação cotidiana se quebra na sentença de ação complicadora 4, quando, numa atitude fora dos padrões, o cachorro fala. A propriedade de animais falarem em narrativas não fere sua verossimilhança, na medida em que as intenções atribuídas a eles são as mesmas que se atribuiriam a humanos falantes. 0 que traz um aumento da relatabilidade, da expectativa, é a própria surpresa atribuída à personagem humana, que vai nas sentenças 5 e 6 . A reação da mulher, na ação complicadora 7, provoca um certo desconforto pois pressupõe que a atitude inesperada do cachorro deva ser penalizada com violência, o que nos impinge aceitar como senso comum uma regra como "se um cachorro fala e reclama, ele deve ser penalizado com violência". É uma regra que, dificilmente, poderia ser aceita no senso comum, pelo menos de parte da sociedade ocidental. Trata-se, obviamente, de uma tentativa de eliminar o que foge à tradição o mais prontamente possível. A censura a esse comportamento ocorre na sentença 8, em que, tal como o cachorro, o pau de mexer comida fala com intenções igualmente humanas. A sentença 9 descreve somente o estado de espírito da personagem, decorrente da surpresa de ter encontrado objetos e animais falantes em sua casa. A sentença 10 tem ação complicadora com expectativa de nível mínimo, mas ainda tem alguma, 


\section{Algumas análises}

pois gera curiosidade sobre as opiniões possíveis de outras personagens, pela divulgação dos fatos recém-descobertos pela heroína. No entanto, a sentença 12 quebra essa expectativa com a fala de mais um objeto animado que, adiantando-se às interpretações possíveis do leitor-modelo, estabelece um princípio comportamental de maneira explícita a ser seguido naquela situação e em situações semelhantes. A sequência das sentenças 13 e 14 descreve a mudança de comportamento gerada pelos eventos anteriores. As sentenças 15 e 16 atuam especificamente no sentido de demonstrar que, de fato, essa mudança de comportamento se efetivou em novas práticas cotidianas, finalizando a narrativa.

Trata-se de uma narrativa que não estabelece grande expectativa, ou seja, tem baixa relatabilidade sobretudo por não apresentar um evento mais relatável que não seja senão o de a heroína se conformar com uma mudança no desempenho de seu papel. No entanto, no que diz respeito ao tratamento dado aos animais, a narrativa apresenta uma reflexão importante sobre a conduta social. Como já dissemos, a intolerância com a diferença, que foi descrita na sentença 7 e censurada na sentença 8, parece fazer parte do cotidiano da sociedade para a qual a narrativa foi elaborada. Por ser um comportamento comum a várias sociedades, a narrativa tem um traço de universalidade bem maior do que o esperado. De maneira semelhante, a prática da divulgação de eventos particulares, que 
vai descrita na sentença 10 e censurada na 12 , também parece fazer parte do cotidiano daquela sociedade. A censura, por sua vez, tem um caráter bastante ambíguo. Podemos, ao assumir o papel de leitor-modelo, entender que se trata de fazer com que a heroína evite ser tratada com escárnio, na medida em que cães, paus de mexer comida e portas falantes não existem. Podemos também entender que a censura decorre do estímulo à privacidade, que, possivelmente, não era preconizada pela heroína. Também, nessas interpretações, é possível encontrar traços universalizantes em relação ao desempenho do papel referente ao status de mulher. Nessa narrativa fica pressuposto que o comportamento feminino é intolerante e fofoqueiro e que deve ser modificado de maneira que as mulheres passem a ser tolerantes e discretas. Ainda que tais valores possam ser tomados de forma positiva, sobretudo a tolerância com a diferença, a proposição de se fazer a mudança no desempenho exclusivamente para o status de mulher, estimulado por um narrador assexuado, implica uma diferença entre status masculino e feminino bastante óbvia naquela sociedade.

\footnotetext{
Texto 21: Como a língua sobreviveu aos dentes

(Liu Hsiang)

Chang Chuang estava doente e Laotse veio visitá-lo. Este disse a Chang Chuang: - estás muito doente. Não tens nada que dizer ao teu discípulo?
} 


\section{Algumas análises}

- Ainda que não me perguntasses, eu ia dizer-te - replicou Chang - sabes por que uma pessoa não deve descer do carro quando chega à aldeia? - Não significa este costume que as pessoas não devem esquecer sua terra de origem? - replicou Laotse.

- Ah, sim... Mas deixe-me perguntar outra coisa: sabes por que uma pessoa deve correr ao passar debaixo de uma árvore alta?

- Não significa que se deve respeitar os mais velhos? disse Laotse.

- Ah, sim... então Chang Chuang escancarou a boca e mostrou sua língua para Laotse, pedindo que ele olhasse bem lá dentro, dizendo: o que você vê agora?

- Sua língua, mestre - disse Laotse.

- Meus dentes estão aí? - disse o velho.

- Não - replicou Laotse.

- E sabes por quê? - perguntou Chang Chuang?

- Não durou a língua mais tempo por ser flexível? E não caíram os dentes por serem mais duros? - retorquiu Laotse.

- Ah, sim... disse Chang Chuang - acabas de aprender o Tao. Não tenho mais nada para te ensinar. 278

\section{Tabela 16}

1 o Chang Chuang estava muito doente

jr e

2 ac Laotse veio visitá-lo.

3 ac Este disse a Chang Chuang: - estás muito doente. Não tens nada que dizer ao teu discípulo?

- Ainda que não me perguntasses, eu ia dizer-te -

4 ac replicou Chang -- sabes por que uma pessoa não deve descer do carro quando chega à aldeia?

5 ac - Não significa este costume que as pessoas não devem esquecer sua terra de origem? - replicou Laotse. 
- Ah, sim... Mas deixe-me perguntar outra coisa; sabes

6 ac por que uma pessoa deve correr ao passar debaixo de uma árvore alta?

7 ac - Não significa que se deve respeitar os mais velhos? disse Laotse.

8 ac - Ah, sim...

jt então

9 ac Chang Chuang escancarou a boca jt e

10 ac mostrou sua língua para Laotse

11 ac pedindo que ele olhasse bem lá dentro

12 ac dizendo: o que você vê agora?

13 ac - Sua língua, mestre - disse Laotse

14 ac - Meus dentes estão aí? - disse o velho.

15 ac — Não - replicou Laotse.

— Não durou a língua mais tempo por ser flexível? E não

16 ac caíram os dentes por serem mais duros? - retorquiu Laotse.

17 ac - Ah, sim... disse Chang Chuang - acabas de aprender o Tao. Não tenho mais nada para te ensinar.

A narrativa que vai no Texto 21 caracteriza-se pela predominância do discurso direto em relação ao indireto. Podemos definir que sentenças que portem eventos descritos por discurso direto sejam necessariamente tomadas como de ação complicadora. São eventos que têm de se manifestar temporalmente, por exigirem um momento específico para sua realização, que envolve, necessariamente, a ação de falar. No entanto, conforme já vimos anteriormente, 279 não há necessidade de se fazer tratamento diferenciado dessas formas de discurso. A representação da fala, entretanto, tem de ser tomada como parte de uma unidade sentencial maior do que ela. Trata-se, pois, de uma instância narrativa, no contexto de outra instância. É uma prática comum narrarem-se 


\section{Algumas análises}

histórias dentro de histórias. Exemplo clássicos disso como o Pañcatantra ${ }^{280}$ e o Livro das mil e uma noites, ${ }^{281}$ o Decamerão, ${ }^{282}$ dentre muitos outros, abusaram dessa técnica. 0 conjunto das narrativas do Pañcatantra envolve grande quantidade de instâncias narrativas, que mantêm seus eventos mais relatáveis em suspenso, para serem retomados gradativamente depois. Trata-se de uma estratégia que deixa o interlocutor tomado pela expectativa quanto ao curso dos eventos narrados. Saliente-se que, nesses casos, a personagem tratada com discurso direto torna-se narrador, em discurso indireto, de outra narrativa, o que, de certa forma, consolida a proposta de Genette (1971) que já discutimos. Podemos lembrar que, no Livro das mil e uma noites, a heroína Šahrāzad, para evitar sua própria morte a ainda salvar futuras noivas de seu marido, que matava suas mulheres após a primeira noite de núpcias, faz para ele narrativas entremeadas de narrativas, sem finalizá-las. Dessa maneira, por preterir o evento mais relatável de cada uma de suas narrativas, Šahrāzad consegue a atenção de seu algoz, que opta por mantê-la viva para poder descobrir o final da história que ela própria contava.

A narrativa que vai no Texto 21 tem seu início pela sentença de orientação que descreve a situação de saúde de uma das personagens. 0 verbo vai usado na forma imperfectiva, o que confere uma maior relatabilidade à sentença em que se insere porque pressupõe que outro evento seria descrito em 
concomitância. 0 evento descrito na sentença 2 satisfaz a expectativa da sentença 1 . As sentenças 3 e 4, já em discurso direto, apresentam uma situação de diálogo na forma de pergunta e resposta encenado pelas próprias personagens. Esse padrão se repete nos pares sentenciais seguintes 6 e 7. A opção pelo diálogo nesse tipo de texto, notadamente instrucional, é uma prática que se repete em várias sociedades. ${ }^{283} \mathrm{~A}$ confirmação da resposta ocorre na sentença 8, encerrando esse pequeno diálogo. Nas sentenças seguintes, de 9 a 11, segue um conjunto de eventos em que uma das personagens apenas se prepara para os eventos que serão descritos pelas sentenças 12 a 17, que constituem uma terceira parte do diálogo. Novamente, há pares adjacentes entre as sentenças 12 e 13, 14 e 15, 16 e 17. Esse diálogo entre as personagens vai ao encontro do princípio discutido em Santos (1994), em que as perguntas feitas pelo mestre, cujas respostas já são dele conhecidas, conduzem o pensamento do discípulo na direção adequada. No diálogo em questão, são diversas metáforas que têm de ser decodificadas pelo discípulo, por meio da indução promovida. Nessa última parte, de que constam três pares adjacentes, é possível pressupormos tratar-se da sequência mais complexa e de decodificação mais difícil. A dificuldade vai expressa na própria quantidade de perguntas necessárias para isso. Saliente-se que uma pergunta tem por si só maior relatabilidade do que uma asserção, porque deixa o interlocutor em suspenso até que uma resposta seja oferecida, finalizando um par adjacente de pergunta 


\section{Algumas análises}

e resposta. Por ter um caráter muito mais instrucional do que de entretenimento, a narrativa do Texto 21 apresenta relatabilidade baixa. 0 evento mais relatável decorre de uma sequência de perguntas que apenas conduzem o raciocínio para a decodificação final, como a última peça de um quebra-cabeças.

\section{Texto 22: É bom não ter cabeça}

(Do "Luyichi", século IX)

No tempo de Han Wuti (140-87 A. C.), Chia Yung de Ts'angwu servia como magistrado em Yüchang. Um dia saiu para dar combate a bandidos. Foi ferido e teve a cabeça decepada. Mesmo assim, o corpo montou a cavalo e voltou ao campo. Os soldados, e o povo que ali estava, ficaram admirados e Yung falou pelo peito - "Fui derrotado pelos bandidos e eles me cortaram a cabeça. Digam-me francamente se é melhor ter cabeça ou ficar sem cabeça?" Os homens lamentaram-no e disseram - "É melhor ter cabeça". E Yung replicou - "Não penso assim. Andar sem cabeça também é bom". 284

\section{Tabela 17}

jt $\quad$ No tempo de Hau Wuti (140-187 a.C.

1 o Chia Yung de Ts'anguw servia como magistrado em Yüchang

jt Um dia

2 ac saiu para dar combate a bandidos.

3 ac Foi ferido

jt e

4 ac teve a cabeça decepada.

jt Mesmo assim

5 ac o corpos montou a cavalo

jt e 
6 ac voltou ao campo.

7 ac os soldados e o povo que ali estavam ficaram admirados jt e

Yung falou pelo peito: "Fui derrotado pelos bandidos e

8 ac eles me cortaram a cabeça. Digam-me francamente se é melhor ter cabeça ou ficar sem cabeça."

9 o Os homens lamentaram-se

jr e

10 ac disseram: "É melhor ter cabeça."

11 ac Yung replicou: "Não penso assim. Andar sem cabeça também é bom."

A narrativa do Texto 22 inicia caracterizando o momento histórico em que se encerrariam os eventos que serão narrados. A sentença 1 , por sua vez, orienta o leitor-modelo para a criação da personagem. Uma primeira expectativa é gerada por meio da juntura temporal "Um dia", que, tal como já vimos nas demais narrativas, marca efetivamente que a sentença a seguir já contenha alguma ação complicadora. De fato, a expectativa se completa, porque na sentença 2 temos a informação de que o herói saiu para combater bandidos. A simples presença de bandidos, como já vimos na narrativa do Texto 4: Vindo da casa da pitanga (Lukas), é suficiente para aumentar a relatabilidade da sentença. Novamente, a expectativa se completa pela informação da sentença 3 de que o herói foi ferido. Ainda que o intervalo entre as sentenças conte com uma juntura temporal lexicalizada, o tempo de leitura é rápido e a ação complicadora vem logo na sentença 4, o que, de certa maneira, dá compatibilidade com o tempo do discurso, igualmente rápido. A expectativa gerada pela 


\section{Algumas análises}

descrição do evento da sentença 4, que seria a morte do herói, é quebrada pela sentença 5 , em que temos a informação de que o corpo monta a cavalo. Até a sentença 4, teríamos o interpretante de nosso herói caído, ou em movimento de queda, sem sua cabeça. A informação da sentença 5 nos faz reformular essa imagem, colocando um corpo sem cabeça sobre um cavalo e, na sentença 6 , indo de volta ao campo. A juntura temporal "Mesmo assim" quebra um pouco da surpresa que é saber que o herói não morreu, mas apenas teve a cabeça decepada. A credibilidade ele define como:

A credibilidade de uma narrativa é a extensão em que os ouvintes acreditam que os eventos descritos tenham ocorrido de fato na forma descrita pelo narrador. 285

Um corpo vivo, andando sem cabeça, montando a cavalo, numa narrativa que se pretende histórica, tal como se anunciou nas suas primeiras sentenças, teria uma credibilidade muito baixa, se é que teria alguma. 0 nonsense dessa sequência de eventos traz à tona o que Labov (1997) chamou de Paradoxo da Relatabilidade. Labov definiu esse paradoxo como a seguir:

A relatabilidade é inversamente proporcional à credibilidade. ${ }^{286}$

Esse paradoxo estabelece um princípio de limites de credibilidade, isto é, até que ponto um evento que desafie o senso comum consegue ser aceito pelo leitor-modelo. 0 senso comum entende que as 
pessoas sem cabeça estão mortas. Se não estiverem mortas, seja como uma cabeça sem corpo, seja um corpo sem cabeça, isso se seguirá da lógica própria da narrativa que restabeleceria a credibilidade dos eventos. Assim como podem ocorrer animais falantes, objetos animados e mulas-sem-cabeçaque-soltam-fogo-pelas-ventas, também um corpo sem cabeça pode receber intenções humanas e ser tratado como personagem de narrativa de ficção. Nesse caso, há uma retomada do interpretante inicial, o próprio herói Chia Yung, que será reformulado como figura não humana de aparência humana. A transformação é retroativa e corre o risco de perder a credibilidade e, com ela, a atenção do leitor-modelo.

Na sentença 6, temos a informação de que nosso herói sem cabeça voltou ao campo. Talvez alguma ambiguidade na expressão "campo" interfira na construção do interpretante, uma vez que ficamos em dúvida se é o campo de batalha ou outro campo qualquer. A sentença 7 não resolve a ambiguidade, pois nos informa que, no campo, estavam soldados e povo. No entanto, recoloca-nos a expectativa do nonsense da situação, pois também as personagens que veem nosso herói se surpreendem com sua condição. A sentença 8 nos informa que o herói sem cabeça fala com eles pelo peito, fazendo-nos, ainda outra vez, reformular o interpretante que tínhamos, para colocar uma boca em seu peito. Uma vez que, como já vimos em outra narrativa, as crenças $a d$ hoc 


\section{Algumas análises}

que temos de aceitar como leitor-modelo acrescentam-se às antigas, a nova figura do herói compara-se com a do Mapinguari amazônico. ${ }^{287}$ Ainda nessa mesma sentença, inicia-se uma sequência de diálogo em ordem direta em que a personagem questiona seus interlocutores sobre a vantagem ou a desvantagem de se não ter cabeça. Apesar de, na sentença 10, seus interlocutores assumirem que é desvantagem, o herói, na sentença 11, que é a final, descreve sua situação como boa.

De maneira geral, a narrativa apresenta uma sequência que levaria a um evento mais relatável, dado o paradoxo da relatabilidade crescente que ocorre a partir da sentença 5. No entanto, podemos pensar que o pico da relatabilidade em relação a esse evento ocorre na sentença 7 , quando soldados e povo observam-no. Parece ter havido uma queda abrupta da relatabilidade quando, na sentença 8 , a própria fala do herói toma um rumo distinto do que seria esperado, isto é, das ações de guerra e de vingança, para um questionamento de sua situação pessoal. A narrativa parece ser apenas um fragmento de outra maior, cuja continuidade poderia ser o estímulo à vingança sem medo de mutilações violentas ou coisas que tais. Embora não tenhamos nenhuma informação sobre isso, não seria surpreendente se essa continuação ocorresse. 


\section{Texto 23: Aviso de mãe}

Samara acorda de manhã com um telefonema de seus amigos chamando-a para acampar. Ela muito animada diz que sim e vai correndo até a mãe contar a notícia. Sua mãe, muito preocupada, diz;

- Minha filha, não vá a esse acampamento, pois estou com um pressentimento ruim.

A filha rindo, disse:

- Que nada, bobagem. Eu vou sim.

A mãe, para não acabar com a animação da filha, diz;

- Então me deixe ir com você, assim ficarei mais tranquila.

A menina continua insistindo e diz:

- 0 carro já está cheio, não cabe mais ninguém, juro mesmo.

No dia do passeio... Os seus amigos chegam e Samara vai ao carro, e sendo interrompida por sua mãe, com ar de tristeza, dizendo;

- Vai com Deus, minha filha querida.

Samara, com ar de deboche, exclama:

- Só se ele for no porta-malas.

Assim todos os seus amigos riram. E a mãe ficou triste com a reação da filha. No caminho, acontece um acidente e o carro capota por um penhasco. Infelizmente, todas as pessoas do carro faleceram. Mas, por mais incrível que pareça, o porta-malas do carro não sofreu nenhum arranhão sequer, ficou intacto. ${ }^{288}$

\section{Tabela 18}

1 ac Samara acorda de manhã com um telefonema de seus amigos chamando-a para acampar.

2 ac Ela, muito animada, diz que sim

jr e

3 ac vai correndo até a mãe contar a notícia. 


\section{Algumas análises}

Sua mãe, muito preocupada, diz: — minha filha, não vá a

4 ac esse acampamento, pois estou com um pressentimento ruim.

5 ac A filha rindo disse: - Que bobagem, mãe. Eu vou sim.

6 ac A mãe, para não acabar com a animação da filha, diz: -

7 ac A menina continua insistindo jt e

8 ac diz: - 0 carro já está cheio, não cabe mais ninguém, juro mesmo.

jt No dia do passeio,

9 ac os seus amigos chegam

jt e

10 ac Samara vai no carro

jt e

11 ac sendo interrompida por sua mãe,

12 ac com ar de tristeza, dizendo: - Vai com Deus, minha filha querida.

13 ac Samara, com ar de deboche, exclama: - Só se for no porta-malas.

jt Assim

14 ac todos seus amigos riram

15 ac e a mãe ficou triste com a reação da filha.

jt No caminho

16 ac acontece um acidente

jt e

17 ac o carro capota por um penhasco.

jt Infelizmente

18 ac todas as pessoas do carro faleceram.

jt Mas,

jt por mais incrível que pareça

19 ac o porta-malas do carro não sofre nenhum arranhão

20 o ficou intacto.

A narrativa que vai no Texto 23 tem seu início com a criação de um contexto explicativo de fundo para o desenvolvimento dos eventos que virão descritos a seguir. 0 nome próprio da personagem caracteriza 
seu gênero feminino e vai reiterado pelas marcas morfológicas que ocorrem. Os nomes próprios têm a propriedade de especificar uma unidade num conjunto de unidades semelhantes anônimas. Dessa maneira, ele individualiza a personagem e coopta o leitor-modelo para a criação de um interpretante familiar a ambos os interlocutores. 0 convite feito por amigos para um acampamento da sentença 1 , rapidamente complementado por sua aceitação alegre na sentença 2 , nos leva a um interpretante de uma moça jovem alegre com amigos. A imagem da juventude da personagem vai reforçada pela sentença 3, que nos informa que ela foi levar essa informação à sua mãe. A inserção de uma segunda personagem feminina, adulta, estabelece que ambas, apesar de compartilharem do status de mulher, têm participação social diferente. A moça, por correr à mãe, pode ser caracterizada como solteira, o que nos faz reformular nosso interpretante como uma moça jovem alegre solteira que tem amigos com os quais pratica atividades de lazer conjuntas.

A sentença 4, que envolve tanto a caracterização subjetiva de mulher que ostenta o status mãe, feita pelo narrador, como a sua própria expressão, feita pela personagem, nos faz imaginar uma personagem amargurada que teme o sofrimento da filha: ela tem pressentimento ruins. Essa descrição do desempenho referente ao status de mãe vai ao encontro do que já vimos no Texto 1: Ser Mãe, em que o narrador, ao descrever esse status, mostra que ele 


\section{Algumas análises}

envolve uma série de sofrimentos que decorrerão naturalmente da maternidade. Assim, a maternidade envolveria um poder natural de adiantar-se aos acontecimentos de maneira a ser capaz de salvaguardar a prole de perigos futuros. A narrativa que está no Texto 23 corrobora de forma intensa para essa caracterização do status mãe.

Na sentença 5, assumindo seu status de moça alegre jovem solteira e com amigos, o evento descrito caracteriza o conflito de crenças entre as gerações. De maneira geral, como já vimos anteriormente, um dos fatos que caracteriza a mudança de uma sociedade tradicional para uma sociedade moderna é exatamente o fato de que a transmissão de conhecimento deixa de ser feita entre as gerações para ser feita pelos pares, criando diferenças entre as gerações. Nessa sentença 5, essa diferença entre as crenças da mãe e da filha vai bem marcada pelo uso da expressão "bobagem" feito pela filha, questionando a capacidade de previsão de perigos que faria parte da natureza do status de mãe. A sentença 6 descreve um outro discurso direto da mãe que se propõe a viajar junto da filha e dos amigos. Verdadeiro nonsense no contexto da narrativa, a proposição envolve mais uma vez a ideia de que o status de mãe é por sua própria natureza capaz de proteger a prole indefesa de quaisquer perigos. Nas sentenças 7 e 8 , também no formato do discurso direto, a moça jovem alegre e solteira retoma sua relação com a mãe, fazendo-nos 
reconfigurar seu interpretante, agora tomado por uma certa hipocrisia, por tentar arranjar desculpas plausíveis para a negação.

Após uma juntura temporal lexicalizada que aponta para uma mudança no tempo do discurso, as sentenças 9 e 10 descrevem cenas adequadas para criarmos um interpretante de saída de viagem. Esses eventos culminam nas sentenças 11 e 12, descrevendo a despedida da mãe, ainda com o mesmo interpretante de preocupada com seus pressentimentos ruins, desejando à filha boa sorte, mas valendo-se de uma expressão de caráter religioso. A sentença 13 descreve comportamento da filha semelhante àquele da sentença 5 . As falas da personagem Samara descrevem uma pessoa cujo status é jovem alegre solteira e com amigos no contexto de uma sociedade moderna. A sentença 14 mostra que os amigos participam dessa mesma condição por compartilharem, por meio de descrição de que todos entenderam, pelo mesmo ponto de vista, o comentário feito pela Samara em relação à expressão usada por sua mãe. A sentença 15 apenas opõe os traços de ambos os status, mostrando que há uma mudança em curso, na medida em que as expectativas da mãe e da filha são diferentes quanto aos pressentimentos maternais.

Após mais uma juntura temporal, há o cumprimento da expectativa em relação aos pressentimentos ruins da mãe. Na sentença 16 , descreve-se a 


\section{Algumas análises}

ocorrência de um acidente e, na sentença 17, há a informação de que todos morreram, inclusive a Samara. É de se esperar que seja o evento mais relatável porque envolve o evento mais dramático descrito na narrativa. Lembramos que a morte, sobretudo de jovens alegres, solteiros, nunca é bem-vinda. A sentença 19, no entanto, precedida por uma série de junturas temporais lexicalizadas que, pela antecipação dos vínculos de estados emocionais, atenuam o impacto do evento que virão a seguir, traz uma nova informação a respeito do porta-malas do carro, que não sofreu nenhum dano. Essa informação tem como propósito fazer-nos associar esse evento com a fala da personagem Samara descrita na sentença 13 , isto é, qualquer um que fosse no porta-malas teria ficado protegido, o que corrobora a lógica da narrativa que faz parte da natureza do status de mãe essa propriedade sobrenatural de proteção de seus entes queridos, tanto filhos como deuses.

Essa narrativa caracteriza com muita clareza um processo de mudança social, que se faz do ponto de vista da sociedade tradicional, tratando-se, portanto, de um ponto de vista reacionário. Não se tome aqui a palavra "reacionário" como algo necessariamente negativo, mas tão somente como um ponto de vista de um autor/narrador que rejeita a mudança que descreve. Porque nem sempre toda mudança é boa, nem sempre é ruim, haverá variedades de interpretações na sua avaliação como 
evento de uma narrativa. Nessa narrativa, a avaliação fica evidenciada pela morte da personagem jovem alegre solteira e com amigos. Caso a narrativa não descrevesse algum acidente e Samara voltasse viva de seu passeio, a avaliação negativa cairia sobre as "crendices" maternas.

\section{Texto 24: A moedinha de cinquenta centavos e o repelente eletrônico}

Algum tempo atrás, eu estava tomando banho num finalzinho de tarde. Estava sozinha em casa, e quando digo sozinha, é porque não havia outra pessoa comigo, com exceção, é claro, dos gatos e dos cachorros... Então, no meio do banho, eu senti que caiu uma moedinha de cinquenta centavos na minha cabeça. Isso mesmo sei lá. 289

Tabela 19

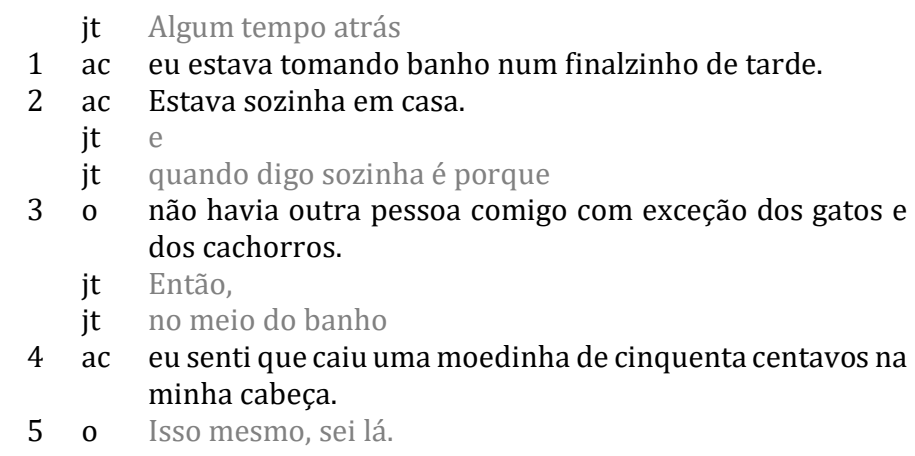

A narrativa que vai no Texto 24 inicia-se por uma expressão que marca um momento na história do narrador ou de alguma personagem. A sentença 1 descreve uma situação cotidiana, mas faz aspectualização do verbo, marcando-o pela cursivização do evento descrito. Como já vimos em 


\section{Algumas análises}

outros casos, o uso dessa forma verbal gera expectativa de ocorrência de evento concomitante ao descrito pelo verbo. Na sentença 2, a forma verbal aparece também aspectualizada, mas assume um caráter somente descritivo, por descrever o cenário em que a ação anterior ocorria. A juntura temporal que intermedeia as sentenças 2 e 3 precipita a informação que viria a seguir. Essa juntura temporal frustra a expectativa do evento concomitante esperado proposto na sentença 1. Tanto a juntura temporal quanto a sentença de orientação 3 apenas enfatizam que o herói não tinha nenhuma outra companhia humana. Duas outras junturas temporais se acumulam aumentando o tempo de leitura de forma que os eventos simultâneos previstos na sentença 1, próprios do tempo do discurso, ficaram em sentenças distantes, pelo tempo de leitura, provocando um aumento de expectativa e um consequente aumento de relatabilidade. 0 evento mais relatável, que ocorre na sentença 4, final da narrativa, entretanto, se apresenta como um fato incomum, mas não corresponde à expectativa gerada.

A queda abrupta de relatabilidade do evento mais relatável pressupõe uma mudança de perspectiva às incursões sobrenaturais na vida cotidiana. De forma bastante distinta daquela que descreve eventos dramáticos pela presença de elementos sobrenaturais - cabeças sem corpo, corpo sem cabeça, monstros selvagens, demônios, premonições de acidentes, dentre outras -, o 
evento mais relatável dessa narrativa apenas provoca estranhamento, ainda que nossos interpretantes iniciais pudessem ter sido elaborados com algum estado emocional um pouco mais intenso. Um dos recursos usados para a intensidade desse estado emocional se produziu por meio da dissociação temporal do tempo de leitura retardado, em relação ao tempo do discurso simultâneo. $\mathrm{O}$ artifício foi a utilização de junturas temporais lexicalizadas e sentenças de orientação atrasando o tempo de leitura.

\section{Texto 25: Super-Homem}

(Gustavo Araujo)

"Se você se concentrar com vontade, ele vai se mexer."

O pai sentou-se no sofá para assistir ao noticiário enquanto o menino se voltava para o bonequinho de plástico, um caubói segurando o chapéu sobre a cabeça.

Abaixando-se, estreitou os olhos e ordenou, num murmúrio insistente: "mexa, mexa..."

Súbito, viu o brinquedo acenar. Chamou o pai imediatamente. Em resposta, um riso gostoso, cúmplice, encheu a sala.

A lembrança atingiu-o como vento fresco. Subiu na ponta dos pés e observou-o, imóvel qual brinquedo. "Mexa, pai", pediu com toda a força, mas sabia, de algum modo, que tinha perdido seus poderes. ${ }^{290}$

\section{Tabela 20}

1 ac "Se você se concentrar com vontade, ele vai se mexer."

2 ac 0 pai sentou-se no sofá para assistir ao noticiário

jt enquanto 


\section{Algumas análises}

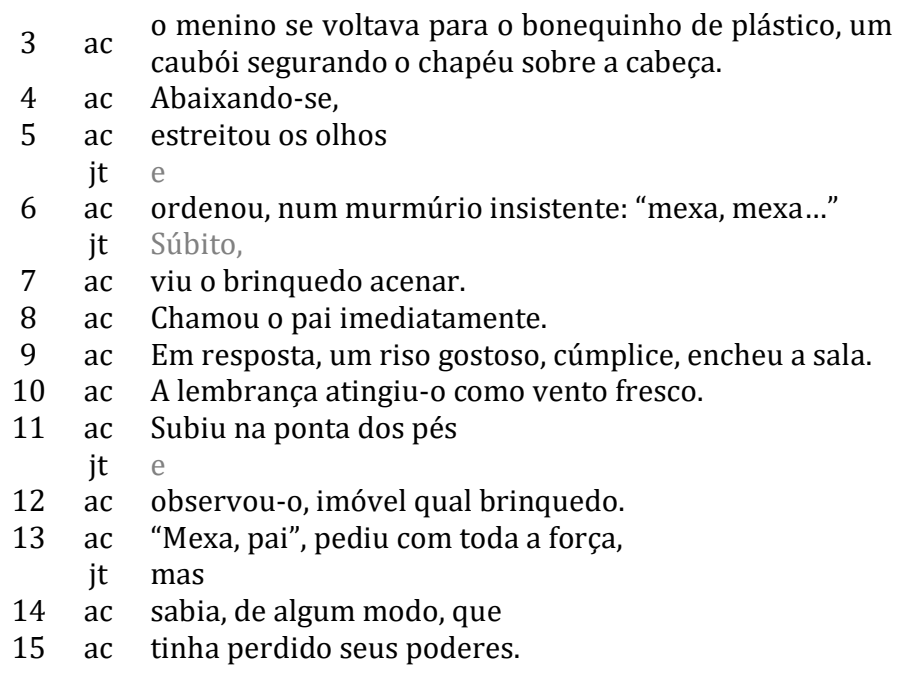

A narrativa que vai no Texto 25 tem seu início pela descrição da fala de uma personagem. Não há indicação da autoria da fala. Na sentença 2, há a descrição de uma cena cotidiana, que gera um interpretante masculino, adulto de classe média. Embora o autor não descreva a posição social da personagem, ele dá pista suficiente para essa elaboração, como "sentou-se no sofá", "assistir ao noticiário"... Essas expressões caracterizam um ambiente residencial familiar tipicamente urbano. A própria definição de "noticiário" leva a imaginar que se trata do desempenho de um papel masculino adequado, sobretudo pelo uso do artigo definido que nos torna, como leitor-modelo, coparticipantes da cena cuja programação televisiva nos seria igualmente familiar. Após uma juntura temporal que estabelece que a ação da sentença 3 é concomitante com a anterior, a sentença descreve um menino que 
brinca com um bonequinho, fazendo-nos imaginá-lo como criança. A ação vai marcada pelo imperfectivo, criando um certo dinamismo em nosso interpretante. A sentença 4, cujo verbo vai em forma cursiva, marcada pelo gerúndio, cria expectativa quanto à ação seguinte, que vai descrita logo no início da sentença 5 e imediatamente acompanhada, seja em tempo real seja em tempo do discurso, na sentença 6. Nessa sentença, o discurso direto do menino nos faz associar sua fala com a fala descrita na sentença 1, que agora sabemos ser de seu pai. Mas não só. Nosso interpretante agora recoloca as personagens, pai e filho pequeno, interagindo na mesma cena. Na sentença 7, nosso interpretante presume as fantasias da criança que se coloca na posição de leitor-modelo de seu pai, assumindo seu discurso como verdadeiro, a despeito de quaisquer outras interpretações possíveis. A canonicidade esperada é a de que "se meu pai falou que se eu me concentrar, ele vai se mexer; então isso vai acontecer". E é a crença que a personagem assume. A sentença 8 descreve a ação que é consequência direta da descoberta do menino: um acontecimento dessa magnitude não pode ser guardado em silêncio. Em seguida, na sentença 9, temos o comportamento do pai, que, nesse momento, congrega status de pai e de adulto, em que, feliz pela alegria do filho, também presume a ingenuidade da criança que assume com simplicidade as crenças da narrativa paterna. 


\section{Algumas análises}

A sentença 10 faz as vezes de uma juntura temporal que atua de forma a promover um salto no tempo do discurso. A expressão "A lembrança" que vai encabeçada pelo artigo definido nos faz retomar todos os eventos descritos da sentença 1 à 9 como antecedentes de "lembrança". Nossos interpretantes agora são colocados numa instância subjetiva da memória da personagem cujas ações serão descritas nas sentenças seguintes. Na sentença 11, a ação vai descrita com detalhes, "subir nas pontas dos pés" faz que nosso interpretante tenha, além de seu movimento, a intenção de alcançar um lugar mais alto. Ainda é uma criança. 0 resultado da ação vai na sentença 12 , em que compartilhamos com ele a visão do pai, agora, totalmente imóvel como era o brinquedo. A mesma crença - "se eu me concentrar, ele vai se mexer" vai retomada na sentença 13 para seu próprio pai. Nosso interpretante conjuga agora a expectativa do menino com a frustração de suas intenções. Seu status de criança, que garantia sua crença na narrativa paterna, deparou com a impossibilidade de se realizar. Estamos no ápice da relatabilidade do evento mais relatável. Nosso interpretante nos cria conflito entre desejo e carência. Nas sentenças 14 e 15, que finalizam a narrativa, a situação se decide, então, pela aceitação do conflito e a supressão da crença. 
Waldemar Ferreira Netto

306 


\section{Referências}

ADAMS, C. As populações caiçaras e o mito do bom selvagem: a necessidade de uma nova abordagem interdisciplinar.

Revista de Antropologia, v. 43, n. 1, p. 145-82, 2000.

AGOSTINHO, P. Mitos e outras narrativas kamayurá. Salvador: Universidade Federal da Bahia, 1974.

AMARAL, A. 0 dialeto caipira. São Paulo: Hucitec, 1982.

ANCHIETA, J. Cartas, informações, fragmentos históricos e sermões (1554-1594). Rio de Janeiro: Biblioteca de Cultura Nacional, 1933.

ANDRADE, M. de. Ensaio sobre a música brasileira. 4. Ed. Belo Horizonte: Itatiaia, 2006.

ANDRADE, M. de. Poesias completas. Ed. Crítica de Diléa Zanotto Manfio. Belo Horizonte: Itatiaia; Edusp, 1987.

AQUINO, T. Suma de teología. 4. ed. Trad. José Martorell Capó.

Madrid: Biblioteca de Autores Cristianos, 2001. Disponível em:

https://sumateologica.wordpress.com/download/. Acesso em: 4 jan. 2017.

ARISTÓTELES. Política. In: SARAMANCH, F. P. (Org.). Aristóteles. Obras. Madrid: Aguilar, 1982. p. 651-994.

ASSIS, J. M. M. A mão e a luva. Disponível em:

http://www.dominiopublico.gov.br/download/texto/bn000027.pdf. Acesso em: 14 fev. 2017.

ASSIS, J. M. M. Dom Casmurro. Disponível em:

http://www.dominiopublico.gov.br/download/texto/bv00180a.pdf. Acesso em: 14 fev. 2017.

ASSIS, J. M. M. Iaiá Garcia. Disponível em:

http://www.dominiopublico.gov.br/download/texto/bn000027.pdf. Acesso em: 14 fev. 2017.

ASSIS, J. M. M. Memorial de Aires. Disponível em:

http://www.dominiopublico.gov.br/download/texto/bv000214.pdf. Acesso em: 14 fev. 2017.

ASSIS, J. M. M. Pareceres. Disponível em:

http://www.dominiopublico.gov.br/download/texto/bn000155.pdf. Acesso em: 14 fev. 2017. 
AUSTIN, J. L. Quando dizer é fazer. Palavras e ação. Trad. Danilo Marcondes de Souza Filho. Porto Alegre: Artes Médicas, 1990.

AZEVEDO, A. A condessa Vésper. Disponível em: http://www.dominiopublico.gov.br/download/texto/bi000208.pdf Acesso em: 15 fev 2017.

AZEVEDO, A. Casa de pensão. Disponível em: http://www.dominiopublico.gov.br/download/texto/bv000014.pdf Acesso em: 15 fev. 2017.

AZEVEDO, A.o cortiço. Disponível em: http://www.dominiopublico.gov.br/download/texto/bv000015.pdf. Acesso em: 15 fev. 2017.

AZEVEDO, K. R.; ARRAIS, A. da R. 0 mito da mãe exclusiva e seu impacto na depressão pós-parto. Psicologia: reflexão e crítica, v. 19, n. 2, p. 269-276, 2006.

BALDIN, P. E.; NOGUEIRA, P. C. Fatores de risco para mortalidade infantil pós-neonatal. Revista Paulista de Pediatria, v. 26, n 2, p. 156-160, 2008.

BALDUS, H. Ensaios de etnologia brasileira. 2. ed. São Paulo: Nacional; Brasília: INL, 1979.

BALEÉ, W. Charles Wagley on changes in Tupí-Guaraní kinship classifications. Boletim do Museu Paraense Emílio Goeldi Ciências Humanas, v. 9, n. 3, p. 645-659, set./dez, 2014. BARBOSA, R. Obras seletas. Volume 6. Disponível em: http://objdigital.bn.br/Acervo_Digital/livros_eletronicos/obras_sele tas_vol6.pdf. Acesso em: 14 fev. 2017.

BARBOSA, R. Obras seletas. Volume 7. Disponível em: http://objdigital.bn.br/Acervo_Digital/livros_eletronicos/obras_sele tas_vol7.pdf. Acesso em: 14 fev. 2017.

BARBOSA, R. Obras seletas. Volume 8. Disponível em: http://objdigital.bn.br/Acervo_Digital/livros_eletronicos/obras_sele tas_vol8.pdf. Acesso em: 14 fev. 2017.

BARLEY, Nigel. The Innocent Anthropologist. Notes from a Mud Hut. London: Eland, 1983.

BARRETO, L. Cemitério dos vivos. Disponível em: http://www.dominiopublico.gov.br/download/texto/bn000047.pdf. Acesso em: 14 fev. 2017. 


\section{Referências}

BARRETO, L. Clara dos Anjos. Disponível em:

http://www.dominiopublico.gov.br/download/texto/bv000150.pdf Acesso em: 14 fev. 2017.

BARRETO, L. 0 triste fim de Policarpo Quaresma. Disponível em: http://www.dominiopublico.gov.br/download/texto/bv000159.pdf. Acesso em: 14 fev. 2017.

BARRETO, L. Os bruzundangas. Disponível em: http://www.dominiopublico.gov.br/download/texto/bv000149.pdf. Acesso em: 14 fev. 2017.

BARRETO, L. Recordações do escrivão Isaías Caminha. Disponível em:

http://www.dominiopublico.gov.br/download/texto/bv000157.pdf. Acesso em: 14 fev. 2017.

BAUMAN, Z. Identidade. Entrevista a Benedetto Vecchi. Trad. Carlos Alberto Medeiros. Rio de Janeiro: Zahar, 2005.

BENVENISTE, É. L'appareil formel de l'énonciation. In:

BENVENISTE, Émile. Problèmes de linguistique générale

2. Paris: Gallimard, 1974. p. 79-88.

BENVENISTE, É. A filosofia analítica e a linguagem. In:

Problemas de linguística geral. Trad. Maria da Glória Novak e Luiza Neri. São Paulo: Edusp, 1976. p. 297-305.

BENVENISTE, É. La philosophie analytique et le langage. In: . Problèmes de Linguistique Générale 1. Paris:

Gallimard, 1966. p. 267-277.

BENVENISTE, É. 0 aparelho formal da enunciação. In:

Problemas de linguística geral 2. Trad. Marco Antônio

Escobar. Campinas: Pontes, 1989. p. 81-90.

BENVENISTE, Émile. 0 vocabulário das instituições

indo-europeias. Volume II. Poder, Direito, Religião. Trad. Denise

Bottmann e Eleonora Bottmann. Campinas: Editora da Unicamp, 1985.

BERKELEY, G. Obras filosóficas. Trad. Jaimir Conte. São Paulo:

Editora da Unesp, 2010.

BERKELEY, G. Treatise concerning the principles of human

knowledge. Edited by David R. Wilkins, 2002. Disponível em: http://www.maths.tcd.ie/ dwilkins/Berkeley/HumanKnowledge/1 734/HumKno.pdf. Acesso em: 13 maio 2017. 
BLACKLESS, M. et al. How sexually dimorphic are we? Review and synthesis. American Journal of Human Biology, n. 12, p. 151-166, 2000.

BOAS, F. Review of Methode des Ethnologie by F. Graebner. Science, N. S., v. 34, n. 884, p. 804-810, 1911.

BOCCACCIO, G. Decamerão. Trad. Torrieri Guimarães. São Paulo: Abril Cultural, 1979.

BOURDIEU, P. A economia das trocas linguísticas. 0 que falar quer dizer. Trad. Sergio Micelli et alii. São Paulo: Edusp, 1996.

BRASIL. Constituição da República Federativa do Brasil, 1988. Disponível em: https://www.planalto.gov.br/ccivil_03/constituicao/constituicao.htm. Acesso em: 16 dez. 2016.

BRUNER, J. Atos de significação. Trad. Sandra Costa. Porto Alegre: Artes Médicas, 2002.

BRUNER, J. Narrative construction of reality. Critical Inquiry, v. 18, n, 1, p. 1-21, 1991.

BRUNER, J. Realidade mental, mundos possíveis. Trad. Arcos A. G. Domingues. Porto Alegre: Artes Médicas, 1997.

BUENO, A. Textos Clássico da China Antiga. Disponível em: http://chines-classico.blogspot.com.br/. Acesso em: 03 mar. 2017. BURKE, Peter. Linguagens e comunidades nos primórdios da Europa Moderna. Trad. Cristina Yamagami. São Paulo: Editora Unesp, 2010.

CADOGAN, L. Ayvu Rapyta. Textos míticos de los Mbyá-Guaraní del Guairá. Asunción: Fundación “León Cadogan”; CEADUC; CEPAG, 1992.

CADOGAN, L. Las creencias religiosas de los Mbyá-Guaraníes. Boletín de Filologia, Montevideo, n. 40-42, p. 671-683. 1949a.

CADOGAN, L. Síntesis de la medicina racional y mística Mbya-Guarani. América Indígena, v. 9, n. 1, p. 21-35, 1949 b.

CAGLIARI, L.C. Marcadores prosódicos na escrita. ANAIS DO XVIII SEMINÁRIO DO GEL. LORENA: GRUPO DE ESTUDOS LINGÜÍSTICOS DE SÃO PAULO, 1989. p. 195-203 Disponível em: http://www.gel.org.br/arquivo/anais/1309090746_26.cagliari_luiz. pdf. Acesso em: 30 set. 2015. 


\section{Referências}

CAMPANTE, F. R; CRESPO, A. N. R. V.; LEITE, F. P. G.

Desigualdade salarial ente raças no mercado de trabalho urbano brasileiro: aspectos regionais. Revista Brasileira de Economia, v. 58, n., 2, p. 185-510, 2004.

CANCLINI, N. G. Culturas híbridas. Trad. Ana Regina Lessa e Heloísa Pezza Cintrão. São Paulo: Edusp, 2003.

CÂNDIDO, A. Os parceiros do rio Bonito. Estudo sobre o caipira paulista e a transformação dos seus meios de vida. São Paulo: Livraria Duas Cidades, 1978.

CANTARELLI, M. 0 tratado de Roma e o sistema da justiça penal internacional: os princípios. Revista Esmafe: Escola de Magistratura Federal da 5a Região, n. 17, p. 11-26, mar. 2008.

CASTILHO, A. T. Introdução ao estudo do aspecto verbal na língua portuguesa. Tese (Doutorado) - Universidade Estadual Paulista “Júlio de Mesquita Filho”, Marília, 1968. CHARAUDEUAU, P.; MAINGUENEAU, D. Dicionário de análise do discurso. Trad. Fabiana Komesu. São Paulo: Contexto, 2004.

CHOMSKY, N. Skynner: Verbal Behavior. Review. Language, v. 35, n. 1, p. 26-58, 1959.

COLLAS, 0. et al. Aborto legal por estupro: primeiro programa público do pais. Bioética, n. 2, p. 81-85, 1994.

COMTE, A. Cours de philosophie positive. Premier tome. Paris: Rouen Frère, 1830. Disponível em: http://gallica.bnf.fr/ark:/12148/bpt6k76267p/f4.item. Acesso em: 2 jan. 2017.

COMTE, A. Cours de philosophie positive. Tome $4^{\mathrm{eme}}, 1$ partie. Paris: Bachelier, Imprimeur-Libraire, 1839.

COMTE, A. Curso de filosofia positiva. Trad. Jose Arthur Gianotti. In: GIANOTTI, J. A. (Org.). Comte: Discurso sobre o espírito positivo; Discurso preliminar sobre o conjunto do positivismo; Catecismo positivista. Seleção de textos de José Arthur Giannotti. Trad. José Arthur Giannotti e Miguel Lemos. São Paulo: Abril Cultural, 1978. p. 1-39.

CONDORCET, J.-A.-N. de C., marquis de. Esboço de um quadro histórico dos progressos do espírito humano. Trad. Carlos Alberto Ribeiro de Moura. Campinas: Editora da Unicamp, 2013. CORALINA, C. Vintém de cobre: meias confissões de Aninha. São Paulo: Global, 2001. 
COSTA, A. M. C. I. A escola na república velha. Expansão do ensino primário em São Paulo: EDEC, 1983.

CUNHA, C.; CINTRA, L. Nova gramática do português

contemporâneo. Rio de Janeiro: Nova Fronteira, 1985.

CUNHA, E. À margem da história. Disponível em:

http://www.dominiopublico.gov.br/download/texto/bn000019.pdf.

Acesso em: 14 fev. 2017.

CUNHA, E. Contrastes e Confrontos. Disponível em:

http://www.dominiopublico.gov.br/download/texto/bn000017.pdf.

Acesso em: 14 fev. 2017.

CUNHA, E. Os sertões. Disponível em:

http://www.dominiopublico.gov.br/download/texto/bn000153.pdf.

Acesso em: 14 fev. 2017.

DARVIN, C. A expressão das emoções no homem e nos animais.

São Paulo: Companhia das Letras, 2000.

DEAN, W. A industrialização de São Paulo (1880-1945). Trad.

Octávio Mendes Cajado. São Paulo: Difel, 1971.

DEVEREUX, G. Ensayos de etnopsiquiatria general. Trad.

Francisco Monge. Barcelona: Barral Editores, 1973.

DIXON, R. M. W. The rise and fall of languages. Cambridge:

Cambridge University Press, 1997.

DUPIEUX, Q. Rubber: o pneu assassino. 2010. Disponível em:

https://www.youtube.com/watch?v=q0k9dd8qVNs. Acesso em: 24 jan. 2017.

DURKHEIM, É. As regras do método sociológico. Trad. Paulo

Neves. São Paulo: Martins Fontes, 2014.

DURKHEIM, É. Da divisão do trabalho social. Trad. Eduardo

Brandão. São Paulo: Martins Fontes, 1999.

ECO, U. Lector in fabula. A cooperação interpretativa nos textos narrativos. Trad. Attílio Cancian. São Paulo:

Perspectiva, 2004.

ECO, U. Seis passeios pelos bosques da ficção. Trad.

Hildegard Feixt. São Paulo: Companhia das Letras, 1994.

EDGERTON, R. B. Polkot intersexuality: an east afrikan

example of the resolution of sexua incongruity. American

Anthropologist, n. 66, p. 1288-1299, 1964.

ELDREDGE, N.; GOULD, S. J. Punctuated equilibria: an alternative to phyletic gradualism. In: In: SCHOPF, T. J. M. (Ed.). Models in 


\section{Referências}

Paleobiology. San Francisco: Freeman Cooper \& Co.; 1972. p. 82-115

ELIAS, N. 0 processo civilizador. Trad. Ruy Jungmann. Rio de Janeiro: Jorge Zahar, 1993. 2. v.

ERNOUT, A.; MEILLET, A. Dictionnaire étymologique de la langue latine. Histoire des mots. 4. ed. corr. e aum. por Jacques André. Paris: Klincksieck, 1979.

FAUSTO, C. De primos e sobrinhas: terminologia e aliança entre os Parakanã (Tupi) do Pará. In: CASTRO, E. V. (Org.). Antropologia do parentesco. Estudos ameríndios. Rio de Janeiro: Editora UFRJ, 1995. p. 61-119

FERREIRA NETTO, W. Aspectos da influência do adstrato tupi no léxico do português do Brasil. Linha d'Água, n. 8, p. 23-30, 1993.

FERREIRA NETTO, W. Os índios e a alfabetização. Aspectos da educação escolar entre os Guarani de Ribeirão Silveira. São Paulo: Paulistana, 2012. DOI 10.4322/978-85-99829-42-4 FERREIRA NETTO, W. Tradição Oral e construção de narrativas. São Paulo: Paulistana, 2008. DOI 10.4322/97885-99829-26-4

FERREIRA, A. B. de H. Novo dicionário da língua portuguesa. 2. ed. rev. e aum. Rio de Janeiro: Nova Fronteira, 1986.

FESTINGER, L. Teoria da dissonância cognitiva. Trad. Eduardo Almeida. Rio de Janeiro: Zahar, 1975.

FIORIN, J. L. A construção da identidade nacional brasileira.

Bakhtiniana, v. 1, n. 1, p. 115-126, 2009.

FRAZER, J. G. 0 ramo de ouro. Trad. Waltensir Dutra. São Paulo: Círculo do Livro, 1982.

FREGE, G. Sobre o sentido e a referência. (Texto publicado pela primeira vez em 1892). In: FREGE, G. Lógica e filosofia da linguagem. Seleção, introdução, trad. do alemão e notas de Paulo Alcorofado. São Paulo: Cultrix; Editora da Universidade de São Paulo, 1978. p. 59-86.

FREYTAG, Gustav. Freytag's Technique of the Drama; an exposition of dramatic composition and art. an Authorized translation from the 6th German Ed. by Elias J. MacEwan. New York: Benjamin Blom, 1968.

GALEMBECK, P. T. 0 turno conversacional. In: PRETI, D. Análise de textos orais. São Paulo: FFLCH/USP, 1995. p. 55-79. 
GALLOIS, D. T. Jipohan é gente como você. In: INSTITUTO SOCIOAMBIENTAL. Povos indígenas do Brasil. Disponível em: https://pib.socioambiental.org/pt/c/no-brasil-atual/narrativas-indi genas/narrativas-zoe. Acesso em: 06 mar. 2017.

GEERTZ, C. A interpretação das culturas. Trad. Rio de Janeiro: Guanabara Koogan, 1989.

GEERTZ, C. Common sense as a cultural system. In: Local knowledge. New York: Basic Books, 1983. p. 73-93.

GEERTZ, C. 0 senso comum como um sistema cultural. In: 0 saber local. Novos ensaios em antropologia interpretativa. Trad. Vera Mello Joscelyne. Petrópolis: Vozes, 1999. p. 111-141. GELLNER, E. El arado, la espada y el libro. La estructura de la história humana. Trad. Angélika Scherp do original inglês de 1988. México: Fondo de Cultura Económica, 1992.

GELLNER, E. Language and solitude. Wittgenstein, Malinowski and the Habsburg Dilemma. Cambridge: Cambrige University Press, 2004.

GELLNER, E. Linguagem e solidão. Uma interpretação do pensamento de Wittgenstein e de Malinowski. Trad. Jorge Manuel Costa e Pinho. Lisboa: Edições 70, 2001.

GELLNER, E. Nações e nacionalismo. Trad. Inês Vaz Pinto. Lisboa, Gradiva, 1993.

GENETTE, G. Discurso da narrativa. Ensaio de método. Trad. Fernando Cabral Martins. Lisboa: Arcadia, 1979.

GENETTE, G. Figures III. Paris: Seuil, 1972.

GENETTE, G. Fronteiras da narrativa. In: BARTHES, R. et al. Análise estrutural da narrativa. Pesquisas semiológicas. 4. ed. Trad. Maria Zélia Barbosa Pinto. Petrópolis: Vozes, 1971. p. 255-285.

GENETTE, G.; BEN-ARI, N; MCHALE, B. Fictional Narrative, Factual Narrative. Poetics Today, v. 11, n. 4, p. 755-774, 1990.

GIDDENS, A. Modernidade e identidade pessoal. Nova trad. Miguel Vale de Almeida. Oeiras: Celta, 2001.

GOFFMAN, E. A representação do eu na vida cotidiana. Trad. Maria Célia Santos Raposo. 13. ed. Petrópolis: Vozes, 2005.

GOFFMAN, E. Footing. In: . Forms of talk. Philadelphia:

University of Pennsylvania Press, 1981, p. 124-159

GOFFMAN, E. Footing. Semiotica, v. 25, n. 1, p. 1-30, 1979. 


\section{Referências}

GOFFMAN, E. Footing. Trad. Beatriz Fontana. In: RIBEIRO, B. T.; GARCEZ, P. M. (Org.). Sociolinguística interacional. Antropologia, linguística e sociologia em análise do discurso. Porto Alegre: AGE, 1998. p. 70-97.

GONÇALVES, M. A. O veredicto. Capitu absolvida. Folha de S. Paulo, ilustrada, São Paulo, 25/jun/1999. Disponível em:

<http://www1.folha.uol.com.br/fsp/ilustrad/fq25069914.htm>. Acesso em: 24 jan. 2017.

GREIMAS, A. J.; COURTÉS, J. Dicionário de semiótica. Trad. Alceu

Dias Lima et alii. São Paulo: Cultrix, s.d.

GRICE, H. P. Lógica e conversação. In: DASCAL, M. (Org.)

Fundamentos metodológicos da linguística. Problemas, críticas, perspectivas da linguística. Volume IV: pragmática. Trad. Wanderley Geraldi. Campinas: Edição do Autor, 1982. p. 81-103

HALBWACHS, M. A memória coletiva. Trad. Beatriz Sidou. São Paulo: Centauro, 2006.

HALL, S. Identidades mínimas. Trad. Izabel Murat Burbridge. Nossa América, n. 13, p. 22-29, 1997/1998.

HALL, S. Minimal selves. In: APPIGNANESI, Lisa (Ed.) et all. Identity of the Real Me: post-mordernism and the question of identity. ICA Documents 6. London: Institute of Contemporary Arts, 1987. p. 44-46. Disponível em:

http://site.ufvjm.edu.br/mpich/files/2013/04/HALL-Minimal-Selve s.pdf. Acesso em: 24 jan. 2017.

HAMILTON, W. Conditions of the thinkable. In: Discussions of philosophy and literature, education and university reform. New York: Harper \& Brothers, 1861. Disponível em: https://archive.org/details/discussionsonphi00hami. Acesso em: 24 jan. 2017.

HAMILTON, William. Lectures on metaphysics and logic. v. I Metaphysics . Boston: Gould and Lincoln, 1860. Disponível em: https://archive.org/details/lecturesonmetap03veitgoog. Acesso em: 24 jan. 2017.

HELLER, A. Sociología de la vida cotidiana. Trad. da versão italiana e da versão alemã autorizada pela autora por José Francisco Ivass e Enric Perez Nadal. Barcelona: Península, 1977.

HILL, W. W. The status of the hermaphrodite and transvestite in navaho culture. American Anthropologist, N. S., n. 37, p. 273-279, 1935. 
HUMBOLDT, W. von. Sobre la diversidad de la estructura del lenguaje humano y su influencia sobre el desarrollo espiritual de la humanidad. Trad. do alemão de Ana Agud. Barcelona: Anthopos; Madrid; Ministerio de Educación y Ciencia, 1990.

HUME, D. A treatise of human nature. Reprinted from the original edition in three volumes. Oxford: Clarendon, 1965.

HUME, D. Tratado da natureza humana. Uma tentativa de introduzir o método experimental de raciocínio nos assuntos morais. Trad. Déborah Danowski. 2. ed. São Paulo: Editora Unesp, 2009.

ILARI, R. A expressão do tempo em português. São Paulo: Contexto, 1997.

JAKOBSON, R. Closing Statement: Linguistic and Poetics. In.: SEBEOK, T. A. (Ed.). Style in Language. New York: The Technology Press of Massachusetts Institute of Technology; London, John Wiley \& Sons, 1960.

JAKOBSON, R. Linguística e poética. In.: BLIKSTEIN, I. (Org.).

Linguística e comunicação. Trad. Izidoro Blikstein e José Paulo Paes. São Paulo: Cultrix; Editora da Universidade de São Paulo, 1969.

JAKOBSON, R. Linguística e teoria da comunicação In:

Linguística e comunicação. Trad. Izidoro Blikstein; José Paulo Paes. São Paulo: Cultrix, s.d., p. 73-86.

JAKOBSON, R. Metalanguage as a linguistic problem. In: The framework of language. Michigan: University of Michigan, 1980. p. 81-92.

JAKOBSON, R. Selected Writings II: words and language. THe Hague: Mouton, 1971.

JUNQUEIRA, C. Antropologia indígena. Uma (nova) introdução. São Paulo: Educ, 2008.

JUNQUEIRA, C. Os índios de Ipavu. São Paulo: Ática, 1978.

KEESING, R. M. Theories of culture. Annual Review of Anthropology, n. 3, p. 73-97, 1974.

KOCH-GRÜNBERG, T. Mitos e lendas dos índios Taulipang e Arekuná. Revista do Museu Paulista, São Paulo, Nova Série, n. 7, p. 9-202, 1953.

KÖHLER, W. Gestalt psychology. An introduction to new concepts in modern psychology. New York: Liveright, 1970.

KRICKERBERG, W. Mitos y leyendas de los aztecas, incas, mayas y muiscas. México: Fondo de Cultura Económica, 1999. 


\section{Referências}

LABOV, W. Some further steps in narrative analysis. The Journal of Narrative and Life History, v. 7, n. 1-4, p. 395-415, 1997.

LABOV, W.; WALETZKY, J. Narrative Analysis: oral versions of personal experience. In: HELM, J. (Ed.). Essays on the Verbal and Visual Arts. Proceedings of the 1966 Annual Spring Meeting of the American Ethnological Society. Seatle: American Ethnological Society/ University of Washington Press, 1967. p. 12-44.

LADEIRA, M. I. 0 caminhar sob a luz. Território mbya à beira do oceano. São Paulo: Fapesp; Editora Unesp, 2007.

LAMARCK, Jean Baptiste de Monet, Cabalero de. Filosofía zoológica. Trad. Jaume Serrasousas. Barcelona: Editorial Alba Fulla; Editorial Fontalba, 1989.

LARA, S. H. Escravidão, cidadania e história do trabalho no Brasil.

Projeto história. Revista do programa de estudos pós-graduados de história, n. 16, p. 25-38, 1998.

LARAIA, R. B. A estrutura do parentesco tupi. In: GUDSCHINSKY, S. C. (Org.). Estudos sobre línguas e culturas indígenas. Brasília: SIL, 1971. p. 174-212.

LARAIA, R. B. A. Cultura. Um conceito antropológico. 17. ed. Rio de Janeiro: Jorge Zahar, 2004.

LE BRETON, D. Antropologia dos sentidos. Trad. Francisco Morás. Petrópolis: Vozes, 2016.

LE GOFF, J. As mentalidades: uma história antiga. In: LE GOFF, J.;

NORA, P. História: novos objetos. Trad. Terezinha Marinho. 3. ed. Rio de Janeiro: Francisco Alves, 1989. p. 68-83.

LÉVI-STRAUSS, C. A estrutura dos mitos. In: Antropologia

estrutural. Trad. Júlio César Melatti. Rio de Janeiro: Tempo Brasileiro, 1975. p. 237-265.

LÉVI-STRAUSS, C. A origem dos modos à mesa: Mitológicas III. São Paulo: Cosac Naify, 2006.

LÉVI-STRAUSS, C. La pensée sauvaje. Paris: Plon, 1962.

LÉVI-STRAUSS, C. Raça e história. In: ------ Antropologia

estrutural dois. Trad. Maria do Carmo Pandolfo. Rio de Janeiro:

Tempo Brasileiro, 1976. p. 328-366.

LINHARES, H. Contribuição à história das lutas operárias no

Brasil. 2. ed. São Paulo: Alfa-Ômega, 1977. 
LINTON, R. 0 homem. Uma introdução à antropologia. Trad. Lavínia Vilela. São Paulo: Martins Fontes, 1981.

LIVRO das mil e uma noites. Introdução, notas e tradução do árabe Mamede Mustafá Jarouche. 2. ed. São Paulo: Globo, 2005.

LUNA. N. Maternidade desnaturada: uma análise da barriga de aluguel e da doação de óvulos. Cadernos Pagu, n. 19, p. 233-278, 2002.

MAINGUENEAU, D. Ethos, cenografia, incorporação. In:

AMOSSY, R. (Org.). Imagens de si no discurso. A construção do Ethos. Trad. Dilson Ferreira da Cruz et alii. São Paulo: Contexto, 2008. p. 69-92.

MANDLER, J. H. Stories, scripts and scenes: aspects of schema theory. Hillsdale: Lawrence Erlbaum Associates, 1984.

MARTINS, J. de S. 0 estudo sociológico da mentira no Brasil. In: Uma sociologia da vida cotidiana. São Paulo: Contexto, 2014. p. 105-108.

MEAD. G. Mind, self, and society from the standpoint of a social behaviorist. Chicago: The University of Chicago Press, 1962.

MEDINA, A. De marré o quê? Revista de História, 9/1/2009.

Disponível em:

http://www.revistadehistoria.com.br/secao/artigos/de-marre-o-que. Acesso em: 24 jan. 2017.

MELATTI, J. C. Índios do Brasil. São Paulo, Hucitec, 1983.

MENEZES, F. A acústica musical em palavras e sons. Cotia: Ateliê Editorial; São Paulo: Fapesp, 2003.

MERTON, R. Sociologia. Teoria e estrutura. Trad. Miguel Maillet. São Paulo: Mestre Jou, 1970.

MINDLIN, B. Nós Paiter. Os Suruí de Rondônia. Petrópolis: Vozes, 1985.

MINDLIN, B. Tuparis e Tarupás. Narrativas dos índios Tuparis de Rondônia. São Paulo: Instituto de Antropologia e Meio Ambiente; Brasiliense; Edusp, 1993.

MORSE, R. M. Formação histórica de São Paulo (de comunidade à metrópole). São Paulo: Difusão Europeia do Livro, 1970.

MOURA NEVES, M. H. A vertente grega da gramática tradicional. Brasília: Hucitec; Editora Universidade de Brasília, 1987. 


\section{Referências}

MUSSOLINI, G. Aspectos da cultura e da vida social no litoral brasileiro. Revista de Antropologia, v. 1, n. 2, p. 81-97, 1953.

NIMUENDAJU, C. U. As lendas da criação e destruição do mundo como fundamentos da religião dos

Apapocuva-Guarani. Trad. Charlotte Emmerich e Eduardo B. Viveiros de Castro. São Paulo: Hucitec; Editora da Universidade de São Paulo; 1987.

NIMUENDAJU, C. U. Fragmentos de religião e tradição dos índios Xipaya. Trad. F. W. Lommes. Religião e Sociedade, n. 7, p. 6-47, 1981.

NIMUENDAJU, C. U. Mitos indígenas inéditos na obra de Curt Nimuendaju. Revista do Patrimônio Histórico e Artístico Nacional, n. 21, p. 64-110, 1986.

OLIVEIRA FILHO, J. P. (Org.) A viagem da volta. Etnicidade, política e reelaboração cultural no Nordeste indígena. Rio de Janeiro: Contra Capa Livraria, 1999.

OLIVEIRA FILHO, J. P. Ensaios em antropologia histórica. Rio de Janeiro: UFRJ, 1999.

OLIVEIRA, R. C. Identidade, etnia e estrutura social. São

Paulo: Livraria Pioneira, 1976.

PAINE, T. Common Sense. Disponível em:

https://www.gutenberg.org/files/147/147-h/147-h.htm. Acesso em: 24 jan. 2017.

PAINE, T. Senso comum. Trad. Pedro Paulo Martinez. São Paulo: Martin Claret, 2005.

PAÑCATANTRA. Fábulas indianas - livro I. Trad. Maria da Graça Tesheiner et alii. São Paulo: Humanitas, 2003.

PAÑCATANTRA. Fábulas indianas - livro IV e C. Trad. Maria da Graça Tesheiner et alii. São Paulo: Humanitas, 2013.

PAÑCATANTRA. Fábulas indianas - livros II e III. Trad. Maria da Graça Tesheiner et alii. São Paulo: Humanitas, 2008.

PAVLOV, I. P. A psicologia e a psicopatologia experimentais dos animais. (Discurso pronunciado em 1903). In: PAVLOV, I. P. Textos escolhidos. Trad. do inglês Raquel Moreno, Hugolino de Andrade Uflaker e Elena Olga Maria Andreoli. São Paulo: Abril Cultural, 1984. p. 15-27.

PAVLOV, I. P. Os primeiros passos certos no caminho de uma nova investigação. (Discurso do Prêmio Nobel em 1904). In: PAVLOV, I. P. 
Textos escolhidos. Trad. do inglês Raquel Moreno, Hugolino de Andrade Uflaker e Elena Olga Maria Andreoli. São Paulo: Abril Cultural, 1984. p. 3-14

PEIRCE, Ch. S. A fixação das crenças In: MOTA, O. S.; HEGENBERG, L. (Org.) Semiótica e filosofia. Textos escolhidos de Charles Sanders Peirce. São Paulo: Cultrix/Edusp, 1975. p. 71-92

PEIRCE, Ch. S. Classificação dos signos. In: MOTA, O. S.; HEGENBERG, L. (Org.) Semiótica e filosofia. Textos escolhidos de Charles Sanders Peirce. São Paulo: Cultrix/Edusp, 1975. p. 93-114

PEIRCE, Ch. S. Escritos coligidos. Trad. Armando Mora D'Oliveira e Sergio Pomerangblum. São Paulo: Abril Cultural, 1974. (Os pensadores).

PEIRCE, Ch. S. O ícone, o indicador e o símbolo. In: MOTA, O. S.; HEGENBERG, L. (Org.) Semiótica e filosofia. Textos escolhidos de Charles Sanders Peirce. São Paulo: Cultrix; Edusp, 1975. p. 115-134 PEIRCE, Ch. S. Semiótica. São Paulo: Perspectiva, 2015.

PENA, S. D. J. Retrato molecular do Brasil, versão 2001. In: . (Org.). Homo brasilis. Aspectos genéticos, linguísticos, históricos e socioantropológicos da formação do povo brasileiro. Ribeirão Preto: Funpec-SP, 2002. p. 11-28.

PEREIRA, N. Moronguetá. Um decameron indígena. Rio de Janeiro: Civilização Brasileira, 1967.

PEREZ, T. G. El aprendizaje de la maternidad: discursos para la educación de las mujeres en España (siglo XX).

Convergencia, Revista de Ciencias Sociales, n. 46, p. 91-117, 2008.

PLATÃO. Obras completas. Trad. del griego Maria Araujo et alii. Madrid: Aguilar, 1981.

POPPER, K. A lógica da pesquisa científica. 2. ed. Trad. Leonidas Hegenberg e Octanny Silveira da Mota. São Paulo: Cultrix, 1974. PRADO Jr, C. História econômica do Brasil. São Paulo: Brasiliense, 1963.

PRIETSCH, S. O. M. et al. Gravidez não planejada no extremo Sul do Brasil: prevalência e fatores associados Cadernos de Saúde Pública, v. 27, n. 10, p. 1906-1916, 2011.

PROPP, V. Morfologia do Conto Maravilhoso. Trad. Jasna Paravich Sarhan. Rio de Janeiro: Forense Universitária, 2006. 


\section{Referências}

RADCLIFFE-BROWN, A. R. 0 estudo dos sistemas de parentesco. Trad. Sônia Regina Pacheco Alves. In: LARAIA, R. B (Org.). Organização social. Rio de Janeiro: Zahar, 1969. p. 50-87. REIS, R. The impact of television viewing in the Brazilian amazon. Human Organization, v. 57, n. 3, p. 300-306, 1998.

REY, M. J. B. Antropología de la mujer: cognición, lengua e ideología cultural. Barcelona: Anthropos, 1988.

RIBEIRO, D. Culturas e línguas indígenas do Brasil. Educação e ciências sociais, v. 2, n. 6, p. 1-102, 1957.

RORTY, R. A trajetória do pragmatista. In: em ECO, U. Interpretação e superinterpretação. 2. ed. Trad. Monica Stahel. São Paulo: Martins Fontes, 2005. p. 105-127.

RORTY, R. Contingência, ironia e solidariedade. Trad. Vera Ribeiro. São Paulo: Martins, 2007.

ROSENFIELD, I. A invenção da memória: uma nova visão do cérebro. Trad. Vera Ribeiro. Rio de Janeiro: Nova Fronteira, 1994.

RUSSEL, B. A filosofia do atomismo lógico. In: Ensaios escolhidos. Seleção de textos de Hugh Mattew Lacey. Trad. do inglês Pablo Rubén Mariconda. São Paulo: Abril Cultural, 1978. (Os pensadores)

SANTOS, J. T. Platão e a escolha do diálogo como meio de criação filosófica. Humanitas, n. 46, p. 163-176, 1994.

SAUSSURE, F. Curso de linguística geral. Trad. Antônio Chelini, José Paulo Paes e Izidoro Blikstein. São Paulo: Cultrix, 1972.

SCANTIMBURGO, J. Os paulistas. São Paulo: Imprensa Oficial, 2006. SCHADEN, E. Aspectos fundamentais da cultura guarani. 3. ed. São Paulo: E.P.U.; Edusp, 1974.

SCHADEN, E. Os primitivos habitantes do território paulista. Revista de História, n. 18, p. 385-406, 1954.

SCHAEFFER, P. Traité des objets musicaux: essai interdisciplines. Paris: Seuil, 1966.

SHANNON, C. E.; WEAVER, W. A teoria matemática da comunicação. Trad. Orlando Agueda. Rio de Janeiro: Difel, 1975. SHANNON, C. E.; WEAVER, Warren. The Mathematical Theory of Communication. Urbana: The University of Illinois, 1964.

SILVA, A. B. A. A civilização indígena do Uaupés. Observações antropológicas, etnográficas e sociológicas. 2. ed. Roma: Libreria Ateneo Salesiano, 1977. 
SILVERWOOD-COPE, P. L. Os Maku. Povo caçador do noroeste da Amazônia. Brasília: Editora Universidade de Brasília, 1990.

SIMMEL, G. Questões fundamentais da sociologia. Rio de Janeiro: Zahar, 2006.

SKINER, B. F. Verbal behavior. New York: Appleton, Century-Crofts, 1957.

SKINNER, B. F. O comportamento verbal. Trad. Maria da Penha Villalobos. São Paulo: Cultrix; Editora da Universidade de São Paulo, 1978.

SOARES, S. S. D. O Perfil da Discriminação no Mercado de Trabalho Homens Negros, Mulheres Brancas e Mulheres Negras. Textos para discussão, n. 769, p. 1-26, 2000. Disponível em:

http://www.ipea.gov.br/portal/images/stories/PDFs/TDs/td_0769. pdf. Acesso em: 24 jan. 2017.

SPENCER, H. Do progresso. Sua lei e sua causa. Trad. Eduardo Salgueiro. Lisboa: eBookesbrasil, 2002. Disponível em:

http://www.ebooksbrasil.org/adobeebook/progresso.pdf. Acesso em: 3 set. 2016.

SPENCER, H. Progress: its law and cause. With other disquisition.

New York: J. Fitzgerald, 1881. p. 233-285. Disponível em: https://archive.org/details/progressitslawca00spen. Acesso em: 24 jan. 2017.

SPENCER, H. The origin of music. Mind, v. 15, n. 60, p. 449-468, October, 1890.

TODOROV, T. Teorias do símbolo. Trad. do francês de Roberto Leal Ferreira. São Paulo: Editora Unesp, 2013.

TUBERT, S. Mulheres sem sombra. Maternidade e novas tecnologias reprodutivas. Trad. Graciela Rodriguez. Rio de Janeiro: Rosa dos Ventos, 1996.

VANSINA, J. A tradição oral e sua metodologia. In: KI-ZERBO, J. (Org.) História geral da África. Metodologia e pré-história da África. São Paulo: Ática, 1982. p. 157-179

VARGAS, M. V. Verbo e práticas discursivas. São Paulo: Contexto, 2011.

VASCONCELLOS, J. L. Tradições populares em Portugal. 2. ed. rev. e aum. Lisboa: Imprensa Nacional; Casa da Moeda, 1986.

VEGINI, V.; VEGINI, R. L.; FERREIRA NETTO, W. o monstruoso

Mapinguari pan-amazônico. Uma sucessão de adaptações aloindígenas. Porto Velho: Temática, 2015. 


\section{Referências}

VELHO, G. Individualismo e cultura. Notas para uma antropologia da sociedade contemporânea. 7. ed. Rio de Janeiro: Jorge Zahar, 2004.

VEREA, C. P. Malas madres: la construcción social de la maternidad. Debate Feminista, n. 30, p. 12-34, 2004.

VEREA, C.P. Maternidad: historia y cultura. Revista de Estudios de Género, La Ventana, n. 22, p. 35-67, 2005.

VIANA, N. Senso comum, representações sociais e representações cotidianas. Bauru: Edusc, 2008.

VIEIRA, M. F; FERREIRA NETTO, W. 0 saci da tradição local no contexto da mundialização e da diversidade cultural. In: ENCONTRO NACIONAL DE LINGUAGEM E IDENTIDADE, 1., 2008, Campinas. Anais... Campinas, 2008. p. 28-29.

VIEIRA, M.de F. 0 Saci da tradição local no contexto da mundialização e da diversidade cultural. Tese (Doutorado) Universidade de São Paulo, São Paulo, 2009.

WAGLEY, C.; GALVÃO, E. O parentesco tupi-guarani. Boletim do Museu Nacional, N. S., n. 6, p. 1-24, 1946.

WATSON, J. B. Behaviorsm. London: Kegan Paul, Trench, Trubner \& Co, 1925.

WERTHEIMER, M. Laws of organization in perceptual forms. In: ELLIS, W. (ed.). A source book of gestalt psychology. London: Routledge \& Kegan Paul, 1938. p. 71-88. (por Christopher D. Gree). Disponível em: <psychclassics.yorku.ca>. Acesso em: 24 jan. 2017. WINCKEL, F. Music, sound and sensation. A modern exposition. New Yourk: Dover Publications, 1967.

WOLF, N. 0 mito da beleza. Como as imagens de beleza são usadas contra as mulheres. Trad. Waldéa Barcelos. Rio de Janeiro: Rocco, 1992.

XAVIER, M. F.; MATEUS, M. H. Dicionário de termos linguísticos. Volume 1. Lisboa: Cosmos, s.d. 
Waldemar Ferreira Netto 


\section{Notas}

\section{Notas}

1 Para uma discussão sobre esse termo, envolvendo tanto a narrativa de ficção como a factual, ver Genette (1990).

2 Le Goff (1989, p. 78).

3 “Como podemos ver, toda cidade é uma espécie de comunidade, e toda comunidade se formou tendo como fim um determinado bem [...] Portanto, é evidente que, enquanto todas as comunidades tendem a algum bem, a comunidade superior a todas e que inclui em si mesma todas as demais deve fazer isto em um grau supremo, acima de todas e aspira ao mais alto de todos os bens, e essa é a comunidade chamada Cidade, a associação política". (ARISTÓTELES, 1982, p. 675, tradução minha do espanhol)

"Por outro lado, a comunidade primária constituída por várias famílias para a satisfação das necessidades que já não são as cotidianas simplesmente é o povoado. 0 povoado ou aldeia, segundo a explicação mais natural, parece ser uma colônia de uma família, formada pelo que alguns chamam de "companheiros de leite", filhos e filhos dos filhos". (ARISTÓTELES, 1982, p. 678, tradução minha do espanhol)

"Toda ciudad es, como podemos ver, una especie de comunidad, y toda comunidad se ha formado teniendo como fin un determinado bien [...]. Es, por tanto, evidente que, mientras que todas las comunidades tienden a algún bien, la comunidad superior a todas y que incluye en sí todas las demás debe hacer esto en un grado supremo por encima de todas, y aspira al más alto de todos los bienes; y esa es la comunidad llamada Ciudad, la asociación política". (ARISTÓTELES, 1982, p. 675)

Por otra parte, la comunidad primaria constituida por varias familias para satisfacción de las necesidades ya no meramente cotidiana es el pueblo. El pueblo o aldea, según la explicación 
más natural, parece ser una colonia de una familia, formada por los que algunos llaman "compañeros de leche", hijos e hijos de los hijos". (ARISTÓTELES, 1982, p. 678)

4 "[...] a cidade é, por natureza, anterior à família e a cada um de nós tomados individualmente. De fato, é necessário que o todo seja anterior à parte, pois, uma vez destruído o corpo inteiro, não haverá nem pé nem mão [...] É, pois, evidente que a cidade também é, por natureza, anterior ao indivíduo; pois, se o indivíduo, tomado isoladamente, não se basta a si mesmo, será (em relação à cidade) como as partes em relação ao todo nos casos mencionados. Quanto ao que incapaz de formar parte de uma comunidade ou ao que não necessita dela por bastar-se a si próprio, não é, de modo algum, parte de uma cidade, com o que ou é mais propriamente um animal ou um deus." (ARISTÓTELES, 1982, p. 681-680, tradução minha do espanhol)

[...], la ciudad es, por naturaleza, anterior a la familia y a cada uno de nosotros tomados individualmente. Es, en efecto, necesario que ele todo sea anterior a la parte; pues, una vez destruido el cuerpo entero no habrá pie ni mano, [...] Es, pues, evidente que la ciudad es también anterior por naturaleza al individuo: pues, si el individuo, tomado en solitario, no se basta a sí mismo, será (en relación a la ciudad) como las partes respecto al todo en los casos mencionados. En cuanto al que es incapaz de formar parte de una comunidad o al que no necesita de ello por bastarse a sí mismo, no es en modo alguno parte de una ciudad, con lo que es o bien una fiera o un dios. (ARISTÓTELES, 1982, p. 681-680)

${ }^{5}$ Condorcet $(2009$, p. 20$)$. No original: "Le premier état de civilisation où l'on ait observé l'espèce humaine, est celui d'une société peu nombreuse d'hommes subsistant de la chasse et de la pêche, ne connoissant que l'art grossier de fabriquer leurs armes et quelques ustensiles de ménage, de construire ou de se creuser des logemens, mais ayant déjà une langue pour se communiquer leurs besoins, et un petit nombre d'idées morales, dont ils déduisent des règles communes de conduite, 
vivant en familles, se conformant à des usages généraux qui leur tiennent lieu de lois, et ayant même une forme grossière de gouvernement."

${ }^{6}$ Condorcet $(2009$, p. 25). No original: "Dans la première, où les récits des voyageurs nous montrent l'état de l'espèce humaine chez les peuples les moins civilisés, nous sommes réduits à deviner par quels degrés l'homme isolé, ou plutôt borné à l'association nécessaire pour se reproduire, a pu acquérir ces premiers perfectionnemens dont le dernier terme est l'usage d'un langage ..." Disponível em: https://fr.wikisource.org/wiki/Esquisse_d'un_tableau_historique_ des_progrès_de_l'esprit_humain. Consulta em: 02 jan. 2017.

7 "Desde a época em que, na Grécia, a escrita alfabética foi conhecida, a história se liga ao nosso século, ao estado atual da espécie humana nos países os mais esclarecidos da Europa, por uma sequência ininterrupta de fatos e de observações; e o quadro da marcha e dos progressos do espírito humano tornou-se verdadeiramente histórico" (CONDORCET, 2009, p. 25).

8 Obviamente, o vocabulário da época não permitia modificações radicais nas referências sem que houvesse uma preocupação constante com isso, ainda que essa fosse a proposta. Assim, em Pensamento Selvagem (LEVI-STRAUSS, 1962, p. 9), o autor deixa escapar a expressão une population arriérée des îles Ryukyu ['uma população atrasada das ilhas Ryukyu'].

${ }^{9}$ Ferreira Netto (2001).

10 "Para tratar certas sociedades como "etapas" do desenvolvimento de outras, seria preciso admitir que, enquanto para estas últimas acontecia alguma coisa, para as outras nada acontecia - ou poucas coisas. E, com efeito, fala-se facilmente dos "povos sem história" (para dizer às vezes que são os mais felizes). Esta fórmula elíptica significa apenas que sua história é e permanecerá desconhecida, não que ela não exista. Durante dezenas e mesmo centenas de milhares de 
anos, lá também, houve homens que amaram, odiaram, sofreram, inventaram, combateram. Na verdade, não existem povos infantes; todos são adultos, mesmo os que não mantiveram diário de sua infância e adolescência." (p. 340)

11 "El primer resultado obtenido por el empleo de las conexiones en la colocación de las masas para formar una distribución general es que las dos extremidades del orden deben ofrecer los seres más desemejantes, porque son lo más alejados. De ello se sigue que, si una de las extremidades del orden presenta los cuerpos vivientes más perfectos, aquellos cuya organización es más compuesta, la otra extremidad del mismo orden deberá necesariamente ofrecer los cuerpos vivientes más imperfectos, es decir, aquellos cuya organización es más simple". (LAMARCK, 1986, p. 93)

${ }^{12}$ As línguas que, como o sânscrito, tecem na própria unidade da palavra sua relação com a frase, analisam-na naquelas partes em que, por sua própria natureza, a frase se apresenta ao entendimento; e, partindo delas constroem sua unidade. As línguas que, como o chinês, encerram cada raiz rígida e inalteradamente no âmbito da palavra fazem, de certa maneira, a mesma coisa e talvez num sentido ainda mais estrito, uma vez que suas palavras estão totalmente isoladas; no entanto, na construção da unidade frasal, estas línguas só vêm em auxílio do entendimento por meios mudos como a colocação das palavras, ou ainda por meio de outras palavras igualmente isoladas. Existe também, se se reúnem as duas formas anteriores, uma segunda alternativa que se opõe a ambas, mesmo que, note-se, seria preferível considerá-la como uma terceira possibilidade, a de reter a unidade da frase para a compreensão, isto é, considerar a frase em todas as suas partes necessárias, e não como um todo composto de palavras, mas sim como uma verdadeira palavra única. (HUMBOLDT, 1990, p. 185; tradução minha da tradução espanhola).

${ }^{13} \mathrm{Si}$ nos aventuramos a descender a los orígenes primeros dele lenguaje, habremos de conceder que el hombre siempre vincula a cualquier sonido que emite como lenguaje un sentido 
interior completo, una frase concluida; no tiene la intención de poner ahí una palabra aislada, por más que a nuestro modo de ver su expresión sólo contenga eso en ocasiones. Esto no nos autoriza, sin embargo, a imaginar la relación originaria de la frase con las palabras como si una frase de suyo completa y expresa fuese sólo más tarde analizada en palabras por vía de abstracción. Si, como es lo más natural, imaginamos la formación de la lengua como algo progresivo, tendremos que suponer que, al igual que cualquier otra cosa nacida en la naturaleza, se subyace un sistema evolutivo. [...] Lo que distingue a la lengua mexicana es que lo que en los orígenes primeros era el brote aún cerrado y sin desarrollar, en esta lengua aparece como un todo conexo, complexo e indivisible. El chino, por el contrario, confía al oyente el descubrimiento de una trabazón apenas indicada por sonido alguno, en tanto que el sánscrito, con la superior vivez y audacia que le es propia, pone ante sus ojos cada parte en su relación con el todo, indicando ésta mediante una designación fija. (HUMBOLDT, 1990, p. 191-193).

14 Comte (1978, p. 3).

15 Tradução minha. No original: "Enfin, dans l'état positif, l'sprit humain reconnaissent l'impossibilité d'obtenir des notions absolues, renonce à chercher l'origine et la destination de l'univers, et à connaître les causes intimes des phénomènes, pour s'attacher uniquement à décuvrir, par l'usage bien combiné du raisonnement et del'observation, c'est-à-dire leurs relation invariables de succession et de similitude. L'explication des faits, réduite alors à ses termes réels, n'est plus désormais que la liaison établie entre les divers phénomènes particuliers et quelques faits généraux, dont les progrès de la science tendent de plus en plus à diminuer le nombre." (COMTE, 1830, p. 4-5)

16 Spencer (1939, p. 15).

${ }^{17}$ Spencer (1939, p. 30). 
18 “...o movimento do pensamento superior, até o ponto em que pudemos acompanhá-lo, processou-se, em geral, a partir da magia, passando pela religião e chegando à ciência." (FRAZER, 1982, p. 248)

${ }^{19}$ Gellner (2001, p. 132). No original: "The evolutionary aspect of Darwinism, the stress on continuity of development, made it at the very least plausible to suspect that surviving pre-literate peoples might illustrate the condition of primitive peoples of the past, whose social organisation was otherwise barely accessible. The hope of establishing an evolutionary account of human development was tempting, and of course it would have philosophical and political implications: the pattern of evolution would provide a charter for power ranking in a world pervaded by a new type of empire, territorially discontinuous, where the power-holders seemed to be at a different 'stage' of social development from those they ruled." (GELLNER, 2004, p. 114)

${ }^{20}$ Durkheim (2014), p. 13, grifos do autor.

21 Durkheim (2014, p. 15) disse, logo no início do segundo capítulo, intitulado "Regras relativas à observação dos fatos sociais" como epígrafe do texto: "A primeira regra e a mais fundamental é considerar os fatos sociais como coisas".

22 "O que dá força aos estados coletivos não é apenas o fato de serem comuns à geração presente, mas sobretudo o de serem, em sua maioria, um legado das gerações anteriores. De fato, a consciência comum só se constitui muito lentamente e se modifica no mesmo ritmo. É necessário algum tempo para que uma forma de conduta ou uma crença chegue a esse grau de generalidade e de cristalização, algum tempo também para que o perca. Portanto ela é quase toda um produto do passado. Ora, o que vem do passado é, em geral, objeto de um respeito todo particular. Uma prática a que todo o mundo se conforma unanimemente possui, sem dúvida, um grande prestígio; mas se, além disso, conta com o assentimento dos ancestrais, ousa-se ainda menos esquivar-se dela. Assim, a autoridade da 


\section{Notas}

consciência coletiva é constituída em grande parte da autoridade da tradição". (DURKHEIM, 1999, p. 293).

${ }^{23}$ Durkheim (1999, p. 179).

24 "Quanto mais o sistema alveolar é desenvolvido, mais as relações em que cada um de nós está comprometido se encerram nos limites do alvéolo a que pertencemos. Há como que vazios morais entre os diversos segmentos. Ao contrário, esses vazios se preencher à medida que esse sistema se nivela. A vida social, em vez de se concentrar numa multidão de pequenos focos distintos e semelhantes, se generaliza. As relações sociais - diríamos mais exatamente intrassociais se tornam, por conseguintes mais numerosas, pois se estendem, de todos os lados, além de seus limites primitivos". (DURKHEIM, 1999, p. 252).

25 Essa é a posição de Lévi-Strauss (1976, p. 334) quando afirmou que "a humanidade cessa nas fronteiras da tribo, do grupo linguístico, às vezes mesmo da aldeia; a tal ponto, que um grande número de populações ditas primitivas se autodesigna com um nome que significa "os homens" (ou às vezes - digamo-lo com mais discrição? - os "bons", os "excelentes", os "completos"), implicando assim que as outras tribos, grupos ou aldeias não participam das virtudes ou mesmo da natureza humana, mas são, quando muito, chamados de "maus", de "malvados", "de macacos da terra" ou de "ovos de piolho".

26 "O trabalho não se divide entre indivíduos independentes e já diferenciados, que se reúnem e se associam para porem em comum suas diferentes aptidões. Porque seria um milagre que diferenças nascidas assim, ao acaso das circunstâncias, possam se ajustar tão exatamente de modo a formar um todo coerente. Longe de precederem a vida coletiva, dela derivam. Elas só se podem produzir no âmbito de uma sociedade e sob a pressão de sentimento e necessidades sociais; é o que faz serem essencialmente harmoniosas. Portanto, há uma vida social fora de toda divisão do trabalho, que esta supõe. De fato, foi o que estabelecemos diretamente ao mostrar que há sociedades cuja 
coesão deve-se essencialmente à comunidade de crenças e dos sentimentos, e que foi dessas sociedades que saíram aquelas cuja unidade é assegurada pela divisão do trabalho. (DURKHEIM, 1999, p. 276-277).

${ }^{27}$ Comte (1839, p. 597-598, tradução minha).

${ }^{28}$ Velho (2004, p. 16).

29 "Os fatos socais não são o simples desenvolvimento dos fatos psíquicos: os segundos, sim, é que, em grande parte, não são mais que o prolongamento dos primeiros no interior das consciências. [...] Por exemplo, se, como acontece com frequência, se vir na organização da família a expressão logicamente necessária de sentimentos humanos inerentes a toda consciência, inverte-se o a ordem real dos fatos; muito ao contrário, foi a organização social das relações de parentesco que determinou os sentimentos respectivos dos pais e dos filhos. Estes teriam sido bem diferentes se a estrutura social tivesse sido diferente, e a prova disso é que, de fato, o amor paterno é desconhecido numa multidão de sociedades." (DURKHEIM, 1999, p. 363).

${ }^{30}$ Cf. Geertz (1989, p. 107).

${ }^{31}$ Durkheim (1999, p. 348).

32 Durkheim (1999, p. 348).

${ }^{33}$ Durkheim (1999, p. 350).

34 Durkheim (1999, p. 360).

35 Durkheim (1999, p. 360).

${ }^{36}$ Segundo Ernout e Meillet (1979), o termo latino "modernus", que deu origem ao português "moderno" teria sua origem no baixo latim. Formou-se a partir da adjetivação do adverbio "modo" 'recentemente', por analogia a "hodiernus", "aeternus", dentre outros. Durkheim utilizou a expressão "sociétés modernes" uma única vez (p. 28 do original francês, e p. XXVI, da tradução) no Prefácio que escreveu à segunda edição de seu livro. Trata-se, portanto, de uma posição adotada a posteriori 
em relação à sua tipologia social. No entanto, por se tratar de uma releitura de sua própria obra, mostra que o autor interpretou os dados referentes às sociedades tradicionais do ponto de vista de sua própria sociedade, que, para ele, seria moderna. Ressalto ainda que o autor não usou a expressão "sociétés traditionnelles", ou outra semelhante, mas fez inúmeras referências às tradições como característica das sociedades formadas por similitude, nos três tomos de sua exposição teórica, como a transmissão de conhecimento dos mais velhos para os mais novos.

37 "Acabamos de mostrar que os progressos da divisão do trabalho devem-se à mais forte pressão exercida pelas unidades sociais umas sobre as outras e que as obriga a se desenvolverem em sentidos cada vez mais divergentes. Mas essa pressão é neutralizada a cada instante por uma pressão em sentido contrário, que a consciência comum exerce sobre cada consciência particular. Entanto uma nos impele a criar uma nossa personalidade distinta, a outra, ao contrário, obriga-nos a nos parecer com todos os outros. Enquanto a primeira nos inclina a seguir as propensões de nossa natureza pessoal, a segunda nos retém e nos impede de nos desviarmos do tipo coletivo. (DURKHEIM, 1999, p. 283-284)

38 Junqueira (2008).

${ }^{39}$ Disponível em:

http://portalfat.mte.gov.br/wp-content/uploads/2016/02/C B02002_LISTA.pdf Consulta em: 19 ago. 2016.

${ }^{40}$ Durkheim (1999. p. 296-297).

${ }^{41}$ Eldredge e Gold (1972).

42 Sobre isso, já escrevi alhures em Ferreira Netto (1993).

${ }^{43}$ Recentemente, em relação a esse desaparecimento, algumas antigas sociedades começam a reaparecer, mostrando que, apesar de tudo, houve resistência cultural. Em Oliveira (1999), há vários relatos que descrevem a situação atual de sociedades como a dos Tapeba, dos Atikum-Umã, dos Tremembé, dos 
Xucuru-Kariri, dentre outros, passando por um processo de retomada pública de suas identidades étnicas em relação à população que habita seu entorno e em relação à população nacional. Ainda que tenham passado por mudanças culturais profundas, tais sociedades permanecem formadas por solidariedade mecânica.

${ }^{44}$ No original: "An ideia may become effective whenever the ethnic conditions are favorable to its adoption and development" (BOAS, 1911, p. 802).

${ }^{45}$ Canclini (2003, p. XIX).

46 Durkheim (1999, p. 294).

47 Prado Jr. (1963, p. 194).

48 Morse (1970, p. 238).

${ }^{49}$ Morse (1970, p. 238).

${ }^{50}$ Scantimburgo (2006, p. 565).

${ }^{51}$ Scantimburgo (2006, p. 270).

52 Morse (1970, p. 239).

53 Prado Jr. (1966, p. 191).

${ }^{54}$ A respeito dessa mudança nas relações de trabalho da zona rural paulista, da escravidão de negros e índios para o trabalho assalariado de imigrantes, cf. o trabalho de Lara (1998) e as referências que ela indica.

55 Dean (1971, p. 60).

56 Dean (1971, p. 164).

57 O autor refere nessa passagem a obra de Aziz Simão, Sindicato e estado, p. 65-76.

${ }^{58}$ Linhares (1977).

${ }^{59}$ Gellner (1993). 
60 "Recapitulemos as características gerais e centrais da sociedade industrial. Entre os seus pré-requisitos funcionais encontram-se a alfabetização universal e um elevado grau de sofisticação numérica, técnica e geral. Os seus membros são e devem ser móveis e possuir esse treino genérico que lhes possibilite seguir os manuais e as instruções de uma nova actividade ou ocupação. [...] Devem também ser capazes de comunicar através de mensagens escritas, impessoais, descontextualizadas, destinadas àqueles a quem são dirigidas. Assim, estas mensagens devem ser transmitidas no mesmo meio de comunicação linguístico e gráfico comum e standardizado. 0 sistema educacional que assegura este feito desenvolve-se e torna-se indispensável, mas deixa, ao mesmo tempo, de deter o monopólio do acesso à palavra escrita: a clientela é coextensiva à sociedade em geral e a possibilidade de substituição de indivíduos dentro do sistema por outros diz respeito ao sistema educacional, tanto ou mais que a qualquer outro segmento da sociedade." (GELLNER, 1993, p. 60)

61 Dean (1971, p. 76).

62 Durkheim (1999, p. 391-394).

${ }^{63}$ Durkheim (1999, p. 395).

64 “É verdade que essa espontaneidade perfeita não é encontrada em parte alguma como fato realizado. Não há sociedade em que ela ser pura." (DURKHEIM, 1999, p. 396)

65 Para um maior detalhamento a respeito das narrativas do saci, consultar Vieira e Ferreira Netto (2008) e Vieira (2009).

${ }^{66}$ Simmel (2006, p. 42).

${ }^{67}$ Simmel (2006, p. 40).

${ }^{68}$ Simmel (2006, p. 43).

${ }^{69}$ Costa (1983, p. 45).

${ }^{70}$ Costa (1983, p. 58).

${ }^{71}$ Ferreira Netto (2012, p. 20). 
72 Paine (2005, p. 45); grifo meu. No original: "IN the following pages I offer nothing more than simple facts, plain arguments, and common sense" (PAINE, 2016)

73 Paine (2005, p. 47). No original: "To examine that connexion and dependance, on the principles of nature and common sense". (PAINE, 2016).

74 Paine (2005, p. 69-70); grifo meu. No original: "Some, perhaps, will say, that after we have made it up with Britain, she will protect us. Can we be so unwise as to mean, that she shall keep a navy in our harbours for that purpose? Common sense will tell us, that the power which hath endeavoured to subdue us, is of all others, the most improper to defend us". (PAINE, 2016)

75 Popper (1974, p. 31).

76 Popper (1974, p. 307).

77 Popper (1974, p. 33).

78 Popper (1974, p. 33).

79 Cf. Viana (2008), para um maior detalhamento dessa discussão.

800 autor cita Murdock (1932): "Os antropólogos sabem de fato o que é cultura, mas divergem na maneira de exteriorizar este conhecimento" (LARAIA, 2004, p. 63).

${ }^{81}$ No original: "Cultures are systems (of socially transmitted behavior patterns) that serve to relate human communities to their ecological settings. These ways-of-life-of-communities include technologies and modes of economic organization, settlement patterns, modes of social grouping and political organization, religious beliefs and practices, and so on". (KEESING, 1974, p. 75, apud LARAIA, 2004, p. 59)

82 Keesing, 1974. Trad. em Laraia, 2004. No original: "culture is best seen not as complexes of concrete behavior patterns customs, usages, traditions, habit clusters - but as a set of control mechanisms (what computer engineers call 
'programs') - for the gorverning of behavior" (GEERTZ, 1965, apud KEESING, 1974, p. 87. Esse trecho, citado por Keesing, aparece na página 56 da tradução em português publicada pela editora Guanabara, sem data, e na página 32 da tradução publicada pela LTC, em 2008).

83 Para uma discussão mais aprofundada, ver o próprio Keesing (1974).

84 Barley (1983).

${ }^{85}$ No original: 'You recall the stone you showed me?'

'Yes.'

'I asked you if it was from the land of the white men.'

'Yes.'

'Is it the same as this one?' I handed him the marble. With a gasp he examined it against the light.

'It is the same. The clouds in it are darker.'

'Would this stone cause rain?'

He regarded me with amazement. 'How can I know? I would have to try it, to see if it would work. I cannot tell you until I have seen it'. (BARLEY, 1983).

${ }^{86}$ Heller (1977, p. 317), grifos da autora; tradução minha da versão espanhola.

87 "De fato, a força dos vínculos sociais que têm essa origem [a solidariedade mecânica] varia em função das três condições seguintes:

1a A relação entre o volume da consciência comum e o da consciência individual. Sua energia é tanto maior quanto mais completamente a primeira se sobrepõe à segunda.

2 ${ }^{\text {a }}$ A intensidade média dos estados da consciência coletiva. Supondo-se igual, a relação dos volumes, a consciência coletiva age tanto mais sobre o indivíduo quanto maior for a sua vitalidade. Se, ao contrário, for constituída apenas de impulsos fracos, ela o arrasta fracamente para o sentido coletivo. Portanto, o indivíduo terá tanto maior facilidade para seguir seu sentido próprio, e a solidariedade será menos forte. 
$3^{\text {a }}$ A determinação maior ou menor desses mesmos estados. Com efeito, quanto mais definidas as crenças e as práticas, menos elas deixam espaço para as divergências individuais. Elas são moldes uniformes em que vazamos todos, uniformemente, nossas ideias e nossas ações. Portanto, o consenso é tão perfeito quanto possível; todas as consciências vibram em uníssono. Inversamente, quanto mais as regras de conduta e as regras do pensamento são gerais e indeterminadas, mais a reflexão individual deve intervir para aplicá-las aos casos particulares. Ora, ela não pode despertar sem que as dissidências se manifestem, porque, como varia de um homem a outro em qualidade e quantidade, tudo o que ela produz tem o mesmo caráter. As tendências centrífugas vão se multiplicando, pois, à custa da coesão social e da harmonia dos movimentos". (DURKHEIM, 1999, p. 133)

88 Peirce (1975, p. 81).

89 "O que dá força aos estados coletivos não é apenas o fato de serem comuns à geração presente, mas sobretudo o de serem, em sua maioria, um legado das gerações anteriores. [...] Ora, o que vem do passado é, em geral, objeto de um respeito todo particular. Uma prática a que todo o mundo se conforma unanimemente possui, sem dúvida, um grande prestígio; mas se, além disso, conta com o assentimento dos ancestrais, ousa-se ainda menos esquivar-se dela. Assim, a autoridade da consciência coletiva é constituída em grande parte da autoridade da tradição". (DURKHEIM, 1999, p. 293).

90 Vasconcellos (1986); Vieira (2009).

${ }^{91}$ Cf. Popper (1974).

92 Durkheim (1999, p. 179-180).

93 Ferreira Netto (2008).

${ }^{94}$ Hallbwachs (2006).

95 Rosenfield (1994). 
96 Por amor à simplicidade, considerei a relação entre os cônjuges da família elementar e a dos anciãos como de consanguinidade.

97 Junqueira (2008).

98 Fausto (1995).

${ }^{99}$ Wagley; Galvão (1946). Essa não parece ser uma posição unânime entre os antropólogos. Para uma discussão mais detalhada, ver Laraia (1971) e, mais recentemente, Baleé (2014). Alguns autores optam pela classificação dravidiana para grupos tupi-guarani, como o faz Fausto (1995) para o grupo parakanã.

100 "Um grupo de siblings é constituído pelos filhos e filhas de um homem e sua esposa numa sociedade monogâmica, de um homem e suas esposas, onde houver poligamia, ou de uma mulher e seus maridos, em comunidades poliândricas." (RADCLIFFE-BROWN, 1969, p. 65)

101 Radcliffe-Brown (1969, p. 67).

102 Ladeira (2007).

${ }^{103}$ Dean (1971, p. 81-82).

104 Fragmento transcrito de Narrativa Tenharim, coletada por Cristina de Cássia Borella e por mim, em fevereiro/95.

105 Agostinho (1974, p. 107).

106 Agostinho (1974, p. 108).

107 Tradução minha. No original espanhol: "El inconsciente étnico de un individuo es aquella parte de su inconsciente total que posee en común con la mayoría de los miembros de su cultura. Lo compone todo lo que, conforme las exigencias fundamentales de su cultura, cada generación aprende por sí misma a reprimir y luego, a su vez, obliga a la generación siguiente a reprimir." (DEVEREUX, 1973, p. 28)

${ }^{108}$ Geertz (1989, p. 93-94). 
109 Geertz (1989, p. 107).

${ }^{110}$ Luna (2002, p. 258).

111 Tubert (1996, p. 73).

112 “Nas situações humanas, isto é, culturais, o 'stress' será traumatizando somente se for atípico ou se, mesmo atípico por sua natureza, for muito intenso ou até prematuro. Um 'stress' é atípico se a cultura não dispõe de nenhuma defesa preestabelecida, 'produzida em série', suscetível de atenuar ou amortecer o choque. Assim, é mais provável que a perda de um filho na guerra traumatizará muito mais a uma mãe ateniense do que a uma mãe espartana, pois esta última foi condicionada por sua cultura para obter glória e consolo do sacrifício de um filho pela cidade. Entretanto, um 'stress' normal pode ser fonte de traumatismo se se reveste de uma intensidade particular: uma coisa é um pai perder um filho no combate e outra é perder, como Príamo, a quase totalidade de seus cinquenta filhos [...]. Por último, um estado de 'stress' é traumatizante quando ocorre prematuramente, ou seja, quando chega a um indivíduo que não tem acesso às defesas culturais apropriadas. Uma variante importante desse tipo de situação é a das classes desfavorecidas, a quem se nega sistematicamente o acesso às defesas que a cultura reserva apenas aos privilegiados". (DEVEREUX, 1973, p. 32, tradução minha da versão espanhola).

113 No original: "En la ilustración, la maternidad espiritual y la carnal parecen aproximarse, comenzando a formularse un modelo terrenal de la "buena madre", siempre sumisa al padre, pero valorizada por la crianza de los hijos. La salud del cuerpo comenzó a ser tan importante como la salud espiritual, y comienza a construirse la idea del amor maternal como un elemento indispensable para el recién nacido y se va perfilando como un valor de la civilización al mismo tiempo que como código de buena conducta. La relación afectiva suple ahora la función nutricia y tiñe toda la función educativa; vemos así que en esta época la función materna absorbe la individualidad de la mujer, al mismo tiempo que se perfila la 
separación de los roles de la madre y del padre en relación con las tareas de educación y manutención de la prole." (VEREA, 2005, p. 41)

114 Tradução minha. No original: "Socialmente se ha exagerado el papel de la mujer madre, y en cuanto a su relación con el hijo no parece ser cierto que las mujeres tengan desarrollado el "instinto" o necesidad maternal. Prueba de ello es que, desde siempre, han buscado la manera de evitar embarazos, un hecho detectado en las distintas civilizaciones de la humanidad. Todo lo cual demuestra que esa imagen santificada de la mujer como madre no resulta muy auténtica. Ese ídolo falso no puede perdurar y continuar subestimando a las mujeres como personas, sacralizando lo puramente biológico, lo que no la diferencia de ningún otro mamífero hembra, lo que no constituye muchas veces más que un accidente inesperado y una limitación". (PEREZ, 2008, p. 97-98)

115 Silva (1977); Junqueira (1978); Mindlin (1985).

116 Collas et al. (1994); Baldin e Nogueira (1998); Prietsch et al. (2011).

${ }^{117}$ Azevedo e Arrais (2006).

118 Luna (2002).

${ }^{119}$ Anchieta (1933, p. 217-219).

${ }^{120} \mathrm{Em}:$

http://www.academia.org.br/academicos/coelho-neto/texto s-escolhidos. Consulta em: 18 dez. 2016.

${ }^{121}$ Devereux (1973).

${ }^{122} \mathrm{Em}$

http://legis.senado.leg.br/legislacao/ListaTextoIntegral.actio n?id=50260\&norma=66049. Consulta em: 12 dez. 2016.

${ }^{123}$ Coralina (2001, p. 190-191).

124 Andrade, Prefácio Interessantíssimo. In: . Pauliceia Desvairada. 
125 Halbwacks (1990); Ferreira Netto (2008).

126 Heller (1977, p. 321).

127 Heller (1977, p. 322).

128 Fiorin (2009, p. 117).

${ }^{129}$ Gellner (1993, p. 78).

130 Andrade (2006, p. 11).

131 Andrade (2006, p. 13).

132 Andrade (2006, p. 15).

133 Uma descrição detalhada da proposta de Frege para a noção de símbolo será feita no próximo capítulo.

134 Benveniste (1976, p. 278).

135 Austin (1990, p. 27).

136 Rorty (2005, p. 121).

137 Benveniste (1976, p. 301).

138 "La segunda es la que se deduce de la causa eficiente. Pues nos encontramos que en el mundo sensible hay un orden de causas eficientes. Sin embargo, no encontramos, ni es posible, que algo sea causa eficiente de sí mismo, pues sería anterior a sí mismo, cosa imposible. En las causas eficientes no es posible proceder indefinidamente porque en todas las causas eficientes hay orden: la primera es causa de la intermedia; y ésta, sea una o múltiple, lo es de la última. Puesto que, si se quita la causa, desaparece el efecto, si en el orden de las causas eficientes no existiera la primera, no se daría tampoco ni la última ni la intermedia. Si en las causas eficientes llevásemos hasta el infinito este proceder, no existiría la primera causa eficiente; en consecuencia no habría efecto último ni causa intermedia; y esto es absolutamente falso. Por lo tanto, es necesario admitir una causa eficiente primera. Todos la llaman Dios." (AQUINO, 2001, p. 112)

139 Brasil (1988). 
140 Tradução minha. No original: “[...] la tierra fue creada de esta manera: dos dioes, Quetzacóatl y Tezcatlipoca, bajaron la diosa de la tierra del cielo. Ella tenía las articulaciones completamente llenas de ojos y bocas, con las cuales ella mordía como una bestia salvaje. Antes de que la bajaran ya había agua, de la cual nadie sabe quién la creó, sobre la cual esta diosa caminaba. Viento esto los dioses dijeron el uno al otro: "Es necesario hacer la tierra", y diciendo esto se convirtieron ambos dos en grandes serpientes las cuales agarraron a la diosa la una en la mano derecha y en el pie izquierdo, la otra en la mano izquierda y el pie derecho, y la jalaran tanto que la hicieron romperse por la mitad. De la mitad detrás de los hombros hicieron la tierra, y la otra mitad la llevaron al cielo. Por eso se enojaron mucho los otros dioses. Para recompensar a la dicha diosa de la tierra por el daño que los dos dioses le habían hecho, todos los dioses descendieron del cielo para consolarla y ordenaron que de ella salieron todos los frutos necesarios para la vida de los hombres. Por eso hicieron de sus cabellos árboles, flores, y hierbas, de su piel las hierbas muy pequeñas ya las pequeñas flores, de los ojos pozos, fuentes y pequeñas cavernas, de la boca ríos y grandes cavernas de los agujeros de la nariz valles de montañas, y de los hombros montañas. Y esta diosa lloraba algunas veces durante la noche queriendo comer corazones de hombres y no se quería callar hasta que se lo daban, y no queriendo llevar fruta si no estaba rociada con sangre humana". (KUCKERBERG, 1999, p. 22)

141 No original: "Los dioses dijeron entre sí: "Los hombres siempre serán tristes, si no hacemos alguna cosa para alegrarlos y para que ellos tengan placer de vivir en la tierra y para que nos alaben, canten y bailen". Esto fue oído por el dios del viento (=Quetzalcóatl), y pensaba en su corazón dónde podría encontrar alguna bebida para alegrar a los hombres y hacerles un regalo. Pensándolo, le vino a la mente una diosa virgen, llamada Mayahuel a la cual guardaba una diosa, su abuela, llamada Tzitzímitl. Inmediatamente se fue hacia ella, las cuales se encontraban dormidas y despertó a la virgen y le 
dijo: "Vengo a traerte para llevarte al mundo". Ella estuvo inmediatamente de acuerdo y así descendieron ambos dos [del cielo], levándola él en sus hombros. Luego que ellos llegaron a la tierra los dos se cambiaron en un árbol el cual tenía dos ramas de las cuales una se llamaba "sauce de quetzal", que era la del dios del viento y la otra "árbol de flores" que era la de la virgen. Cuando la abuela que dormía se despertó y no encontró a su nieta llamó luego a las otras diosas llamadas también Tzitzímitl y todas descendieron a la tierra buscando al dios del viento. En este momento las dos ramas del árbol se rompieron, y la de la virgen fue reconocida luego por la diosa vieja la cual la tomó y la rompió dando a cada una de las otras diosas un pedazo, que ellas comieron. Pero la rama del dios del viento no la rompieron sino la dejaron allá; tan pronto como las diosas habían subido al cielo, se tornó a su primera forma de dios del viento, el cual recogió los huesos de la virgen que las diosas habian comido, y los enterró. De ellos salió una planta que llaman metl [agave], de la cual los indios hacen el vino que beben y con el cual se emborrachan". (KUCKERBERG, 1999, p. 27-28)

142 "Recebi de Dyuasá, além disso, textos originais em karajá. Eles têm forma fixa. Quando pedi a Dyuasá que os repetisse, falou sempre em ordem. Ainda que não soubesse ler, conhecia o significado de uma palavra no meio do texto escrito por mim, quando contava as palavras desde o começo. Os textos representam um esqueleto do mito em poucas palavras e talvez sirvam de apoio ao narrador, passando, desta forma, de geração a geração." (BALDUS, 1979, p. 109)

143 Tradução minha da tradução espanhola. No original espanhol: “... el desligar el alma, según afirmamos, es la aspiración suma, constante y propia tan solo de los que filosofan en recto sentido de la palabra; y la ocupación de los filósofos estriba precisamente en eso mismo, en el desligamiento y separación del alma y del cuerpo. [...] Luego [...] los que filosofan en el recto sentido de la palabra se ejercitan en morir, y son los hombres a quienes resuelta menos temeroso el estar muertos." (PLATÃO, 1981, p. 617-618) 


\section{Notas}

144 Tradução minha da tradução espanhola. No original espanhol: “¿tienen una existencia en el Hades las almas de los finados, o no? Pues, existe una antigua tradición, que hemos mencionado, que dice que, llegadas de este mundo al otro las almas, existen allí y de nuevo vuelven acá, naciendo de los muertos [...] y la prueba suficiente de que esto es verdad seria el demonstrar de una manera evidente que los vivos no tienen otro origen que los muertos." (PLATÃO, 1981, p. 618)

145 Platão (1981, p. 620-621).

146 Tradução minha da tradução espanhola. No original espanhol: "Luego convenimos aqui también que los vivos proceden de los muertos no menos que los muertos de los vivos $\mathrm{y}$, siendo esto así, parece que hay indicio suficiente de que es necesario que las almas de los muertos existan en alguna parte, de donde vuelvan a la vida." (PLATÃO, 1981, p. 621)

${ }^{147}$ Nimuendaju (1987); Cadogan (1949a); Schaden (1974).

148 Cadogan (1949b).

149 Tradução minha da tradução espanhola. No original espanhol: "Así, no es más necesario preguntar se el alma y el cuerpo son uno, que preguntar se la cera y la impresión que se marca en ella son una cosa, o bien, en general, preguntar se la materia de cada cosa es lo mismo de que ella es materia." (ARISTÓTELES, 1982, p. 141)

150 Tradução minha da tradução espanhola. No original espanhol: "Supongamos que un instrumento o herramienta, un hacha, por ejemplo, fuera un cuerpo natural; la substancia del hacha será aquello que hace de este instrumento un hacha y ella sería su alma; supóngase que este alma se separe de ella; el instrumento no será ya un hacha a no ser en un sentido equívoco. [...] Si los ojos fueran un ser vivo, su alma seria su visión porque esta é la substancia bajo la acepción de forma, y si falta la visión, no hay ojo algún de no ser en un sentido equívoco como, por ejemplo, un ojo de piedra o un ojo pintado." (ARISTÓTELES, 1982, p. 141-142) 
151 Aristóteles (1982, p. 145).

${ }^{152}$ Aristóteles (1982, p. 145).

153 Tradução minha da tradução espanhola. No original espanhol: "Hemos de entender, de una manera general y respecto de toda sensación, que el sentido es lo que recibe a forma de los objetos sensibles sin recibir la materia, igual que la cera recibe la impresión del sello de un anillo sin el hierro y el oro, y recibe la impresión de oro o de bronce, pero no en cuanto oro o bronce; si, en todo caso, el sentido es afectado por lo que tiene color, sabor, sonido, pero no en cuanto cada uno de estos objetos es una cosa particular, sino en cuanto es de tal cualidad y en virtud de su forma." (ARISTÓTELES, 1982, p. 178)

154 Berkeley (2010, p. 58). No original "But besides all that endless variety of Ideas or Objects of Knowledge, there is likewise something which knows or perceives them, and exercises divers Operations, as Willing, Imagining, Remembering about them. This perceiving, active Being is what I call Mind, Spirit, Soul or my Self. By which Words I do not denote any one of my Ideas, but a thing intirely distinct from them, wherein they exist, or, which is the same thing, whereby they are perceived; for the Existence of an Idea consists in being perceived." (BERKELEY, 2010, p. 58)

155 Hume (2009, p. 294-295). No original: “... that all the nice and subtile questions concerning personal identity can never possibly be decided, and are to be regarded rather as grammatical than as philosophical difficulties. Identity depends on the relations of ideas; and these relations produce identity, by means of that easy transition they occasion. But as the relations, and the easiness of the transition may diminish by insensible degrees, we have no just standard, by which we can decide any dispute concerning the time, when they acquire or lose a title to the name of identity. All the disputes concerning the identity of connected objects are merely verbal, except so far as the relation of parts gives rise to some fiction or imaginary principle of union." (HUME, 1965, p. 286) 
156 Hume (2009, p. 291). No original: "We now proceed to explain the nature of personal identity [...] And here 'tis evident, the same method of reasoning must be continu'd, which has so successfully explain'd the identity of plants, and animals, and ships, and houses, and of all the compounded and changeable productions either of art or nature. The identity, which we ascribe to the mind of man, is only a fictitious one, and of a like kind with that which we ascribe to vegetables and animal bodies." (HUME, 1965, p. 259)

${ }^{157}$ Hume $(2009$, p. 293). No original: "In this particular, then, the memory not only discovers the identity, but also contributes to its production, by producing the relation of resemblance among the perceptions." (HUME, 1965, p. 261)

${ }^{158}$ Hume (2009, p. 293). No original: “... the human mind, is to consider it as a system of different perceptions or different existences, which are link'd together by the relation of cause and effect, and mutually produce, destroy, influence, and modify each other." (HUME, 1965, p. 261)

159 Hume (2009, p. 293-294). No original: "In this respect, I cannot compare the soul more properly to any thing than to a republic or commonwealth, in which the several members are united by the reciprocal ties of government and subordination, and give rise to other persons, who propagate the same republic in the incessant changes of its parts. And as the same individual republic may not only change its members, but also its laws and constitutions; in like manner the same person may vary his character and disposition, as well as his impressions and ideas, without losing his identity. (HUME, 1965, p. 261)

160 Hume (2009, p. 294), grifos do autor. No original: "...memory does not so much produce as discover personal identity, by shewing us the relation of cause and effect among our different perceptions." (HUME, 1965, p. 262)

${ }^{161}$ Hume (2009, p. 287), todos os grifos são meus. No original: "...the controversy concerning identity is not merely a dispute of words. For when we attribute identity, in an improper sense, 
to variable or interrupted objects, our mistake is not confin'd to the expression, but is commonly attended with a fiction, either of something invariable and uninterrupted, or of something mysterious and inexplicable, or at least with a propensity to such fictions. What will suffice to prove this hypothesis to the satisfaction of every fair enquirer, is to shew from daily experience and observation, that the objects, which are variable or interrupted, and yet are suppos'd to continue the same, are such only as consist of a succession of parts, connected together by resemblance, contiguity, or causation." (HUME, 1965, p. 255)

162 Wertheimer (1938).

163 Hume (2009, p. 285), grifos do autor. No original: "The mind is a kind of theatre, where several perceptions successively make their appearance; pass, re-pass, glide away, and mingle in an infinite variety of postures and situations. There is properly no simplicity in it at one time, nor identity in different; whatever natural propension we may have to imagine that simplicity and identity." (HUME, 1965, p. 253)

164 Hume $(2009$, p. 285). No original: "The comparison of the theatre must not mislead us. They are the successive perceptions only, that constitute the mind; nor have we the most distant notion of the place, where these scenes are represented, or of the materials, of which it is compos'd." (HUME, 1965, p. 253)

165 Le Breton (2016).

166 Hume (2009, p. 294). No original: "As memory alone acquaints us with the continuance and extent of this succession of perceptions, 'tis to be consider'd, upon that account chiefly, as the source of personal identity. Had we no memory, we never shou'd have any notion of causation, nor consequently of that chain of causes and effects, which constitute our self or person." (HUME, 1965, p. 261-262)

167 Hume (2009, p. 294). No original: "But having once acquired this notion of causation from the memory, we can 
extend the same chain of causes, and consequently the identity of our persons beyond our memory, and can comprehend time and circumstances, and actions, which we have entirely forgot, but suppose in general to have existed." (HUME, 1965, p. 262)

168 No original: "Whatever comes into consciousness, is thought by us, either as belonging to the mental self, exclusively (subjectivo-subjective), or as belonging to the notself, exclusively (objectivo-objective), or as belonging partly to both (subjectivo-objective)." 'Tudo o que entra na consciência é pensado por nós, seja fazendo parte, exclusivamente, do self mental (subjetivo-subjetivo), ou do não-eu, também exclusivamente (objetivo-objetivo) ou, ainda, de ambos (subjetivo-objetivo)'. (HAMILTON, 1861, p. 570 tradução minha.)

169 Tradução minha. No original: "We can distinguish very definitely between the self and the body. The body can be there and can operate in a very intelligent fashion without there being a self involved in the experience. The self has the characteristic that it is an object to itself, and that characteristic distinguishes it from other objects and from the body." (MEAD, 1962, p. 136)

170 Tradução minha. No original: "Such a self is not, I would say, primarily the physiological organism. The physiological organism is essential to it, but we are at least able to think of a self without it. Persons who believe in immortality, or believe in ghosts, or in the possibility of the self leaving the body, assume a self which is quite distinguishable from the body. How successfully they can hold these conceptions is an open question, but we do, as a fact, separate the self and the organism. It is fair to say that the beginning of the self as an object, so far as we can see, is to be found in the experiences of people that lead to the conception of a 'double'." (MEAD, 1962, p. 139-140)

171 Tradução minha. No original: "When one is running to get away from someone who is chasing him, he is entirely occupied in this action, and his experience may be swallowed up in the 
objects about him, so that he has, at the time being, no consciousness of self at all. We must be, of course, very completely occupied to have that take place, but we can, I think, recognize that sort of a possible experience in which the self does not enter." (MEAD, 1962, p. 137)

172 Tradução minha. No original: "The individual experiences himself as such, not directly, but only indirectly, from the particular standpoints of other individual members of the same social group, or from the generalized standpoint of the social group as a whole to which he belongs. For he enters his own experience as a self or individual, not directly or immediately, not by becoming a subject to himself, but only in so far as he first becomes an object to himself just as other individuals are objects to him or in his experience; and he becomes an object to himself only by taking the attitudes of other individuals toward himself within a social environment or context of experience and behavior in which both he and they are involved." (MEAD, 1962, p. 138)

173 Tradução minha. No original: "The importance of what we term "communication" lies in the fact that it provides a form of behavior in which the organism or the individual may become an object to himself. [...] So far as that type of communication is a part of behavior it at least introduces a self. [...] But it is where one does respond to that which he addresses to another and where that response of his own becomes a part of his conduct, where he not only hears himself but responds to himself, talks and replies to himself as truly as the other person replies to him, that we have behavior in which the individuals become objects to themselves." (MEAD, 1962, p. 138-139)

174 Tradução minha. No original: "The self is something which has a development; it is not initially there, at birth, but arises in the process of social experience and activity" (MEAD, 1962, p. 135)

175 Hall (1997/1998, p. 27). No original: "I, then, went through the long, important, political education of discovering that I am 'black'. Constituting oneself as 'black' is another recognition of 
self through difference: certain clear polarities and extremities agains which one tries to define oneself. We constantly underestimate the importance, to certain crucial political things that have happened in the world, of this ability of people to constitute themselves, psychically, in the black identity. It has long been thought that this is really a simple process: a recognition - a resolution of irresolutions, a coming to rest in some place which was always there waiting for one. The 'real me' at last!

The fact is 'black' has never been just there either. It has always been an unstable identity, psychically, culturally and politically. It, too, is a narrative, a story, a history. Something constructed, told, spoken, not simply found. People now speak of the society I come from in totally unrecognizable ways. Of course Jamaica is a black society, they say. In reality it is a society of black and brown people who lived for three or four hundred years without ever being able to speak of themselves as 'black'. 'Black' is an identity which had to be learned and could only be learned in certain moment. In Jamaica that moment is the 1970s." (HALL, 1987, p. 45)

176 Campante et al. (2004, p. 205).

177 Tradução minha. No original: "I know of no other form of behavior than the linguistic in which the individual is an object to himself, and, so far as I can see, the individual is not a self in the reflexive sense unless he is an object to himself. It is this fact that gives a critical importance to communication, since this is a type of behavior in which the individual does so respond to himself." (MEAD, 1962, p. 142)

178 Benveniste (1976, p. 286).

179 Shannon e Weaver (1947).

180 Benveniste (1989).

181 Greimas e Courtés (s.d.).

182 [...] identifica-se a instância da narrativa com a instãncia de "escrita", o narrador com o autor e o destinatário da narrativa 
com o leitor da obra. Confusão talvez legítima no caso de uma narrativa autobiográfica real, mas não quando se trata de uma narrativa de ficção, onde o próprio narrado é um papel fictício, ainda que directamente assumido pelo autor, e onde a situação narrativa suposta pode ester diferenciada do acto de escrita (ou de ditado) que se lhe refere [...]. (GENETTE, 1979, p. 213)

183 Goffman (1998, p. 87). No original: "It is necessary to look at the remaining element of the conversational paradigm, the notion of speaker. / In canonical talk, one of the two participants moves his lips up and down to the accompaniment of his own faces (and sometimes bodily) gesticulations, and words can be heard issuing from the locus of his mouth. His is the sounding box in use, albeit in some actual cases he can share this physical function with a loudspeaker system or a telephone. In short, he is the talking machine, a body engaged in acoustic activity, or, if you will, an individual active in the role of utterance production. $\mathrm{He}$ is functioning as an 'animator'." (GOFFMAN, 1981, p. 144)

184 Goffman (1998, p. 87). No original: "Sometimes one has in mind that there is an 'author' of the words that are heard, that is, someone who has selected the sentiments that are being expressed and the words in which they are encoded. / Sometimes one has in mind that a 'principal' (in the legalist term) is involved, that is, someone whose position is stablished by the words that are spoken, someone whose beliefs have been told, someone who is committed to what the words say. Note that on deals in this case not so much with a body or mind as with a person active in some particular social identity or role, some special capacity as a member of a group, office, category, relationship, association, or whatever, some socially based source of self-identification." (GOFFMAN, 1981, p. 144-145)

185 Austin (1990, p. 143-144).

1860 termo "locutor" tem atualmente uma aplicação extensa nos estudos da linguagem, o que provoca grande ambiguidade. Essa diversidade de usos pode ser vista em Charaudeau e 
Mainguenau (2004), no seu verbete. Estamos aqui utilizando o termo baseados na definição de Ferreira (1986): "[Do lat. Locutore, 'aquele que fala'] S. m. Profissional encarregado de ler texto, de irradiar ou apresentar programas ao microfone das estações radioemissoras ou televisoras. [Substitui o ingl. Speaker]." A definição proposta vai ao encontro do termo speaker, tal como usado por Goffman, e não envolve a noção de autor, isto é, o locutor pode ser ou não autor de suas falas. Xavier e Mateus (s.d.) dão definição aproximada a essa: "Aquele que emite a mensagem linguística. Os termos locutor e falante aplicam-se sobretudo à comunição oral.” A restrição em relação a seu uso na escrita nos parece uma idiossincrasia desnecessária.

187 Todorov (2013).

188 Moura Neves (1987 p. 83).

189 Moura Neves (1987 p. 84).

190 Todorov (2013, p. 22-23).

191 Rorty (2007, p. 28).

192 Berkeley (2010, p. 58). No original: "By Sight I have the Ideas of Light and Colours with their several Degrees and Variations. By Touch I perceive, for Example, Hard and Soft, Heat and Cold, Motion and Resistance, and of all these more and less either as to Quantity or Degree. Smelling furnishes me with Odors; the Palate with Tastes, and Hearing conveys Sounds to the Mind in all their variety of Tone and Composition. And as several of these are observed to accompany each other, they come to be marked by one Name, and so to be reputed as one Thing. Thus, for Example, a certain Colour, Taste, Smell, Figure and Consistence having been observed to go together, are accounted one distinct Thing, signified by the Name Apple" (BERKELEY, 2002, p. 12).

193 Tradução minha da versão espanhola. No original espanhol: "La designación del concepto por medio del sonido es una conexión de dos cosas cuya naturaliza jamás permitirá una 
unión verdadera. $Y$, sin embargo, el concepto es tan incapaz de librarse de la palabra como lo es el hombre de prescindir de suas rasgos faciales. [...] La unión de esas dos naturalezas diversas que son el concepto y el sonido, incluso olvidando por entero la vibración material de este último y reteniendo sólo la representación, requiere un tercero que haga de mediador entre ambos y en el cual ambos puedan encontrarse." (HUMBOLDT, 1990, p. 132-133).

194 "A forma mais fácil das ideias que são de interesse filosófico é a ideia de um signo ou representação. Um signo representa algo à ideia que se produz ou se modifica. Trata-se de um veículo de transporte na mente de algo que vem de fora. 0 que é representado é chamado de seu objeto ['object']; o que o carrega, seu sentido ['meaning']; e a ideia a que dá lugar, seu interpretante ['interpretant']. 0 objeto da representação pode ser nada mais do que uma representação da qual a primeira representação é o interpretante. Mas uma série sem fim de representações, cada uma representando a representação de trás, pode ser concebida para ter um objeto absoluto em seu limite. 0 significado de uma representação pode não ser nada mais do que uma representação" (PEIRCE, CP 1.339).

195 Charles S. Peirce fazia suas anotações de forma pouco formalizada. Seus escritos foram parcialmente ajuntados por Charles Hartshorne, Paul Weiss nos anos de 1931 a 1935, e completados por Arthur W. Burks, em 1958. Foram divulgados por John Deely em edição eletrônica em 1994. Disponível em http://courses.arch.ntua.gr/fsr/138469/Peirce,\%20Collected $\% 20$ papers.pdf

196 Peirce, CP 1.564.

197 [CP 5.73] Trad. para o português em Peirce (1974, p. 33).

198 Capitu é uma personagem polêmica do romance Dom Casmurro, escrito por Machado de Assis, no final do século XIX. A polêmica decorre da impossibilidade de o leitor confirmar se Capitu traiu seu marido Bentinho, o Dom 
Casmurro, ou se se tratava somente de um ciúme doentio do marido que o fez pensar dessa maneira. No texto, o autor oferece pistas para ambas as interpretações, mas não assegura nenhuma delas. A polêmica em torno dessa personagem chegou a ser objeto de várias discussões acadêmicas. (Cf. artigo de GONÇALVES, 1999, publicado no jornal Folha de S. Paulo de 25 de junho de 1999, além de outros que saíram na mesma edição.)

199 Frege (1978, p. 63).

${ }^{200}$ Frege (1978, p. 62).

${ }^{201}$ Russel (1978).

202 Russel (1978, p. 116).

203 Pavlov (1903, p. 19).

${ }^{204}$ No original: "La réaction salivaire de l'animal pourrait être considérée dans la vie subjective comme le substratum d'une image pure, élémentaire, le substratum de la pensée." (p. 54)

205 CLG, p. 19 da trad.

206 CGL, p. 21 da trad.

207 Cf. p. 80 da trad. No original: "Ces deux èlèments son intimament unis e s'appellent l'un l'autre". CLG, p. 99.

2080 autor se refere à diferença entre a Linguística da Língua e a Linguística da Fala. Cf. p. 28, da trad.

209 Trad. de José Teixeira, em Semiótica... p. 64 §275. No original: "Namely, while no Representamen actually functions as such until it actually determines an Interpretant, yet it becomes a Representamen as soon as it is fully capable of doing this; and its Representative Quality is not necessarily dependent upon its ever actually determining an Interpretant, nor even upon its actually having an Object." (CP 2.275)

210 Tradução minha. No original: "Now the mere visual stimulus of a patch of red light will not cause the withdrawal of the hand. The patch of red light may produce no marked 
reaction whatsoever (what reaction does appear will depend upon previous conditioning). But if I show the red light and then immediately or shortly thereafter stimulate my subject's hand with the electric current and repeat this routine often enough, the red light will cause the immediate withdrawal of the hand. The red light now becomes a substitute stimulus it wil call the $\mathrm{R}$ whenever stimulates the subject in that setting. Something has happened to bring about this change. This change, as we have pointed out, is called conditioning - the reaction remains the same but we have increase the number of stimuli that will call it out. To express the new state of affairs we (rather inaccurately) describe the change by speaking of the stimulus as being 'conditioned'. (WATSON, 1925, p. 21-22)

211 Köhler (1970). No original: "The right psychological formula is therefore: pattern of stimulation-organizationresponse to the products of organization." (p. 165)

212 Estou marcando entre parênteses o que ocorre como lembrança.

${ }^{213}$ Rorty (2007).

214 Tradução minha. No original: "Soon the human has a verbal substitute within himself theoretically for every object in the world. Thereafter he carries the world around with him by means of this organization. An he can manipulate this word world in the primacy of his room or when he lies down in his bed in the dark. Many of our discoveries come largely through this ability to manipulate a world of objects not actually presente to our senses. [...] We carry this world around with us as actual bodily organization, in the muscular and glandular organization of our throat, chest, etc. (including, of course, the sense organs in the muscles and the nervous system). That organization is ready to function day and night whenever the appropriate stimulus is given. What is this appropriete stimulus?" (WATSON, 1925, p. 187).

215 Skinner (1978, p. 114). 
216 Skinner (1978, p. 197). No original: "When the cook announces Dinner!, the listener may respond in two ways. By salivating or by responding otherwise with gland or smooth muscle, he demonstrates Pavlovian conditioning. By going to the table and sitting down, he demonstrates a discriminated operant which has been reinforced upon past occasions of a similar sort." (SKINNER, 1957, p. 160)

217 Chomsky (1959).

218 Mandler (1984, p. 88-89).

${ }^{219}$ Shannon; Weaver (1975, p. 8). No original: "The receiver is a sort of inverse transmitter, changing the transmitted signal back into a message, and banding this message on to the destination." (SHANNON; WEAVER, 1964, p. 7).

${ }^{220}$ Martins (2014, p. 107).

221 Martins (2014, p. 108).

${ }^{222}$ Eco (2004, p. 38).

223 Eco (2004, p. 39).

2240 termo "mensagem" aqui parece ter um sentido diferente daquele que vimos no capítulo anterior. Embora Bourdieu fale várias vezes sobre estilo, nesse texto, podemos entender que o termo foi usado no sentido de interpretante de Peirce, como ficará mais claro adiante.

225 Bourdieu (1996, p. 25).

${ }^{226}$ Bourdieu (1996, p. 25).

227 Bourdieu (1996, p. 37).

228 Merton (1970, 516-517).

${ }^{229}$ Festinger (1975, p. 19).

${ }^{230}$ Festinger (1975, p. 13).

231 Festinger (1975, p. 18).

232 Festinger (1975, p. 19). 
233 Wolf (1992).

234 Propp (2006, p. 20-21).

235 Propp (2006, p. 21).

236 Propp (2006, p. 23).

237 Propp (2006, p. 23).

238 Ferreira Netto (2008, p. 80-81).

239 Tradução minha. No original: "A reportable event is one which justifies the automatic reassignment of speaker role to the narrator." (LABOV, 1997).

240 Galembeck (1995).

241 Ferreira Netto (2008).

242 Tradução minha de Labov (1997). No original: “An orientation clause gives information on the time, place of the events of a narrative, the identities of the participants and their initial behavior."

243 Tradução minha. Labov (1997). No original: "A clause of complicating action is a sequential clause that reports a next event in response to a potential question, "And what happened [then]?"

244 Bruner (1991, p. 12). No original: “...not every sequence of events recounted constitutes a narrative, even when it is diachronic, particular, and organized around intentional states. Some happenings do not warrant telling about and accounts of them are said to be "pointless" rather than storylike. [...]

Breaches of the canonical, like the scripts breached, are often highly conventional and are strongly influenced by narrative traditions. Such breaches are readily recognizable as familiar human plights - the betrayed wife, the cuckolded husband, the fleeced innocent, and so on. Again, they are conventional plights of readerly narratives. 


\section{Notas}

${ }^{245} \mathrm{~A}$ autoria da narrativa é de Carlos Seabra e está disponível em: https://twitter.com/microcontos. Acesso em: 02 fev. 2017.

246 Texto retirado do site http://historiasemgraca.com.br/, que, aparentemente, não armazena as informações.

247 Vargas (2011, p. 38).

${ }^{248}$ Cunha e Cintra (1985, p. 566).

2490 textos utilizados para esse levantamento foram: a) Aluisio Azevedo: Casa de pensão, A condessa Vesper e $O$ cortiço; b) Machado de Assis: A mão e a luva, Iaiá Garcia, Dom Casmurro, Memorial de Aires e Pareceres; c) Lima Barreto: Bruzundangas, Clara dos Anjos, $O$ triste fim de Policarpo Quaresma, $O$ escrivão Isaías Caminha e o Cemitério dos vivos; d) Rui Barbosa: Obras seletas (Discursos) volumes 6, 7 e 8; e e) Euclides da Cunha: Os sertões, Contrastes e confrontos e À margem da história.

250 Jakobson (s.d., p. 80-81). No original: Roughly, the encoding process goes from meaning to sound and from the lexicogrammatical to the phonological level, whereas the decoding process displays the opposite direction - from sound to meaning and from features to symbols. While a set (Einstellung) toward immediate constituents takes precedence in speech production, for speech perception the message is first a stochastic process. The probabilistic aspect of speech finds conspicuous expression in the approach of the listener to homonyms, whereas for the speaker homonymy does not exist. When saying/san/, he knows beforehand whether "sun" or "son" is meant, while the listener depends on the conditional probabilities of the context. For the receiver, the message presents many ambiguities which were unequivocal for the sender. The ambiguities of pun and poetry utilize this input property for the output. (JAKOBSON, 1960, p. 575-576)

251 Bruner (1997, p. 18).

${ }^{252}$ Castilho (1968). 
253 Ilari (1997, p. 13).

254 A expressão "espessura do presente", como a estamos usando aqui, parte das propostas de análise musical feitas Schaeffer (1966) e de Winckel (1967), que estabelecem uma duração de 50 ms. 0 músico Flo Menezes procurou definir a expressão: “... ainda que possamos distinguir sons diferentes num espaço bastante reduzido de tempo (10 ms, por exemplo), será necessário restituir o limiar temporal de discriminação dos sons, na ordem de $50 \mathrm{~ms}$, para que a ordem de aparição desses sons possa ser devidamente apreciada. A tal fenômeno dá-se o nome de densidade ou espessura do presente." (MENEZES, 2003, p. 183)

255 Vargas (2011, p. 40).

256 Retirada de Mindlin (1993).

257 Dupieux (2010). Traduzido em português como "Rubber: o pneu assassino". Agradeço ao pessoal da Chorume Humano pela indicação desse filme.

258 Claude Lévi-Strauss fez uma análise dessa figura, comparando-a com outras que aparecem em narrativas semelhantes nas sociedades americanas das mais diversas. Sua abordagem é diferente da que fazemos aqui (cf. LÉVI-STRAUSS, 2006).

259 Eco (1994, p. 53).

260 Eco (1994).

261 Eco (1994, p. 65).

262 Castilho (1968).

${ }^{263}$ Cf. Lévi-Strauss (2006).

264 Retirada de Mindlin (1991).

265 Bruner (1991, p. 11).

266 Mindlin (1993). 
267 "Dizer algo frequentemente, ou até normalmente, produzirá certos efeitos ou consequências sobre os sentimentos, pensamentos, ou ações dos ouvintes, ou de quem está falando, ou de outras pessoas. E isso pode ser feito com o propósito ou intenção de produzir tais efeitos. Em tal caso podemos dizer, então, pensando nisso, que o falante realizou um ato que pode ser descrito fazendo-se referência, meramente oblíqua, ou mesmo sem fazer referência alguma à realização do ato locucionário ou ilocucionário. Chamaremos a realização de um ato deste tipo de realização de um ato perlocucionário ou perlocução." (AUSTIN, 1990, p. 91).

268 Retirada de Silverwood-Cope (1990).

269 Retirada de Pereira (1967, p. 463).

270 Retirado de Nimuendaju (1986, p. 85).

271 Retirado de Nimuendaju (1981, p. 255).

272 Não é muito fácil localizar a origens de narrativas míticas tradicionais. No entanto, nesse caso específico podemos aventar a hipótese de se tratar de uma narrativa cuja origem seja comum à da narrativa colombiana que trata de um homem que se tornava jacaré ( $p a$ 'í em línguas da família tupi-guarani) para fazer sexo - ou somente espiar, como diz o texto abaixo - com a mulheres que se banhavam num rio: "Había un hombre al que le gustaba espiar a las mujeres mientras se bañaban en el río Magdalena. Para pasar inadvertido y verlas discretamente, decidió ir a ver a un brujo, con el objetivo de que le hiciera una pócima para convertirse en Caimán y de esta manera admirar la belleza de las mujeres, sin ser descubierto. El brujo decidió hacerle dos pócimas: una roja que lo convertía en caimán, y la blanca que lo convertía nuevamente en hombre. El hombre salió de donde el brujo junto con un amigo con quien se desplazó hasta el río, allí tomó la pócima roja y se convirtió en Caimán, Su amigo, que sostenía en su mano la pócima blanca, se asombró tanto que dejó caer unas gotas sobre él, convirtiéndolo en mitad hombre, mitad Caimán." Disponível em: 
http://www.colombia.com/colombia-info/folclor-y-tradicion es/leyendas/el-hombre-caiman/. Acesso em: 27 fev. 2017.

273 Retirado de Pereira (1967, p. 90-91).

274 Grice (1982, p. 87).

275 Castilho (1968).

276 Disponível em:

http://pt.slideshare.net/erikavecci1/contos-africanos. Acesso em: 10 mar. 2017.

277 Disponível em:

http://pt.slideshare.net/erikavecci1/contos-africanos. Acesso em: 10 mar. 2017.

278 Bueno (2017).

${ }^{279}$ Genette (1971).

280 Pañcatantra (2003, 2008, 2013).

281 Livro (2005).

282 Boccaccio (1979).

${ }^{283}$ Em Gallois (2017), pode-se ver como essa prática ainda pode se repetir como um processo instrucional. Como um processo de instrução filosófica, cf. Santos (1994).

${ }^{284}$ Bueno (2017).

285 Tradução minha. Labov (1997). No original: "The credibility of a narrative is the extent to which listeners believe that the events described actually occurred in the form described by the narrator."

286 Tradução minha. Labov (1997). No original: "Reportability is inversely correlated with credibility."

287 Vegini et al. (2014).

288 In: Sobrenatural.org. Disponível em:

http://www.sobrenatural.org/lenda_urbana/detalhar/26621 /aviso_de_mae/. Acesso em: 10 mar. 2017. 
Notas

289 In: Sobrenatural.org. Disponível em:

http://www.sobrenatural.org/relato/detalhar/27754/a_moe dinha_de_cinquenta_centavos_e_o_repelente_eletronico_sinist ro/. Acesso em: 10 mar. 2017.

290 Disponível em:

https://entrecontos.com/2017/01/28/resultados-do-

desafio-micro-contos-2017/. Acesso em: 5 out. 2017. 